\title{
EXTERNALIDADES DO CICLO PRODUTIVO DA CANA-DE-AÇÚCAR COM ÊNFASE NA PRODUÇÃO DE ENERGIA ELÉTRICA
}

Dissertação apresentada ao Programa Interunidades de Pós-Graduação em Energia da Universidade de São Paulo (Escola Politécnica / Faculdade de Economia e Administração / Instituto de Eletrotécnica e Energia / Instituto de Física) para obtenção do título de Mestre em Energia.

Orientação: Prof. Dr. José Roberto Moreira 


\section{AUTORIZO A REPRODUÇÃO E DEVULGAÇÃO TOTAL OU PARCIAL DESTE TRABALHO, POR QUALQUER MEIO CONVENCIONAL OU ELETRÔNICO, PARA FINS DE ESTUDO E PESQUISA, DESDE QUE CITADA A FONTE.}

\section{FICHA CATALOGRÁFICA}

\section{Prado, Thiago Guilherme Ferreira.}

Externalidades no ciclo produtivo da cana-de-açúcar com ênfase na geração de energia elétrica / Thiago Guilherme Ferreira Prado; Orientador: Prof. Dr. José Roberto Moreira - São Paulo, 2007.

254 p.: il.; 30 cm.

Dissertação (Mestrado - Programa Interunidades de Pós-Graduação em Energia) - EP / FEA / IEE / IF da Universidade de São Paulo.

1. Externalidades 2. Cana-de-açúcar 3. Geração de Energia Elétrica

4. Mecanismo de Desenvolvimento Limpo I. Título. 
FOLHA DE APROVAÇÃO 


\section{DEDICATÓRIA}

Dedico primeiramente a Deus pelo privilégio da vida, família, amigos e pelas oportunidades que surgiram até este momento.

“... Tudo pode parecer obstáculo quando não se consegue ver além. Portanto, abra os olhos, veja além, dedique-se, tenha fé e persevere. ...". Pai, in memorian, obrigado por tudo.

À minha admirada Mãe pelo belo exemplo de batalha, força, determinação, de amor e, principalmente, compaixão. Se estou aqui, é mérito de sua dedicação mesmo com todas as diferenças de filosofia de vida que temos.

Querida irmã, minha primeira amiga e segunda mãe, só tenho a dizer que lhe amo muito.

À família que eu pude escolher nesta vida: meus amigos.

À Maria Regina Gomes Zoby e à minha madrinha por toda a ajuda, força, carinho, atenção, conselhos e amor despendidos na fase inicial deste trabalho.

Agradeço a todos que passaram pelo meu caminho de alguma forma, pois me fazem lembrar que esta é a maior responsabilidade que temos: o destino e valor que damos às nossas próprias vidas e como nos manifestamos e fazemos presentes na existência do próximo. Por conseguinte, deixo o maior de todos os agradecimentos: a dádiva da vida e suas infinitas possibilidades, caminhos e combinações. 


\section{AGRADECIMENTOS}

Ao Prof. Dr. José Roberto Moreira por ter aceitado desenvolver este trabalho comigo, pela confiança depositada, orientação e, principalmente, pela liberdade que tive em todos os momentos.

Aos Professores do PIPGE/USP: Dr. Murilo Tadeu Werneck Fagá; Dr. Roberto Zilles; e Dr. Edmilson Moutinho dos Santos - pela oportunidade de participar do Programa Interunidades em Energia - PIPGE. À Sra. Rosa da Secretaria do PIPGE, por toda a atenção e paciência.

Aos amigos que fiz no PIPGE, em especial à Hirdan Medeiros que muito me ajudou nesta etapa final do trabalho.

À Universidade de São Paulo onde concluo mais uma etapa, por todas as oportunidades oferecidas e por todo o conhecimento nela disponibilizado. À Fundação de Amparo à Pesquisa do Estado de São Paulo por toda a estrutura, apoio e cobrança. 


\section{EPÍGRAFE}

"É melhor tentar e falhar, que preocupar-se a ver a vida passar. É melhor tentar, ainda que em vão, que sentir-se fazendo nada até o final. Eu prefiro na chuva caminhar, que em dias tristes em casa me esconder. Prefiro ser feliz, embora louco, que em conformidade viver."

\section{[Martin Luther King]}

"Pedi e vos será dado!

Procurai e encontrareis!

Batei e a porta vos será aberta!

Pois todo aquele que pede recebe,

quem procura encontra,

e a quem bate, a porta será aberta."

[Mateus 7-7-8] 


\section{RESUMO}

PRADO. T.G.F. Externalidades no ciclo produtivo da cana-de-açúcar com ênfase na geração de energia elétrica. 2007. 254p. Dissertação de mestrado - Programa Interunidades de Pós-Graduação em Energia. Universidade de São Paulo.

Este trabalho apresenta a avaliação das externalidades relativas ao ciclo produtivo da cana de açúcar, dando um enfoque para a questão da geração de energia elétrica. Os objetivos principais do estudo são realizar um levantamento e uma análise das externalidades sociais, ambientais e econômicas do ciclo produtivo da cana-de-açúcar desde sua fase inicial (período agrícola) até a conversão energética da biomassa em energia elétrica (objeto de ênfase nesse projeto). Repartindo os impactos, quando possível nos subsistemas elaborados a partir da análise do ciclo produtivo do setor, cujos resultados de uma forma geral eram até então conhecidos, mas nunca segregados e tratados de forma integrada sob a ótica de avaliação das externalidades relacionadas à atividade de produção. A geração de eletricidade excedente traz consigo externalidades positivas e negativas. Elas envolvem aspectos prejudiciais sob a ótica das emissões atmosféricas sobre a saúde humana e o meio biótico; positivo, mediante a utilização de fontes renováveis para geração de eletricidade provendo o deslocamento de derivados do petróleo tanto para geração de energia térmica quanto de elétrica, reduzindo assim o consumo de combustíveis fósseis que são os principais componentes fomentadores da acentuação do efeito estufa; além dos benefícios associados à geração distribuída, discutidos neste trabalho. Ambas qualificam esta forma de geração dentro dos requisitos do mecanismo de desenvolvimento limpo, que será avaliado com a visão de ser um instrumento para internalizar o benefício de gerar energia com recursos renováveis. Dos impactos avaliados correspondentes ao ciclo produtivo da cana-de-açúcar, 32,68 \% estão associados com a etapa de geração de eletricidade. Os principais impactos e efeitos avaliados na etapa qualitativa e quantitativa deste trabalho nas externalidades de produção foram ratificadas como efeitos predominantes também nas externalidades avaliadas via simulação computacional (ECOSENSE LE) do projeto ExternE.

Palavras-chave: externalidades, cana-de-açúcar, geração de energia elétrica, mecanismo de desenvolvimento limpo. 


\begin{abstract}
PRADO. T.G.F. Externalidades no ciclo produtivo da cana-de-açúcar com ênfase na geração de energia elétrica. 2007. 254 p. Work - Program of Post-Graduation in Energy. University of São Paulo.

This work presents the evaluation of externalidades in production from sugarcane life cycle, with emphasis at electric power generation. The main objective of this study is to assess the health, social, environmental and economical externalities related with the production process of sugarcane industry from the start point of the productive chain (agricultural period) until the energy conversion of the biomass in electric power (main emphasis). Distributing the impacts, when possible, in subsystems that main productive cycle were divided, whose results, in general, were known but never segregated and treated by an integrated view under the optics of externalities evaluation at the production activity chain at sugarcane sector. The surplus generation of electricity brings with itself positive and negative externalities. The negative ones involve harmful aspects under the atmospheric emissions and human health and the biotic environment; as positive ones, are the use of renewable sources for electricity generation providing displacement of fossil fuels and indirectly thermal and electrical energy, reducing the consumption of this kind of fuels that are the main promoting components from the accentuation of the greenhouse effect and the benefits associated to the distributed generation, also discussed in this work. Both of these positive aspects, qualify this form of generation to participate at the clean development mechanism, that it will be treated as an instrument for incorporate the benefit of generating energy with renewable resources. From the main productive chain impacts related to the life cycle of the sugarcane, $32,68 \%$ are associated with the stage of electricity generation. The main impacts assessed in the qualitative and quantitative way as production externalities were confirm as predominant effects also using the computational simulation tool (ECOSENSE LE) from the ExternE project.
\end{abstract}

Keywords: externalities, sugarcane, electrical power generation, clean development mechanism. 


\section{LISTA DE ILUSTRAÇÕES}

Figura 2.1 - Evolução da carga própria em [ $\left.\mathrm{MW}_{\text {med }}\right]$ para o período de 2001 à 2005

Figura 2.2 - Estrutura da Capacidade Instalada no SIN - [MW]

Figura 2.3 - Alternativas tecnológicas para geração de eletricidade a partir de biomassa

Figura 2.4 - Participação por região na geração de eletricidade e capacidade instalada

Figura 2.5 - Distribuição da autogeração de eletricidade no Brasil por setores da economia 17

Figura 2.6 - Produção de cana-de-açúcar no Brasil, regiões centro-sul, norte-nordeste e

Estado de São Paulo

Figura 2.7 - Produção de açúcar no Brasil, regiões centro-sul, norte-nordeste e Estado de São

Paulo

Figura 2.8 - Produção de álcool no Brasil, regiões centro-sul, norte-nordeste e Estado de São

Paulo

Figura 3.1. Número de atividades de projeto no sistema do MDL

Figura 3.2. Total de Atividades de Projeto MDL no Mundo

Figura 3.3. Capacidade instalada [MW] das atividades de projeto aprovadas

Figura 3.4. Limites do Projeto - delimitação dos sistemas envolvidos sob o aspecto da geração de eletricidade

Figura 3.5. Diagrama esquemático das formas de quantificação dos fatores de emissão envolvidos na avaliação do cenário de linha de base

Figura 3.6. Exemplo de fuga com base na indisponibilidade no mercado local de bagaço devida à atividade

Figura 4.1. Fluxograma simplificado do processo industrial do álcool etílico hidratado

Figura 4.2. Sistemas do ciclo produtivo 
Figura 5.9. Variação das opções metodológicas de avaliação das externalidades ao longo do tempo

Figura 6.2. Mapa de fauna ameaçada de extinção - específico de aves - do Estado de São

Paulo

Figura 6.3. Mapa de fauna ameaçada de extinção - contendo demais animais - do Estado de São Paulo

Figura 6.4. Áreas de preservação e interesse ambiental dentro do Estado de São Paulo

Figura 6.5. Biomas do Estado de São Paulo

Figura 6.6. Mapa do potencial agrícola do Estado de São Paulo

Figura 6.7. Área total de pastagem. Período: 2000 - 2006

Figura 6.8. Mapa dos remanescentes florestais do Estado de São Paulo

Figura 6.9. Classificação dos 40 Escritórios de Desenvolvimento Rural (EDRs), por Faixa de Valor de Produção e Classificação das Principais Atividades Agropecuárias nos EDRs, Estado de São Paulo 


\section{LISTA DE TABELAS}

Tabela 2.1. Geração de eletricidade por fonte de energia [GWh]

Tabela 2.2. Geração de Energia Elétrica por Estado [GWh]

Tabela 2.3. Participação de cada Unidade da Federação no Total de Autoprodução de Eletricidade no Brasil [GWh]

Tabela 2.4. Evolução da produção da Energia Primária

Tabela 2.5. Relação entre produção e consumo de energia final

Tabela 2.6. Relação das UTEs em expansão à base de biomassa

Tabela 2.7. Resultados gerais do PROINFA - Etapa I

Tabela 2.8. Participação por Estado no PROINFA, fonte biomassa

Tabela 3.1. Principais características dos fatores de emissão para determinação do cenário da linha de base

Tabela 3.2. Principais características dos fatores de emissão para determinação do cenário da linha de base

Tabela 4.1. Componentes do mecanismo ambiental pela Exergia

Tabela 4.2. Componentes do mecanismo ambiental pela Emergia

Tabela 4.3. Breve comparativo entre Energia, Exergia e Emergia

Tabela 4.4. - Quantidade de substâncias atmosféricas emitidas por tonelada de álcool. Incluído o $\mathrm{CO}_{2}$ emitido pela queimada e pela geração de vapor e eletricidade

Tabela 4.5. - Porcentagem das maiores emissões atmosféricas do ciclo de vida do álcool considerando o $\mathrm{CO}_{2}$ da queimada e do uso do energético do bagaço

Tabela 4.6. - Porcentagem das maiores emissões atmosféricas do ciclo de vida do álcool desconsiderando o $\mathrm{CO}_{2}$ da queimada da palha, do uso energético do bagaço, da fermentação e utilização do álcool 
Tabela 4.8. - Consumo de recursos não-renováveis 96

Tabela 4.9. - Consumo de energia 97

Tabela 4.10. - Potencial de aquecimento global 97

Tabela 4.11. - Potencial de formação de ozônio troposférico 98

Tabela 4.12. - Potencial de acidificação 99

Tabela 4.13. - Potencial de eutrofização 99

Tabela 4.14. - Potencial de ecotoxicidade 100

Tabela 4.15. - Potencial de toxicidade humana 101

Tabela 5.1. Análise comparativa de metodologias de avaliação de externalidades $\quad 122$

Tabela 5.2. Levantamento dos estudos de externalidades na geração de eletricidade $\quad 127$

$\begin{array}{ll}\text { Tabela 6.1. Compilação dos resultados } & 138\end{array}$

Tabela 6.2. Externalidades levantadas nas atividades 1, 2 e $3 \quad 142$

$\begin{array}{ll}\text { Tabela 6.3. Externalidades levantadas na atividade } 4 & 147\end{array}$

Tabela 6.4. Externalidades levantadas na atividade $6 \quad 155$

Tabela 6.5. Valoração das externalidades relacionadas com o efeito estufa 157

Tabela 6.6. Valoração das externalidades por categoria de impacto 157

Tabela 6.7. Valoração das externalidades por substância emitida $\quad 157$

Tabela 6.8. Externalidades levantadas na atividade $7 \quad 161$

Tabela 6.9. Reflexos da mudança para o sistema de colheita de cana crua sobre as principais regiões canavieiras do Estado de São Paulo 174 


\section{LISTA DE ABREVIATURAS E SIGLAS}

ACL - Ambiente de Contratação Livre

ACV - Avaliação do Ciclo de Vida

ANEEL - Agencia Nacional de Energia Elétrica

BEN - Balanço Energético Nacional

BESP - Balanço Energético do Estado de São Paulo

CEAL - Companhia Energética de Alagoas

CEMAT - Centrais Elétricas Mato-grossenses S.A.

CEMIG - Companhia Energética de Minas Gerais

CETESB - Companhia de Tecnologia de Saneamento Ambiental

CIMGC - Comissão Interministerial de Mudança Global do Clima

CNTP - Condições Normais de Temperatura e Pressão

CONAMA - Conselho Nacional do Meio Ambiente

CQNUMC - Convenção Quadro das Nações Unidas de Mudanças Climáticas

COPERSUCAR - Cooperativa de Produtores de Cana-de-açúcar, Açúcar e Álcool do Estado de São Paulo

EDIP - Environmental Development of Industrial Products

EDR - Escritório de Desenvolvimento Rural

EE - Energia Elétrica

EESC - Escola de Engenharia de São Carlos

E\&P - Exploração e Produção de Gás Natural, Petróleo e seus de derivados

ELETROBRAS - Centrais Elétricas Brasileiras S.A.

EPE - Empresa de Pesquisa Energética

EU - União Européia

GASBOL - Gasoduto Brasil - Bolívia

GD - Geração Distribuída

GEE - Gases de Efeito Estufa 
GN - Gás Natural

GWP - Global Warming Potential

IPCC - Intergovernmental Panel on Climate Change

MMA - Ministério do Meio Ambiente

MME - Ministério de Minas e Energia

OC - Óleo Combustível

ONS - Operador Nacional do Sistema

$\mathrm{PCH}$ - Pequenas Centrais Hidrelétricas

PDEE - Plano Decenal de Expansão de Energia Elétrica

PIA - Produto Independente Autônomo

PPA - Power Purchase Agreement - Contrato de venda de energia

PROINFA - Programa de Incentivo às Fontes Alternativas de Energia Elétrica

RCE - Redução Certificada de Emissão

SIN - Sistema Interligado Nacional

TIR - Taxa Interna de Retorno

UNICA - União da Agroindústria Canavieira de São Paulo

UNFCC - United Nations Framework Convention on Climate Change

USP - Universidade de São Paulo

UTE - Usina Termelétrica

VE - Valor Econômico

VR - Valor Referência 
1. INTRODUÇÃO.

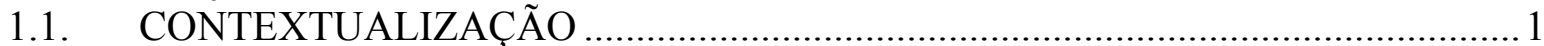

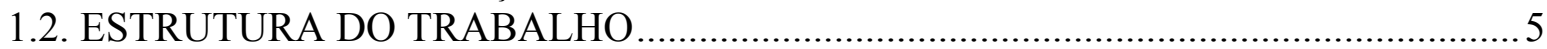

2. ENERGIA ELÉTRICA E O SETOR SUCROALCOOLEIRO NO ESTADO DE SÃO PAULO.

2.1. GERAÇÃO DE ENERGIA COM BIOMASSA ……………………………………...... 11

2.2. REPRESENTATIVIDADE DO SETOR NA MATRIZ ENERGÉTICA........................14

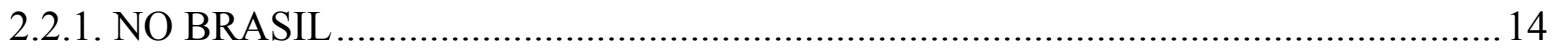

2.2.2. NO ESTADO DE SÃO PAULO............................................................................ 18

2.2.3. CONTEXTUALIZAÇÃO DESSE APROVEITAMENTO NO PLANEJAMENTO ENERGÉTICO

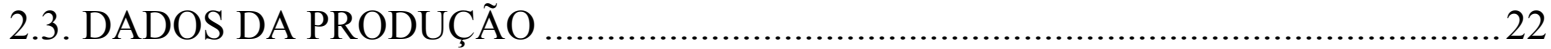

2.3.1. CENÁRIO NACIONAL E DO ESTADO DE SÃO PAULO ………………............23

2.4. INSTRUMENTOS DE INCENTIVO À GERAÇÃO DE ELETRICIDADE A PARTIR

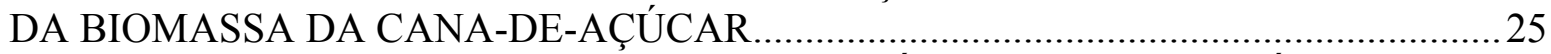

2.4.1. INCENTIVO NO ARCABOUÇO REGULATÓRIO DO SETOR ELÉTRICO .........26

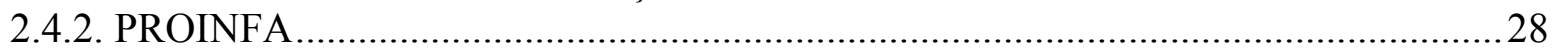

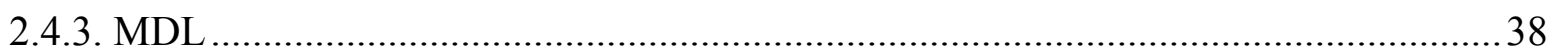

3. A INDÚSTRIA SUCROALCOOLEIRA E O MECANISMO DE DESENVOLVIMENTO

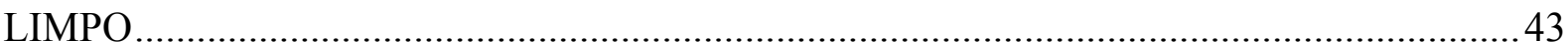

3.1. PARTICIPAÇÃO DE EMPREENDIMENTOS COM BASE NA BIOMASSA DA

CANA-DE-AÇÚCAR NO BRASIL ............................................................................ 45

3.2. METODOLOGIAS QUANTITATIVAS PARA AVALIAÇÃO DE PROJETOS MDL COM ÊNFASE NO SETOR SUCROALCOOLEIRO ………………………………..........46

3.2.1. METODOLOGIAS APROVADAS ATUALMENTE ………………………...........46

3.2.2. DESENVOLVIMENTO DAS METODOLOGIAS................................................. 48

3.2.2.1. CORPO COMUM ÀS METODOLOGIAS ………………........................................4

3.2.2.2. METODOLOGIA - BAGAÇO \& RESÍDUOS DE BIOMASSA ............................49

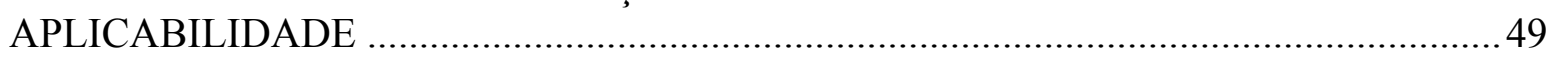

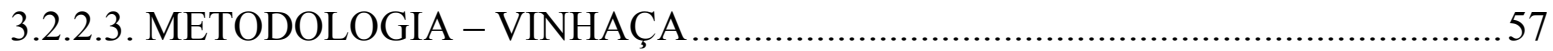

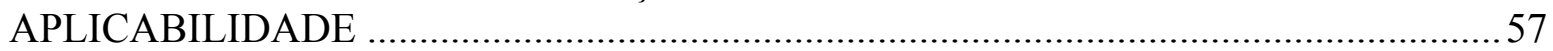

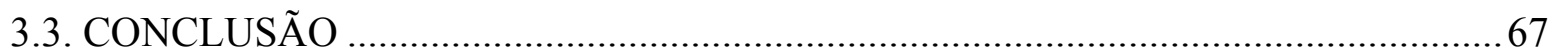

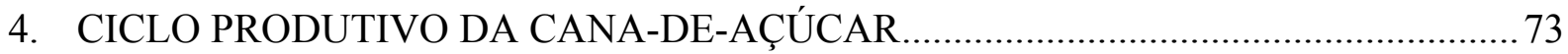

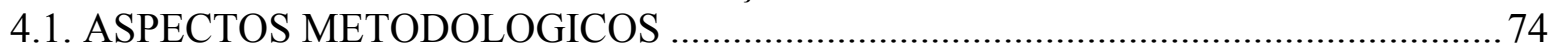

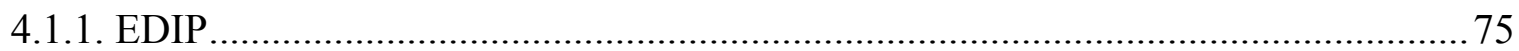

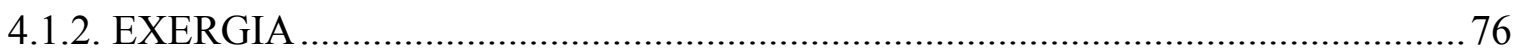

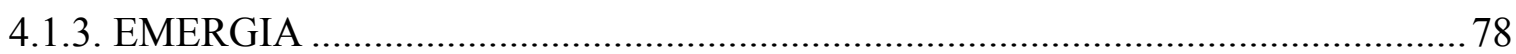

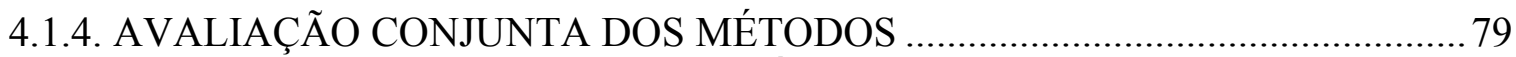

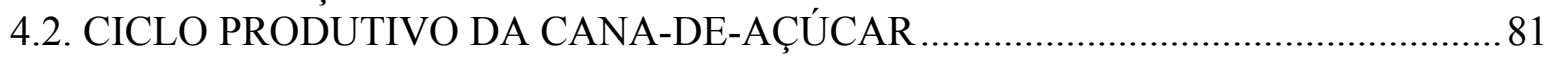

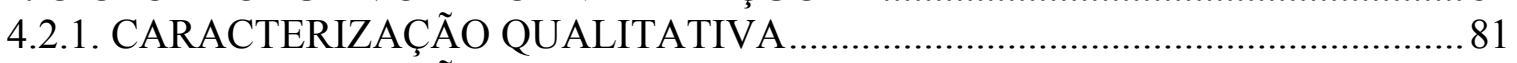

4.2.2. CARACTERIZAÇÃO QUANTITATIVA ............................................................ 89

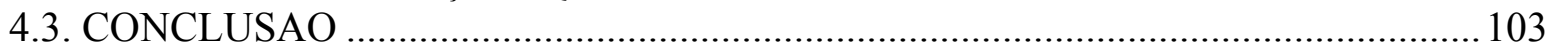

5. EXTERNALIDADES - CONCEITOS E MÉTODOS DE AVALIAÇÃO E

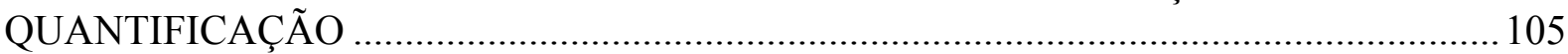

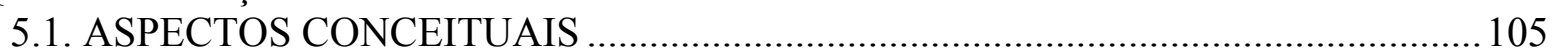

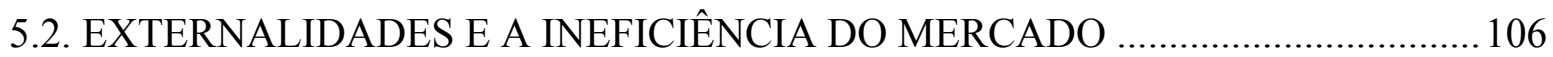

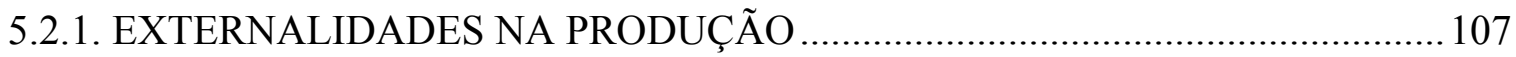

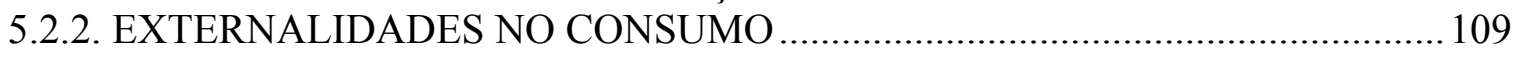


5.3. SOLUÇÕES PRIVADAS PARA EXTERNALIDADES ........................................... 110

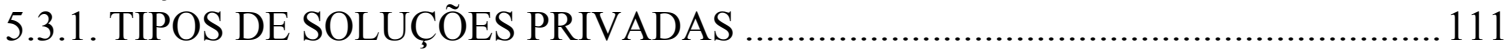

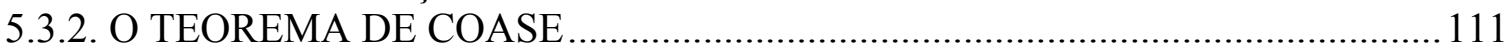

5.3.3. PORQUE SOLUÇÕES PRIVADAS NÃO FUNCIONAM SEMPRE .................. 111

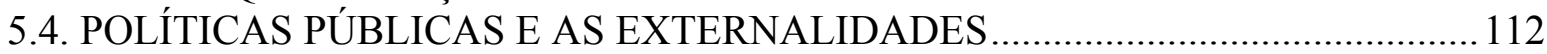

5.4.1. POLÍTICAS DE COMANDO E CONTROLE ................................................... 112

5.4.2. POLÍTICAS BASEADAS NO MERCADO ..................................................... 114

5.4.3. VANTAGENS E DESVANTAGENS DAS POLÍTICAS PÚBLICAS NAS

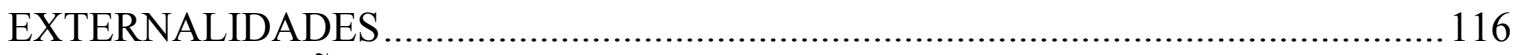

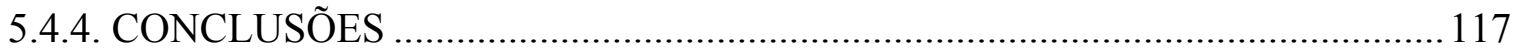

5.5. COMPLEMENTADO OS ASPECTOS CONCEITUAIS ......................................... 118

5.6. METODOS DE AVALIAÇÃO E QUANTIFICAÇÃO DAS EXTERNALIDADES NO

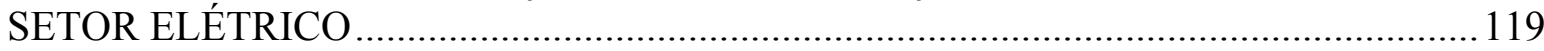

5.6.1. EXTERNALIDADES NA GERAÇÃO DE ENERGIA - LEVANTAMENTO

BIBLIOGRÁFICO ............................................................................................. 125

5.6.2. PRINCIPAIS EXTERNALIDADES APONTADAS PARA A FONTE

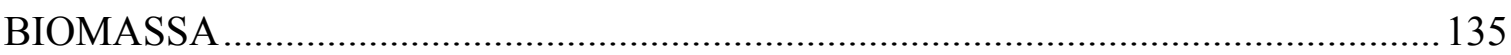

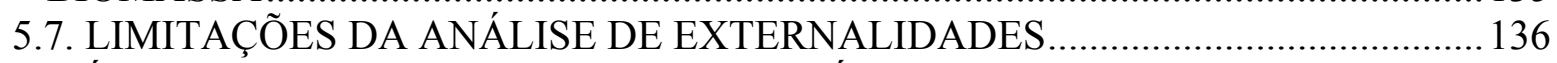

6. ANÁLISES DE EXTERNALIDADES DA INDÚSTRIA SUCROALCOOLEIRA E

PROPOSTAS PARA INTERNALIZAÇÃO......................................................................... 137

6.1. EXTERNALIDADES ASSOCIADAS DIRETAMENTE AO ASPECTO DO CICLO

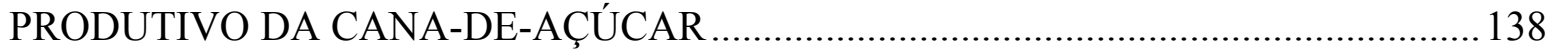

6.2 EXTERNALIDADES - OUTROS ASPECTOS NO SETOR SUCROALCOOLEIRO

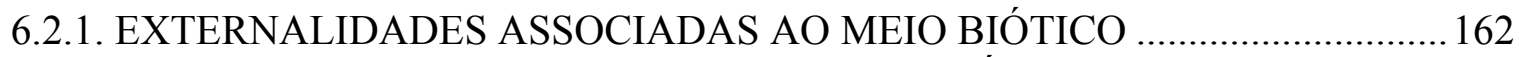

6.2.2. EXTERNALIDADES ASSOCIADAS AO MEIO FÍSICO ................................ 171

6.2.3. EXTERNALIDADES ASSOCIADAS AO MEIO SOCIOECONÔMICO ........... 172

7. CONCLUSÕES .................................................................................................. 177

ANEXO A - COGERAÇÃO - TECNOLOGIAS E ASPECTOS TÉCNICOS NA GERAÇÃO

DE ELETRICIDADE A PARTIR DA BIOMASSA ….................................................. 198

ANEXO B - METODOLOGIA DE CÁLCULO DO FATOR DE EMISSÃO DE USINAS

GERADORAS DE ELETRICIDADE CONECTADAS AO SISTEMA INTERLIGADO ...215

ANEXO C - METODOLOGIA DO PROJETO ExternE - EXTERNALITIES OF ENERGY 226 


\section{INTRODUÇÃO}

\subsection{CONTEXTUALIZAÇÃO}

Considerando a história e as transformações que a humanidade constantemente sofre, a energia tem desempenhado um papel fundamental. No Brasil, como no restante do mundo, a energia é um importante vetor para o desenvolvimento. Contudo, a preocupação com os impactos no meio ambiente e na sociedade deve fazer parte da política, do planejamento e da execução dos programas de curto, médio e longo prazo do setor energético de forma a garantir que esse desenvolvimento seja sustentável. Deste modo, surge uma nova componente a ser considerada pelas empresas responsáveis pelo parque de geração de eletricidade: a relação entre a energia elétrica, o meio ambiente e a sociedade.

Um conhecimento aprofundado das questões energéticas, sociais, legais e, principalmente, das ambientais levando em conta as inovações técnicas são requisitos imperativos a fim de sustentar um ciclo de desenvolvimento econômico capaz de considerar e respeitar a velocidade de resposta e a capacidade de suporte do meio ambiente e da própria sociedade.

A crise do setor elétrico brasileiro em 2001 confirmou o déficit da oferta de eletricidade e a ausência de novos empreendimentos como linhas de transmissão, usinas hidrelétricas, termelétricas, aproveitamento de fontes renováveis de energia e a utilidade do aumento da geração de energia elétrica através da cogeração. Dentro do contexto desta última, o setor sucroalcooleiro tem apresentado um grande potencial de geração de energia, apresentando atrativos econômicos e ambientais, devido, principalmente, à utilização do bagaço da cana-deaçúcar como combustível. Mesmo para os arranjos mais comuns, operando desde ciclos a vapor mais simples aos sistemas mais avançados, a recuperação de energia através da integração térmica e a redução do consumo de vapor de processos são fatores de grande influência para aumento da eficiência e de excedentes de energia nas plantas de produção deste setor. 
Atualmente, o Brasil colhe aproximadamente 450 milhões de toneladas de cana-de-açúcar por ano, fato este que o torna o maior produtor mundial deste produto, segundo a União de Indústrias de Cana-de-Açúcar (ÚNICA). Na maioria dos casos, a safra é metade destinada à produção de açúcar e a outra metade à de etanol.

Existem aproximadamente 310 usinas de álcool e açúcar no país e o estado de São Paulo responde por 130 dessas instalações. Sendo possível utilizar o bagaço da cana-de-açúcar para geração de energia (térmica / mecânica / elétrica) através da cogeração.

O setor sucroalcooleiro tem características que o distinguem dos outros segmentos de cogeração no país. Em primeiro lugar, é considerado como auto-suficiente em termos de geração de energia elétrica para consumo próprio. Isso porque a grande maioria das usinas de açúcar e álcool produzem a eletricidade que é consumida nos seus processos. Em segundo lugar, é o setor que tem maiores expectativas quanto à geração de excedentes de energia.

Por exemplo, segundo dados da CPFL - Companhia Paulista de Força e Luz, no ano de 2000, essa empresa negociou 34,5 MW em excedentes de eletricidade com as usinas sucroalcooleiras paulistas. E a potência negociada evoluiu ao longo dos anos: em 2001, esse número chegou a 85,0 MW; 2002 para 150,0 MW; 2003 para 279,7 MW (Xavier Filho, B.J., CPFL, comunicação pessoal, APUD Brighenti, 2003); 2004 para 330,0 MW e, por fim, em 2005 para 337,0 MW (CPFL, 2005).

$\mathrm{Na}$ questão ambiental, a cana-de-açúcar é uma fonte renovável de energia. Pode gerar eletricidade, com o balanço da emissão de dióxido de carbono quase nulo quando comparado com combustíveis convencionais tendo, portanto, um impacto ambiental inferior, principalmente em relação aos combustíveis fósseis.

Os estudos tradicionais onde se analisam processos de conversão energética, normalmente, limitam-se a questões técnicas e econômicas sem considerar os aspectos ambientais e sociais. A cogeração de energia na indústria sucroalcooleira é uma alternativa viável de produção de excedente de energia elétrica além das vantagens no âmbito ambiental e social.

O potencial para exploração dos recursos hídricos destinados à geração de energia elétrica no Estado de São Paulo é baixo se considerada a entrada e funcionamento das atuais hidrelétricas em construção. Este Estado é responsável por, aproximadamente, um terço de toda a energia consumida no país, caracterizando-se como um grande importador para outros estados. Por 
outro lado, é responsável por mais de $60 \%$ da biomassa proveniente do bagaço, sendo que este potencial poderá ser explorado pela iniciativa privada para aumentar a geração de excedente de energia elétrica, podendo não demandar recursos públicos. Deve-se destacar, ainda, o fato da colheita da cana-de-açúcar ocorrer no período de menor disponibilidade hídrica, quando um melhor aproveitamento do bagaço gerado pela indústria de processamento de cana poderia gerar um excedente de energia elétrica. A eletricidade pode ser vendida às concessionárias, contribuindo para a manutenção dos níveis dos reservatórios das barragens.

A avaliação dos custos ambientais parte de estudos existentes para processos convencionais de geração de eletricidade, iniciou-se tanto nos Estados Unidos (Ottinger, 1991), como na Europa e no Brasil (Furtado, 1996), com o projeto ExternE - Externalities of Energy (EC, 1995), como parte de um estudo conjunto entre Comissão Européia e o Departamento e Energia dos Estados Unidos (DOE). Estas avaliações visaram desenvolver metodologias para avaliação dos custos ambientais (externalidades) para um conjunto de combustíveis (ciclo total).

As externalidades do ciclo de um combustível na geração de eletricidade são os custos impostos à sociedade e ao meio-ambiente que não foram considerados pelos produtores e consumidores de energia, isto é, que não estão incluídos no preço de mercado por ser resultado de uma avaliação econômica tradicional.

Deixar de internalizar a valoração das externalidades significa, indiretamente, considerar que o meio-ambiente e a sociedade não têm valor algum. Deste modo, é mais adequado adotar um sistema que seja capaz de avaliar as externalidades, considerando suas imprecisões do que apenas ignorá-las.

O Mecanismo de Desenvolvimento Limpo (MDL) permite que os países desenvolvidos realizem investimentos em projetos que variam desde reflorestamentos, substituição de combustíveis, uso final da energia, eficiência energética até a inserção de formas de geração de energia renováveis nos países em desenvolvimento. Em troca, essas nações investidoras recebem créditos de carbono que contabilizarão para atingir a suas metas internas estabelecidas pelo Protocolo de Quioto.

O MDL além de procurar a redução da emissão dos gases de efeito estufa visa instigar o desenvolvimento sustentável nos países em desenvolvimento. Dentro deste contexto, o termo sustentável, neste projeto, se relaciona a critérios sociais, ambientais e econômicos que 
permitam analisar as interferências da cadeia produtiva da cana-de-açúcar e de seus derivados, ao longo do tempo.

Apesar do Brasil não estar obrigado a reduzir suas emissões de dióxido de carbono e metano, por ser um país em desenvolvimento, existem setores que podem ser explorados de modo que possam oferecer um proveito do mercado de créditos de carbono, previsto pelo MDL.

O estudo do cultivo de biomassa, especificamente de cana-de-açúcar, para fins de produção de energia sob a ótica do Mecanismo de Desenvolvimento Limpo, pode permitir posicionar o Brasil numa posição estratégica e privilegiada no cenário mundial. Vantagens ambientais e climáticas estão presentes, tais como: vasta área de solo fértil, insolação abundante e recursos hidrológicos que compõem o cenário ideal para a absorção e armazenamento da energia solar nos produtos da cana-de-açúcar. Este armazenamento de energia renovável e a sua possível conversão em energia garantem ao país uma alternativa de fornecimento energético aos combustíveis fósseis. Esses, num médio prazo, tendem a reduzir a sua participação no mercado quando os seus impactos devido ao seu uso em larga escala forem contabilizados e, entendidos pela população, fato este, que já está sendo analisado em alguns países (EC, 1995). Uma vez que, são conhecidas as vantagens da utilização da biomassa quando comparada aos combustíveis fósseis, elas devem ser contempladas na análise.

Comparando sob o ponto de vista econômico tradicional os combustíveis fósseis e a biomassa, no âmbito da geração de energia elétrica, a biomassa parece ainda não ser competitiva o suficiente. Tal fato, a princípio, deixou de ser verdade nos últimos 2 anos no Brasil. Fontes de energia renováveis precisam competir economicamente com as fontes tradicionais para poder ocupar uma fração significativa do mercado e o MDL pode auxiliar nessa melhora de competitividade.

Essa visão econômica não contempla diretamente os custos ambientais, tão pouco os benefícios que a energia renovável representa. As externalidades podem ser valoradas e quantificadas e a integração desses custos permite uma avaliação econômica adequada que, juntamente com o MDL, abre a possibilidade de definição de políticas que possam tornar fontes de energia renováveis mais competitivas ambientalmente e socialmente.

A análise das externalidades do ciclo de vida da cana-de-açúcar irá fornecer subsídios imperativos quanto à sustentabilidade da utilização da energia proveniente da biomassa e no 
que tange aos impactos positivos e negativos na indústria sucroalcooleira tanto para o Estado de São Paulo quanto ao território nacional.

A quantificação das externalidades relacionadas a qualquer setor da economia exige, de fato, um amplo posicionamento considerando que diversas áreas estão abarcadas, envolvendo não só o setor privado como, também, o governamental através das políticas públicas sobre a área de interesse. Para o caso selecionado, o setor sucroalcooleiro, a valoração transcende a questão energética e envolve a questão ambiental, social e econômica para o Estado de São Paulo pela expressividade desse setor na economia. Portanto, a verificação da sustentabilidade deste setor produtivo se torna relevante ao estudo em questão.

Devido a essa grande importância para o cenário de geração de energia e do potencial existente no Estado de São Paulo e no País, foram selecionados diversos trabalhos ao longo do levantamento bibliográfico deste trabalho que objetivavam avaliar, quantificar e propor formas de internalização dos custos externos para avaliação das opções existentes de geração de eletricidade. Esses estudos, também, proporcionaram um melhor entendimento das características, o comportamento e a dinâmica das externalidades sob a ótica da geração de eletricidade.

\subsection{ESTRUTURA DO TRABALHO}

Esta dissertação tem como objetivo realizar um levantamento e uma análise das externalidades sociais, ambientais e econômicas do ciclo produtivo da cana-de-açúcar e seus derivados desde sua fase inicial (período agrícola) até a conversão energética da biomassa em energia elétrica (objeto de ênfase nesse projeto). Repartem-se os impactos, quando possível nos subsistemas elaborados a partida da análise do ciclo produtivo do setor.

Neste contexto, a presente pesquisa aborda desde o balanço energético nacional até o ciclo produtivo do setor sucroalcooleiro com ênfase na geração de eletricidade excedente. Esta abordagem transcende para a discussão do arcabouço conceitual das externalidades e suas metodologias de avaliação e quantificação frisando em especial o setor de infra-estrutura de energia elétrica. A questão das mudanças climáticas também é vista, com um breve descritivo 
do Protocolo de Quioto donde se selecionou o MDL como um mecanismo relevante para o objeto em estudo, considerando o potencial do setor sucroalcooleiro.

A dissertação está dividida em sete capítulos para apresentar, de forma seqüencial, o desenvolvimento do estudo. O Capítulo 1 é a introdução do trabalho e apresenta o contexto geral e a motivação na qual se insere o estudo. No Capítulo 2, é apresentada uma análise sob a perspectiva energética, a participação setor sucroalcooleiro na matriz energética do país e estadual.

No capítulo seguinte, o Capítulo 3, é apresentado um breve sumário do Protocolo de Quioto de onde se destaca o Mecanismo de Desenvolvimento Limpo. Ao mesmo tempo são expostos dados oficiais de projetos dentro do âmbito do MDL envolvendo o setor sucroalcooleiro. Por fim, a metodologia de quantificação de créditos de carbono é discutida tanto para o aproveitamento eletroenergético do bagaço da cana quanto da possibilidade do mesmo aproveitamento proveniente da vinhaça.

O Capítulo 4 apresenta o ciclo produtivo da cana-de-açúcar. Este capítulo é essencial, pois apresenta o sistema a ser considerado na avaliação das externalidades delimitando a área e os subsistemas de estudo.

O Capítulo 5 detalha o cerne do objeto do estudo, que é a conceituação das externalidades e seus métodos de avaliação e quantificação destacando estudos e métodos mais aplicáveis ao setor de geração de energia elétrica.

O Capítulo 6 apresenta os resultados obtidos na dissertação tendo como base as técnicas e conceitos alavancados no Capítulo 5, os subsistemas apresentados no Capítulo 4 considerando, inclusive, a internalização quando considerada a questão das mudanças climáticas via MDL - assunto este debatido no Capítulo 3.

Por fim, o Capítulo 7 expõe as conclusões deste estudo e sugestões para trabalhos futuros. Neste trabalho, os Anexos foram elaborados de forma a complementar e servir como material de apoio ao conteúdo dos capítulos de 2 a 6. 


\section{ENERGIA ELÉTRICA E O SETOR SUCROALCOOLEIRO NO ESTADO DE SÃO PAULO}

Este capítulo tem como objetivo a contextualização do setor sucroalcooleiro no contexto energético ${ }^{1}$. No entanto, para efeitos comparativos, parte-se de uma perspectiva macro energética (nacional), regional energética (Estado de São Paulo) ${ }^{2}$ e pontual (desde a atividade produtiva da usina de cana-de-açúcar até a geração de eletricidade); este último será visto num capítulo a parte. Deste modo, destaca-se o potencial da agroindústria da cana no contexto Nacional e Estadual, numa das áreas estratégicas para o desenvolvimento do país: a infraestrutura de energia.

Esta abordagem é necessária, pois ao se tratar desta questão - em especial a geração de energia elétrica - torna-se impossível uma abordagem e análise isoladas do assunto. Os efeitos decorrentes da geração distribuída de eletricidade com base na biomassa proveniente da cana-de-açúcar podem interferir no comportamento do Sistema Interligado Nacional (SIN), das concessionárias de serviços de energia elétrica presentes no Estado de São Paulo e, também, nas regiões onde a indústria sucroalcooleira se faz presente.

Contudo, a demanda e a escassez de energia se converteram em um tema central tanto no cenário nacional (vide como exemplo a crise energética ocorrida no Brasil em 2001 e seus desdobramentos sob formas de políticas, marcos regulatórios e programas), quanto no cenário internacional $^{3}$. O consumo de energia cresce, mas ao mesmo tempo constata-se a limitação dos recursos naturais.

Atualmente, com relação à demanda de eletricidade para região Sudeste/Centro-Oeste (SE/CO) houve um incremento médio de 2,53 \%, valor este calculado de Janeiro à Setembro num comparativo entre os anos de 2005 e 2006.

\footnotetext{
${ }^{1}$ No que se refere à energia elétrica.

${ }^{2}$ Considerando que o Estado de São Paulo é objetivo de análise desta pesquisa.

${ }^{3}$ Como por exemplo: nacionalização das atividades de E\&P na Bolívia e desdobramentos no Brasil pela dependência do Gás Natural (GN) transportado pelo Gasoduto Brasil-Bolívia (GASBOL); dependência da União Européia do GN fornecido pela Rússia; retomada lenta da atividade de geração de eletricidade a partir de centrais nucleares (Guterl, 2006); investimentos em formas renováveis de geração de eletricidade (Guterl, 2006).
} 
Realizando uma breve análise do conteúdo da Figura 2.1. que versa sobre a evolução da carga própria das regiões Sudeste e Centro-Oeste, percebe-se claramente o efeito do racionamento sobre o comportamento da carga no país. Somente em meados de agosto e setembro de 2004, a carga superou o pico ocorrido em março de 2001. Contudo, considerando os anos de 2004, 2005 e os incrementos positivos já ocorridos em 2006, a tendência de retomada da demanda de eletricidade já é um fato considerado no planejamento energético do país.

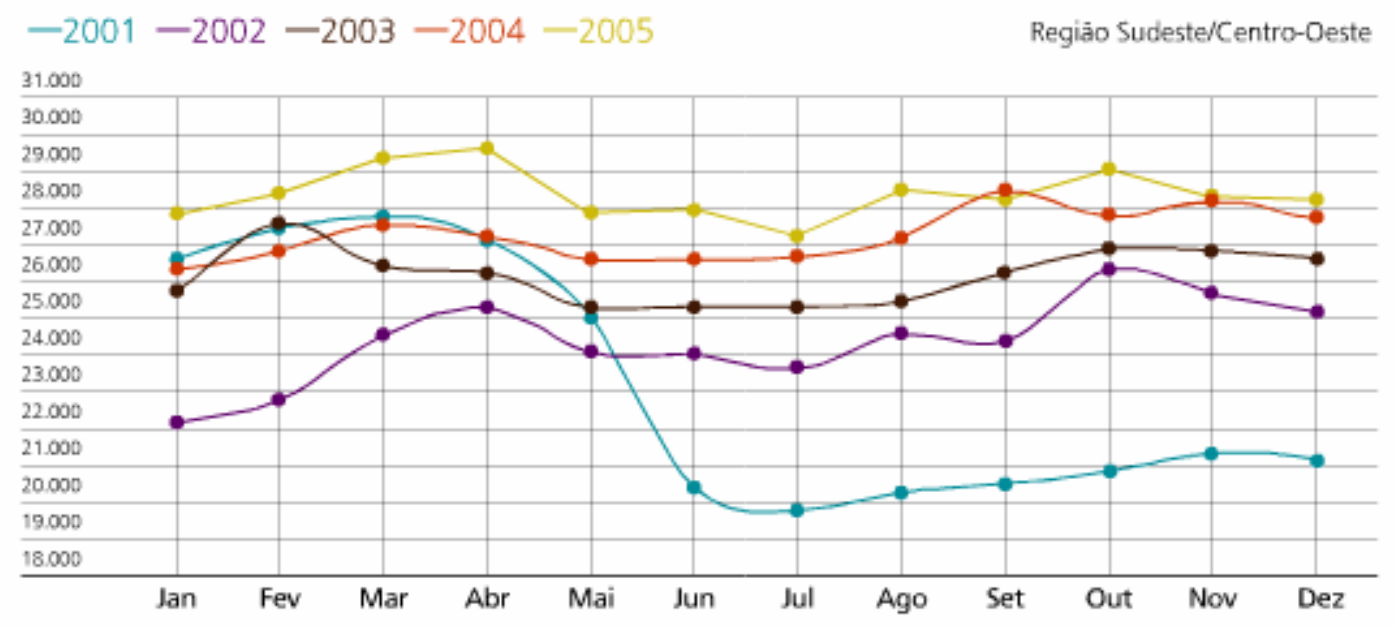

Figura 2.1. Evolução da carga própria em $M W_{\text {med }}$ para o período de 2001 à 2005 Fonte: ONS

Tal fato se comprova visto que segundo a Empresa de Pesquisa Energética - EPE, no Plano Decenal 2006-2015, o consumo total de energia em $\mathrm{TW}_{\text {med }}$ nos cenários de referência alta, médio e baixa apresentam um incremento entre 2005-2010 de 5,6 \%, 5,3\% e 4,4\% ao ano respectivamente.

Do mesmo modo que as projeções do consumo de eletricidade são ferramentas que auxiliam no processo de planejamento, o potencial de conservação e as perspectivas de aumento na eficiência energética devem ser considerados na avaliação da situação energética do País. $\mathrm{O}$ racionamento de 2001-2002 e o comportamento das curvas de carga subseqüentes servem como exemplo do potencial das medidas de conservação incorporadas pelos agentes de consumo $^{4}$ e a retração na evolução da carga no mercado. Novamente, o Plano Decenal 20062015, indica que ainda existe espaço para um potencial de conservação significativo. $O$ quantitativo total de energia elétrica previsto a ser conservado até o ano 2015, considerando

\footnotetext{
${ }^{4}$ Esta afirmação não significa que a redução da carga percebida na Figura 2.1. deve-se, somente, a medidas de conservação. O comportamento apresentado pela curva é um desdobramento do racionamento de energia elétrica nas diversas ações e fatores de ordem técnica, econômica e social.
} 
que se efetivem políticas e ações para esse objetivo, chega a um consumo de 56.303 GWh, distribuído da seguinte forma: residencial - 11.413 GWh, comercial - 13.142 GWh, industrial - 25.506 GWh e outros - $6.242 \mathrm{GWh}^{5}$.

Este potencial alivia a carga nas centrais geradoras de eletricidade em aproximadamente 7.200 $\mathrm{MW}_{\text {med }}$ anuais. Além desta questão, outras razões despertam os interesses do agente público com as atividades de conservação e eficiência energética. Elas variam desde preocupações com o impacto evitado ao meio ambiente até a garantia no suprimento de energia.

Tendo apresentado uma breve discussão sobre situação atual e as projeções do mercado de energia, outro importante aspecto para caracterizar a temática energética brasileira é a discussão sobre tipos de geração existentes, a participação de cada fonte no SIN indicando a participação de cada subsistema que país foi subdividido pelo Operador Nacional do Sistema (ONS).

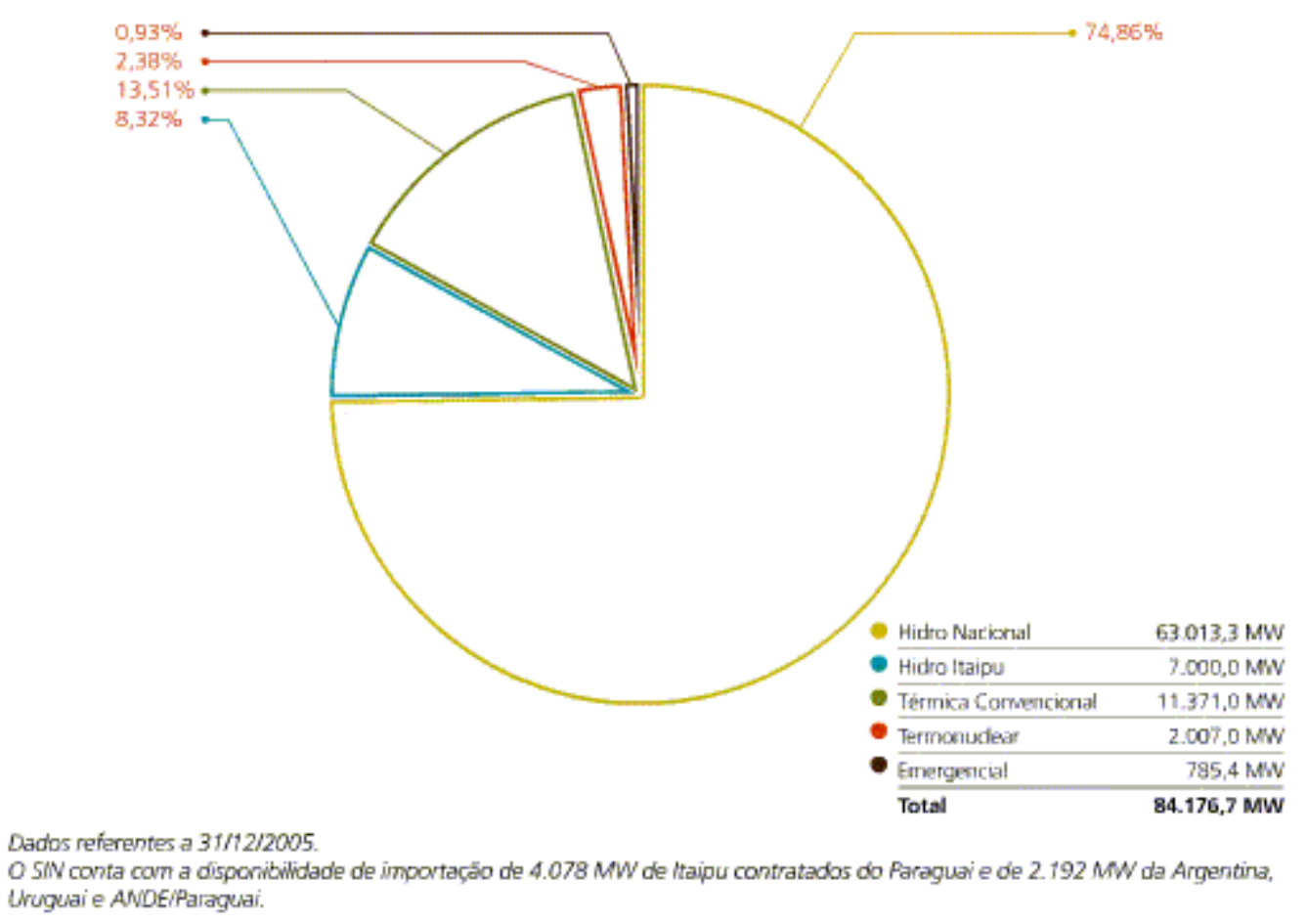

Figura 2.2. Estrutura da Capacidade Instalada no SIN - MW Fonte: ONS

A distribuição das opções de geração de eletricidade está disposta na Figura 2.2. Percebe-se a predominância da geração hidráulica seguida da fonte termoelétrica. As fontes consideradas

\footnotetext{
${ }^{5}$ No PDEE não foi detalhado os planos/programas tão pouco as premissas para se alcanças os números apresentados.
} 
emergenciais são também opções de termoeletricidade e operam sob um regime diferenciado de despacho centralizado no SIN.

A Figura 2.2. apresenta a distribuição do potencial em geração de eletricidade por fonte primária de energia no Sistema Interligado Nacional. A predominância da hidroeletricidade é característica da matriz energética brasileira o que lhe provê no cenário internacional uma característica de uma matriz considerada limpa pela baixa participação de combustíveis fósseis e derivados de petróleo comparativamente a outros países. Por outro lado, existem questionamentos relativos aos impactos socioambientais gerados pelos grandes empreendimentos hidrelétricos.

Tabela 2.1. Geração de eletricidade por fonte de energia GWh Fonte: ONS

\begin{tabular}{|c|c|c|c|c|c|c|}
\hline Origem & 2001 & 2002 & 2003 & 2004 & 2005 & $\begin{array}{c}\text { Variação \% } \\
2005 / 2001\end{array}$ \\
\hline Hidrelétrica & $219.651,6$ & $238.517,6$ & $253.815,0$ & $268.178,4$ & $288.569,0$ & 31,4 \\
\hline Itaipu & $72.733,9$ & $76.899,8$ & $83.007,2$ & $83.788,3$ & $81.736,4$ & 12,4 \\
\hline Óleo Diesel & 343,3 & 43,8 & 0,0 & 0,0 & 0,0 & $-100,0$ \\
\hline $\begin{array}{l}\text { Óleo } \\
\text { Combustível }\end{array}$ & $6.774,7$ & $3.371,6$ & 863,5 & 382,2 & 379,8 & $-94,4$ \\
\hline Gás Natural & $6.114,4$ & $8.929,2$ & $9.182,0$ & $14.449,9$ & $13.897,8$ & 127,3 \\
\hline Carvão & $6.241,1$ & $5.062,1$ & $5.239,3$ & $6.346,1$ & $6.107,3$ & $-2,1$ \\
\hline Nuclear & $14.278,7$ & $13.849,5$ & $13.357,9$ & $11.582,6$ & $9.855,5$ & $-31,0$ \\
\hline Emergencial & & 24,8 & 51,5 & 398,7 & 18,3 & \\
\hline $\begin{array}{l}\text { Compra } \\
\text { Adicional }\end{array}$ & & 5,2 & & & & \\
\hline Total & $326.137,7$ & $346.703,6$ & $365.516,4$ & $385.126,2$ & $400.564,1$ & 22,8 \\
\hline
\end{tabular}

No entanto, a diversificação da matriz energética brasileira, fruto de um posicionamento estrutural do governo motivado pela vontade de reduzir a dependência hidráulica tem incentivado a participação do gás natural na matriz energética do país. A participação deste combustível praticamente mais que dobrou em relação a 2001, como é evidenciado na Tabela 2.1. Outro fato que evidencia a inserção do gás natural na matriz energética é a existência de usinas termoelétricas com a opção de uso tanto de GN quanto de óleo combustível (OC) conhecidas como bicombustíveis.

Tal fato justifica também a queda na geração das usinas à OC visto que muitas optaram pela conversão ou pela flexibilidade do uso de ambos os combustíveis dependendo do comportamento do mercado para estes produtos já que o custo da energia para estes é 
fortemente dependente do preço do insumo energético primário (combustível). Além da sujeição destas usinas à variação do preço do OC no mercado, estão também atreladas às condições operativas mais restritivas por motivos ambientais.

Apesar do potencial carbonífero existente na região sul do país, o aproveitamento do mesmo para geração de eletricidade permanece em patamares estáveis, tendo em vista a série de impactos tanto de ordem social, quanto ambientais decorrentes do aproveitamento deste tipo de combustível. Não obstante, a opção do combustível nuclear é um assunto amplamente debatido no país e controverso, tendo como únicas opções em operação até o presente momento para este tipo de tecnologia as Usinas Termonucleares de Angra I e II situadas no Estado do Rio de Janeiro.

\subsection{GERAÇÃO DE ENERGIA COM BIOMASSA}

Embora a biomassa tenha sido o primeiro vetor energético empregado pela humanidade e ainda seja uma fonte energética de importância, a produção de eletricidade a partir da biomassa é restrita (Walter e Nogueira, 1997). Em geral, o processo de aproveitamento energético da biomassa segue as seguintes rotas tecnológicas sob a perspectiva da energia elétrica como produto final:

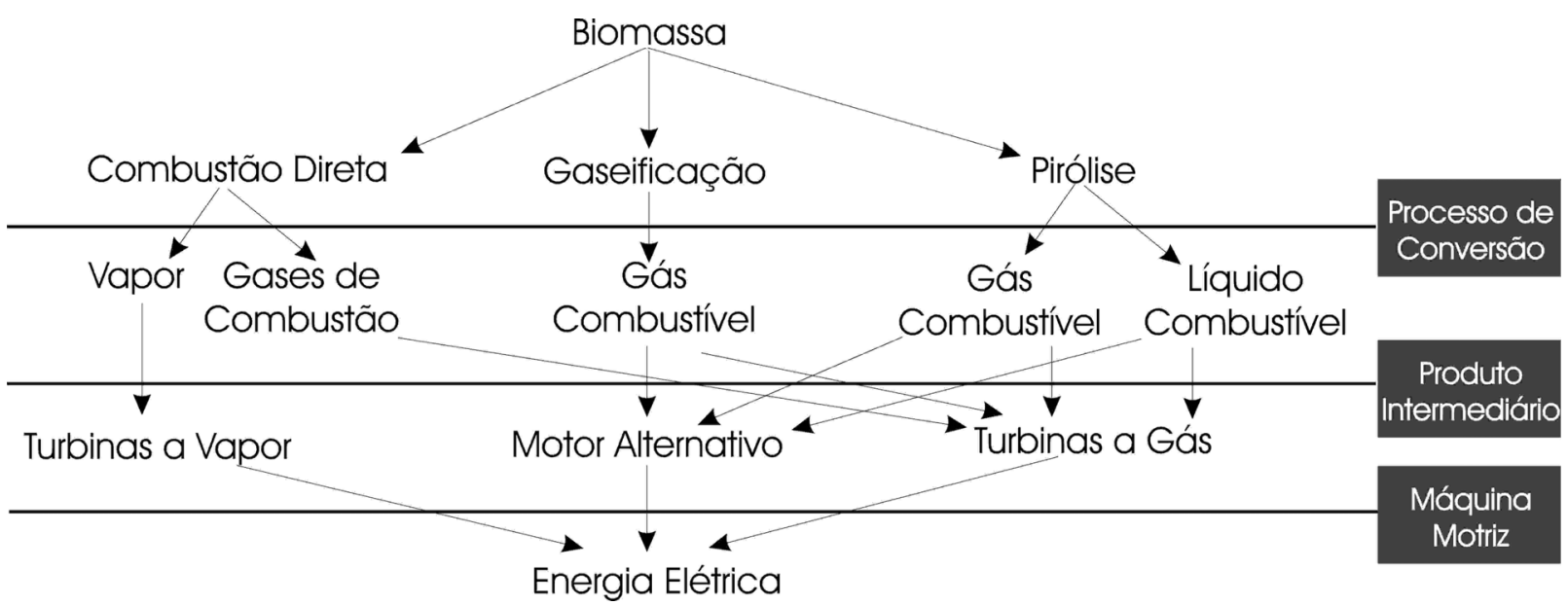

Figura 2.3. Alternativas tecnológicas para geração de eletricidade a partir de biomassa. (Walter e Nogueira, 1997) 
A utilização da biomassa produzida no ciclo produtivo da indústria sucroalcooleira se destaca no uso do bagaço de cana-de-açúcar, a palha e pontas da planta como combustíveis ainda com a possibilidade da utilização da vinhaça pelo processo de biodigestão. Estes aproveitamentos estão num contexto de opção complementar à expansão do sistema elétrico brasileiro que se encontra numa fase de consolidação das regras do novo modelo institucional apresentado em 2003/2004.

O aproveitamento energético da biomassa da cana-de-açúcar pode ser repartido em energias nas formas térmica (vapor d'água), mecânica (acionamento mecânicos), elétrica (motores, máquinas, sistemas de controle, equipamentos em geral etc ...). O setor sucroalcooleiro, hoje, apresenta vantagens potenciais que devem ser seriamente consideradas no que se refere à geração excedente de eletricidade:

- atualmente, a eficiência global é baixa no aproveitamento do bagaço de cana, pois na maioria das unidades de produção de açúcar e álcool os equipamentos de combustão, as turbinas, os acionamentos mecânicos e o isolamento térmico são de baixa eficiência apresentando pouca sofisticação. Apresentando uma possibilidade de redução significativa do consumo de vapor e calor, condições estas que indicam a possibilidade de aumento considerável da quantidade de bagaço de cana que pode ser disponibilizado para a geração de excedentes de energia elétrica;

- a geração de eletricidade a partir do bagaço disponível é, hoje em dia, em torno de 10 vezes menor do que poderia ser mediante a utilização de gaseificação de biomassa ou ciclos combinados de geração elétrica (Neto, 2001);

- a modificação do processo de colheita, tradicionalmente feito através da queima prévia do canavial, para um processo mecanizado de colheita da cana crua devido principalmente às pressões ambientais para redução da poluição atmosférica nas regiões canavieiras, colocará a disposição uma nova quantidade de biomassa, proveniente das pontas e palha da cana na mesma ordem que a quantidade de bagaço hoje disponível. Mesmo considerando a possibilidade de que apenas $50 \%$ (Neto, 2001) desta matéria vegetal possa ser retirada do campo, devido a sua importância para fertilização do solo, manutenção das condições bióticas do mesmo e redução do uso de fertilizantes artificiais;

- sob o aspecto ambiental, além da emissão de carbono quase nula na atmosfera, sob ponto de vista do ciclo completo, o uso do bagaço, palha e pontas da cana-de-açúcar para geração de 
energia elétrica, através da cogeração, tem a vantagem de aumentar a eficiência global da planta com tecnologias já dominadas pela indústria nacional não trazendo maiores impactos do que aqueles com o qual o setor já vem lidando. Na mecanização da colheita, os aspectos negativos são a compactação do solo e a eliminação dos postos de trabalho, sendo este último marcado pela controvérsia, uma vez que a qualidade da grande maioria dos empregos gerados é baixa; porém muito compatível com o grau de qualificação da mão de obra disponível em várias regiões rurais do país; e,

- a complementaridade entre o período de safra, onde o excedente de eletricidade é gerado, com o período de baixos índices pluviométricos que afetam diretamente a maneira como as usinas hidroelétricas são operadas torna o aproveitamento da energia elétrica desse setor uma ferramenta estratégica para o planejamento do setor elétrico.

As principais limitações ao emprego de biomassa na produção de eletricidade são:

- os custos de produção e do transporte da biomassa são determinantes para a viabilidade econômica dos projetos que prevêem seu uso para fins energéticos;

- a reduzida eficiência de conversão energética da biomassa em eletricidade e a baixa capacidade unitária dos sistemas considerando as tecnologias convencionais que estão praticamente limitadas às instalações de geração a vapor, sem incentivos efetivos de investidores privados, linhas de financiamento apropriadas e políticas capazes de incentivar a melhora desse cenário, são algumas das justificativas do baixo interesse em se alterar a situação;

- há necessidade de que os benefícios ambientais sejam assegurados em toda cadeia de produção de biomassa e eletricidade, dado que a questão ecológica é uma de suas principais justificativas. A produção de culturas energéticas em larga escala pode ter importantes efeitos colaterais, tais como problemas associados à monocultura, perda da biodiversidade, degradação do solo e o possível excesso no uso de defensivos agrícolas; e,

- complexidade, em termos da multidisciplinaridade na integração dos sistemas que usam biomassa. Essa complexidade deriva da combinação de fatores que não são só técnicos e econômicos, mas abrangem as questões ambientais, políticas, sociais, estratégicas e etc. 


\subsection{REPRESENTATIVIDADE DO SETOR NA MATRIZ ENERGÉTICA ${ }^{6}$}

Dando continuidade a contextualização proposta, os dados apresentados a seguir foram extraídos das seguintes fontes:

- Balanço Energético:

○ Nacional (BEN); e,

○ Estado de São Paulo (BESP).

\subsubsection{NO BRASIL}

A Tabela 2.2. apresenta a geração de eletricidade por unidade da federação para o ano base 2004, o qual o Balanço Energético Nacional de 2005 se refere ${ }^{7}$. Destaca-se a participação na geração de eletricidade nos Estados do Paraná, São Paulo e Minas Gerais.

\footnotetext{
${ }^{6}$ Leia-se Matriz de Eletricidade. Para uma análise mais ampla da questão energética sobre a indústria sucroalcooleira, a questão da produção do etanol, seu aproveitamento e desdobramentos devem ser considerados. No entanto, o foco deste trabalho é a geração de eletricidade.

${ }^{7}$ O Balanço Energético Nacional de 2006, ainda não foi publicado. Estando seus resultados parciais disponíveis no site do Ministério de Minas e Energia (MME) - http://www.mme.gov.br
} 
Tabela 2.2. Geração de Energia Elétrica por Estado GWh Fonte: BEN 2005

\begin{tabular}{lrc}
\hline \multicolumn{1}{c}{ ESTADO } & $\begin{array}{r}\mathbf{2 0 0 4} \\
\mathbf{G W h}\end{array}$ & $\begin{array}{c}\text { Participação \% na } \\
\text { Geração em 2004 }\end{array}$ \\
\hline ACRE & 331 & 0,1 \\
RONDÔNIA & 2506 & 0,6 \\
AMAZONAS & 5667 & 1,5 \\
RORAIMA & 3 & 0,0 \\
PARÁ & 31385 & 8,1 \\
AMAPÁ & 850 & 0,2 \\
TOCANTINS & 4633 & 1,2 \\
MARANHÃO & 749 & 0,2 \\
PIAUÍ & 680 & 0,2 \\
CEARÁ & 1705 & 0,4 \\
RIO G. DO NORTE & 140 & 0,0 \\
PARAÍBA & 79 & 0,0 \\
PERNAMBUCO & 4871 & 1,3 \\
ALAGOAS & 16388 & 4,2 \\
SERGIPE & 8438 & 2,2 \\
BAHIA & 18888 & 4,9 \\
MINAS GERAIS & 47659 & 12,3 \\
ESPÍRITO SANTO & 4620 & 1,2 \\
RIO DE JANEIRO & 26134 & 6,7 \\
SÃO PAULO & 56756 & 14,6 \\
PARANÁ & 84506 & 21,8 \\
SANTA CATARINA & 11185 & 2,9 \\
RIO G. DO SUL & 15568 & 4,0 \\
MATO G. DO SUL & 15222 & 3,9 \\
MATO GROSSO & 5474 & 1,4 \\
GOIÁS & 22914 & 5,9 \\
DISTRITO FEDERAL & 112,64 & 0,0 \\
\hline
\end{tabular}

Os dados da Tabela 2.2. podem ser agrupados por região e, conseqüentemente, possibilita visualizar os subsistemas que compõem o sistema elétrico brasileiro. Esta distribuição é apresentada na Figura 2.4.
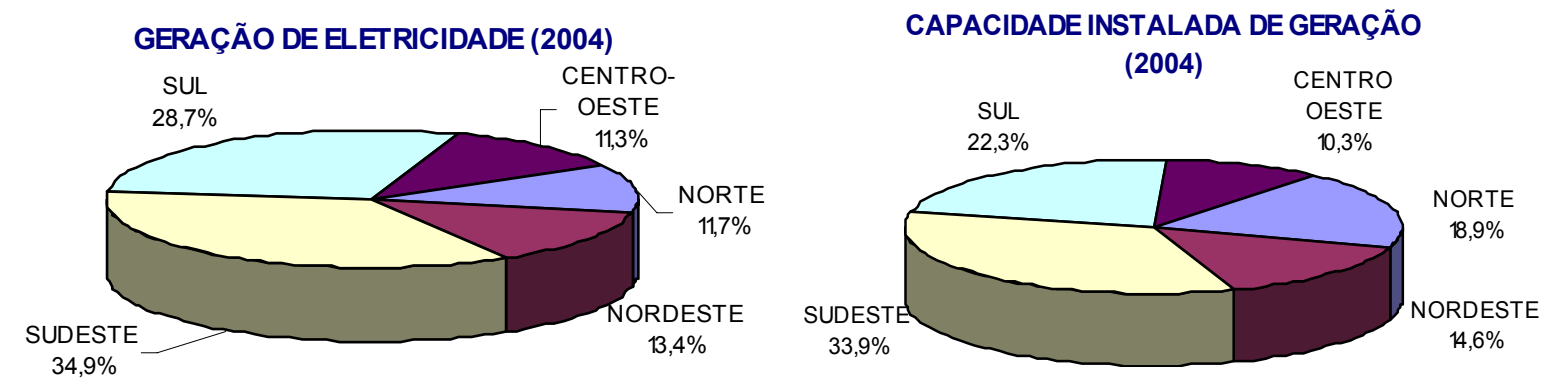

Figura 2.4. Participação por região na geração de eletricidade e capacidade instalada Fonte: BEN 2005 
Da Figura 2.4., depreende-se que mais da metade da geração de eletricidade e da capacidade instalada do parque gerador estão localizados nas regiões Sudeste e Sul do país. Com relação ao potencial de aproveitamento hidrelétrico, estas mesmas regiões se encontram com, aproximadamente, 53,2 \% e 45,5\% do potencial hidrelétrico explorado segundo o Balanço Energético Nacional de 2005.

Tabela 2.3. Participação de cada Unidade da Federação no Total de Autoprodução ${ }^{8}$ de Eletricidade no Brasil GWh Fonte: BEN 2005

\begin{tabular}{ccc}
\hline UF & Energia GWh & Participação no País \% \\
& & \\
\hline RO & 53 & 0,1 \\
AC & 0 & 0,0 \\
AM & 284 & 0,7 \\
RR & 3 & 0,0 \\
PA & 728 & 1,9 \\
AP & 0 & 0,0 \\
TO & 0 & 0,0 \\
\hline MA & 95 & 0,3 \\
PI & 3 & 0,0 \\
CE & 93 & 0,2 \\
RN & 117 & 0,3 \\
PB & 73 & 0,2 \\
PE & 319 & 0,8 \\
AL & 491 & 1,3 \\
SE & 72 & 0,2 \\
BA & 2168 & 5,7 \\
\hline MG & 7146 & 18,8 \\
ES & 3285 & 8,7 \\
RJ & 6444 & 17,0 \\
SP & 11572 & 30,5 \\
\hline PR & 1909 & 5,0 \\
SC & 621 & 1,6 \\
RS & 1083 & 2,9 \\
\hline MS & 166 & 0,4 \\
MT & 965 & 2,5 \\
GO & 219 & 0,6 \\
DF & 3 & 0,0 \\
\hline
\end{tabular}

Primeiramente, conceitua-se um Autoprodutor de energia elétrica, aquela pessoa física ou jurídica ou empresas reunidas em consórcio que recebam concessão ou autorização para

\footnotetext{
${ }^{8}$ Autoprodutor é definido pelo DECRETO No 2.003, DE 10.09.1996 - DOU 11.09.1996 - Art. $2^{\circ}$
} 
produzir energia elétrica destinada ao seu uso exclusivo. Outra definição importante é o de Produtor Independente de Energia ${ }^{9}$ (PIE) que pode produzir eletricidade com o fim de comercializar toda ou parte da energia produzida, por sua conta e risco ${ }^{10}$.

Novamente, destaca-se a região sudeste na participação da autoprodução de eletricidade em relação às demais regiões no país. O Estado de São Paulo apresenta a maior participação no segmento de autoprodução de energia elétrica superando em até 38\% a autoprodução dos estados de Minas Gerais e Rio de Janeiro.

Realizando uma análise mais detalhada da autoprodução por fontes de geração, ela representa cerca de 11,8\% do consumo de eletricidade país. Quando analisada por setores da economia, tem-se a seguinte configuração:

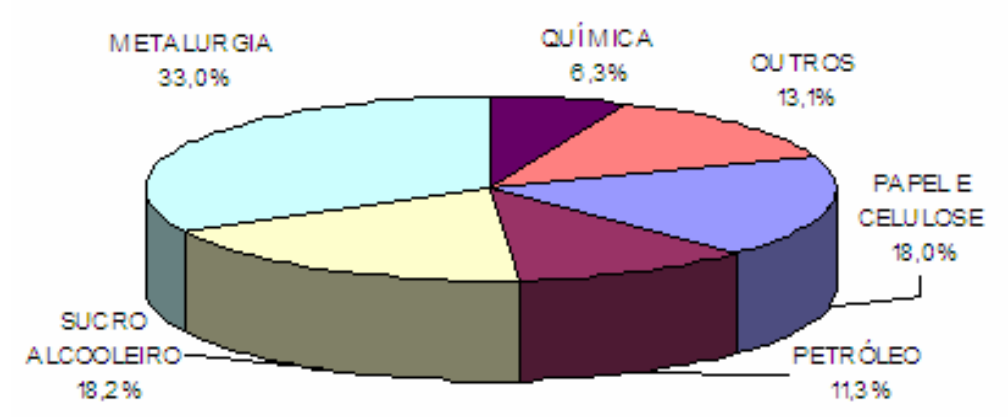

\section{Figura 2.5. Distribuição da autogeração de eletricidade no Brasil por setores da economia Fonte: BEN 2005}

A biomassa responde por cerca de $32,9 \%$ do total de energia gerada por autoprodução no Brasil. Analisando esta fonte, 18,4 \% são provenientes do bagaço da cana-de-açúcar sendo esta a maior participação por fonte para geração de energia dentre as fontes apresentadas na árvore de análise da biomassa apresentadas no BEN 2005. Destes resultados, destaca-se que o setor sucroalcooleiro consome a própria energia gerada para alimentar os seus processos industriais, sendo excedente de eletricidade passível de exportação aos sistemas de transmissão ou subtransmissão.

Por fim, dentro dos conceitos apresentados acima, a indústria do açúcar e álcool pode ser enquadrada como autoprodutora de energia elétrica nos casos onde não há conexão para

\footnotetext{
${ }^{9}$ Produtor Independente de Energia: definido pelo DECRETO N ${ }^{\mathrm{o}} 2.003,10.09 .1996$ - DOU 11.09.1996Art. $1^{\mathrm{o}}$

${ }^{10}$ Um aprofundamento sobre os conceitos de Autoprodutor e PIE são encontrados em (Brighenti, 2003) no Capítulo 1.
} 
comercialização de excedentes de eletricidade ou como Produtora de Independente de Energia, quando a Usina comercializa este excedente com o SIN e redes de média tensão. $\mathrm{O}$ potencial do setor como PIE será discutido nas próximas seções, mais especificamente no Estado de São Paulo, objeto deste estudo.

\subsubsection{NO ESTADO DE SÃO PAULO}

Esta seção está calcada no estudo de Matriz Energética de 2006 a 2016 realizado pela Secretaria de Energia, Recursos Hídricos e Saneamento do Estado de São Paulo, onde se analisou o comportamento passado da demanda por energéticos, discretizada por classe de consumo (industrial, transporte, residencial, comércio e serviços e demais classes), procurando determinar seu comportamento futuro. Novamente, como foi realizado para o Balando Energético Nacional, três cenários foram utilizados para construção tendêncial das elasticidades entre o Produto Interno Bruto Setorial e do Estado de São Paulo com o consumo de energia por classe e tipo de combustível no Estado. A base de dados utilizada para a realização dessa Matriz Energética foi a do Balanço Energético do Estado de São Paulo 2005 que contém uma série histórica de 1980 até o ano de 2004.

Tabela 2.4. Evolução da produção da Energia Primária Fonte: BESP 2006

\begin{tabular}{|c|c|c|c|c|c|c|c|}
\hline Energéticos $10^{3}$ tep & 1980 & 1985 & 1990 & 1995 & 2004 & Brasil & SP/BR \% \\
\hline Energia Hidráulica & 4.185 & 4.811 & 4.230 & 5.100 & 5.917 & 27.589 & 21,4 \\
\hline Produtos da Cana-de-Açúcar & 5.546 & 10.479 & 11.439 & 11.738 & 18.237 & 29.367 & 62,1 \\
\hline Lenha & 1.139 & 1.698 & 1.371 & 1.013 & 1.171 & 28.178 & 4,2 \\
\hline Gás Natural & 0 & 0 & 0 & 519 & 380 & 16.852 & 2,3 \\
\hline Outros & 309 & 476 & 594 & 1.069 & 1.657 & 11.582 & 14,3 \\
\hline
\end{tabular}

No ano de 2004, o BESP ressalta que o Estado de São Paulo foi responsável por 14,4\% de toda a energia primária produzida no Brasil. Dentre os energéticos, destacam-se a energia hidráulica e os produtos da cana, cujas participações do Estado na produção total do país por energético foram de $21,4 \%$ e $62,1 \%$, respectivamente. Um importante aspecto 
apresentado é que a extração/exploração de petróleo ${ }^{11}$ em território paulista é muito baixa, razão que deixa o Estado na dependência da importação deste importante energético.

O Estado de São Paulo possui um percentual significativo do PIB brasileiro, bem como apresenta uma alta concentração da indústria em diversos setores da economia nacional, além de possuir fundações, centros de pesquisas e universidades de relevância no Brasil. No entanto, mantém um grau de dependência energética, a ser demonstrado a seguir.

Segundo o BESP de 2006, em 2004 o Estado de São Paulo produziu o equivalente a 297.703 x $10^{9} \mathrm{kcal}$ de energia para um consumo final energético de $582.442 \times 10^{9} \mathrm{kcal}$, ou seja, uma dependência energética de 48,9\%. A tabela a seguir apresenta um histórico:

Tabela 2.5. Relação entre produção e consumo de energia final $10^{9}$ kcal Fonte: BESP 2006

\begin{tabular}{lccccccc}
\hline \multicolumn{1}{c}{ Ano } & $\mathbf{1 9 9 0}$ & $\mathbf{1 9 9 5}$ & $\mathbf{2 0 0 0}$ & $\mathbf{2 0 0 1}$ & $\mathbf{2 0 0 2}$ & $\mathbf{2 0 0 3}$ & $\mathbf{2 0 0 4}$ \\
\hline Produção & 181.911 & 216.833 & 220.214 & 237.742 & 257.992 & 277.226 & 297.703 \\
Consumo & 360.851 & 441.721 & 511.721 & 525.176 & 529.175 & 544.244 & 582.442 \\
Auto-suficiência & $50,40 \%$ & $49,10 \%$ & $43,00 \%$ & $45,30 \%$ & $48,80 \%$ & $50,90 \%$ & $51,10 \%$ \\
Dependência & $49,60 \%$ & $50,90 \%$ & $57,00 \%$ & $54,70 \%$ & $51,30 \%$ & $49,10 \%$ & $48,90 \%$ \\
\hline
\end{tabular}

Salvo o ano de 2000 onde houve uma redução na produção de cana de açúcar por problemas de safra, o que evidencia relação de dependência energética do Estado com os produtos da cana-de-açúcar, percebe-se que a dependência energética do Estado tem se mantido no patamar do início da década de 90 . A respeito da relativa estabilidade no grau de dependência energética do Estado de São Paulo, que é evidenciado pelos percentis da Tabela 2.5., o BESP prevê que este comportamento poderá se alterar significativamente nos próximos anos, dependendo do comportamento da economia paulista, principalmente, com as variações dos cenários alto, médio e baixo.

É importante salientar que o grau de dependência energética atual não se elevou em função do ritmo de crescimento da economia paulista. A estabilização do crescimento da produção de energia primária pelo Estado reflete também a redução dos potenciais energéticos de algumas fontes tradicionais como, por exemplo, a energia hidráulica.

\footnotetext{
${ }^{11}$ Salvo a condição de Gás Natural no Estado de São Paulo onde a Bacia de Santos apresenta um dos maiores potenciais de exploração de GN não associado (sem óleo bruto, apenas gás e C5+ (condensado que tratado se torna gasolina e GLP)).
} 
O Estado de São Paulo tem hoje o seu potencial de energia hidráulica quase em sua totalidade explorado, excetuando-se pequenos aproveitamentos hidrelétricos. A produção de energia hidráulica, segundo o Balanço Energético no Estado, detinha uma participação de 25,0 \% do total da energia primária produzida internamente, em 1990; e, passou a representar o equivalente a 19,5\% em 2004 (BESP, 2006).

Com relação à produção de gás natural no Estado proveniente da bacia de Santos, ressalta-se que em função dos dados disponíveis pode-se constatar que houve um crescimento expressivo entre os anos de 2000 a 2004 de 224,0 \% (BESP, 2006).

Destaque para a cana-de-açúcar que elevou a sua participação de 65,9 \% em 1990 para 69,7 \% em 2004, com um crescimento médio nos últimos 5 anos de $11,75 \%$ da produção de energia primária (BESP, 2006).

Considerando o setor industrial, o bagaço da cana-de-açúcar é o energético predominante na matriz deste setor seguida da eletricidade e gás natural, respectivamente. Tal fato, novamente, dá destaque a este insumo.

Outro aspecto que merece atenção na avaliação da matriz energética do Estado de São Paulo é o comportamento do óleo combustível e o bagaço no período de 1990 a 2004. O óleo combustível teve sua participação sistematicamente reduzida ao longo do tempo e apenas voltou a crescer em 2001, período da crise energética no país. Em sentido contrário, o bagaço de cana tem sua participação aumentada, na média, no transcorrer das décadas, o que segundo o BESP, sugere uma substituição ao óleo combustível.

Outros energéticos passam a ganhar relevância na matriz do Estado; o gás natural que apresentava uma pequena participação em 1980, diferentemente do óleo combustível e do bagaço de cana, cresceu de forma constante ao longo dos anos. O BESP (2006) procura demonstrar a importância que este energético adquiriu na matriz, não só em termos de participação, mas, sobretudo em velocidade, afirmando que o crescimento médio anual foi o mais alto entre todos os energéticos, 13,0 \% a.a. 


\subsubsection{CONTEXTUALIZAÇÃO DESSE APROVEITAMENTO NO PLANEJAMENTO ENERGÉTICO}

Dos levantamentos apresentados tanto no Balanço Energético Nacional quanto do Estado de São Paulo, percebe-se que a participação do setor sucroalcooleiro, quantitativamente, é relevante dentro do contexto energético.

Esta importância ganha destaque seja no deslocamento da utilização de combustíveis fósseis como o óleo combustível ou na complementaridade com a geração hidrelétrica no Estado de São Paulo.

Já no cenário Nacional, este setor ganha destaque quando trabalhada sob a ótica do autoprodutor de eletricidade. Neste caso, para a indústria do açúcar e álcool, eletricidade e energia térmica provenientes da cogeração.

Faccenda e Souza (1995) apresentaram com base nos valores do consumo horário de eletricidade, a relação entre a capacidade instalada com a demanda de energia elétrica, servindo para avaliar o potencial que a cogeração possui. O mesmo destaca:

a) o fato da colheita da cana-de-açúcar ocorrer no período de menor disponibilidade hídrica, quando um melhor emprego do bagaço proveniente do processamento da cana no Estado de São Paulo poderia gerar um excedente de energia elétrica para ser vendido às concessionárias;

b) a lacuna existente no fomento efetivo à cogeração. A conseqüência imediata desta indefinição é que as indústrias sucroalcooleiras no país ficaram limitadas a serem autosuficientes em energia elétrica ou no máximo a produzirem pequenos excedentes para serem vendidos às concessionárias. Isto é, existe margem para melhora na eficiência energética e conservação de energia das plantas industriais deste setor, aumentando a quantidade de eletricidade exportada e contribuindo com o desenvolvimento sustentável;

c) no período de safra da cana-de-açúcar (maio a novembro), o consumo de energia elétrica é maior e, de forma inversa, nos meses de entressafra (dezembro a abril) o consumo de energia elétrica é menor; e, 
d) a cogeração poderia ser operada de forma a acrescentar energia firme ${ }^{12}$ ao parque gerador, entre $6,17 \%$ e $11,5 \%{ }^{13}$, com o objetivo de equacionar a sazonalidade anual do consumo e geração de energia elétrica da rede no Estado.

Do exposto, a cogeração com base na sazonalidade existente pode contribuir para a manutenção dos níveis dos reservatórios das barragens, reduzindo os riscos na operação do sistema elétrico e no fornecimento de eletricidade principalmente nas situações onde o regime hídrico encontra-se debilitado.

No entanto, o Plano Decenal de Expansão de Energia Elétrica 2006-1015 (PDEE) pouco trata das estratégias voltadas ao segmento de autoprodução. Na verdade, a cogeração surge no PDEE com base no gás natural, considerando aproveitamento do bagaço na cogeração como uma atividade absorvida pelo PROINFA. Mais à frente será visto o impacto desta consideração no Planejamento do Setor Elétrico.

\subsection{DADOS DA PRODUÇÃO}

Esta seção visa apresentar a produção de açúcar e álcool no Brasil e no Estado de São Paulo de forma a retratar a posição atual do setor, bem como indicar a tendência da produção.

O emprego e a avaliação destas informações afetam diretamente a questão energética considerando que, hoje, a geração de eletricidade não é o principal objetivo e produto da indústria sucroalcooleira.

Além disso, a análise destas informações permite posicionar o Estado de São Paulo neste setor econômico, considerando a sua relevância em comparação às demais regiões produtoras do setor.

\footnotetext{
${ }^{12}$ Energia Firme, é a energia produzida continuamente, durante o período crítico do sistema ou da usina.

${ }^{13}$ Para projeções de consumo/demanda até o ano de 2002.
} 


\subsubsection{CENÁRIO NACIONAL E DO ESTADO DE SÃO PAULO}

As Figuras 2.6. a 2.8. apresentam a produção de cana-de-açúcar, açúcar e álcool respectivamente em números consolidados para o País, agregados regionalmente em CentroSul e Norte-Nordeste e para o Estado de São Paulo.

Com relação à produção de cana no Brasil, a produção nacional manteve-se aproximadamente constante numa análise quantitativa nas duas últimas safras devido à queda na produção canavieira ocorrida na região norte-nordeste, em específico nos Estados de Pernambuco e Alagoas. Mesmo assim, nas demais regiões a tendência de aumento das safras permaneceu, principalmente no Estado de São Paulo, Estado que predomina no volume de cana produzida no país e, consequentemente, nos valores encontrados para a região centro-sul.

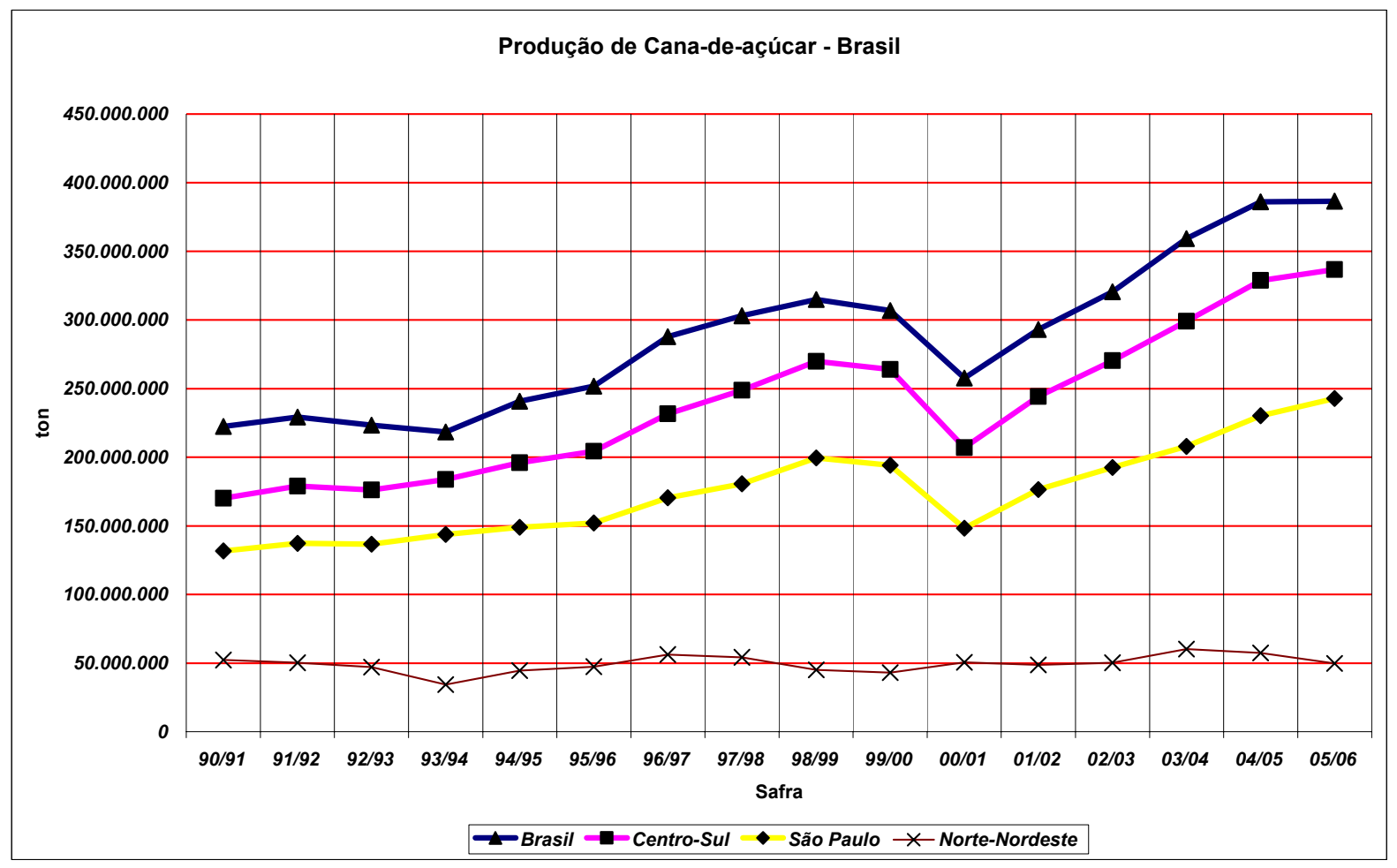

Figura 2.6. Produção de cana-de-açúcar no Brasil, regiões centro-sul, norte-nordeste e Estado de São Paulo Fonte: UNICA 


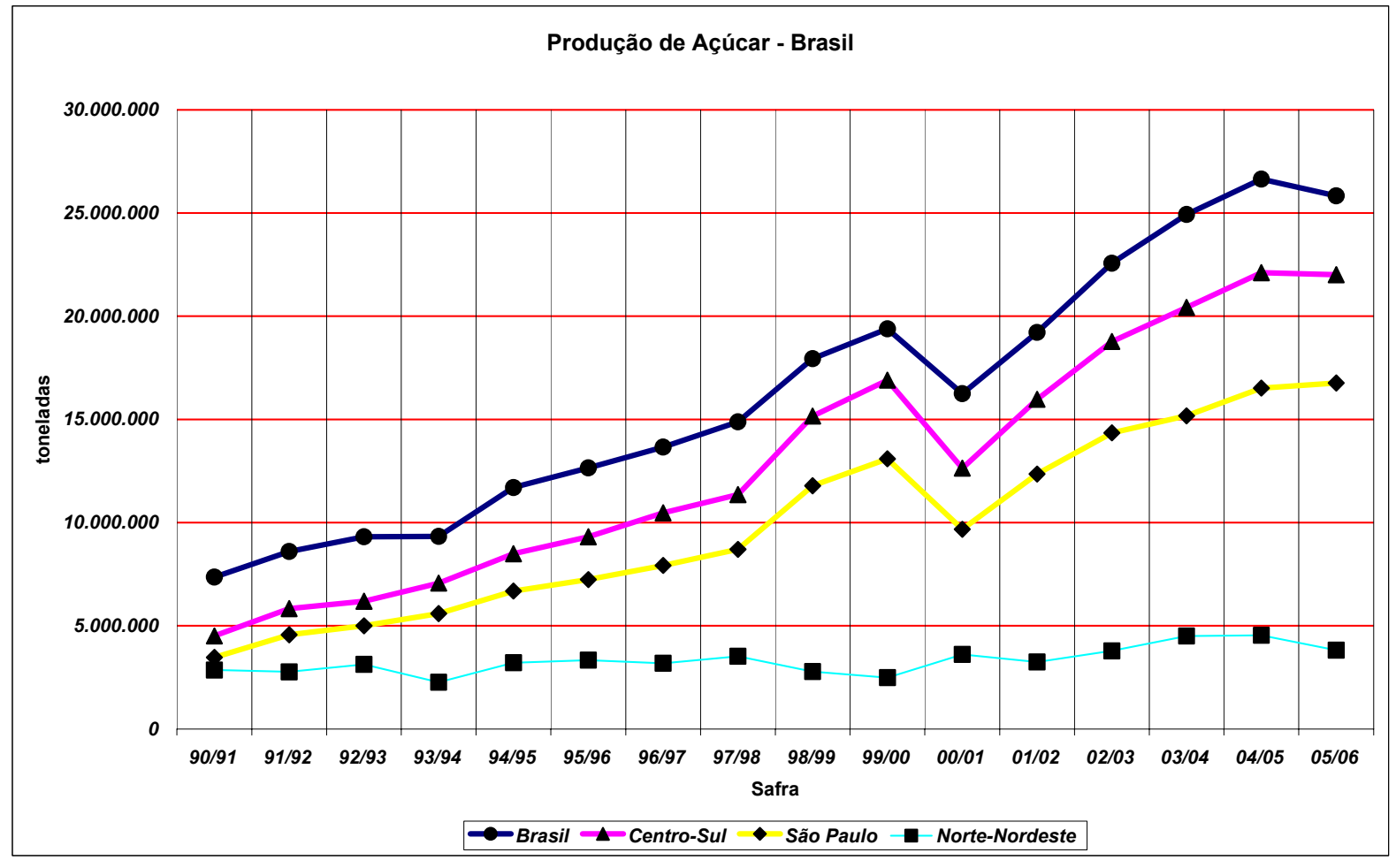

Figura 2.7. Produção de açúcar no Brasil, regiões centro-sul, norte-nordeste e Estado de São Paulo Fonte: UNICA

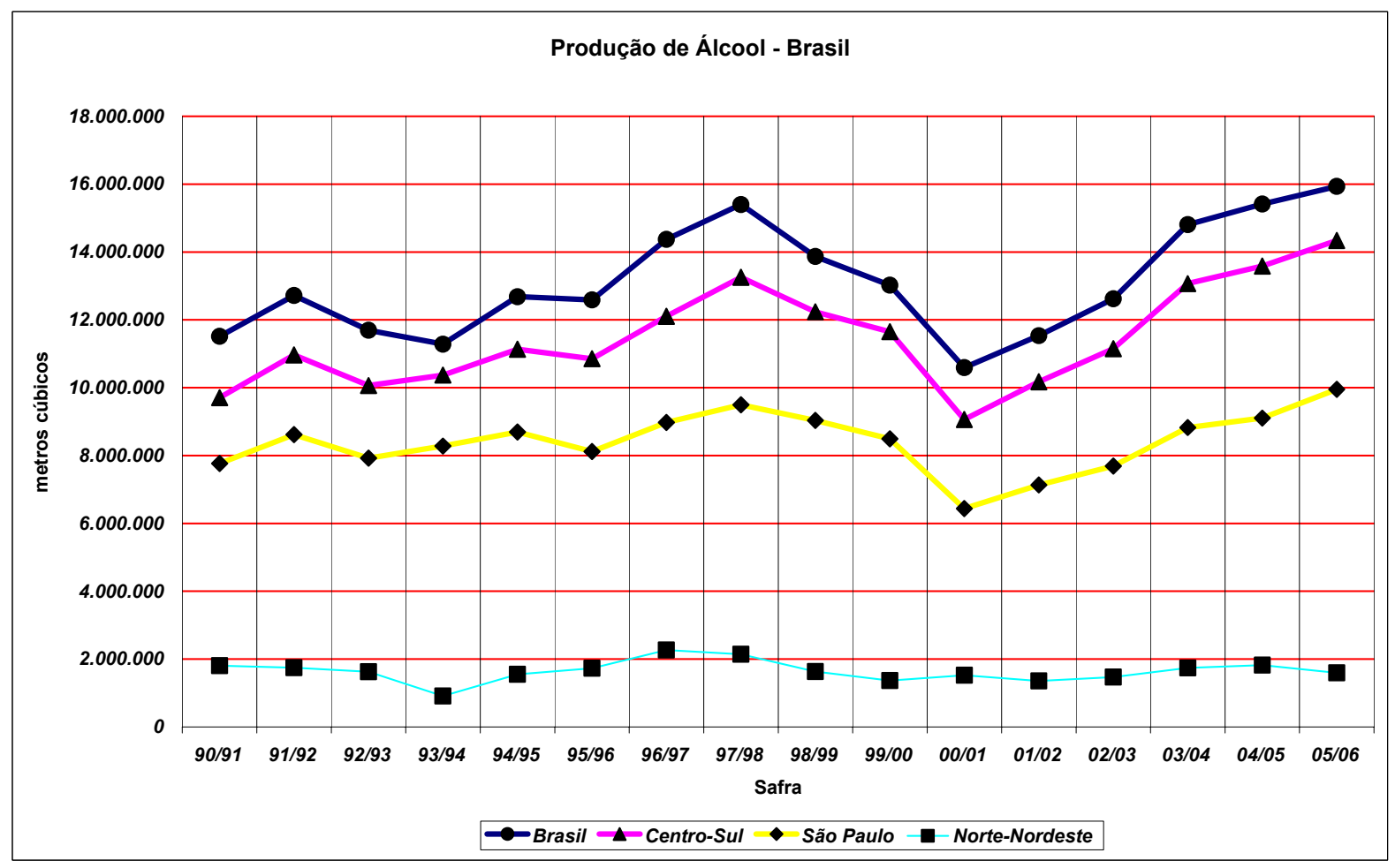

Figura 2.8. Produção de álcool no Brasil, regiões centro-sul, norte-nordeste e Estado de São Paulo Fonte: UNICA 
É interessante apontar, nas três figuras apresentadas nesta seção, o comportamento relatado no BESP 2006 na Safra 00/01, onde o problema de safra implicou no aumento da dependência energética no Estado de São Paulo para aquele ano. E como era de se esperar, como este Estado possui um grande peso em relação à produção do setor, o mesmo comportamento foi refletido nas curvas de produção do país e da região centro-sul.

Ao contrário, da tendência de aumento da região centro-sul, na região norte-nordeste a produção ao longo do período apresentado (1994-2006) manteve-se praticamente nos mesmos patamares. Tal fato ocorre, pois a produção no nordeste responde praticamente pela produção agregada da região norte-nordeste, recebendo subsídios do governo brasileiro para equalizar os preços na produção de cana-de-açúcar com as demais regiões e tornar a atividade nesta região competitiva em relação ao sudeste do país (Andrade, 2001).

\subsection{INSTRUMENTOS DE INCENTIVO À GERAÇÃO DE ELETRICIDADE A PARTIR DA BIOMASSA DA CANA-DE-AÇÚCAR}

Estudos feitos pelo CENBIO mostram que existe uma grande capacidade de geração de excedente de energia no setor sucroalcooleiro, com um potencial técnico de excedentes de quase 4.000 MW, em termos de energia firme, nos estados da região Nordeste, Centro-Oeste e Sudeste (CENBIO, 2001). Entretanto, os projetos existentes no setor sucroalcooleiro destes estados, para curto, médio e longo prazo totalizavam um excedente de apenas $1.600 \mathrm{MW}$, segundo Brighnenti (2003).

Para melhor explorar esta oportunidade que existe no ciclo produtivo da cana-de-açúcar no que concerne à comercialização do excedente de energia elétrica, deve-se procurar superar algumas barreiras existentes. Elas incluem dificuldade como acesso à rede, falta da atratividade no preço ofertado para comercialização, falta de interesse das concessionárias para contratos de longo prazo, financiamentos com condições atrativas aos empreendedores, entre outros a serem detalhados adiante.

Atualmente podem-se vislumbrar as seguintes iniciativas visando incentivar a geração de energia elétrica a partir de fontes renováveis: 
- Programa de Incentivo às Fontes Alternativas de Energia

- Mecanismo de Desenvolvimento Limpo

Estas iniciativas serão trabalhadas a seguir, buscando sempre a sua aplicação na geração de energia a partir dos produtos da cana-de-açúcar com ênfase no Estado de São Paulo.

\subsubsection{INCENTIVO NO ARCABOUÇO REGULATÓRIO DO SETOR ELÉTRICO}

Em julho de 2003, o Ministério de Minas e Energia publicou o documento que aprova as diretrizes básicas para a implementação do novo modelo do Setor Elétrico.

Este novo modelo encontra-se justificado pela não obtenção de resultados favoráveis no modelo vigente ao que se refere à modicidade tarifária, continuidade e qualidade da prestação de serviços, ausência de incentivos à expansão, a universalização do acesso e o uso aos serviços de energia elétrica. Além da Crise de Abastecimento ocorrida no período de 2001/2002 que implicou na redução induzida do consumo de energia elétrica no período do racionamento e, como foi visto anteriormente, mantiveram-se num período pós-racionamento fatores estes que, somados à entrada de nova geração e regime hidrológicos favoráveis, implicaram posteriormente em sobre oferta de energia.

Ademais, a crise no abastecimento demonstra a fragilidade do modelo em corrigir os desequilíbrios entre oferta e demanda sem apresentar de forma adequada os sinais de preços e investimentos.

Na nova proposta institucional, as seguintes diretrizes são apresentadas:

a) Conceito de Serviço Público para a produção e distribuição de energia elétrica aos consumidores cativos;

b) Modicidade Tarifária;

c) Restauração do Planejamento da Expansão do Sistema;

d) Transparência no processo de licitação permitindo a contestação pública, por técnica e preço, das obras a serem licitadas; 
e) Mitigação dos Riscos Sistêmicos;

f) Manter a operação coordenada e centralizada necessária e inerente ao sistema hidrotérmico brasileiro;

g) Universalização do acesso e do uso dos serviços de eletricidade; e,

h) Modificação no processo do modelo de licitação da concessão do serviço público de geração priorizando a menor tarifa.

Os agentes de distribuição deverão, obrigatoriamente, contratar para o atendimento à totalidade do mercado, a energia elétrica advinda:

a) de contratos já existentes;

b) contratos via leilão de energia elétrica; e,

c) provenientes de:

i. geração distribuída; e,

ii. energia elétrica gerada pelo PROINFA.

A geração distribuída, de despacho descentralizado e de pequeno porte ${ }^{14}$, pode ser adquirida diretamente pelos distribuidores desde que a unidade geradora esteja integrada a sua rede, podendo esta ser própria (distribuidores com mercado próprio até $300 \mathrm{GWh} / \mathrm{ano}$ ) ou pertencentes aos agentes concessionários, permissionários ou autorizados conectados diretamente no sistema elétrico de distribuição do comprador. Neste caso, é interessante observar, a diferenciação ocorrida com o self-dealing (geração para atendimento próprio) que não é mais admitido dentro do novo modelo.

A prerrogativa da compra desta energia advinda de Geração Distribuída (GD) é da distribuidora com a ressalva de que a composição tarifária terá como limite de repasse, um valor no máximo igual ou menor que a tarifa da última licitação de geração nova ocorrida no ambiente de contratação regulada com a premissa de que os custos evitados na distribuição incluindo a redução de perdas deverão ser suficientes para compensar eventuais diferenças na

\footnotetext{
${ }^{14}$ Pequeno Porte dentro do novo modelo são PCHs, pequenas centrais termelétricas, geração a partir de fontes renováveis e co-geração.
} 
tarifa de suprimento. Os contratos de backup são facultados ao titular da geração distribuída visando reduzir a exposição ao risco da distribuidora.

Esta contratação de energia elétrica proveniente de empreendimentos de geração distribuída será precedida de chamada pública promovida diretamente pelo agente de distribuição de forma a garantir publicidade, transparência e igualdade de acesso aos interessados. $\mathrm{O}$ montante total da energia elétrica contratada não poderá exceder a dez por cento da carga do agente de distribuição salvo os empreendimentos de GD que sejam próprios do distribuidor.

Se houver redução no custo de aquisição de energia, o repasse na tarifa dos consumidores finais será repassado com vistas à modicidade tarifária, no entanto, é vedado o repasse de custos adicionais. Além disso, a ANEEL definirá o limite de operação e indisponibilidade dos empreendimentos de GD considerando a sazonalidade.

Segundo o Prof. Adilson de Oliveira no Fórum de Cogeração realizado em 07/08/2003: “... o novo modelo cria novas barreiras à cogeração desestimulando as distribuidoras a cooperarem com os cogeradores ao introduzir penalidades por desvios na previsão de mercado e ao centralizar decisões de expansão, criando óbvias dificuldades para a geração descentralizada. ...” (Oliveira, 2003).

Já para a Pricewaterhouse Coopers na análise do novo modelo do setor elétrico (Pricewaterhouse Coopers, 2004), a cogeração deveria conter ações que objetivassem gerar resultados de curtíssimo prazo, quanto ao suprimento de energia elétrica necessário para atender às necessidades e expectativas de crescimento da demanda, criando um programa especial para o aproveitamento da capacidade de geração mal aproveitada na co-geração e visando intensificar o PROINFA.

\subsubsection{PROINFA}

O PROINFA foi instituído pela Lei $\mathrm{n}^{\mathrm{o}} 10.438$, de 26 de abril de 2002 e revisado pela Lei $\mathrm{n}^{\circ}$ 10.762, de 11 de novembro de 2003. A revisão previu mecanismos que visam incentivar a indústria nacional e a exclusão dos consumidores de baixa renda do pagamento do rateio da compra desta nova energia. O maior objetivo do Programa é a diversificação da matriz energética brasileira com a utilização de fontes renováveis de energia vislumbrando um 
aumento da participação da energia elétrica produzida com base nestas fontes, no Sistema Elétrico Interligado Nacional diversificando o número de agentes do setor.

Inicialmente, o Programa abrange 3.300 MW de capacidade instalada para os aproveitamentos energéticos selecionados sendo que as instalações deverão ter funcionamento previsto para até 30 de dezembro de 2008. Outro importante aspecto é a compra da energia assegurada pelas Centrais Elétricas Brasileiras S.A - ELETROBRÁS, por um período de 20 anos desde que os empreendedores que preencham todos os requisitos de habilitação pré-estabelecidos e selecionados de acordo com os procedimentos da Lei 10.438/02.

O Programa na sua concepção conta com o suporte do BNDES, que criou um programa de apoio a investimentos em fontes renováveis de energia elétrica. Com previsão de financiamento de até $70 \%$ do custo de implantação, excluindo apenas bens e serviços importados e a aquisição de terrenos. O aporte próprio do investidor será de $30 \%$ com amortização de dez anos e não-pagamento de juros durante a construção do empreendimento. Ao mesmo tempo, a ELETROBRÁS irá garantir ao empreendedor uma receita mínima de 70 $\%$ da energia contratada durante o período de financiamento e proteção integral quanto aos riscos de exposição do mercado de curto prazo, com contratos de duração de vinte anos.

O governo (MME, 2004) estima a geração de 150 mil empregos diretos e indiretos durante a construção e a operação dos empreendimentos, considerando o índice mínimo de nacionalização. Mecanismos com critérios de regionalização são previstos em Lei, permitindo os Estados que tenham seus projetos aprovados e licenciados a oportunidade de participarem do Programa.

O Poder Executivo entende o PROINFA como um instrumento de complementaridade energética sazonal à energia hidráulica. Na elaboração do Programa, previu-se a possibilidade de negócios de Certificação de Redução de Emissão de Carbono, nos termos do Protocolo de Quioto com a emissão evitada de 2,5 milhões de $\mathrm{tCO}_{2 \mathrm{eq}}$ /ano (MME, 2004) com a entrada destes empreendimentos.

A seguir, um breve resumo da legislação existente sobre o programa é apresentado sem a pretensão de esgotar o assunto em todas as suas dimensões.

\section{LEIS $N^{0} .10 .428 / 02$ E $10.762 / 03$}


- Os custos de natureza operacional, tributária e administrativa relativa à contratação da potência ou geração de energia elétrica serão rateados entre todas as classes de consumidores finais atendidos pelo SIN, de forma proporcional ao consumo individual. Este adicional tarifário é regulamentado pela ANEEL;

- Este rateio não se aplica ao consumidor classificado como da Subclasse Residencial Baixa Renda, Classe Residencial e na Classe Rural ${ }^{15}$ sob certas condições específicas de consumo mensal; e,

- O Programa tem o objetivo de aumentar a participação da energia elétrica produzia por empreendimentos de Produtores Independentes Autônomos, com as seguintes fontes: eólica, Pequenas Centrais Hidrelétricas - PCH e biomassa, no SIN.

\section{ETAPA I}

- Compra assegurada pela ELETROBRAS por 20 anos a partir da data de entrada em operação de 3.300 MW de capacidade, com os pisos e valores definidos em lei;

- A contratação deve ser distribuída igualmente em termos de capacidade instalada para cada uma das fontes participantes do programa com o valor econômico correspondente à tecnologia específica de cada fonte. O valor foi definido pelo MME, mas tendo como pisos 50,70 e $90 \%$ da tarifa média nacional de fornecimento ao consumidor final dos últimos 12 meses;

- A chamada Pública terá como critério as que estiverem com as Licenças Ambientais de Instalação - LI mais antigas, pela data de emissão;

- Limita-se por estado a contratação de até $20 \%$ das fontes eólica e biomassa e $15 \%$ para PCH. Concluída esta primeira rodada de seleção e não tendo ocorrido o total previsto de contratação com a presença de empreendimentos habilitados com LI válidas, o saldo remanescente por fonte será distribuído entre os Estados de localização desses empreendimentos, na proporção da oferta em kW com o mesmo critério de antiguidade de LI até a contratação do total previsto por fonte (1.100 MW);

\footnotetext{
${ }^{15}$ Atendido por circuito monofásico, consumo mensal inferior a $80 \mathrm{kWh} /$ mês ou situado entre 80 e $220 \mathrm{kWh} / \mathrm{mês}$, desde que se observe o máximo regional compreendido na faixa não sendo excluído, também por outros critérios fixados pela ANEEL.
} 
- Fabricantes de equipamentos de geração poderão participar diretamente se constituírem como PIA desde que o índice de nacionalização dos equipamentos e serviços seja, na primeira etapa, de, no mínimo, 60 \% em valor e, na segunda etapa, de, no mínimo 90 \% em valor; e,

- Caso não se atinja as cotas estipuladas, a diferença será distribuída nas demais fontes igualmente.

\section{ETAPA II}

- Após os $3.300 \mathrm{MW}$, as três fontes deverão atender $10 \%$ do consumo anual de energia elétrica do País, num prazo de até 20 anos, considerando os resultados da primeira etapa;

- O preço será o valor econômico correspondente à geração de energia competitiva, composta pelo custo médio ponderado de geração de novos aproveitamentos hidráulicos com potencia superior a $30 \mathrm{MW}$ e centrais termelétricas a gás natural, estipulado pelo MME;

- Aquisição será feita via programação anual de compra da energia elétrica, atendendo no mínimo $15 \%$ do incremento anual de energia elétrica fornecida ao mercado consumidor nacional, com mecanismos de compensação entre o previsto e o realizado para cada exercício; e,

- O PIA fará jus a um crédito complementar, que é a diferença entre o valor econômico correspondente à tecnologia específica de cada fonte, e o valor recebido da ELETROBRÁS.

\section{RESOLUÇÃO NORMATIVA Nº 127, DE 6 DE DEZEMBRO DE 2004}

-Procedimentos de rateio e definição das quotas de EE;

- Conta PROINFA - Administrada pela ELETROBRÁS;

- Consumidores livres e autoprodutores além de garantir o atendimento a $100 \%$ de sua carga, estão obrigados a participar do rateio do custo do PROINFA quando conectados às instalações do SIN;

- O rateio do custo e da EE proveniente do PROINFA irá abranger somente os agentes do SIN que comercializem energia com consumidor final, por meio de quotas o que excluí os consumidores atendidos via Sistema Isolado bem como os classificados na Subclasse Residencial Baixa Renda no SIN; 
- É interessante ressaltar que, no Plano Anual do PROINFA - PAP a ser elaborado pela ELETROBRÁS, deverá constar algumas previsões e demonstrativos, em especial, dos benefícios financeiros provenientes do Mecanismo de Desenvolvimento Limpo - MDL; e,

- Caso a geração mensal proveniente das fontes do PROINFA exceda as quotas estabelecidas no processo de sazonalização, o excedente será liquidado no mercado de curto prazo. Caso contrário, a ELETROBRÁS deverá adquirir energia no mercado de curto prazo como o atendimento do compromisso de entrega de energia com os agentes quotistas.

\section{LEI N ${ }^{0}$ 11.075, DE 30 DE DEZEMBRO DE 2004}

- Altera o prazo máximo para início da operação dos empreendimentos para 30 de dezembro de 2008 .

\section{RESOLUÇÃO NORMATIVA Nº5, DE 25 DE MAIO DE 2004}

- Estabelece a energia assegurada para PCH, Eólioelétricas e termoelétricas à biomassa;

Tabela 2.6. Energia assegurada: Relação das UTEs em expansão à base de biomassa. Fonte: RESOLUÇÃO NORMATIVA No 65, DE 25 DE MAIO DE 2004 - ANEXO III

\begin{tabular}{lrrr}
\hline \multicolumn{1}{c}{ Empreendimento } & $\begin{array}{c}\text { Antes } \\
\text { Ampliação } \\
\text { MWh/ano }\end{array}$ & $\begin{array}{c}\text { Após } \\
\text { Ampliação } \\
\text { MWh/ano }\end{array}$ & Variação \% \\
\hline UTE ALCON & 6.421 & 63.724 & 892,43 \\
UTE Ruette & 12.714 & 102.021 & 702,43 \\
UTE Jitituba & 40.391 & 101.278 & 150,74 \\
Sto. Antônio & 20.988 & 45.422 & 116,42 \\
UTE Seresta & 0 & 148.691 & 100,00 \\
UTE Canaã & 15.049 & 90.459 & 501,10 \\
UTE Sonora & 234.933 & 309.267 & 31,64 \\
UTE Sta. Elisa & 12.606 & 84.659 & 571,58 \\
UTE COOPERRUBI & 41.341 & 219.632 & 431,27 \\
UTE Costa Pinto & 29.517 & 156.529 & 430,30 \\
UTE Rafard & 15.799 & 114.118 & 622,31 \\
UTE Santa Helena & 19.787 & 100.881 & 409,83 \\
UTE São Francisco & 15.839 & 146.457 & 824,66 \\
UTE Diamante & 10.735 & 100.421 & 835,45 \\
UTE CRV & 7.021 & 34.182 & 386,85 \\
UTE DASA & 6.133 & 80.206 & 1207,78 \\
UTE Água Bonita & 0 & 21.900 & 100,00 \\
UTE Iolando Leite & 15.452 & 99.393 & 543,24 \\
UTE Pioneiros & 10.290 & 24.081 & 134,02 \\
UTE WD & 13.138 & 143.100 & 989,21 \\
UTE DISA & 16.504 & 77.310 & 368,43 \\
& & & continuação...
\end{tabular}


Tabela 2.6. Energia assegurada: Relação das UTEs em expansão à base de biomassa. Fonte: RESOLUÇÃO NORMATIVA No 65, DE 25 DE MAIO DE 2004 - ANEXO III continuação

\begin{tabular}{|c|c|c|c|}
\hline Empreendimento & $\begin{array}{c}\text { Antes } \\
\text { Ampliação } \\
\text { MWh/ano }\end{array}$ & $\begin{array}{c}\text { Após } \\
\text { Ampliação } \\
\text { MWh/ano }\end{array}$ & Variação \% \\
\hline UTE Santa Olinda & 22.171 & 133.586 & 502,53 \\
\hline UTE Brasilândia & 13.891 & 38.543 & 177,47 \\
\hline UTE Energia Ambiental & 0 & 12.727 & 100,00 \\
\hline UTE Energia Ambiental 2 & 22.341 & 146.616 & 556,26 \\
\hline UTE Ipaussu & 0 & 60.960 & 100,00 \\
\hline UTE GEEA Alegrete & 38.089 & 84.961 & 123,06 \\
\hline UTE Giasa II & 17.186 & 145.669 & 747,60 \\
\hline UTE Goiasa & 66.688 & 133.546 & 100,25 \\
\hline UTE Jalles Machado & 10.220 & 132.933 & 1200,71 \\
\hline UTE Lasa & 8.743 & 106.707 & 1120,48 \\
\hline UTE Nova Geração & 22.677 & 105.547 & 365,44 \\
\hline UTE Coruripe & 70.028 & 150.520 & 114,94 \\
\hline UTE USACIGA & 47.627 & 269.176 & 465,18 \\
\hline UTE Marituba & 28.959 & 72.397 & 150,00 \\
\hline UTE Sta. Terezinha & 11.514 & 136.531 & 1085,78 \\
\hline UTE Estivas & 46.380 & 144.518 & 211,60 \\
\hline UTE Goianésia & 10.930 & 32.608 & 198,33 \\
\hline UTE Mandu & 25.763 & 100.854 & 291,47 \\
\hline UTE Santo Ângelo & 11.585 & 68.706 & 493,06 \\
\hline UTE Baía Formosa & 21.211 & 92.720 & 337,13 \\
\hline UTE Delta & 118.653 & 189.631 & 59,82 \\
\hline UTE Volta Grande & 92.857 & 204.591 & 120,33 \\
\hline UTE Cerradinho & 111.645 & 270.559 & 142,34 \\
\hline UTE Agrovale & 20.798 & 28.468 & 36,88 \\
\hline UTE Ecoluz & 0 & 83.254 & 100,00 \\
\hline UTE Battistella & 27.316 & 131.439 & 381,18 \\
\hline UTE Winimport & 0 & 484 & 100,00 \\
\hline
\end{tabular}

\section{RESOLUÇÃO NORMATIVA Nº 62, DE 5 DE MAIO DE 2004}

- Estabelece procedimentos para o cálculo do montante correspondente à energia de referência de empreendimentos de geração de energia elétrica que participem no PROINFA;

- Para o caso de Usina Termelétrica - UTE a biomassa serão necessários os valores de:

a) potência instalada, em MW;

b) tipo de combustível a ser utilizado;

c) Poder calorífico inferior - PCI em kJ/kg, esperado para cada mês; 
d) valor esperado por mês, do consumo do combustível destinado a geração considerando as indisponibilidades forçadas e programadas; e,

e) rendimento elétrico global, razão entre energia elétrica gerada e a térmica do combustível com base no PCI e consumo do mesmo.

- Segue na mesma resolução as definições de cálculo para o fator de capacidade e energia de referência; $\mathrm{O}$ montante de energia de referencia que é o valor contratado pela ELETROBRAS.

\section{DECRETO No 5.025, DE 30 DE MARÇO DE 2004}

- Regulamenta o PROINFA na primeira etapa;

- Serão selecionados, um a um, os empreendimentos até atingirem a meta de 1.100 MW a serem instalados para a fonte, respeitando, concomitantemente, os limites por Estado de 220 MW para a fonte biomassa; Enquanto a meta não for atingida, a diferença será redistribuída aos Estados que apresentarem projetos habilitados e não-selecionados; e,

- O produtor de energia elétrica é responsável pelo acesso à rede e conexão aos sistemas de transmissão e distribuição. A existência de impossibilidade de acesso aos sistemas de transmissão ou distribuição até a data de funcionamento previsto será motivo de rescisão contratual e exclusão do empreendimento do PROINFA, primeira etapa.

\section{RESOLUÇÃO HOMOLOGATÓRIA Nº 57, DE 29 DE MARÇO DE 2004}

- Divulga o valor da Tarifa Média Nacional de Fornecimento ao Consumidor Final - TMF, relativo ao PROINFA. O valor é de $162,78 \mathrm{R} \$ / \mathrm{MWh}$;

\section{RESOLUÇÃO NORMATIVA Nº 56, DE 6 DE ABRIL DE 2004}

- Firma os procedimentos para acesso das centrais geradores participantes do PROINFA;

- As centrais geradoras do PROINFA deverão apresentar certidões de que irão atender os procedimentos de rede do ONS, das empresas transmissoras e distribuidoras;

- Acima de $230 \mathrm{kV}$ os acessos serão realizados nas permissionárias de transmissão, abaixo deste valor na concessionária ou permissionária de distribuição local; e, 
- A conexão será implementada visando à utilização racional dos sistemas, minimizados seus custos. Por tal motivo, o critério de mínimo custo global de interligação e reforços nas redes será empregado para as centrais geradoras do PROINFA.

\section{PORTARIA No ${ }^{0}$ 45/2004}

Fixa os valores econômicos de tecnologia por fonte. Para biomassa, em específico bagaço da cana-de-açúcar o VE é 93,77 R\$/MWh ${ }^{16}$ e o piso de 83,58 R $\$$ MWh (valores base de março de 2004). Estes valores são corrigidos pelo IGP-M.

\section{RESULTADOS FINAIS DO PROGRAMA}

Tabela 2.7. Resultados gerais do PROINFA - Etapa I.

\begin{tabular}{lrcrrr}
\hline $\begin{array}{c}\text { Aproveitamento } \\
\text { energético }\end{array}$ & $\begin{array}{c}\text { Quantidade de } \\
\text { Empreendimentos }\end{array}$ & $\begin{array}{c}\text { Potência } \\
\text { Contratada } \\
\text { MW }\end{array}$ & $\begin{array}{c}\text { Contrato } \\
\mathbf{1 0}^{\mathbf{6}} \mathbf{U S \$} / \mathbf{a n o}\end{array}$ & $\begin{array}{c}\text { Investimento } \\
\mathbf{1 0}^{\mathbf{6}} \mathbf{U S \$}\end{array}$ & $\begin{array}{c}\text { Mestimento } \\
\text { Móndio por } \\
\text { Potência } \\
\text { Gerada } \\
\text { US\$/kW }\end{array}$ \\
\hline PCH & 63,0 & 1193,0 & 320,7 & 1440,0 & 1207,0 \\
Eólica & 54,0 & 1423,0 & 314,6 & 2212,0 & 1554,5 \\
Biomassa & 27,0 & 685,2 & 91,9 & 404,0 & 589,6 \\
Total & 144,0 & 3301,2 & 727,2 & 4056,0 & 1228,6 \\
\hline
\end{tabular}

Tabela 2.8. Participação por Estado no PROINFA, fonte biomassa. Fonte: Relação de

\begin{tabular}{crr} 
Empreendimentos Contratados - Site PROIN & Pricipação \\
\hline Estado & Potência MW & Partici, \\
\hline SP & 271,52 & $39,62 \%$ \\
GO & 79,52 & $11,60 \%$ \\
PR & 105,1 & $15,34 \%$ \\
MS & 49,4 & $7,21 \%$ \\
PE & 63,2 & $9,22 \%$ \\
PB & 20 & $2,92 \%$ \\
AL & 31 & $4,52 \%$ \\
MG & 30 & $4,38 \%$ \\
ES & 30,5 & $4,45 \%$ \\
Total & 685,24 & \\
\hline
\end{tabular}

A Resolução $n^{\circ}$. 56/04, em parte, é motivada pelos problemas que podem ocorrer na conexão dos empreendimentos à rede, tais como: curto-circuito por excesso de carga ou limitação na transmissão além de visar tornar o processo de integração transparente. A metodologia para avaliar a interligação priorizará a conexão de menor custo global para a rede.

\footnotetext{
${ }^{16}$ Valor definido para a área II - demais áreas do país que é a área de interesse deste trabalho. Para as áreas de abrangência das extintas SUDAM e SUDENE, o VE é superior ao apresentado, 119,61 R\$/MWh.
} 
Os valores econômicos para cada fonte foram publicados pelo MME por portaria sendo estes inferiores aos valores que o próprio governo apresentou na consulta pública realizada anteriormente. Tal mudança, não inviabilizou o programa, mas segundo a Agência Canal Energia, na reportagem veiculada sobre o PROINFA no dia 25/06/2004, reduziu a atratividade para os investidores. Para efeitos comparativos, os valores encaminhados na consulta pública são 119,61 e 89,59 R $\$$ /MWh para VE e piso para o bagaço respectivamente. Outra crítica apresentada por Coelho (2005) é que não houve distinção nos VEs por tecnologia perdendo-se assim uma forma de induzir o mercado à adoção, troca ou melhoras das rotas tecnológicas em conversão de energia para a fonte biomassa nos combustíveis considerados pelo Programa (setores arrozeiro, madeireiro, sucroalcooleiro e biogás).

A Tabela 2.8. demonstra a participação preponderante do Estado de São Paulo para a fonte biomassa no PROINFA com quase $40 \%$ na potência instalada. Ressalta-se que dos 271,52 MW disponibilizados pelo Estado, a totalidade tem como fonte o bagaço da cana-de-açúcar (ANEEL, 2006).

Da Tabela 2.6. que trata da energia assegurada para usinas que participaram do processo de seleção e habilitação do PROINFA é evidenciado o grande potencial que as Usinas Sucroalcooleiras possuem para geração de excedentes de energia elétrica, bastando observar os percentuais envolvidos entre a energia antes da ampliação (energia de referência) e os valores após a ampliação.

Os levantamentos apresentados abrangem as informações tanto da primeira chamada quanto da segunda chamada. As UTEs e potências contabilizadas para a formulação da Tabela 2.8. tiveram como base os empreendedores que efetivamente assinaram o contrato de compra e venda de energia elétrica com a ELETROBRÁS. A diferença entre 1.100 MW previstos para esta fonte e os 685,24 MW efetivamente contratados foram redistribuídos para os aproveitamentos Eólioelétricos e PCHs concluindo a etapa de contratação dos $3.300 \mathrm{MW}$ previstos no PROINFA em Lei.

As reclassificações e outras chamadas tiveram origem com problemas nas documentações apresentadas à ELETROBRÁS, questionamentos de ordem jurídica, problemas com licenciamento ambiental, desclassificações técnicas após reavaliações e desistências por parte dos empreendedores no momento da assinatura dos contratos. Ressalta-se que para a fonte 
biomassa, apenas 569,5 MW foram apresentados na primeira chamada do Programa, o que implicou na segunda chamada pública de empreendimentos para esta fonte.

Em NAE (2005) algumas barreiras à geração de eletricidade com a biomassa da cana são apontadas: a cultura de mercado da indústria de cana-de-açúcar é baseada em duas commodities - açúcar e álcool. Demandando a necessidade de incentivos para essa indústria investir na geração de energia elétrica, uma vez que esse produto não pode ser estocado para especulações de preço. Além disso, a negociação da venda da energia requer outro tipo de conhecimento, que não faz parte do cotidiano da indústria sucroalcooleira. $\mathrm{O}$ faturamento com a venda de eletricidade excedente representaria $4,60 \mathrm{R} \$ / t_{\text {cana }}$ e com açúcar e álcool é de cerca

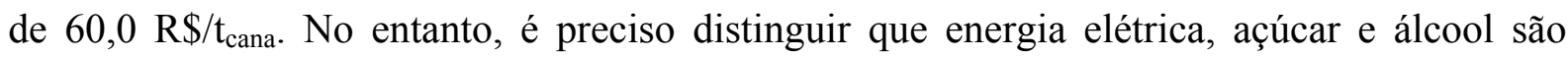
diferentes commodities, com diferentes preços de mercado e que uma não impede a outra, mas sim se complementam. Dados do MME indicam que a taxa interna de retorno (TIR) dos projetos de geração elétrica a partir do bagaço de cana se situa em torno de 14,89 \% (NAE, 2005).

Ao mesmo tempo, a tabela 2.7. mostra que os investimentos previstos por $\mathrm{kW}$ gerado de eletricidade para o aproveitamento biomassa, onde predomina o setor sucroalcooleiro, são menores quando comparados com as PCHs e aproveitamentos eólicos. Tal fato, quando trazido à luz da segunda etapa do PROINFA indica uma vantagem comparativa considerando que o VE a ser utilizado será o da energia gerada competitiva. Esta consideração leva em conta que o VE é composto por centrais geradoras acima de 30 MW num mix entre hidrelétricas e termelétricas à gás. Quando vistas num cenário de médio/longo prazos aonde o preço e o suprimento de gás natural vêm sofrendo alterações diante da nacionalização do gás boliviano, gás este que supre grande parte do mercado de GN do país, e da previsão de entrada dos empreendimentos hidrelétricos de grande porte tais como o Complexo do Rio Madeira e Belo Monte nos próximos leilões de energia nova podem implicar em referenciais de VE acima dos existentes.

Contudo, destaca-se que o governo incluiu no arcabouço regulatório do PROINFA a absorção das possíveis receitas oriundas da venda de certificados de redução de emissão advindas do $\mathrm{MDL}^{17}$. O que reduz ainda mais a atratividade na participação do Programa.

\footnotetext{
${ }^{17}$ A definição dos certificados de redução de emissão será detalhada mais adiante neste trabalho.
} 


\subsubsection{MDL}

Um assunto que tem ocupado a mídia com freqüência é o efeito estufa. Este efeito, em alguns casos, é tratado de forma equivocada visto que sem este, a temperatura média do planeta seria muito baixa. No entanto, a intensificação deste efeito pode representar um grave problema para a humanidade. As ações decorrentes das atividades econômicas e industriais têm provocado alterações na biosfera, resultando, aproximadamente, na duplicação da concentração de Gases de Efeito Estufa ${ }^{18}$ (GEE) durante o período de 1750 a 1998 além do fato que esta alteração da concentração dos GEE poderá desencadear um aumento na temperatura média do planeta entre 1,4 e $5,8^{\circ} \mathrm{C}$ nos próximos cem anos (IPCC, 2004).

Durante a Conferência das Nações Unidas sobre o Meio Ambiente e o Desenvolvimento em 1992 foi estabelecida a Convenção Quadro das Nações Unidas sobre Mudanças Climáticas (CQNUMC), sendo este o primeiro passo visando à estabilização das concentrações de gases de efeito estufa na atmosfera num nível que impeça uma interferência antrópica perigosa no sistema climático. A CQNUMC entrou em vigor em 1994.

Desde a sua entrada, as partes envolvidas têm se reunido para discutir o assunto e tentar desenvolver soluções para o problema apresentado, estes encontros foram denominados Conferência das Partes (COP). Cinco anos depois, a Terceira Conferência das Partes (COP-3) criou o Protocolo de Quioto o qual determina o estabelecimento de compromissos para atingir uma meta de redução média de 5,2 \% das emissões dos GEE em relação ao ano de 1990 durante o período de 2008 - 2012 (denominado como primeiro período de compromisso).

Os países participantes foram classificados como Partes, sendo divididos em Partes Anexo I e Partes Não Anexo I. Essa divisão tem como objetivo separar alguns critérios, sobretudo a responsabilidade pelo aumento da concentração atmosférica de GEE.

Os países em desenvolvimento (não Anexo I) estão isentos de compromissos quantificados de redução de GEE no âmbito do Protocolo de Quioto por conta do princípio da responsabilidade comum. Este princípio é a responsabilidade de todos com o aquecimento global. E a diferenciação possui origens históricas, pois os países do Anexo I começaram a contribuir com a evolução na emissão dos GEEs desde a Revolução Industrial, enquanto os países em

\footnotetext{
${ }^{18}$ A CQNUMC define gases de efeito estufa como os constituintes gasosos da atmosfera, naturais e antrópicos, que absorvam e reemitam radiação infravermelha. O protocolo de Quioto engloba como GEE, em seu Anexo A, os gases: dióxido de carbono $\left(\mathrm{CO}_{2}\right)$, metano $\left(\mathrm{CH}_{4}\right)$, ódixo nitroso $\left(\mathrm{N}_{2} \mathrm{O}\right)$, Hexafluoreto de enxofre $\left(\mathrm{SF}_{6}\right)$ e as famílias de gases hidrofluorcarbonos (HFCs) e perfluorcarbonos (PFCs).
} 
desenvolvimento iniciaram significativamente suas contribuições a partir da década de 1960, quando a industrialização chegou a estes países. Estima-se que os paises do Anexo I emitiram 70 \% a mais que os países que não estão no Anexo I (Oliveira, 2004).

Uma das resoluções determinadas durante as COP's foi a quantificação das emissões dos GEE. Sabe-se que o gás carbônico $\left(\mathrm{CO}_{2}\right)$ é um dos principais GEE e diante disso, um modelo para equalizar as emissões dos demais com base no $\mathrm{CO}_{2}$ como referência foi desenvolvido, sendo que todas as unidades estarão em toneladas métricas. Este modelo de conversão baseiase no índice de Potencial de Aquecimento Global (Global Warming Potential - GWP), divulgado pelo Intergovernmental Panel on Climate Chance (IPCC) e utilizado para uniformizar as quantidades dos diversos gases de feito estufa em termos de gás carbônico equivalente possibilitando que as reduções de diferentes gases sejam somadas. O GWP deve ser utilizado para as contabilizações do primeiro período de compromisso.

O Protocolo de Quioto estabeleceu ainda como complementação às medidas e políticas domésticas das Partes Anexo I, mecanismos de flexibilização adicionais de implementação, permitindo que a redução das emissões e/ou aumento na remoção de GEE seja, em parte, obtida além de suas fronteiras nacionais no cumprimento de suas metas. Estes mecanismos adicionais incluem:

a) Implementação Conjunta;

b) Comércio de Emissões; e,

c) Mecanismo de Desenvolvimento Limpo.

A implementação conjunta e o comércio de emissões são atividades restritas aos países do Anexo I e com metas de redução estabelecidas pelo Anexo B do Protocolo. A implementação conjunta visa à transferência e/ou aquisição de unidades de redução de emissões resultantes de projetos que reduzam emissões antrópicas em vários setores da economia. A maior diferença entre estes dois mecanismos está justamente no fato de que o primeiro envolve o estabelecimento de projetos de um país em outro, enquanto que o segundo permite negociações financeiras das unidades de redução de $\mathrm{CO}_{2}$ equivalente sem envolver os projetos diretamente.

Já o Mecanismo de Desenvolvimento Limpo, também auxilia as partes incluídas no Anexo I a cumprirem os compromissos quantificados. Porém uma grande diferença em relação aos 
outros dois mecanismos está no envolvimento dos países que não possuem compromissos quantitativos de reduzir as emissões de gases de efeito estufa, ou seja, aqueles não incluídos no Anexo I. Desta forma, os países em desenvolvimento podem receber os projetos de redução de emissões ou absorção de GEE. Outra diferença reside no fato de que o objetivo do MDL também visa assistir os países em desenvolvimento no que se refere ao desenvolvimento sustentável e transferência de tecnologia, além de, ao mesmo tempo auxiliar na contribuição do objetivo final da convenção. Com relação ao desenvolvimento sustentável, vale destacar que este é um dos critérios para elegibilidade de um projeto de $M D L$.

Ainda com relação ao desenvolvimento sustentável, o Ministério de Meio Ambiente (MMA) sugere que, no Brasil os projetos MDL estejam voltados, prioritariamente para os setores que empreguem tecnologias e técnicas que contribuam para: eficiência energética no uso final (conservação de energia) e na expansão da oferta de energia (o que inclui: possíveis reduções das perdas na cadeia de produção, transporte e armazenamento de energia); suprimento de serviços energéticos através de energia renovável ou do uso de gás natural em substituição aos combustíveis fosseis com maior teor de carbono; aproveitamentos energéticos de metano provenientes da disposição de resíduos, entre outros.

Por fim, é necessário esclarecer que os países do Anexo I, com metas de redução de emissões estabelecidas, participam do procedimento de MDL por meio da utilização das Reduções Certificadas de Emissões (RCEs) resultantes das atividades dos projetos, como forma de atuarem como investidores nos projetos realizados nos países hospedeiros (não Anexo I). A quantidade de RCEs geradas pelo projeto é determinada ao se comparar as emissões do mesmo com as estimativas do que aconteceria na ausência da sua atividade. $O$ cenário configurado pela ausência do projeto MDL é o chamado cenário de referência ou linha de base. Desta forma, o setor privado tem grande oportunidade de participação, pois há fluxos de investimentos e mecanismos de mercado concebido para efetiva atuação das partes interessadas.

A estrutura institucional envolvida no desenvolvimento de projetos MDL, não será apresentada neste trabalho visto que os pontos essenciais são a descrição dos mecanismos previstos pelo Protocolo de Quioto para contextualização do Mecanismo de Desenvolvimento Limpo e do ciclo do projeto para se compreender a importância da discussão das metodologias de linha de base e quantificação das emissões evitadas dentro das etapas de um projeto de MDL. 
Com relação ao ciclo do Projeto MDL, ele é composto de forma bem simplificada, necessariamente por:

1. Documento de Concepção de Projeto - descreve a metodologia de linha de base bem como a forma de cálculo da redução de emissões de GEE nos limites de projeto e fora deste permitindo o cálculo das fugas. O documento deverá apresentar um plano de monitoramento, avaliação de possíveis impactos ambientais; e justificativa para adicionalidade da atividade de projeto;

2. Validação / Aprovação - nesta etapa, a Entidade Operacional Designada irá avaliar e validar a atividade de projeto MDL, checando se os pontos citados acima foram incluídos e avaliados no projeto; A documentação é disponibilizada ao público e aberta para comentários;

3. Registro - onde o projeto MDL é formalmente aceito pelo Conselho Executivo;

4. Monitoramento - o método de monitoramento deverá estar de acordo com a metodologia previamente aprovada ou, se utilizada nova metodologia deverá ser aprovada ou sua aplicação ter se mostrado bem sucedida em outra aplicação;

5. Verificação / Certificação - a Entidade Operacional Designada no país verificará se as reduções de emissões de gases de efeito estufa monitoradas ocorreram como resultado da atividade do projeto MDL, isto é, deverá relatar por escrito que o projeto de fato atingiu as reduções declaradas no período; e,

6. Emissão e aprovação das RCEs.

Em suma a este capítulo, o Estado de São Paulo é o maior produtor de cana-de-açúcar e seus produtos (açúcar / álcool) do país e, apresenta o maior potencial para aproveitamento das políticas de incentivo às fontes renováveis de energia, quando considerada a biomassa, e deslocamento de energia térmica e elétrica implicando na possibilidade de inserção dentro de projetos MDL. Esta forma de aproveitamento assume importância quando considerada a complementaridade possível no suprimento de eletricidade para o SIN, apresentando a relevância do setor sucroalcooleiro na geração de eletricidade no país e no estado com uma análise calcada nos balanço energético nacional e estadual. Outro aspecto relevante é a possível melhora nos índices de eficiência energética das unidades produtivas. 
Com relação à participação na geração de energia elétrica do Brasil por unidade de federação, o Estado de São Paulo é o segundo maior gerador. Destacou-se que o setor sucroalcooleiro possui a maior participação na autogeração de eletricidade no Brasil, por setores da economia. Foi evidenciado, também, pelas séries históricas de produção e consumo de energia final, a relação de dependência energética do Estado com os aproveitamentos energéticos oriundos da cana-de-açúcar.

Paralelamente, procurou-se apresentar os mecanismos previstos no Protocolo de Quioto, contextualizando o MDL. Este mecanismo será enfatizado e desenvolvido neste trabalho sob a ótica do desenvolvimento sustentável e das externalidades do ciclo produtivo da cana-deaçúcar. A forma com que se dará esta avaliação e sob quais aspectos, serão vistos adiante em capítulo específico sobre o tema. 


\section{A INDÚSTRIA SUCROALCOOLEIRA E O MECANISMO DE DESENVOLVIMENTO LIMPO}

Este capítulo visa situar a posição da indústria sucroalcooleira com relação à carteira de projetos no país e apresentar as principais metodologias para determinação dos cenários de base, quantificação das emissões evitadas nos certificados de redução de emissão que irão culminar, dentro dos moldes do MDL, em reduções certificadas de emissões (RCE).

Para tal, foi realizada uma pesquisa nas referências internacionais e, principalmente, no site da UNFCCC onde estão dispostos tantos os projetos, quanto às metodologias, comentários, relatórios de análise e informações sobre o monitoramento. O critério utilizado para desenvolver esta seção foram os documentos aprovados pelo Comitê Executivo do MDL para empreendimentos do setor sucroalcooleiro.

Até a data de 19 de outubro de 2006, um total de 1308 projetos estavam em alguma fase do ciclo de projetos do MDL. Deste quantitativo, 382 já registrados pelo Conselho Executivo do MDL e 926 em outras fases do ciclo. Como pode ser visto nas Figuras 3.1. e 3.2., o Brasil ocupa o $2^{\circ}$ lugar em número de atividades de projeto, com 197 projetos o que representa $15 \%$ do total de projetos no mundo, sendo que em primeiro lugar encontra-se a Índia com 470 e, em terceiro, a China com 181 projetos.

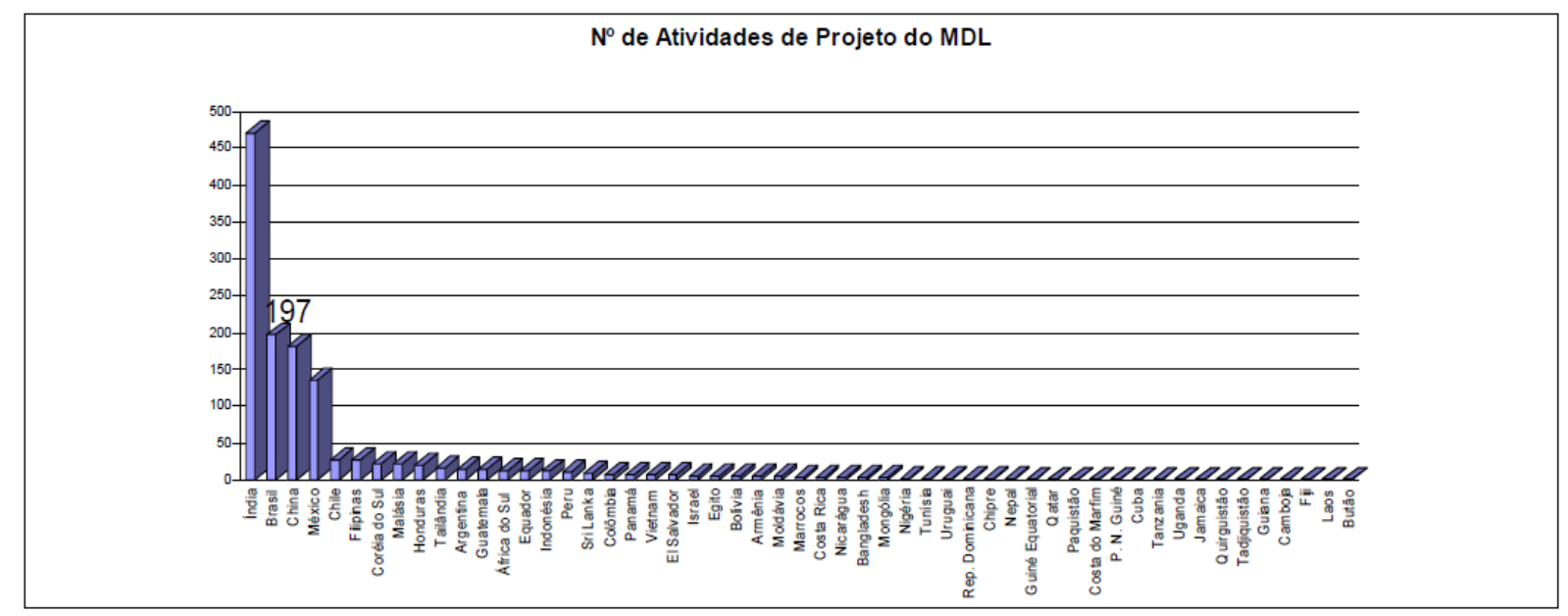

Figura 3.1. Número de atividades de projeto no sistema do MDL. Fonte: MCT, 2006

Uma atividade de projeto entra no sistema do MDL quando o seu documento de concepção de projeto (DCP) correspondente é submetido para validação a uma Entidade Operacional 
Designada (EOD). Ao completar o ciclo de validação, aprovação e registro, a atividade registrada torna-se efetivamente uma atividade de projeto no âmbito do MDL. Diante deste critério de avaliação dos projetos, as Figuras 3.1. e 3.2. apresentam o status atual das atividades de projeto ainda em estágio de validação, aprovação e registro.

\section{Total de Atividades de Projeto do MDL no Mundo} 1308
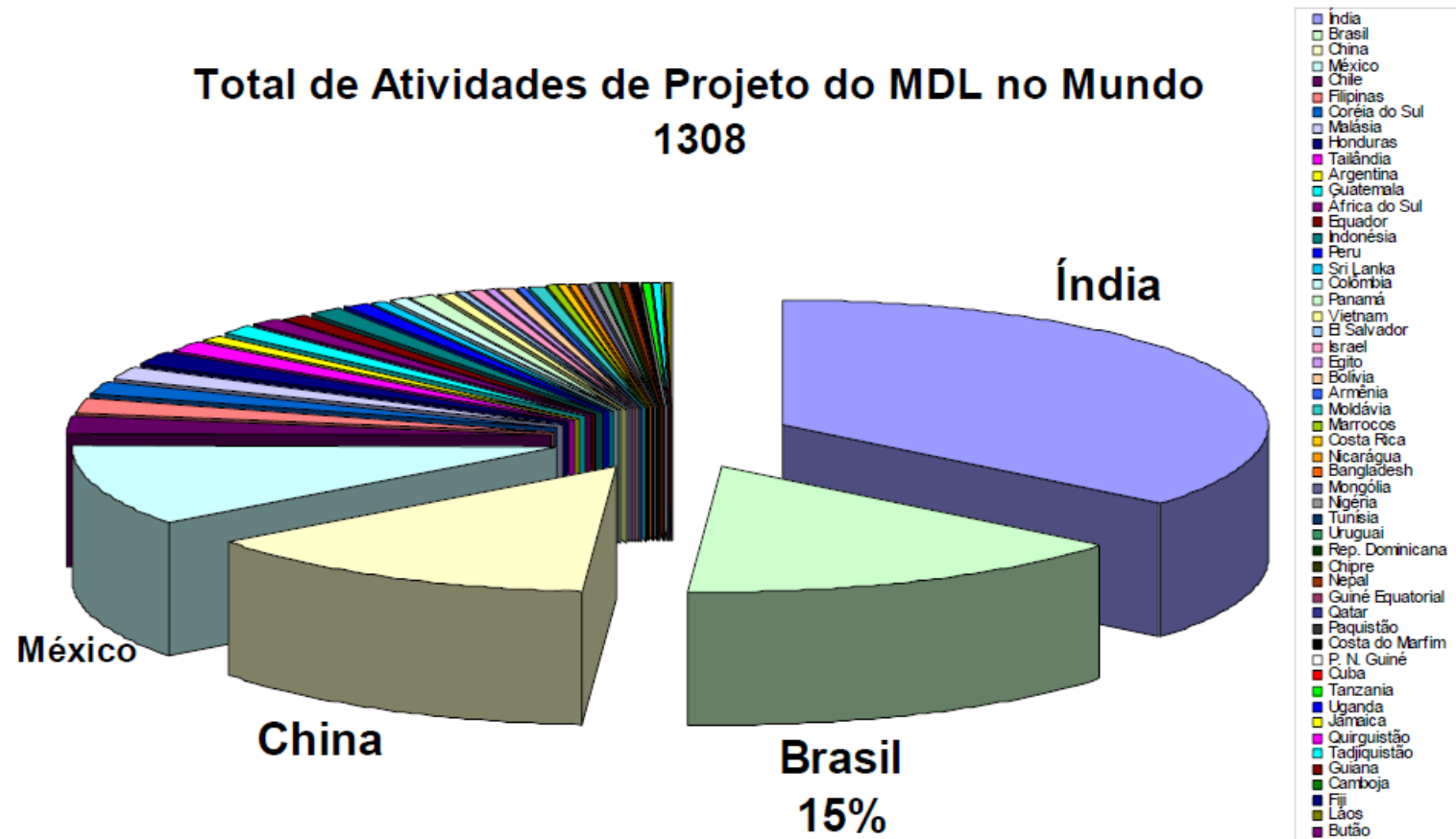

Figura 3.2. Total de Atividades de Projeto MDL no Mundo. Fonte: MCT, 2006

Referente à redução das emissões projetadas para o primeiro período de obtenção de créditos, o país que possui a maior participação é a China com 675 milhões $\mathrm{tCO}_{2 \mathrm{eq}}$ a serem reduzidas, o que representa cerca de trinta e cinco por cento do total das projeções, seguida pela Índia com 456 milhões $\mathrm{tCO}_{2 \text { eq }}$ com vinte e quatro por cento e o Brasil na terceira posição, sendo responsável pela redução de 190 milhões $\mathrm{tCO}_{2 \mathrm{eq}}$ com dez por cento da participação. Estas posições permanecem mesmo quando se analisa sob a perspectiva das emissões reduzidas anualmente.

Quando se faz um balanço das reduções das emissões brasileiras, o gás carbônico é o mais relevante, seguido do metano e pelo óxido nitroso $\left(\mathrm{N}_{2} 0\right)$ respectivamente. A predominância do $\mathrm{CO}_{2}$ se explica pelas atividades de projeto apresentadas pelo setor energético.

A predominância das atividades de projeto no setor energético se deve, predominantemente, ao aproveitamento de fontes renováveis de energia e uma maior ênfase da indústria neste setor. Tanto é desta forma, que no levantamento apresentado pelo MCT (MCT, 2006), a 
Indústria Energética possui $31 \%$ na participação dos projetos brasileiros quando analisados pelo viés setorial, seguida da energia renovável com $22 \%$ e aterro sanitário com $12 \%$.

Quanto à escala das atividades de projeto no Brasil, os projetos de larga escala se destacam com uma participação de $61 \%$ do total $^{19}$.

Cruzando as informações setoriais com as de redução em emissões, a área de geração de eletricidade e de cogeração com biomassa representa a maioria das atividades de projeto, com $53 \%$ do total. No entanto, estes projetos reduzem $24 \%$ do total das emissões. Os projetos de emissões reduzidas por aterros sanitários e dióxido de nitrogênio alcançam um total de $62 \%$ do total das reduções.

No Brasil, as atividades estão distribuídas, por estado, predominantemente em São Paulo e Minas Gerais, com $25 \%$ e $13 \%$ respectivamente, seguidos do Rio Grande do Sul e Mato Grosso, juntos com 8 \%. Destaque para o Estado de São Paulo que, como se pode observar, responde por um quarto das atividades de projeto no país.

\subsection{PARTICIPAÇÃO DE EMPREENDIMENTOS COM BASE NA BIOMASSA DA CANA-DE-AÇÚCAR NO BRASIL}
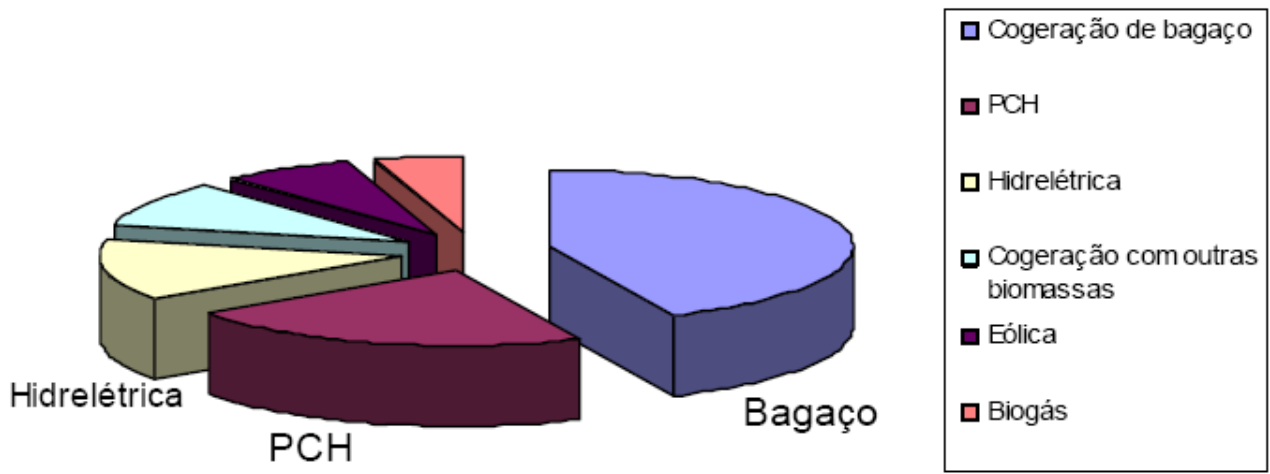

Figura 3.3. Capacidade instalada MW das atividades de projeto aprovadas. Total de 2.163,73 MW. Fonte: MCT, 2006

\footnotetext{
${ }^{19}$ Segundo o Acordo de Marraqueche: projetos de pequena escala são atividades de energia renovável com capacidade máxima de geração até $15 \mathrm{MW}$; projetos de eficiência energética que reduzam o consumo de energia tanto do lado da oferta e/ou da demanda até $15 \mathrm{MW}$; outras atividades que reduzam as emissões antrópicas de $\mathrm{CO}_{2}$ / ano em 15 toneladas equivalentes; - Projetos de larga escala são todas as outras atividades que não se enquadra nesta definição de pequena escala.
} 
Da Figura 3.3., faz-se uma análise da capacidade total instalada das atividades de projeto na área energética que estão atualmente aprovados. Avaliando-se a distribuição por forma de geração de energia, o bagaço de cana-de-açúcar tem 43,35\% da participação total com 938 $M W$, seguido pela PCHs com 454 MW e hidrelétricas com 290 MW.

\subsection{Metodologias QUANTITATIVAs PARA AVAliaÇão de PRojetos MDL COM ÊNFASE NO SETOR SUCROALCOOLEIRO}

Esta seção trata das metodologias submetidas e aprovadas pelo UNFCC para quantificação das emissões evitadas na avaliação de projetos de MDL com foco na indústria sucroalcooleira.

Estas metodologias são utilizadas para a proposição de novos empreendimentos ou servem como base para novas propostas metodológicas que, neste caso deverão ser avaliadas e aprovadas pelo Comitê Executivo do MDL.

\subsubsection{METODOLOGIAS APROVADAS ATUALMENTE}

Para este trabalho, realizou-se uma pesquisa no website ${ }^{20}$ do Mecanismo de Desenvolvimento Limpo, mantido pela UNFCCC e da Comissão Interministerial de Mudança Global do Clima hospedado no website do Ministério de Ciência \& Tecnologia. Nestes locais estão disponíveis todas as propostas de projeto, discussões, metodologias para quantificação e dos sistemas de monitoramento e controle de qualidade tanto na esfera mundial (CDM/UNFCCC) quanto dos projetos no país (CIMGC/MCT). Foram pesquisadas metodologias propostas e aprovadas para empreendimentos que envolvam o segmento industrial do açúcar e álcool.

Deste levantamento, duas metodologias foram destacadas, são elas:

1) "Avoided methane emissions from organic waste-water treatment" - " Emissões evitadas pelo tratamento orgânico de resíduos líquidos" AM0013 - Versão 03 de 19 de maio de 2006 - Esta metodologia é a consolidação de duas metodologias, a

\footnotetext{
${ }^{20}$ Até a data de 17/12/2006.
} 
saber: projeto de tratamento anaeróbio de vinhaça; projeto de extração de metano e geração de eletricidade;

2) "Consolidated baseline methodology for grid-connected electricity generation from biomass residues" - "Metodologia consolidada de linha base para geração de eletricidade de resíduos de biomassa conectados ao sistema interligado de energia elétrica" ACM0006 - Versão 03 de 19 de maio de 2006 - Esta metodologia é a consolidação de cinco propostas de projeto e metodológicas. Dentre elas, destacase o Projeto de Cogeração com Bagaço da Usina Vale do Rosário (UVR) e o de substituição de combustível pelo Nobracel Celulose e Papel ambas situadas no Brasil. Cabe ressaltar que a metodologia apresentada pelo projeto da UVR foi a primeira metodologia aprovada para cogeração com bagaço de cana-de-açúcar conhecida como AM0015 "Bagasse-based cogeneration connected to an electricity grid"; a metodologia ACM0006 nada mais fez que expandir a AM0015 juntamente com informações de mais outras quatro metodologias quanto aos combustíveis, isto é, os tipos de resíduos de biomassa;

A intenção, desta forma, é abranger tanto o aproveitamento dos resíduos da biomassa da cana de açúcar ${ }^{21}$ quanto o possível aproveitamento da vinhaça gerada pela cadeia produtiva da indústria sucroalcooleira. Explorando desta forma as opções de geração de eletricidade e calor que se enquadrem no âmbito do mecanismo de desenvolvimento limpo. O aproveitamento da vinhaça para fins energéticos é incipiente quando comparado ao do bagaço de cana.

É primordial salientar que estas metodologias estão calcadas para os casos que as Usinas em questão estejam conectadas ao Sistema Interligado Nacional (SIN) isto é, na Rede Básica ou na própria rede de subtransmissão e distribuição dependendo da classe de tensão que estas instalações estejam ligadas. Caso contrário, não haverá deslocamento das emissões provenientes da geração de energia elétrica por outras fontes presentes na matriz de eletricidade do Brasil.

\footnotetext{
${ }^{21}$ Entenda-se aqui no contexto deste trabalho o termo resíduo da biomassa como sendo o bagaço, pontas e palha. Pela metodologia, resíduo de biomassa é definido como toda biomassa que seja subproduto, resíduo ou desperdício de atividades como agricultura, manejo florestal e indústrias vinculadas. A metodologia frisa que isto não excluí resíduos municipais ou que contenham materiais biodegradáveis e/ou fósseis. Da mesma forma, entenda-se no âmbito deste trabalho como efluente e resíduo do sistema a vinhaça advinda do processamento da cana-de-açúcar.
} 


\subsubsection{DESENVOLVIMENTO DAS METODOLOGIAS}

Sendo as metodologias de quantificação já selecionadas, a análise será segmentada da seguinte forma: uma apresentação dos itens comuns às duas metodologias, seguido das especificidades de indicadas à parte nos subitens seguintes.

\subsubsection{CORPO COMUM ÀS METODOLOGIAS}

Conforme o documento de "CDM Modalities and Procedures",22 as metodologias possíveis para definição da linha de base são:

a) As emissões atuais ou históricas existentes, conforme o caso; ou,

b) As emissões de uma tecnologia que represente um curso economicamente atrativo de ação, levando em conta as barreiras para o investimento; ou,

c) A média das emissões de atividades de projeto similares realizadas nos cinco anos anteriores, em circunstâncias sociais, econômicas, ambientais e tecnológicas similares, e cujo desempenho esteja entre os primeiros 20 por cento de sua categoria.

Ambas as metodologias selecionaram a opção “a)" como modalidade e procedimento. Já a metodologia para resíduos de biomassa, admite também, a opção “b)”.

\section{ADICIONALIDADE}

A metodologia apresentada somente é válida se houver aprovação pela Comissão Executiva das ferramentas utilizadas para demonstração da adicionalidade.

A adicionalidade é um critério fundamental para que uma determinada atividade de projeto seja elegível ao MDL. Consiste na redução das emissões dos GEE ou no aumento das remoções de $\mathrm{CO}_{2}$ de forma adicional ao o que ocorreria na ausência de tal atividade.

Para o caso do resíduo da biomassa, outras questões também devem ser abordadas para uma completa avaliação da adicionalidade na ausência do projeto proposto:

a) como a eletricidade será gerada;

\footnotetext{
${ }^{22} \mathrm{O}$ texto trata das modalidades e procedimentos para o MDL contidos no Anexo da Decisão 17/CP.7, que por sua vez está contida no documento FCCC/CP/2001/13. O referido trata de: definições, regras, Conselho Executivo, credenciamento e designação de entidades operacionais, requerimentos para participação, validação, registro, monitoração, verificação e certificação de projetos e emissão de RCE's
} 
b) a destinação da biomassa; e,

c) a forma como o calor será gerado.

Para Leme et al (2004), o PROINFA não deve interferir negativamente na adicionalidade dos projetos de cogeração com bagaço de cana, por duas razões principais: ainda há barreiras para implementação desse tipo de projeto no país e a percepção sobre este tipo de geração é de risco e com pouca atratividade econômica. Além disso, há um potencial de expansão do setor superior à capacidade prevista na primeira etapa do PROINFA, potencial este que depende de instrumentos adequados de incentivo para serem concretizados. Neste ponto, entende-se que o MDL pode se mostrar relevante.

\subsubsection{METODOLOGIA - BAGAÇO \& RESÍDUOS DE BIOMASSA}

\section{APLICABILIDADE}

Esta metodologia é aplicável para resíduos de biomassa utilizados para geração de eletricidade, incluindo plantas de cogeração. Ela é aplicável nos seguintes casos:

- Instalação de plantas de geração em locais onde não há geração de eletricidade;

- Instalação de outra unidade de geração próxima a existente que utilize combustível fóssil ou o mesmo resíduo de biomassa já utilizado;

- Melhora na eficiência energética da planta;

- Substituição de combustível fóssil por resíduo de biomassa; e,

- Desde que não eleve a capacidade de processamento bruto da biomassa e/ou não altere substancialmente o processo produtivo.

Além dos casos acima citados, outros requisitos são exigidos:

- O resíduo de biomassa deverá ser o combustível predominante na planta não sendo utilizada outra fonte como combustível eventual (prevê-se a co-queima de combustíveis fósseis por curtos períodos de tempo); 
- O uso do resíduo na geração de eletricidade não deverá resultar em aumento na área plantada e no volume de processamento da indústria;

- A biomassa não deverá ser armazenada por mais de ano, se for utilizada para o projeto; e,

- Não deverá existir um gasto significativo de energia para a obtenção do resíduo da biomassa, exceto para o seu transporte, antes de ser empregado para combustão.

\section{OS LIMITES DO PROJETO}

A planta de geração de eletricidade deverá também, localizar-se em área agroindustrial ou receber suprimentos dos resíduos de biomassa de regiões próximas.

A extensão da área do projeto deve contemplar todos os locais por onde a cana-de-açúcar, dentro da propriedade, for tratada incluindo as plantas de geração de eletricidade desde que elas estejam conectadas ao sistema elétrico.

A definição do limite do projeto é importante para que haja o levantamento das alterações líquidas nas emissões de $\mathrm{CO}_{2}$ dos combustíveis fósseis devido à atividade do projeto incluindo o consumo desses combustíveis na própria área de extensão definida e, as alterações na linha de base das emissões de $\mathrm{CO}_{2}$ relativas aos despachos que ocorrem no segmento de geração de energia elétrica, dentro do sistema interligado, a partir de plantas onde o combustível fóssil é utilizado (EXECUTIVE BOARD, 2004).

Não se faz necessário a contabilização do potencial de emissão de metano resultante do armazenamento de bagaço, pois se considera que essas emissões são desprezíveis quando o mesmo for armazenado em pilhas (onde há circulação de ar) por menos de um ano e das emissões de dióxido de carbono que ocorrem no seu transporte. Outras emissões decorrentes da combustão do combustível, também não serão consideradas tais como: metano e os óxidos de nitrogênio (EXECUTIVE BOARD, 2004).

\section{SISTEMAS ELÉTRICOS}

A seguir, serão apresentadas algumas delimitações dos sistemas elétricos de forma a auxiliar a determinar os fatores de emissão e os intercâmbios entre esses sistemas. 


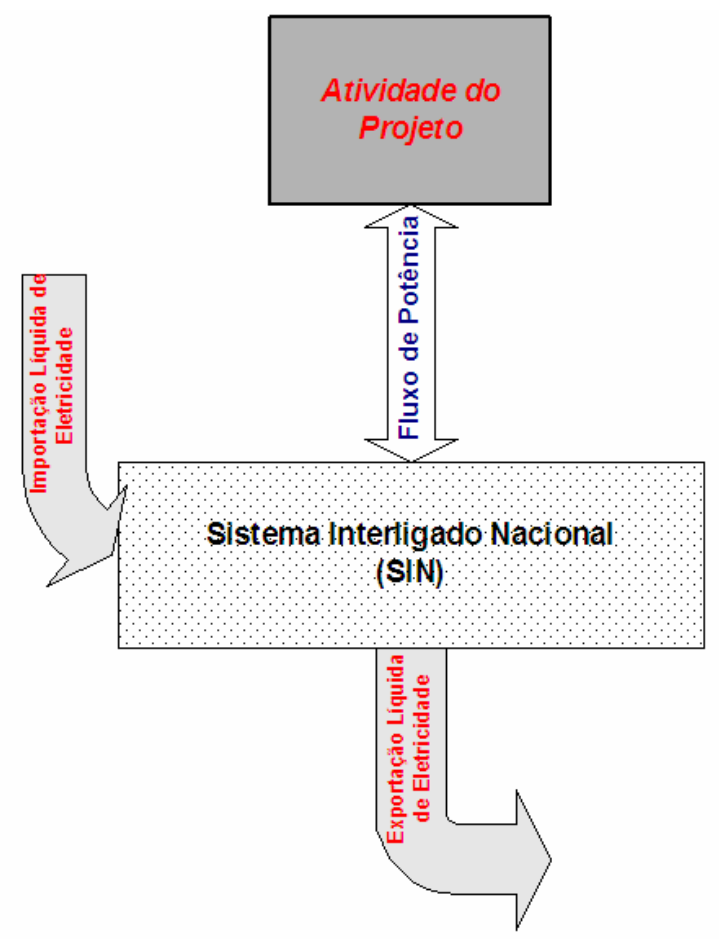

Figura 3.4. Limites do Projeto - Delimitação dos sistemas envolvidos sob o aspecto da geração de eletricidade.

A metodologia permite que para a determinação dos fatores de emissão, a consideração se a energia deslocada é de todo o sistema interligado nacional ou da regionalização de um sistema interligado. Para o caso de Estado de São Paulo, o ONS distingue esta região como subsistema, Centro-Oeste/Sudeste/Sul.

\section{SISTEMA ELÉTRICO DO PROJETO}

É todo o sistema de eletricidade definido dentro das dimensões espaciais do projeto onde a energia elétrica a ser despachada não possui restrições significantes na transmissão.

\section{SISTEMA ELÉTRICO INTERLIGADO}

É o sistema elétrico interconectado seja na dimensão nacional ou internacional onde as plantas de geração de eletricidade podem despachar sem restrições significantes de fluxo de potências.

\section{INTERCAMMBIO ENTRE SISTEMAS}

São considerados dois casos, como pode ser visto a seguir: 
i. Importação de eletricidade - A transferência de potência partindo do sistema conectado para o definido no projeto; e,

ii. Exportação de eletricidade: O intercâmbio contrário ao definido em (i), o sistema definido pelo projeto transfere potência para o sistema interligado;

\section{CENÁRIO DE BASE}

Para a aplicabilidade da metodologia, os itens a seguir devem ser preenchidos:

i. A planta geradora de eletricidade deverá estar conectada ao sistema elétrico interligado;

ii. O projeto deve demonstrar que, a existência tanto de programas quanto de políticas de incentivo não removem as barreiras existentes para a implementação do projeto. E que na ausência dos incentivos do MDL a atividade não seria atrativa seja por competitividade com outras tecnologias ou pela inviabilidade econômica; e,

iii. A implantação do projeto não deve aumentar a produção de bagaço na área definida pelo empreendimento.

Para a seleção adequada do cenário da linha de base, o interessado deverá responder questionamentos relativos à forma de suprimento de eletricidade e calor bem como a destinação da biomassa na ausência do projeto. A metodologia prevê, também, que na presença de cenários semelhantes, deverá se optar pelo cenário mais provável (realístico) entre os dois e o que apresentar a menor emissão na linha de base.

A definição do cenário de base, para este caso em estudo, que utiliza o bagaço como fonte de energia primária para a planta de co-geração deve considerar que a redução na emissão é resultado do deslocamento tanto da energia térmica quanto da elétrica gerada a partir dos combustíveis fósseis.

Em projetos que envolvam melhoramentos de equipamentos e modificações na planta de geração de eletricidade, as linhas de base deverão fazer referência às características de emissões atuais da planta desde que as modificações não alterem a produção e a vida útil do sistema considerado no projeto. Em casos onde há alterações desse tipo, uma nova 
metodologia deve ser aplicada para as condições específicas que as mudanças introduzam (EB08-Anexo1, 2003).

As opções disponíveis para composição do cenário estão calcadas sob a ótica da geração de energia elétrica, térmica e da biomassa a ser utilizada. Para este trabalho, foram selecionadas as seguintes opções ${ }^{23}$ :

- Planta industrial existente e que já queima a biomassa. No entanto, há baixa eficiência na geração do excedente de eletricidade;

- Planta industrial existente e que já queima a biomassa. No entanto, há baixa eficiência na geração de calor; e,

- O resíduo da biomassa já é utilizado para geração de eletricidade e calor na área da atividade.

A metodologia possui uma tabela (ACM0006, 2006 - Tabela 01 p.7) que correlaciona todas as opções (energia elétrica, térmica, uso do combustível) para composição do cenário. Com as premissas apresentadas acima, chegou-se ao cenário de número 04 (numeração da metodologia).

Para este cenário de base, as emissões desconsideradas para geração de eletricidade proveniente do SIN e o calor utilizado na planta são os gases metano e óxido nitroso, considerando-se apenas o gás carbônico. O metano é apenas considerado no cenário de base se houver manuseio de excedente de biomassa e neste caso é o responsável pelo projeto que decide a sua inclusão ou não.

Já na área prevista para a atividade, o gás considerado no transporte da biomassa é apenas o $\mathrm{CO}_{2}$ e na etapa de estocagem não se considera a existência de emissões. Já na etapa de queima da biomassa para geração de eletricidade/calor, o $\mathrm{CO}_{2}$ novamente é considerado e o metano pode ou não ser contabilizado dependendo da sua consideração ou não no cenário de base.

Após a validade da emissão dos créditos relacionados à atividade do projeto, todos os parâmetros deverão ser recalculados para a determinação da margem combinada.

\section{REDUÇÃO NAS EMISSÕES - LINHA DE BASE}

\footnotetext{
${ }^{23}$ Baseou-se num cenário representativo do setor no Estado de São Paulo, onde o principal potencial é a melhora da eficiência energética nas usinas existentes.
} 
Os dados utilizados deverão ser medidos se possível ou extraídos de fontes da região ou do país desde que confiáveis. Caso contrário, recomenda-se a utilização dos fatores e coeficientes de emissão bem como os valores caloríficos constantes no IPCC Good Practice Guidance 2000 .

A figura a seguir, apresenta como se distribuem os fatores de emissão discutidos nesta seção e apresentados com maiores detalhes no Anexo B.

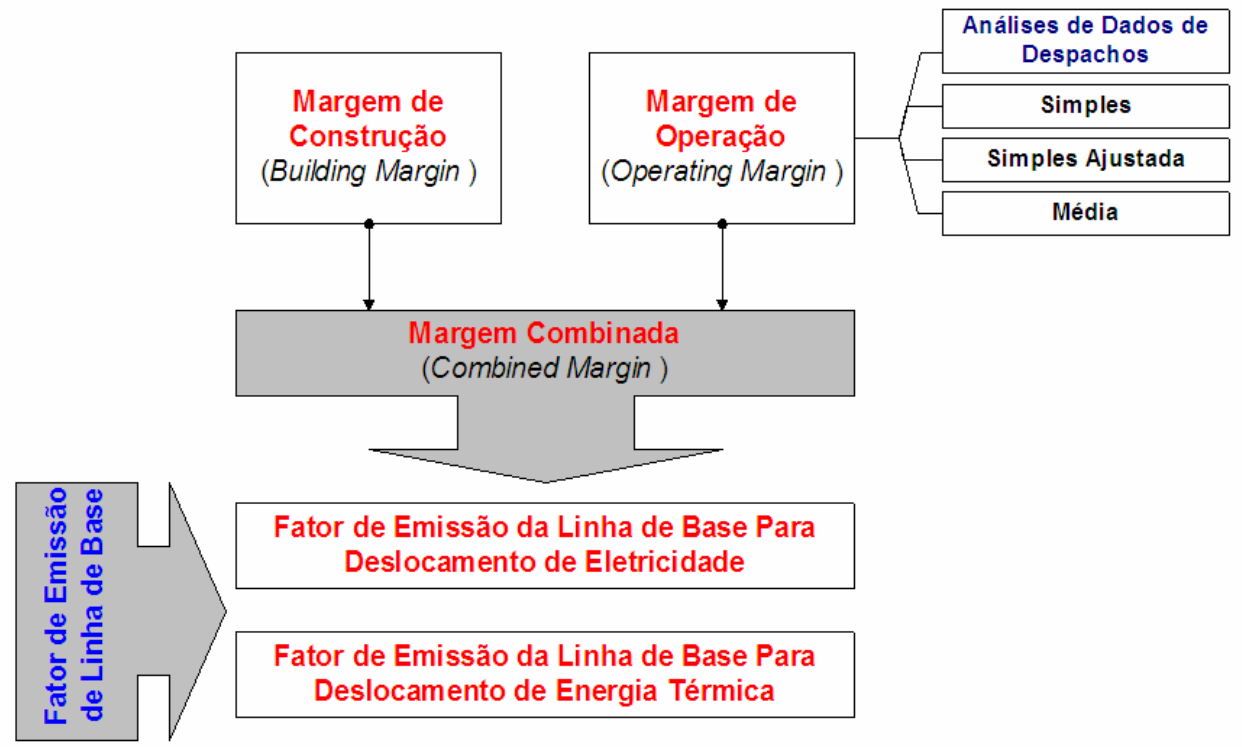

Figura 3.5. Diagrama esquemático das formas de quantificação dos fatores de emissão envolvidos na avaliação do cenário de linha de base.

\section{DESLOCAMENTO DA ELETRICIDADE}

Para a consideração da redução nas emissões provenientes do deslocamento de eletricidade, deve-se considerar: o produto entre a eletricidade gerada pelo projeto com o fator de emissão do sistema interligado na ausência da energia gerada pelo projeto proposto. Isto é, pelo fator de emissão de linha base para o caso de deslocamento de energia elétrica.

$\mathrm{RE}_{\text {eletricidade, ano }}=$ Energia Gerada $_{\text {ano }} \cdot$ Fator de Emissão ${ }_{\text {ano }} \mathrm{tCO}_{2 \mathrm{eq}} /$ ano 1

Para o Cenário 04, o fator de emissão da atividade desloca a eletricidade gerada de outras fontes de energia conectadas ao SIN ou de plantas que queimam biomassa de forma menos eficiente. Neste caso, o Fator de Emissão ${ }_{\text {ano }}=$ Fator de Emissão do SIN $_{\text {ano }}$ sendo determinado da seguinte forma: 
- Se a potência for superior a $15 \mathrm{MW}$ o fator de emissão deverá ser calculado como margem combinada (MC) conforme estabelecido em "Consolidated baseline methodology for grid-connected electricity generation from renewable sources" (ACM0002) e apresentado em maiores detalhes no Anexo B; ou,

- Se a potência for inferior a $15 \mathrm{MW}$ utilizar um fator médio de emissão que considere todas as plantas conectadas ao SIN em operação, conforme apresentado em "Consolidated baseline methodology for grid-connected electricity generation from renewable sources" (ACM0002) e apresentado em maiores detalhes no Anexo B;

\section{DESLOCAMENTO DE ENERGIA TÉRMICA}

Se o calor adicional gerado seja por um uso mais intensivo do resíduo da biomassa ou pela melhora no sistema de geração de calor e estes não apresentarem emissões adicionais considerando um mesmo combustível, então este fator pode ser considerado nulo. No entanto, caso haja co-queima com combustíveis fósseis ou utilização dos mesmos para dar partida nas caldeiras, as emissões deverão ser consideradas.

Para o Cenário 04, a seguinte equação é proposta na necessidade de estimar a redução nas emissões:

$\mathrm{RE}_{\text {calor, ano }}=\left(\mathrm{Q}_{\text {projeto }} * \mathrm{COEF}_{\mathrm{i}}\right) /\left(\varepsilon_{\text {caldeira }} * \mathrm{NCV}_{\mathrm{i}}\right) * 1-\left(\varepsilon_{\text {atual da planta }} / \varepsilon_{\text {projetado }}\right) \mathrm{tCO}_{2 \mathrm{eq}} /$ ano 2

Onde $\left(\mathrm{Q}_{\text {projeto }}\right)$ é o calor líquido gerado pela planta de cogeração; $\left(\mathrm{COEF}_{\mathrm{i}}\right.$ e $\left.\mathrm{NCV}_{\mathrm{i}}\right)$ são os fatores de emissão e poder calorífico do combustível fóssil a ser deslocado; ( $\left.\varepsilon_{\text {caldeira }}\right)$ é a eficiência da caldeira; $\left(\varepsilon_{\text {atual da planta }}\right.$ e $\left.\varepsilon_{\text {projetado }}\right)$ são as eficiências médias da planta para geração de calor, antes e depois da implementação do projeto.

\section{EMISSÕES DA ATIVIDADE DO PROJETO}

As emissões provenientes da combustão de qualquer combustível fóssil dentro do projeto devem ser contabilizadas. Principalmente, as emissões devidas ao transporte de biomassa, ao consumo de combustíveis fósseis e, se for considerado, as emissões de metano provenientes da queima da biomassa.

$\mathrm{EP}_{\mathrm{ano}}=\mathrm{E}_{\text {Transporte, ano }}+\mathrm{E}_{\text {Consumo Combustíveis Fósseis, ano }}+\mathrm{GWP}_{\mathrm{CH} 4} * \mathrm{E}_{\text {Queima da Biomassa } \mathrm{CH} 4 \text {, ano }}$ $\mathrm{tCO}_{2 \text { eq }} /$ ano 3 
Se a biomassa for queimada de uma forma descontrolada ou sofrer alterações por estar exposta em excesso ao meio, as emissões deverão ser consideradas. Sendo considerado para ambos os casos o valor de emissão encontrado para a queima descontrolada. Normalmente, este fator é considerado nulo na ausência destes fatos e é desta premissa que o Cenário 04 parte.

$\mathrm{E}_{\text {Biomassa, ano }}=0 \mathrm{tCO}_{2 \mathrm{eq}} / \mathrm{ano} 4$

\section{FUGA}

Fuga ou leakage é o deslocamento de emissão que pode ocorrer fora dos limites do projeto e que é mensurável e atribuível à atividade do projeto em questão. O raio mínimo de análise definido pela metodologia é de $20 \mathrm{Km}$ até no máximo $200 \mathrm{Km}$.

No cálculo desse fator de emissão, deve-se considerar qualquer aumento no consumo de combustíveis fósseis fora dos limites da extensão do projeto devida à implementação do mesmo. Isto é, qualquer indisponibilidade de bagaço fora dos limites do projeto e que possa resultar em utilização de combustíveis fósseis no local onde o bagaço era originalmente utilizado.

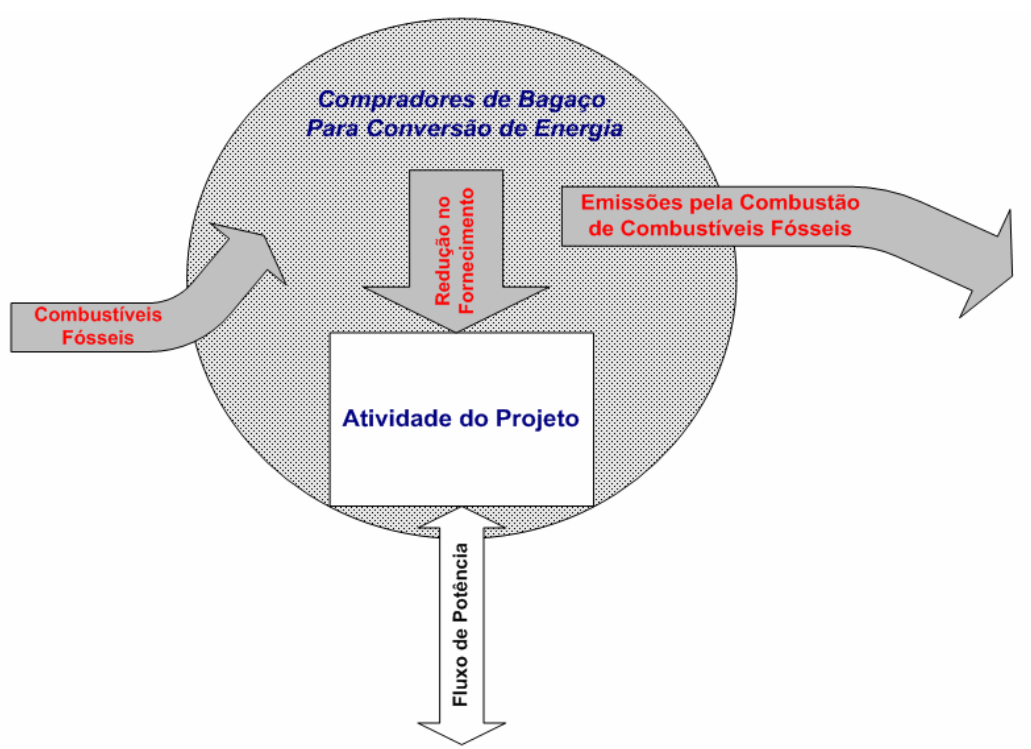

Figura 3.6. Exemplo de fuga com base na indisponibilidade no mercado local de bagaço devida à atividade. 


\section{TOTAL DA REDUÇÃO NAS EMISSÕES}

É a redução líquida total como resultado da atividade do projeto durante um ano como:

$\mathrm{RE}_{\text {ano }}=\mathrm{RE}_{\text {calor, ano }}+\mathrm{RE}_{\text {eletricidade, ano }}+\mathrm{E}_{\text {Biomassa, ano }}-\mathrm{EP}_{\text {ano }}-\mathrm{F}_{\text {ano }} \mathrm{tCO}_{2 \mathrm{eq}} /$ ano 5

Onde:

$\mathrm{RE}_{\mathrm{ano}} \quad$ redução nas emissões devido a operação do projeto no ano em $\mathrm{tCO}_{2 \mathrm{eq}}$;

$\mathrm{RE}_{\text {eletricidade, ano }}$ redução nas emissões devido ao deslocamento de eletricidade durante o ano em $\mathrm{tCO}_{2 \mathrm{eq}}$;

$\mathrm{RE}_{\text {calor, ano }}$ redução nas emissões devido ao deslocamento de calor durante o ano em $\mathrm{tCO}_{2 \mathrm{eq}}$

E Biomassa, ano emissões da linha de base devido ao decaimento natural da biomassa ou queima descontrolada no ano em $\mathrm{tCO}_{2 \mathrm{eq}}$;

$\mathrm{EP}_{\mathrm{ano}}$ são as emissões relativas à atividade do projeto durante o ano em $\mathrm{tCO}_{2 \mathrm{eq}}$; e, $\mathrm{F}_{\mathrm{ano}} \quad$ são as emissões relativas ao efeito de fuga durante o ano em $\mathrm{tCO}_{2 \mathrm{eq}}$.

\subsubsection{METODOLOGIA - VINHAÇA}

\section{APLICABILIDADE}

Esta metodologia foi desenvolvida e aplicada inicialmente para um sistema de tratamento que aberto e apropriado para as condições anaeróbias, caracterizados da seguinte forma:

- Profundidade da lagoa de, pelo menos, $1 \mathrm{~m}$;

- Temperatura acima de $10^{\circ} \mathrm{C}$. Se a temperatura média de um determinado mês for inferior a este valor, ele não pode ser incluído nas estimativas sendo assumido que não há atividade anaeróbia abaixo desta temperatura; e,

- O tempo de retenção da matéria orgânica deve ser de no mínimo, 30 dias.

\section{A ATIVIDADE DE PROJETO}


O objetivo deste tipo de projeto é evitar a emissão de metano advinda de lagoas abertas através da combinação ou até mesmo de uma das seguintes opções de tratamento do material orgânico:

- Instalação de digestor anaeróbio com extração de biogás que pode ser queimado num flare ou utilizado para gerar eletricidade e/ou calor.

Nesta configuração, contabilizar apenas a quantidade de emissão de metano evitada para estabelecer a linha de base não é adequado, pois a atividade irá extrair mais metano do que seria emitido na linha base (devido à mudança de processo, isto é, uma taxa superior à normal para extração de metano).

\section{OS LIMITES DO PROJETO}

Os limites do projeto estão definidos como os limites da planta que gera o resíduo a ser tratado nas condições anaeróbias. As seguintes fontes de emissão são consideradas:

- Linha de Base:

○ Emissões provenientes do processo de tratamento: $\mathrm{O}$ gás metano é a maior fonte do cenário, sendo desprezado $\mathrm{o} \mathrm{CO}_{2}$ proveniente da decomposição orgânica e o $\mathrm{NO}_{2}$ foi excluído por simplificação metodológica;

○ Emissões provenientes da geração/consumo de eletricidade: $O$ dióxido de carbono foi considerado como principal componente em ambos os casos de consumo ou geração de eletricidade. Os gases $\mathrm{NO}_{2}$ e $\mathrm{CH}_{4}$ foram excluídos para simplificação sendo assumido que são hipóteses conservativas; e,

○ Emissões provenientes da geração de energia térmica: premissa idêntica ao item anterior.

- Projeto:

- Consumo no local de combustíveis fósseis: O dióxido de carbono foi considerado como principal componente. Os gases $\mathrm{NO}_{2}$ e $\mathrm{CH}_{4}$ foram excluídos para simplificação sendo assumido que a fonte de emissão para este caso é muito pequena; 
- Emissões pelo uso no local de eletricidade: O dióxido de carbono foi considerado como principal componente, com a ressalva de que se a eletricidade for proveniente do biogás extraído, estas emissões não serão contabilizadas. Os gases $\mathrm{NO}_{2}$ e $\mathrm{CH}_{4}$ foram excluídos para simplificação sendo assumido que a fonte de emissão para este caso muito pequena; e,

- Emissões diretas do processo de tratamento do resíduo: O gás metano é a maior fonte do cenário por fuga (perdas durante o processo de tratamento) ou emissão de gás sem combustão, sendo desprezado o $\mathrm{CO}_{2}$ proveniente da decomposição orgânica e o $\mathrm{NO}_{2}$ por não ser considerado importante para esta situação.

Na fase de definição do cenário de linha de base, os seguintes passos são apresentados:

a) Apresentar uma lista de alternativas viáveis para tratamento do resíduo;

b) Eliminar alternativas que não atendam a legislação e resoluções locais;

c) Eliminar alternativas que possuam barreiras proibitivas (que não atendam o critério de adicionalidade); e,

d) Comparar a atratividade econômica entre as alternativas remanescentes.

A análise do investimento é válida para definir o cenário de linha de base como sendo o que apresente o melhor custo-benefício. Se, esta análise ainda não for completamente conclusiva, uma análise de sensibilidade entre as opções existentes servirá para subsidiar a opção.

\section{CENÁRIO DE BASE}

A área física que delimita o projeto é a área da própria planta. As emissões provenientes do projeto basicamente consistem nas emissões das lagoas, fugas (perdas) dos sistemas digestores e das emissões dos equipamentos de flare e geração bem como das outras fases do processo.

\section{REDUÇÃO NAS EMISSÕES - LINHA DE BASE}

As emissões para a linha de base são as emissões de metano provenientes da área da lagoa, o dióxido de carbono associado com o deslocamento de energia elétrica do sistema interligado 
e, também, das emissões evitadas da queima de combustíveis fósseis pelo deslocamento de energia térmica.

\section{EMISSÕES DA ÁREA DA LAGOA}

Estas emissões são estimadas com base na demanda química de oxigênio (COD) do efluente que entra na lagoa na ausência do projeto, na capacidade máxima de produção de metano $\left(\mathrm{B}_{\mathrm{o}}\right)^{24}$ e no fator de conversão de metano (MCF) que representa a porção de efluente que é anaerobiamente tratado da lagoa. Sendo assim, as emissões de metano são contabilizadas da seguinte forma, em fatores consolidados mensalmente ${ }^{25}$ :

Emissões. $\mathrm{CH}_{4}=C O D * B_{o} * M C F \quad \mathrm{~kg} \mathrm{CH}_{4} /$ mês

Sendo que o MCF é estimado como produto da fração da degradação anaeróbia pela profundidade da lagoa $\left(\mathrm{f}_{\mathrm{d}}\right)$ que varia de $70 \%, 50 \%$ e $0 \%$ em profundidades maiores que $5 \mathrm{~m}$, entre 5 e $1 \mathrm{~m}$ e menores que $1 \mathrm{~m}$, e pela fração de degradação anaeróbia pela temperatura $\left(\mathrm{f}_{\mathrm{t}}\right)$. Ambos os fatores são multiplicados por 0,89 que é um fator empregado para tornar o valor conservativo, pois se considera degradação anaeróbia total quando se atinge uma temperatura de $30{ }^{\circ} \mathrm{C}$. O equacionamento fica da seguinte forma:

$M C F=f_{d} * f t * 0,89$ Adimensional

E o fator de degradação anaeróbia pela temperatura é calculado da seguinte forma:

$f t=e^{\frac{E \cdot\left(T_{2}-T_{1}\right)}{R \cdot T_{1} \cdot T_{2}}}$, onde E é a energia de ativação considerada constante $(15,175 \mathrm{cal} / \mathrm{mol}), \mathrm{R}$ a constante ideal dos gases, $T_{2}$ a temperatura ambiente e $T_{1}$ a temperatura onde a degradação é considerada máxima $\left(30^{\circ} \mathrm{C}\right)$.

O total de emissões de metano para a linha de base é convertido em dióxido de carbono equivalente multiplicando o valor encontrado pelo seu GWP, isto é, por 21.

a) Cenário de emissões do deslocamento de eletricidade e energia térmica é dado por:

$$
\text { Emissões }_{\text {eletricidadel térmica }}=E G_{c} * E G_{b} * E G_{t} * C E F_{\text {eletricidade }} * C E F_{\text {rede }} * C E F_{\text {térmico }} \mathrm{kg} \mathrm{CO}_{2 \mathrm{eq}} / \mathrm{ano}
$$

\footnotetext{
${ }^{24}$ A metodologia recomenda utilizar um valor de $0,21 \mathrm{~kg} \mathrm{CH} 4$ / $\mathrm{kg}$ COD que é o menor valor apresentado pelo IPCC Good Practive Guidance, 2000, Fl. 5.19 considerado como um valor conservativo para Bo.

${ }^{25}$ No entanto, os cálculos são agrupados por intervalos de um ano.
} 
$\mathrm{EG}_{\mathrm{c}}$ é a eletricidade consumida pela planta na ausência do projeto, $\mathrm{EG}_{\mathrm{b}}$ é a eletricidade gerada com a utilização do biogás e exportada para o sistema interligado, $\mathrm{EG}_{\mathrm{t}}$ energia térmica que foi

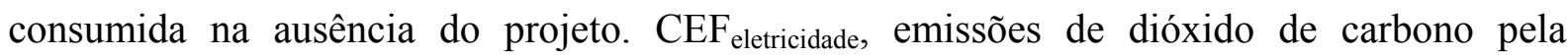
eletricidade consumida na ausência do projeto, $\mathrm{CEF}_{\text {rede }}$ é o fator de emissão de dióxido de carbono do sistema interligado onde a eletricidade é exportada, $\mathrm{CEF}_{\text {térmico }}$ são as emissões de dióxido de carbono correspondente a energia térmica proveniente da queima de combustíveis fósseis.

\section{EMISSÕES DE METANO NA LAGOA}

Emissões. $\mathrm{CH}_{4}=C O D * B_{o} * M C F \quad \mathrm{~kg} \mathrm{CH}_{4} /$ ano

Esta equação já foi vista anteriormente, mas a grande diferença está no emprego do MCF, pois se o sistema de digestão tratasse 100 \% do material orgânico, o MCF é zero.

\section{PERDA NO SISTEMA DE BIODIGESTORES}

A perda física do sistema é estabelecida pelo IPCC como sendo $15 \%$ do total de biogás produzido. Caso o empreendedor estime um número inferior, ele deverá apresentar medições que comprovem o novo número apresentado.

\section{QUEIMA NO SISTEMA DE FLARE E GERAÇÃO}

O metano pode ser liberado como resultado da combustão incompleta tanto no flare quanto no sistema de geração de energia elétrica e/ou térmica. Estas emissões serão estimadas com a utilização de um sistema de monitoramento.

\section{DESLOCAMENTO DE ELETRICIDADE E CALOR}

Esta quantificação só é válida se há consumo externo tanto de eletricidade quanto de calor pelo sistema proposto pelo projeto. Caso ambos sejam fornecidos pelo uso do biogás, neste caso as emissões serão nulas. O equacionamento, caso haja fornecimento externo é dado por:

$$
\text { Emissões }=E_{\text {elétrica }} * C E F_{\text {eletricidade }}+E_{\text {térnica }} * C E F_{\text {térmica }} \mathrm{kg} \mathrm{CO}_{2 \mathrm{eq}} / \text { ano }
$$

Onde a $E_{\text {elétrica }}$ e $E_{\text {térmica }}$ são as energias consumidas pela planta do projeto e os $C_{E F}$ eletricidade $\mathrm{e}$ $\mathrm{CEF}_{\text {térmica }}$ são os fatores de emissão estimados. 
Emissões. $\mathrm{CH}_{4}=C O D * B_{o} * M C F \quad \mathrm{~kg} \mathrm{CH}_{4} /$ ano

Neste caso, o COD se refere ao efluente após o tratamento e o MCF considerado pela metodologia é de 0,05 .

Emissões. $\mathrm{N}_{2} \mathrm{O}=\mathrm{NC} * \mathrm{~S}_{a} * E F_{\mathrm{N} 2 \mathrm{O}}$

$\mathrm{NC}$ é o conteúdo de nitrogênio no efluente dado em $\mathrm{kg} \mathrm{N} / \mathrm{kg}$ efluente, $\mathrm{S}_{\mathrm{a}}$ é a quantidade de efluente aplicado na terra em kg por ano e $\mathrm{EF}_{\mathrm{N} 2 \mathrm{O}}$ é o fator de emissão do nitrogênio quando o efluente é aplicado na terra, sendo estimado pela presente metodologia em $0,016 \mathrm{~kg} \mathrm{~N}_{2} \mathrm{O} / \mathrm{kg}$ $\mathrm{N}$.

\section{FUGAS}

Fugas não são consideradas no escopo deste tipo de projeto.

\section{TOTAL DA REDUÇÃO NAS EMISSÕES}

De forma sucinta, as reduções nas emissões é a diferença entre o valor encontrado para a linha de base com as emissões do projeto, levando em consideração ajustes necessários das perdas/fugas.

Emissões $_{\text {Linha de Base }}=$ L. B. Lagoa + L.B. Eletricidade + L.B. Energia Térmica

\section{Reduções nas Emissões = Emissões de Linha de Base - Fuga - Emissões de Projeto}

É importante salientar que alguns fatores desta equação só são avalizados num momento posterior e por isso a metodologia de monitoramento passa a ser fundamental para a aquisição das informações durante a operação visando confirmar as premissas utilizadas nas estimativas do projeto, tais como as emissões de metano devido à combustão incompleta no flare ou sistema de geração.

\subsubsection{RESULTADOS ENCONTRADOS}

COGERAÇÃO COM BAGAÇO DE CANA-DE-AÇÚCAR 
São características comuns aos 23 projetos de concepção MDL disponíveis através do website do Ministério de Ciências e Tecnologia que utilizam o bagaço para fins energéticos:

- Aumento da eficiência da unidade de cogeração. Isto é, aumentar a eficiência do vapor na produção de açúcar e/ou álcool e aumentar a eficiência da queima do bagaço (caldeiras mais eficientes). Seja por substituição de equipamentos antigos por novos ou inclusão de novos;

- Vapor excedente é usado exclusivamente para produção de eletricidade;

- Ciclo Rankine ${ }^{26}$;

- Ausência de financiamento público ${ }^{27}$;

- Período de quantificação de créditos fixado em 7 anos;

- Para Usinas conectadas ao bloco S/SE/CO:

- Fator de Emissão de Operação na Margem 2002 a $2004^{28}=0,431$ tCO $_{2 \mathrm{eq}} / \mathrm{MWh}$

- Fator de Emissão de Construção na Margem $2004=0,1045$ tCO $_{2 \mathrm{eq}} / \mathrm{MWh}$

- Fator de Emissão de Eletricidade ${ }^{29}=0,5 * 0,4310+0,5 * 0,1045=0,2677$ $\mathrm{tCO}_{2 \mathrm{eq}} / \mathrm{MWh}$

- Para Usinas conectadas ao bloco N/NE:

- Fator de Emissão de Operação na Margem 2001 a $2003^{30}=0,1178$ tCO 2 eq $/ \mathrm{MWh}$

- Fator de Emissão de Construção na Margem $2003=0,0311 \mathrm{tCO}_{2 \mathrm{eq}} / \mathrm{MWh}$

- Fator de Emissão de Eletricidade ${ }^{31}=0,5 * 0,1178+0,5 * 0,0311=0,0745$ $\mathrm{tCO}_{2 \mathrm{eq}} / \mathrm{MWh}$

\footnotetext{
${ }^{26}$ Maiores informações sobre este ciclo no Anexo A.

${ }^{27}$ Exceção Projeto de Cogeração da Usina Vale do Rosário.

${ }^{28}$ Fator de Emissão de Operação na Margem, ver maiores informações no Anexo B.

${ }^{29}$ Fator de Ponderação $(\omega)$ igual à $50 \%$ em ambos os casos.

${ }^{30}$ Fator de Emissão de Operação na Margem, ver maiores informações no Anexo B.

${ }^{31}$ Fator de Ponderação $(\omega)$ igual à $50 \%$ em ambos os casos.
} 
Tabela 3.1. Resumo dos principais resultados dos Estudos de Caso MDL. Fonte: PDDs de cada projeto citado

Legenda: (*) Cálculo indireto / C - CPFL / E - Enertrade / CE - CEMAT /E - ELEKTRO / EPELETROPAULO / AL -CEAL /MG-CEMIG.

\begin{tabular}{|c|c|c|c|c|}
\hline Projeto & $\begin{array}{c}\text { Redução } \\
\text { Emissões } \\
\text { tCO } \\
\text { anoq }-7 \\
\end{array}$ & $\begin{array}{c}\text { Potência } \\
\text { Instalada } \\
\text { MW }\end{array}$ & $\begin{array}{c}\text { Energia } \\
\text { Comercializáv } \\
\text { el GWh/ano }\end{array}$ & $\begin{array}{l}\text { Contrato de } \\
\text { Venda de } \\
\text { Energia } \\
\text { (PPA) } \\
\end{array}$ \\
\hline $\begin{array}{l}\text { Cogeração com Bagaço Cruz Alta } \\
\text { (PCBCA) }\end{array}$ & $70.427,00$ & 29,80 & 40,00 & C \\
\hline Cogeração com Bagaço Lucélia (PCBL) & $100.534,00$ & 44,63 & 103,86 & EN \\
\hline Cogeração Santa Terezinha - Tapejara & $264.553,00$ & $\begin{array}{l}\text { Não } \\
\text { Informado }\end{array}$ & 142,00 & $\begin{array}{l}\text { Não } \\
\text { Informado }\end{array}$ \\
\hline Cogeração com Bagaço Nova América & $78.303,00$ & $\begin{array}{c}\text { Não } \\
\text { Informado }\end{array}$ & 41,80 & $\begin{array}{l}\text { Não } \\
\text { Informado }\end{array}$ \\
\hline $\begin{array}{l}\text { Cogeração com Bagaço Jalles Machado } \\
\text { (PCBJM) }\end{array}$ & $72.056,00$ & $28,00^{*}$ & 38,50 & C \\
\hline $\begin{array}{l}\text { Projeto de Cogeração com Bagaço } \\
\text { Colombo (PCBC) }\end{array}$ & $196.128,00$ & 103,00 & 158,00 & C \\
\hline $\begin{array}{l}\text { Cogeração com Bagaço Usinas Caeté } \\
\text { Sudeste }\end{array}$ & $212.280,00$ & 85,00 & 181,00 & MG \\
\hline Cogeração com Bagaço Coinbra & $127.209,00$ & $36,60^{*}$ & 67,90 & $\mathrm{C} / \mathrm{E}$ \\
\hline Cogeração com Bagaço Campo Florido & $71.227,00$ & 24,00 & 44,00 & MG \\
\hline Cogeração com Bagaço Serra (PCBS) & $46.509,00$ & 15,00 & 29,35 & C \\
\hline Cogeração com Bagaço Coruripe (PCBC) & $40.488,00$ & 32,00 & 77,63 & AL \\
\hline $\begin{array}{l}\text { Cogeração com Bagaço Zillo Lorenzetti } \\
(Z L B C P)\end{array}$ & $390.218,00$ & $87,71^{*}$ & 208,30 & C \\
\hline $\begin{array}{l}\text { Cogeração Central Energética Rio Pardo } \\
(C E R P A)\end{array}$ & $118.546,00$ & $40,00^{*}$ & 63,20 & $\mathrm{C}$ \\
\hline $\begin{array}{l}\text { Cogeração com Bagaço Alta Mogiana } \\
(P C B A M)\end{array}$ & $84.165,00$ & 37,50 & 49,00 & C \\
\hline $\begin{array}{l}\text { Cogeração com Bagaço Cerradinho } \\
(P C B C)\end{array}$ & $243.194,00$ & 65,00 & 215,00 & $\mathrm{C} / \mathrm{EP}$ \\
\hline Cogeração com Bagaço Equipav & $222.748,00$ & 60,50 & 130,00 & $\mathrm{C} / \mathrm{EP}$ \\
\hline Cogeração com Bagaço Moema (PCBM) & $91.976,00$ & 24,00 & 40,00 & $E$ \\
\hline Termoelétrica Santa Adélia (TSACP) & $161.583,00$ & $42,00^{*}$ & 86,30 & $\mathrm{C}$ \\
\hline $\begin{array}{l}\text { Cogeração com Bagaço Alto Alegre } \\
(P C B A A)\end{array}$ & $67.718,00$ & 37,20 & 40,00 & CE \\
\hline Bioenergia Cogeradora S.A. & $151.655,00$ & 36,00 & 78,00 & $\mathrm{C}$ \\
\hline $\begin{array}{l}\text { Cogeração com Bagaço Vale do Rosário } \\
(P C B V R)\end{array}$ & $176.937,00$ & 65,00 & 118,00 & C \\
\hline $\begin{array}{l}\text { Cogeração com Bagaço Santa Elisa } \\
\text { (PCBSE) }\end{array}$ & $320.604,00$ & 73,00 & 216,00 & C \\
\hline $\begin{array}{l}\text { Cogeração com Bagaço Santa Cândida } \\
\text { (PCBSC) }\end{array}$ & $74.225,00$ & 29,00 & 52,00 & C \\
\hline Total & $3.383 .283,00$ & 994,94 & $2.219,84$ & \\
\hline
\end{tabular}


Destaca-se o projeto de cogeração com bagaço Jalles Machado (PCBJM) que prevê além do aumento da capacidade de cogeração do bagaço e melhoria da eficiência energética da usina de açúcar, a substituição do sistema de irrigação com bombas a diesel por bombas de irrigação elétricas.

O valor da potência instalada total encontra-se consistente, apesar de ser superior, em comparação à potência apresentada no item 3.1., pois aqui se trata de potência instalada autorizada pela ANEEL e os valores apresentados nos documentos dos projetos são os valores efetivos por etapas de implementação.

Considerando as informações apresentadas nos PDDs, as empresas que contrataram a eletricidade gerada e fornecida à rede dos projetos acima listados, deste universo, a CPFL assinou contrato com 65,22 \% dos projetos, seguido da CEMIG, ELETROPAULO e ELEKTRO com 8,7 \% cada e pela ENERTRADE e CEAL com 4,35 \% cada. Dos empreendimentos listados na tabela 3.1. apenas 04 deles, isto é $17,4 \%$, tinham contratos PPAs assinados com a ELETROBRÁS via PROINFA, mas a potência apresentada na tabela supracitada em nada está relacionada com o montante deste Programa.

$\mathrm{Na}$ verdade, o incremento na potência instalada (expansão) que resultou no desenvolvimento destes projetos MDL é resultado da decisão das companhias em assinar um PPA de longo prazo com os distribuidores de eletricidade. O que representa os riscos que estas usinas estão dispostas a assumir, parcialmente, devido ao retorno esperado do MDL, pois além da energia se encontrar negociada via contratos de venda com as distribuidoras, do retorno via negociação dos certificados de redução de emissão há também a possibilidade da venda de excedentes diretamente no mercado spot, onde a contratação de energia é dita livre (ACL) ou até mesmo via leilão de energia. A venda no ACL pode vir a ser atrativa se levada em conta a série histórica de 2004 a 2006 (CCEE, 2007) onde o período de safra conteve os maiores preços médios por MWh para os submercados S/SE/CO. Contudo, estes valores não superam os oferecidos pelo VE do PROINFA ou do VR para geração distribuída, mas esta situação pode vir a se alterar caso ocorra a postergação na entrada de novos empreendimentos no médio/longo prazos ou grandes variações nos regimes pluviométricos.

Segundo a CPFL (2005), o valor de referência (VR) para contratação via PPA é de 77,00 R\$/MW para os anos de 2005 e 2006 respectivamente. Este valor foi calculado com base no máximo valor encontrado no leilão de energia existente realizado em 2004. Cabe ressaltar que 
as distribuidoras estão limitadas a contratar até $10 \%$ da sua carga para serem alimentadas com eletricidade proveniente da geração distribuída. Este $\mathrm{VR}^{32}$ quando comparado aos $\mathrm{VE}^{14}$ da biomassa aplicado no PROINFA, tendo como referência o Estado de São Paulo, é inferior em 7,9 \%. No entanto, se considerarmos que o valor do certificado de redução de emissão varia entre 6,0 - 20,0 U\$/tCO $\mathrm{CO}_{2 \text { eq }}$ para o ano de 2006, este quadro pode se alterar significativamente tornando mais interessantes outras formas de empreender os excedentes de eletricidade além da opção do PROINFA.

\section{VINHAÇA}

O único documento de concepção de projeto MDL que se refere à vinhaça está disponível no site da CDM/UNFCCC é o "Vinasse Anaerobic Treatment Project - Compañía Licorera de Nicaragua, S. A. (CLNSA)" que apresentou a metodologia aprovada pelo Comitê Executivo MDL, AM0013.

Os resultados quantitativos não serão explorados visto que estes são fortemente dependentes das condições de operação da Usina, que utiliza queima de diesel para gerar energia térmica e consumo de energia elétrica vindo do sistema interligado o que gera também dependência da composição da matriz energética da Nicarágua na determinação dos fatores de emissão. Este cenário é bem diferente do cenário do setor sucroalcooleiro no Brasil e em especial do Estado de São Paulo. No entanto, a metodologia foi apresentada, pois a mesma é genérica e credencia o seu uso por qualquer Usina que tenha interesse em explorar este tipo de projeto, sendo uma referência internacional a AM0013.

No entanto, existem alguns aspectos interessantes a serem ressaltados sobre este projeto em específico:

- Planta de cogeração que utiliza 02 biodigestores para tratamento anaeróbio. O metano gerado é capturado e queimado para produzir energia visando deslocar o consumo de eletricidade e óleo diesel na Usina;

- Neste caso, não há excedente de eletricidade para ser exportado ao sistema elétrico interligado;

\footnotetext{
${ }^{32}$ Ambos com referência em 2004, valores não atualizados para o dia de hoje.
} 
- As reduções na emissão estão relacionadas ao metano proveniente da lagoa de armazenamento e do deslocamento de óleo diesel e eletricidade proveniente da queima do mesmo;

- Não é toda a vinhaça que é destinada ao biodigestor, parte vai para o processo de fertirrigação;

- Quanto ao financiamento, o mesmo é composto por:

- instituições financeiras internacionais; e,

- SENTER International (representa várias instituições públicas do governo holandês).

- Taxa interna de retorno do investimento avaliada de 6 a $8 \%$;

- Gera uma energia de 12,0 GWh/ano com consumo interno de 1,0 GWh/ano, estimados.

- $\quad \mathrm{Na}$ implementação do projeto:

- o efluente final dos biodigestores é usado para irrigação e possui um impacto inferior ao meio físico (ambiente) devido a redução da carga orgânica;

- a redução da carga orgânica contida na vinhaça utilizada para fertirrigação neste cenário,

é considerada como um impacto positivo, inclusive sob a ótica da manutenção da qualidade d'água (superfície e/ou subterrânea);

- como impacto negativo é apontado o manuseio e utilização do ácido fosfórico e hidróxido de sódio, como risco laboral;

- o nível ruído é considerado como impacto negativo dentro dos limites da propriedade;

\subsection{CONCLUSÃO}

Com relação ao setor sucroalcooleiro, procurou-se apresentar as metodologias atualmente aprovadas e estabelecidas pelo Comitê Executivo do MDL para estimativa e quantificação das 
reduções de emissões para deslocamentos de energia térmica e elétrica. É interessante notar que, no setor produtivo em questão, novas estratégias podem ser adotadas para um emprego conjunto de ambos os aproveitamentos sob o aspecto da geração de eletricidade e da mitigação de uma externalidade classificada como de impacto global, o efeito estufa.

A utilização da biodigestão, por exemplo, para alimentar o consumo interno de eletricidade bem como auxiliar no consumo de energia térmica da planta pode liberar uma quantidade de eletricidade excedente superior à existente, deslocando uma quantidade maior de energia elétrica no sistema interligado. No entanto, a melhor combinação de ambos os aproveitamento depende de uma análise criteriosa do balanço energético da planta.

Uma demonstração deste potencial é apresentada em Silva e Granato (2002) onde é estimado que a eletricidade gerada através da biodigestão anaeróbia da vinhaça representa cerca de 30 $\%$ da necessidade média de energia elétrica da Usina. Deste modo, um uso conjunto da biomassa da cana (bagaço, palhas e pontas) em conjunto com a vinhaça, pode representar um potencial extra em eletricidade excedente passível de ser comercializados e injetados no SIN, sistemas de subtransmissão ou de distribuição.

Outro benefício, que transcende a questão energética, é o uso de um dos maiores resíduos do processo produtivo da indústria sucroalcooleira que é a vinhaça agregando valor a este resíduo fora a comum utilização controlada do mesmo na fertirrigação.

Segundo o Instituto Euvaldo Lodi - IEL/NC e Serviço Brasileiro de Apoio às Micro e Pequenas Empresas - SEBRAE (2005) em "O novo ciclo da cana - estudo sobre a competitividade do sistema agroindustrial da cana-de-açúcar e prospecção de novos empreendimentos" aponta a utilização energética da vinhaça em duas vertentes:

a) utilização da vinhaça concentrada num ciclo combinado para geração de eletricidade, a vinhaça passa por um conjunto de evaporadores se tornando concentrada e posteriormente utilizada em caldeiras para queima. Como referência, o texto apresenta a experiência cubana neste tipo de aproveitamento. Para uma unidade com capacidade processar 1.200,00 t/ano de vinhaça há um investimento inicial estimado em 480.000,00 US\$, uma taxa interna de retorno de 14,29 \% e um tempo de retorno de 7 anos. Segundo o estudo, os valores estão adequados à realidade cubana, mas quando analisada a realidade brasileira, se prevê uma redução em cerca de 
$30 \%$ do investimento. O nível de complexidade tecnológica considerado pelo estudo para implementação é de médio a baixo; e,

b) digestão anaeróbia da vinhaça consiste no tratamento anaeróbio de vinhaça de caldo misto, em reator de fluxo ascendente com leito de lodo. Os nichos de mercado destacados no estudo do tratamento anaeróbio da vinhaça são: saneamento ambiental e energia, na forma de biogás. Também foi apresentado que a complexidade tecnológica é média e que no Brasil o estágio atual de desenvolvimento é em laboratórios, indicando que a tecnologia necessita de ampliação de escala. Há experiências com plantas de $500 \mathrm{~m}^{3}$ de vinhaça e com reatores para efluentes de cervejarias de até $2.000,0 \mathrm{~m}^{3}$. A estimativa para uma planta piloto para tratar $10 \mathrm{~m}^{3}$ biogás/ $\mathrm{m}^{3}$ vinhaça variam entre 1,0 a 1,5 milhões de US\$.

No tocante à adicionalidade dos projetos que utilizam o bagaço para geração de eletricidade, os relatórios de validação emitidos por entidades certificadoras independentes dentre elas a Det Norske Veritas (DNV) afirmam que a TIR média de grande parte dos projetos supracitados é inferior à taxa SELIC e informam que as receitas da venda de energia não representam mais do que $5 \%$ das receitas principais do negócio, ou seja, a produção de açúcar e álcool, constituindo uma pequena parte da renda total do empreendedor. Tal fato demonstra que o projeto não é suficientemente atrativo em condições comerciais normais e enfrenta, portanto, barreiras para investimentos comprovando a adicionalidade deste tipo de aproveitamento.

Este tipo de informação corrobora a afirmativa apresentada por Souza e Azevedo (2005) de que a geração de excedentes comercializáveis tem sido uma estratégia derivada da necessidade de formação de capacidade preventiva para atender demandas futuras de expansão do core business do setor sucroalcooleiro, podendo tal estratégia significar vantagens competitivas no futuro. Por outro lado, deve-se salientar que também com o sobre investimento, ocorre o aproveitamento de economias de escala, representado pela queda do custo do investimento por MW instalado.

Com relação às metodologias apresentadas neste capítulo e no Anexo B os fatores de emissão para determinação da linha de base no caso em estudo, cogeração utilizando bagaço de cana 
de açúcar, pode ser dividida em dois fatores de emissão, a saber: margens de operação e construção. Ambos podem ser sumarizados na tabela a seguir:

Tabela 3.2. Principais características dos fatores de emissão para determinação do cenário da linha de base.

\begin{tabular}{cc}
\hline Margem de Operação & Margem de Construção \\
\hline $\begin{array}{c}\text { "Emissões existentes } \\
\text { ou históricas" }\end{array}$ & $\begin{array}{c}\text { "Opção de uma ação } \\
\text { atrativa economicamente" }\end{array}$ \\
$\begin{array}{cc}\text { Correlacionada com a } \\
\text { operação }\end{array}$ & $\begin{array}{c}\text { Correlacionada com a } \\
\text { expansão do sistema }\end{array}$ \\
eletroenergética atual & $\begin{array}{c}\text { elétrico. Deslocamentos } \\
\text { e futura das plantas de } \\
\text { temporais ou substituição } \\
\text { de novas plantas } \\
\text { planejadas }\end{array}$ \\
eletricidade no SIN & Planejamento e \\
Operação de curto e & $\begin{array}{c}\text { Planejamento de Longo } \\
\text { médio prazo }\end{array}$ \\
\hline
\end{tabular}

Isto é, a margem de operação possui um caráter de análise mais imediato, procurando refletir a situação do sistema no momento do projeto. Por outro lado, a margem de construção visa avaliar possíveis deslocamentos nos empreendimentos do setor no longo prazo. A distribuição entre as duas margens é feita via um sistema de pesos (ver Anexo B) onde o proponente do projeto avalia qual das duas componentes prepondera ou aceita a recomendação de aplicar pesos iguais aos dois fatores.

Para aproveitamentos eletroenergéticos do setor sucroalcooleiro, ambos os fatores são afetados considerando a complementaridade com a geração hidrelétrica no período de baixo regime pluviométrico o que afeta a operação no curto e médio prazo, mais também no longo prazo quando se considera o mix de eletricidade entre geração térmica e hidrelétrica ${ }^{33}$. Segundo Reis e Pereira (2003), os pequenos projetos de fontes alternativas de energia não serão capazes de deslocar ou postergar a entrada dos grandes empreendimentos em fase de planejamento.

Salienta-se que o PDEE já incorpora a questão das emissões de $\mathrm{CO}_{2 \text { eq }}$ no longo prazo, fornecendo informações e cenários quanto aos patamares de emissão por subsistema $(\mathrm{SE} / \mathrm{CO}$, S, N, NE) do Sistema Interligado Nacional. A inclusão desta informação é muito importante,

\footnotetext{
${ }^{33}$ Salvo os empreendimentos que visam gerar/transmitir grandes blocos de energia, estes não são afetados.
} 
pois auxilia na uniformização dos dados que podem ser utilizados para cálculo da margem de construção e até mesmo na avaliação dos fatores de ponderação. Deverá tornar-se uma referência comum, com certo grau de confiabilidade por ser uma informação apresentada pelo Governo brasileiro com livre acesso e distribuição visto que é documento público. Outra vantagem é que se reduz a margem para discussões e questionamentos pelo Comitê Executivo do MDL na fase de aprovação do projeto, pois é comum que empreendimentos de mesma tipologia (setor sucroalcooleiro) ambos conectados ao mesmo subsistema do SIN apresentarem valores de margem bem distintos o que evidencia a falta de referências confiáveis acerca do assunto.

Outro aspecto importante é a possibilidade de se utilizar subsistemas do SIN, pois como afirma Bosi (2000), países com grandes extensões e com diferentes circunstâncias no seu interior implicam em diferentes redes energéticas, isto é, para definição da linha de base no setor de eletricidade talvez haja a necessidade de se desagregar abaixo do nível nacional para que possa prover representação mais fidedigna tantos dos fatores de emissão quanto dos deslocamentos energéticos correspondentes à interligação de um projeto MDL no subsistema em questão.

Para o caso brasileiro o SIN pode ser dividido em dois grandes blocos: Norte e Nordeste (N/NE) e Sul/Sudeste/Centro-Oeste (S/SE/CO), sendo que ao final de 2004 o reforço entre a interligação destes dois grandes nós foi concluída. Mesmo assim, existe um limite físico de intercâmbio de eletroenergético entre esses dois subsistemas.

Do mesmo modo que a incorporação de informações úteis para a composição da margem de construção dentro do PDEE é vista de modo positivo, a maior crítica é com relação às informações utilizadas para elaboração da margem de operação disponibilizadas somente no período de 2001 a 2004 pelo ONS. Os documentos de concepção de projetos MDL afirmam, em sua maioria que o Operador Nacional do Sistema julga estas informações como estratégicas, evitando ao máximo repassá-las às consultoras considerando que elas podem ser utilizadas por agentes do setor elétrico para outros fins. Fica então a sugestão do ONS apresentar num formato de relatório anual juntamente com os demais dados disponibilizados em domínio público, dados consolidados e sumarizados que possibilitem a utilização dos mesmos para elaboração dos projetos de MDL evitando maiores níveis de detalhamento. 
Outro comentário importante é relativo ao fato do cálculo do fator de emissão não considerar todas as fontes de geração que servem ao sistema, aproximadamente $76,4 \%$ da capacidade instalada que serve ao Brasil está sendo levada em consideração. Os documentos de concepção de projeto de MDL analisados consideram que o quantitativo é suficiente em vista das dificuldades de obtenção de informações de despacho no Brasil. Além disso, os 23,6 \% restantes são plantas que não tem despacho coordenado pela ONS. Isto é, são plantas que operam com base nos acordos de compra as quais não estão sob controle das autoridades de despacho, ou estão localizadas em sistemas não interconectados aos quais a ONS tem acesso.

O impacto desta consideração é que o fator de emissão de todo o sistema elétrico brasileiro, considerando o SIN e o Sistema Isolado é superior ao fator calculado, principalmente pelo Sistema Isolado ter como as principais fontes primárias de energia, os combustíveis fósseis. No entanto empreendimentos conectados ao SIN não deslocam este tipo de geração, o que não afeta os projetos de MDL, o que justifica que este sistema não seja levado em consideração na determinação do fator de emissão. Porém, quando o Sistema Isolado em questão for interligado ao SIN, conforme prevê o PDEE, haverá um aumento do fator de emissão de operação na margem quando considerados todos os subsistemas ou o bloco N/NE. Portanto, para a análise dentro da área de influência desta pesquisa, o Estado de São Paulo onde as usinas encontram-se conectadas ao bloco $\mathrm{S} / \mathrm{SE} / \mathrm{CO}$, este fato não irá alterar os resultados encontrados.

Considerando a entrada de novas usinas termoelétricas no SIN, no médio e longo prazo, Reis e Pereira (2003) comentam que pelo tipo de tecnologia que a maioria das UTEs utilizam (ciclo combinado) e pela forma de contratação da energia que vem se empregando, a princípio, haverá despacho de UTEs para operar na base com a ressalva da predominância da energia hidráulica e termonuclear de Angra I e II. Tal fato implica que haverá um aumento do fator de emissão do SIN para os próximos períodos de análise. 


\section{CICLO PRODUTIVO DA CANA-DE-AÇÚCAR}

O desenvolvimento deste capítulo teve como referência a Tese de Doutorado "Avaliação do ciclo de vida $(A C V)$ do álcool etílico hidratado combustivel pelos métodos EDIP, Exergia e Emergia" (Ometto, 2005) da Escola de Engenharia de São Carlos (EESC) da Universidade de São Paulo (USP). Isto ocorre, pois foi a única referência bibliográfica encontrada que busca avaliar o ciclo de vida de um dos produtos do setor sucroalcooleiro e, neste caso em específico a produção do álcool. O que inclusive abrange o ciclo produtivo da cana-de-açúcar até a geração de eletricidade e etapas subseqüentes até a produção do álcool.

A principal vantagem é que as atividades relacionadas com preparo do solo, plantio da canade-açúcar, trato da cultura, colheita, o início do processo industrial (ex. lavagem e moagem) bem como a etapa de geração de energia térmica, mecânica e elétrica são comuns aos ciclos de vida dos produtos finais da usina (açúcar e/ou álcool), encaixando-se no escopo desta análise que é avaliação das externalidades no ciclo produtivo da cana-de-açúcar com ênfase na geração de energia elétrica. Em suma, deste estudo pode-se extrair informações relevantes sobre os subsistemas de interesse do setor com um nível de detalhamento e aprofundamento inerentes a uma Tese.

Ao mesmo tempo, a utilização desta referência se torna interessante visto que não só bagaço pode ser aproveitado para geração de eletricidade, mas existe também a possibilidade da utilização da vinhaça na geração de energia elétrica sob a perspectiva da utilização do biogás oriundo de um processo de biodigestão ou até mesmo como complemento para queima na caldeira como foi apresentado no capítulo anterior. A vinhaça encontra-se presente quando analisada a cadeia produtiva do álcool. A única limitação existente na presente análise é que não se pode avaliar quantitativamente as externalidades atreladas ao uso da vinhaça sob o aspecto da geração de eletricidade, pela ausência de dados quantitativos disponíveis na literatura.

O estudo contém uma valoração exergética, emergética e utilizou também método EDIP (Environmental Development of Industrial Products), brevemente descritos adiante, na avaliação e quantificação dos impactos elencados. A estrutura metodológica do trabalho baseou-se nas normas da série NBR ISO 14.040 e em métodos técnico-científicos adequados 
aos objetivos de avaliação dos impactos decorrentes da atividade produtiva. O método para a realização da ACV é o EDIP, utilizando-se para a fase da avaliação do impacto do ciclo de vida, além do método citado, dois métodos advindos da Termodinâmica: a exergia e emergia.

A vantagem de utilizar estes resultados na análise das externalidades do ciclo produtivo da cana sob o aspecto da geração de eletricidade é que os métodos selecionados complementamse de forma a expandir o horizonte de análise, o levantamento dos impactos e a quantificação dos mesmos. Outra vantagem é que os levantamentos das informações utilizaram dados de uma Usina localizada em Ribeirão Preto, no Estado de São Paulo. Além do mais, como o foco deste trabalho é a geração de eletricidade e a mesma é um subsistema intermediário da cadeia produtiva, não se faz necessário extrapolar o levantamento de dados com outros trabalhos da área, pois o foco não está nos produtos finais (açúcar / álcool). Deste modo, manter uma única referência torna a análise mais homogênea e passível de menos erros associados ao cruzamento de informações de diferentes referências bibliográficas e levantamentos em campo.

\subsection{ASPECTOS METODOLOGICOS}

A avaliação do ciclo de vida, segundo ABNT (2001), é a compilação e a avaliação das entradas, das saídas e dos impactos ambientais potenciais de um sistema de produto, o que pode incluir sistemas de serviço, ao longo de seu ciclo de vida. Um sistema de produto é definido como o conjunto de unidades de processo, conectadas, material e energeticamente, que realiza uma ou mais funções definidas.

De acordo com Barnthouse et al. (1997), os estudos de ACV originaram-se do objetivo de avaliar o uso dos insumos e da energia associadas aos sistemas produtivos. No entanto, no País, são poucos os estudos, normalmente desenvolvidos pelo meio acadêmicos ou por grandes empresas, sendo estas últimas de difícil acesso além de outro agravante que é o fato destes trabalhos serem elaborados em softwares de arquitetura fechada (proprietária).

A importância desta análise reside no auxílio à avaliação das externalidades ambientais e possíveis desdobramentos em outras áreas como, por exemplo, a socioeconômica além da 
possível avaliação da sustentabilidade dos subsistemas que compõem o ciclo produtivo da cana-de-açúcar.

A seguir, são apresentados alguns dos fundamentos teóricos dos métodos selecionados para a avaliação e quantificação dos impactos. Uma discussão mais aprofundada sobre avaliação de ciclo de vida bem como outras referências bibliográficas a cerca deste tema é encontrada em Ometto (2005).

\subsubsection{EDIP}

As categorias e seus indicadores bem como os modelos de caracterização dos impactos baseiam-se em Wenzel et al. (1997). Ometto (2005) selecionou as seguintes categorias indicadas pelo EDIP:

a) Consumo de recursos:

- Renováveis;

- Não-renováveis ${ }^{34}$; e, - Energia.

b) Potenciais de impactos ambientais:

- de aquecimento global;

- de formação fotoquímica de ozônio troposférico ${ }^{35}$;

- de acidificação ${ }^{36}$

- de eutrofização ${ }^{37}$

\footnotetext{
${ }^{34}$ Neste conceito se enquadram os recursos regeneráveis, mas com taxas praticamente insignificantes frente a quantidade disponível.

${ }^{35}$ Solventes e outros compostos orgânicos voláteis quando emitidos na atmosfera são freqüentemente degradados em alguns dias pela reação de oxidação, a qual ocorre sob a influência da luz do sol. Na presença de óxidos de nitrogênio $\mathrm{NO}_{\mathrm{x}}$, o ozônio pode ser formado. Os óxidos de nitrogênio não são consumidos durante a formação do ozônio, mas desempenham a função de catalisadores. Este processo ocorre na troposfera, a região mais baixa da atmosfera. $\mathrm{O}$ ozônio gera aumento na freqüência de problemas à saúde dos seres humano sendo um impacto que afeta o ambiente em escala local e regional. A substância de referência, assim como a unidade para tal impacto, é o eteno $\mathrm{C}_{2} \mathrm{H}_{4 \mathrm{eq}}$, representando o potencial de formação fotoquímica de ozônio troposférico. ${ }_{36}$ a unidade para tal impacto é o dióxido de enxofre equivalente $\left(\mathrm{SO}_{2 \text { eq }}\right.$, cujo impacto é local e regional.
} 
- de eco toxicidade; e,

- de toxicidade humana.

Além da segregação por categorias, há uma avaliação nos efeitos dos impactos quanto a sua abrangência espacial:

- locais oriundos de fontes individuais significativas e limitadas pela vizinhança imediata da fonte ou da influência do impacto;

- regionais oriundos de fontes difusas, isto é, não podem ser rastreados até se indicar um ponto gerador específico. Isto ocorre ou pela fonte estar distante dos efeitos ou pelo fato dos efeitos serem conseqüências de uma iteração adversa de pequenas fontes geradoras de impactos;

- globais são impactos que influenciam toda a Terra. As substâncias envolvidas nestes impactos possuem características de permanência no meio ambiente superiores às demais, o que possibilita uma maior mobilidade espacial. Consideram-se, também, emissões em grandes volumes e que sua diluição durante a dispersão no meio ainda causa efeitos sentidos globalmente. Como é o caso do efeito estufa.

No próximo capítulo, onde serão apresentados os conceitos de externalidades, é importante notar as semelhanças conceituais nas categorizações e segregações espaciais presentes no método EDIP com as categorias de externalidades estudadas pelo ExternE ${ }^{38}$ bem como as formas de avaliação dos agentes envolvidos sob a forma de externalidades alocáveis e nãoalocáveis.

\subsubsection{EXERGIA}

De acordo com Wark (1995), Szargut et al. (1988), Kotas (1995), Cornelissen (1997), Rosen e Dincer (1999) e Bejan (1988), a Exergia é fundamentada na segunda lei da Termodinâmica e pode ser definida como a quantidade máxima de trabalho mecânico internamente reversível, disponível em um fluxo de matéria ou energia, quando estes se deslocam de um estado de

\footnotetext{
${ }^{37}$ Os fatores de caracterização para o potencial de eutrofização são calculados para as substâncias que contenham nitrogênio $(\mathrm{N})$ ou fósforo $(\mathrm{P})$ a partir da forma como esses elementos estiverem disponíveis. A unidade de referência é a quantidade de nitrato equivalente $\mathrm{NO}_{3}^{-}$eq.

${ }^{38}$ A metodologia ExternE está detalhada no Anexo C.
} 
desequilíbrio físico e/ou químico para o ambiente-padrão de referência, trocando calor somente com o ambiente. O estado-padrão do ambiente de referência, ou estado de referência, é estabelecido pela temperatura, pela pressão e pela composição química do ambiente. Normalmente, são utilizadas as condições normais de temperatura e de pressão (CNTP) de $273 \mathrm{~K}$ e 1 atm, respectivamente, e a composição química mais estável do ambiente, a da atmosfera.

Segundo Kotas (1995), Bejan et al. (1996) e Szargut (1999), a Exergia total de uma substância pode ser dividida em: cinética, potencial, física e química. A Exergia cinética pode ser calculada pelo significado da velocidade em relação à superfície da Terra e o potencial pelo nível da vizinhança com relação ao sistema considerado. A Exergia física resulta da diferença entre a temperatura e a pressão em relação ao ambiente. Por fim, a exergia química vem da diferença entre a composição química dos componentes do sistema e a composição padrão do ambiente de referência.

Diversos modelos de ambiente de referência para cálculo da Exergia química têm sido propostos, sendo utilizado por Ometto (2005) o modelo de substâncias de referências usando o ambiente de referência padrão e os valores de Exergia química dados por Szargut et al. (1988). Tal uso se justifica pelo fato de o modelo ser um dos mais aceitos e utilizados pela comunidade científica internacional.

Ometto (2005) complementa a avaliação exergética das emissões atmosféricas com uma avaliação da Exergia físico-química da queimada da cana-de-açúcar, por meio do cálculo da exergia do combustível da biomassa da cana. Com isso, é avaliado e valorado o impacto atmosférico físico-químico direto dessas emissões, em termos da perda de trabalho mecânico disponível, em kJ, Na avaliação dos impactos do ciclo de vida, a exergia segue as orientações e os requisitos para a seleção de categorias de impacto, os indicadores de categoria e os modelos de caracterização de acordo com ISO (2000) e ABNT (2004). 
Tabela 4.1. Componentes do mecanismo ambiental pela Exergia. Fonte: (Ometto, 2005)

\begin{tabular}{ll}
\hline Componentes do mecanismo ambiental & \multicolumn{1}{c}{ Aplicação na Exergia } \\
\hline & Impacto atmosférico físico- \\
Categoria de impacto & químico direto \\
Resultados do impacto no ciclo de vida & Emissões atmosféricas \\
Modelo de caracterização & Exergia \\
Indicador de categoria & Perda de trabalho mecânico \\
& Trabalho mecânico disponível \\
Fator de caracterização & do gás de acordo com suas \\
& propriedades físico-químicas \\
& $\mathrm{kJ} / \mathrm{kg}$ gás \\
Resultado do indicador & $\mathrm{kJ}$ \\
Ponto final da categoria & Atmosfera \\
\hline Relevância ambiental & Espacial: global/regional \\
\hline
\end{tabular}

\subsubsection{EMERGIA}

O método da emergia, de acordo com Odum (1996), tem fundamentos na Termodinâmica, na Biologia, na Teoria Geral de Sistemas, oferecendo um grande potencial de aplicações na área socioambiental. Junto com outras ferramentas científicas modernas, o método apresenta-se como uma alternativa para avaliar os sistemas atuais e planejar sistemas mais sustentáveis.

O método baseia-se na definição de Emergia, que, segundo Scienceman (1989) e Odum (1996), é toda energia disponível que foi utilizada para a obtenção de um produto, incluindo os processos da natureza e os humanos. Essencialmente, Emergia pode ser concebida como a memória energética de um sistema, pois ela representa toda a energia incorporada de um sistema antrópico ou natural. Ou ainda, segundo Collins e Odum (2001), é um tipo de energia requerido para gerar outra forma de energia. Sua unidade é a energia solar equivalente sej ou emjoule emj.

O método da emergia considera todas as fontes de energia externas ao ciclo (renováveis e não renováveis) que são consumidas em diferentes tipos de processos. Dessa forma, pode estabelecer a quantidade de energia consumidas nos processos e compará-los com as suas respectivas eficiências. 
Tabela 4.2. Componentes do mecanismo ambiental pela Emergia. Fonte: (Ometto, 2005)

\begin{tabular}{|c|c|}
\hline Componentes do mecanismo ambiental & Aplicação na Emergia \\
\hline Categoria de impacto & Consumo de energia solar equivalente \\
\hline Resultados dos Impactos no ciclo de vida & $\begin{array}{l}\text { Consumo de recursos renováveis e não- } \\
\text { renováveis / consumo de energia e mão-de- } \\
\text { obra }\end{array}$ \\
\hline Modelos de Caracterização & Emergia \\
\hline Indicador de categoria & Energia solar equivalente incorporada \\
\hline Fator de caracterização & $\begin{array}{l}\text { Transformidade: quantidade de energia solar } \\
\text { equivalente incorporada na formação dos } \\
\text { insumos pela quantidade de produto sej / kg } \\
\text { produto }\end{array}$ \\
\hline Resultado do indicador & sej energia solar equivalente ou emj emjoules \\
\hline Pontos finais da categoria & $\begin{array}{l}\text { Energia solar, das marés e o calor interno da } \\
\text { Terra }\end{array}$ \\
\hline Relevância ambiental & Espacial: global \\
\hline
\end{tabular}

\subsubsection{AVALIAÇÃO CONJUNTA DOS MÉTODOS}

A grande diferença entre o EDIP, a Emergia e a Exergia é que o EDIP foi desenvolvido para a avaliação direta do potencial de impacto ambiental, de acordo com as propriedades das substâncias, enquanto os outros métodos são correlações entre o potencial energético de consumo e de perdas. Basicamente, a diferença centra-se nas categorias de impactos correspondentes e no procedimento de cálculo, segundo o mecanismo ambiental de cada modelo.

Métodos semelhantes ao EDIP e internacionalmente aceitos e utilizados com os quais o mesmo pode ser comparado diretamente, são: os holandeses Eco-indicator 99; e, CML 2001 (Life Cycle Assessment - An operational guide to the ISO Standards 2001). As maiores diferenças, segundo Ometto (2005) entre o EDIP e o CML 2001 encontram-se nas categorias de impacto: toxicidade humana e ecotoxicidade. Portanto, dependendo do estudo, o método utilizado para a avaliação de impactos no ciclo de vida é muito importante e pode definir a cadeia de resultados (Ometto, 2005). 
Com relação à Exergia, algumas discussões podem ser indicadas de acordo, respectivamente, com os pontos estabelecidos por Brown e Harendeen (1996):

1) o fato de a Exergia quantificar as perdas de trabalho útil e as eficiências reais de processos faz com que esta possa ser utilizada e destinada a ajustar as variáveis de processo, a fim de reduzir as perdas, aumentar a eficiência e, com isso, otimizar o processo;

2) com relação à possibilidade de quantificação de poluentes diretos e indiretos, avaliações energéticas são factíveis, se considerarmos, por exemplo, poluentes indiretos como os ocasionados por processos anteriores ao analisado, como por exemplo, por meio de estudo de ACV. De outro modo, com relação à Exergia, apesar de esta análise quantificar os impactos diretos físicos e químicos, por meio do trabalho absorvido pelo meio, os danos indiretos, assim como os impactos biológicos, sociais, econômicos e culturais que um poluente pode causar não são quantificados pela avaliação exergética;

3) a Exergia tem a capacidade, apesar de restrita à absorção físico-química direta, de quantificar o trabalho do ambiente na absorção e no processamento da poluição.

Tabela 4.3. Breve comparativo entre Energia, Exergia e Emergia. Fonte: [(Ometto, 2005) com adaptações]

\begin{tabular}{|c|c|c|}
\hline Energia & Exergia & Emergia \\
\hline $\begin{array}{l}\text { Depende do estado físico da } \\
\text { matéria sob consideração }\end{array}$ & $\begin{array}{l}\text { Depende do estado físico da } \\
\text { matéria sob consideração e do } \\
\text { estado de referência }\end{array}$ & $\begin{array}{l}\text { Depende do estado físico da } \\
\text { matéria sob consideração }\end{array}$ \\
\hline $\begin{array}{l}\text { Independe do caminho para } \\
\text { atingir determinado estado }\end{array}$ & $\begin{array}{l}\text { Independe do caminho para } \\
\text { atingir determinado estado }\end{array}$ & $\begin{array}{l}\text { Depende do caminho para } \\
\text { atingir determinado estado }\end{array}$ \\
\hline
\end{tabular}

A primeira diferença básica entre as duas avaliações, Exergia e Emergia, está na origem e na finalidade para a qual elas foram desenvolvidas. A Exergia, por sua vez, foi desenvolvida dentro da área da Engenharia Mecânica, a partir da Termodinâmica Clássica, com o objetivo de avaliar sistemas produtivos, principalmente energéticos, com foco na redução de perdas e ganhos de eficiência e melhorias no processo com relação à segunda lei da Termodinâmica.

Outra diferença apontada é quanto à desconsideração da Exergia no que se refere ao processo de formação ecológica dos recursos e dos serviços ambientais, considerados pela Emergia. 
Com relação à inclusão do trabalho humano e natural, a avaliação emergética os inclui como mão-de-obra e recursos naturais, respectivamente, enquanto, apesar de as avaliações energéticas clássicas, como a Exergia, poderem contabilizá-los, dificilmente se encontra análises com tais considerações (Ometto, 2005).

Em análises Termodinâmicas de sistemas Brown e Harendeen (1996), indicam que a Emergia assume maior importância nos componentes das posições superiores da hierarquia do sistema, enquanto as avaliações energéticas e exergéticas assumem valores de maiores importâncias para os componentes iniciais.

Desse modo, para Ometto (2005) no que se refere à avaliação e à quantificação do impacto ambiental, indica-se a utilização da emergia e da exergia de forma complementar.

\subsection{CICLO PRODUTIVO DA CANA-DE-AÇÚCAR}

\subsubsection{CARACTERIZAÇÃO QUALITATIVA}

As etapas do ciclo de vida avaliadas por Ometto (2005) são: o preparo do solo e o cultivo agrícola da cana-de-açúcar; o transporte interno; o processo industrial; a reutilização dos resíduos e dos efluentes industriais; a geração de vapor e de energia elétrica; a armazenagem e distribuição; assim como a utilização do álcool etílico hidratado combustível.

A fase agrícola do processo canavieiro, admitindo que a área já tenha histórico de uso agrícola, inicia-se, de acordo com o Instituto Agronômico de Campinas (IAC) (1994), pelas operações de limpeza do terreno, de nivelamento de solo, de estudos de sua qualidade, de aração e de gradagem. Após a adequação e avaliação das condições físicas do solo, inicia-se o preparo do solo, que, segundo Castro (1985) e Ometto, D. (2000), pode ser visto como uma série de operações que têm por finalidade prover condições físico-químico-biológicas ao solo para o cultivo.

Segundo Ometto (2005), a conservação do solo ocorre pela aplicação de técnicas do preparo, tais como: a incorporação da matéria orgânica, as curvas de nível e a eliminação das camadas compactas para o aumento da infiltração de água no solo. O preparo periódico do solo ocorre 
para o plantio da cana-de-açúcar. Após o primeiro corte, ocorre o preparo para a cana soca, o qual se repete, geralmente, por quatro ou cinco cortes quando o ciclo se completa e ocorre a renovação do canavial, pelo replantio.

Neste momento, a renovação do canavial pode ocorrer pelo modo mecânico, químico ou um combinado entre ambos. Para o modo mecânico, Ometto, D. (2000) enumera as seguintes operações: aração e gradagem ou gradagem pesada, subsolagem, sulcamento e adubação. $\mathrm{O}$ preparo do solo de modo convencional, ainda na renovação do canavial segundo Freitas (1987), pode ser ordenado nas seguintes operações:

1. limpeza, enleiramento e queima da palha;

2. calagem $^{39}$;

3. grade pesada para erradicação da soqueira;

4. operações de conservação de solo;

5. gradagens subseqüentes;

6. sistematização;

7. subsolagem com aletas (em áreas que exijam esta operação);

8. gradeação pesada; e,

9. gradagem leve de pré-plantio.

Segundo Castro (1985), o preparo convencional do solo antes do plantio pode, também, ser dividido em primário: aração, desmatamento e operações com rolo faca; e secundário: nivelamento do terreno, incorporação de herbicidas, eliminação de ervas invasoras com o uso de gradagem e/ou enxada rotativa.

De acordo com Ometto (2000), a operação de plantio pode ser manual ou mecanizada, de modo direto ou convencional. No método de plantio direto, o sulco é feito por meio de um sulcador que atua sobre a palhada remanescente, enquanto, no convencional, o terreno é preparado por operações de aração e gradagem, seguidas do sulcador no solo sem palha. $\mathrm{O}$

\footnotetext{
${ }^{39}$ Quando as quantidades de cálcio e/ou magnésio trocáveis do solo estiverem em níveis insuficientes, ou quando o solo apresentar altos teores de alumínio tóxico;
} 
sulco é um canal de aproximadamente 25 a $30 \mathrm{~cm}$ de profundidade, no qual a muda de canade-açúcar é colocada. Quando o solo é impermeável e muito compactado, utiliza-se a subsolagem para romper esse horizonte de impedimento e para facilitar o desenvolvimento e a penetração das raízes no solo.

O plantio é realizado, prioritariamente, de modo manual, com o auxílio de um caminhão, o qual carrega a cana; em seguida são arremessadas no sulco enquanto funcionários a picam em toletes. Este modo, em conjunto com o preparo convencional de erradicação da soqueira, seja mecânico ou químico, são os mais usuais na cultura canavieira.

Após o plantio, iniciam-se os tratos culturais que, segundo Corbini (1987), são práticas agrícolas que visam:

- preservar ou restaurar as propriedades físicas e químicas do solo;

- eliminar ou reduzir a concorrência das plantas invasoras;

- conservar o sistema de controle de erosão; e,

- controlar pragas ou doenças, eventualmente.

De acordo com Corbini (1987), as operações de controle das ervas concorrentes podem ser:

- preventivas, como levantamento das infestações para a identificação precoce de pequenos focos;

- culturais, pela cobertura total do solo e por práticas de rotação com adubos;

- mecânico, podendo ser manual, com a utilização da enxada; animal, no qual os cultivadores são tracionados por animais e mecanizada por tratores;

- cultivo químico, herbicidas

Segundo o IAC (1994), os tratos culturais incluem a utilização de agrotóxicos e, quando necessário, a adubação. De acordo com Ometto, A. (2000), os principais agrotóxicos aplicados na lavoura da cana-de-açúcar são:

- Aldrin: para Mello (1997), é um organoclorado utilizado para combater nematóides e insetos. A utilização de organoclorado é proibida em diversos países pelo seu poder 
residual e acumulativo na cadeia alimentar. O tempo para o desaparecimento de $95 \%$ da quantidade aplicada varia de 5 a 7 anos, podendo o agrotóxico permanecer no solo por 10 a 12 anos;

- Ametrina: herbicida com nomes comerciais de Gesapax, Herbipax e Metrimex;

- Atrazina: herbicida para controlar gramíneas anuais e latifoliadas;

- Clorpirifuos: inseticida considerado tóxico;

- 2,4 D: segundo Arevalo (1980), herbicida do grupo químico dos fenoxis;

- Diflubenzuron: inseticida de baixa toxicidade;

- Diuron: segundo Arevalo (1980), herbicida do grupo da uréia, de baixa toxicidade;

- Finitrotin: inseticida de baixa toxicidade;

- Hexazinone: herbicida conhecido comercialmente como Velar K;

- Paration metil: componente ativo de alguns pesticidas organo-fosforados. Sua ação baseia-se em matar os insetos provocando o bloqueio dos impulsos nervosos. É banido dos EUA, pela Agência de Proteção Ambiental norte-americana (EPA);

- Glifosato: comercialmente conhecido como Roundup;

- Simazina: herbicida com nomes comerciais de Topeze e Simetrex SC;

- Tebuthiuron: segundo Victoria (1993), constitui um herbicida de nome comercial Perflan e Combine;

- Telrithiuron;

- Velpark.

Após as aplicações de herbicidas, a próxima etapa do ciclo de vida analisado, ainda nas operações agrícolas, é a fase da colheita, na qual se utiliza a prática da queima da palha da cana-de-açúcar, prévia ao corte, em $75 \%$ das áreas com cana no Estado de São Paulo, 
segundo Macedo et al. (2004). Silva (1998) explica o processo da queima da palha da canade-açúcar em três fases:

1. Ignição: o início do processo, na presença de oxigênio e baixas temperaturas. Esta fase é rápida e apresenta, ainda, baixa concentração de poluentes;

2. Combustão incompleta: atinge altas temperaturas e forma gases tóxicos, como $\mathrm{CO}_{2}, \mathrm{NO}_{\mathrm{x}}$ (óxido de nitrogênio) e $\mathrm{SO}_{\mathrm{x}}$ (óxido de enxofre), entre outros.

3. Resfriamento: a última etapa da queima, caracterizada pela diminuição da temperatura e pela liberação de materiais particulados, hidrocarbonetos policíclicos aromáticos (HPAs) e outras substâncias orgânicas provenientes dessa combustão incompleta.

A etapa da fabricação do álcool inicia-se com a entrada da cana-de-açúcar na usina, descarregada por caminhões, em esteiras que as conduzem às etapas do processo industrial.

Segundo Ometto (2000), logo no início do processo industrial, a cana já é lavada com água, para a retirada do material incorporado ao colmo durante o corte e o transporte do campo à usina, surgindo o primeiro efluente: a água de lavagem de cana. Algumas usinas descartam esta operação, principalmente quando é utilizado o corte da cana crua, pois, como o colmo não exsuda ${ }^{40}$, não retém tanta sujeira como o colmo que sofre exsudação com a queimada, o qual, ainda, perde sacarose.

A eliminação dessa operação contribui para a redução de custos ambientais e econômicos pela não-utilização excessiva de água, já que, segundo Braile e Cavalcanti (1979), essa etapa do processamento industrial consome, em média, 3 a $7 \mathrm{~m}^{3}$ de água por tonelada de cana.

Logo após a lavagem, a matéria-prima do processo industrial, a cana-de-açúcar, é submetida a uma série de facas e desfibradores para aumentar a eficiência de extração do caldo nas moendas, as quais são movidas, principalmente, por turbinas a vapor, proveniente da queima do bagaço nas caldeiras; ou por motores elétricos ou hidráulicos.

O caldo produzido durante a moagem é composto, segundo Braile e Cavalcanti (1979), por uma solução contendo sacarose, açúcares redutores e não-açúcares. Esse caldo passa por um tratamento, por aquecimento e decantação, subdividindo-se, no processo de produção, em açúcar e em álcool, quando a usina gera os dois produtos.

\footnotetext{
${ }^{40}$ Exudação significa segregar ou sair em forma de gotas, neste contexto.
} 
O lodo resultante da decantação é submetido à filtração a vácuo. O líquido da filtração retorna ao processo e os resíduos sólidos, conhecidos como torta de filtro são destinados à fertilização nos campos de cultivo de cana-de-açúcar.

A continuação da descrição do processo industrial é focada na produção do álcool a partir do caldo obtido no processo de extração e enviado diretamente para a fabricação do álcool, pelo fato de o estudo de Ometto (2005) não contemplar a produção de açúcar. Entretanto, cabe diferenciar os dois tipos de destilarias de etanol:

a) destilarias anexas: que produzem álcool também a partir do produto da fermentação do melaço, subproduto da produção de açúcar, o chamado mosto de melaço;

b) destilarias autônomas: nas quais o álcool é obtido a partir da fermentação direta do caldo de cana.

O caldo, enriquecido com alguns nutrientes, é inoculado, de acordo com Braile e Cavalcanti (1979), com leveduras (fungo) do gênero Saccharomyces. Tais microorganismos irão reverter a sacarose e transformá-la em álcool etílico ou etanol e dióxido de carbono.

O produto da fermentação é um substrato açucarado, denominado vinho, que é centrifugado para a obtenção e a reutilização das leveduras, enquanto o líquido é enviado às colunas de destilação. Na primeira coluna, obtém-se álcool de $45{ }^{\circ} \mathrm{GL}$ (fração em volume) a $50{ }^{\circ} \mathrm{GL}$, denominado flegma ${ }^{41}$, e o efluente, que, segundo o IAC (1994), é responsável por mais de 60 $\%$ da carga poluidora de uma destilaria: a vinhaça. Na coluna seguinte, de retificação ${ }^{42}$, a concentração eleva-se à, no máximo, $97^{\circ} \mathrm{GL}$, segundo Almeida 1997, sendo encontrado pela FIC (2004) na fração em massa do álcool na mistura de 93,2 \% (mínimo 92,6 \% e máximo $93,8 \%$ ). Este produto é o álcool etílico hidratado combustível o qual foi o produto focado por Ometto (2005) em seu trabalho.

A geração de vapor é realizada a partir da queima do bagaço nas caldeiras sendo que este vapor é utilizado tanto para: acionamento mecânicos, como por exemplo, moendas; processos que demandem energia térmica (calor); quanto para gerar eletricidade.

\footnotetext{
${ }^{41}$ A flegma segue para a coluna de retificação e de esgotamento obtendo-se flegmaça como produto de fundo e álcool hidratado como produto de topo (Camargo, 1990).

${ }^{42} \mathrm{O}$ processo de retificação tem a função de eliminar do álcool fraco ou flegma todas as impurezas e concentrar o

álcool assim purificado, chamado retificado ou hidratado, com graduação até $97^{\circ} \mathrm{GL}$.
} 
A energia elétrica gerada, como foi visto no capítulo anterior, pode suprir apenas a demanda interna da usina e, quando gerada em excedentes, estes serem comercializados diretamente no SIN ou em sistemas de subtransmissão e distribuição.

A reutilização de subprodutos no ciclo de vida do álcool é caracterizada pela fertirrigação da vinhaça e torta de filtro nos campos de cultivo. A vinhaça ou vinhoto, como visto, é resultante da produção do álcool, após a fermentação do mosto e a destilação do vinho. Segundo Unido (1997) e Cetesb (1985), a vinhaça é o maior poluidor dentre os efluentes, variando seu desprendimento, dependendo da concentração (teor) alcoólica obtida na fermentação, de 10 a 18 litros de vinhaça por litro de álcool produzido, com altas temperaturas na saída dos destiladores, as quais variam de $85^{\circ} \mathrm{C}$ a $90^{\circ} \mathrm{C}$.

Quanto à composição, a vinhaça apresenta características específicas, bem estudadas por vários autores, e as quais variam conforme alguns fatores, segundo Cruz (1991), tais como: natureza e composição da matéria-prima, do mosto, do vinho, do tipo de equipamento e da condução da destilação.

Contudo, a riqueza organo-mineral é alta em todas as condições, tendo grande importância na aplicação em solos agrícolas. Portanto, sua utilização nas lavouras de cana-de-açúcar, em substituição parcial ou total à adubação organo-mineral, tem sido largamente ampliada. Todavia Szmrecsányi (1994) afirma que o seu uso não pode ser excessivo nem indiscriminado, sob pena de comprometer o meio ambiente, com a salinização do solo e poluição dos aqüíferos, e a própria rentabilidade agrícola e industrial.

O transporte da vinhaça pode ser realizado por caminhões, canais abertos ou bombeados, realizando-se a aplicação, geralmente, por aspersão.

A armazenagem do álcool é feita em tanques e a distribuição do etanol é realizada, por meio de caminhões a diesel, até os postos de gasolina. O uso do etanol hidratado ocorre pela sua combustão em veículos automotores.

O ciclo fecha-se com a absorção, pela cana-de-açúcar, durante seu crescimento, do $\mathrm{CO}_{2}$ proveniente de recursos renováveis e emitidos na combustão e demais fases do ciclo de vida do álcool. A seguir um fluxograma simplificado é apresentado, identificando os processos mais relevantes juntamente com suas entradas e saídas. 


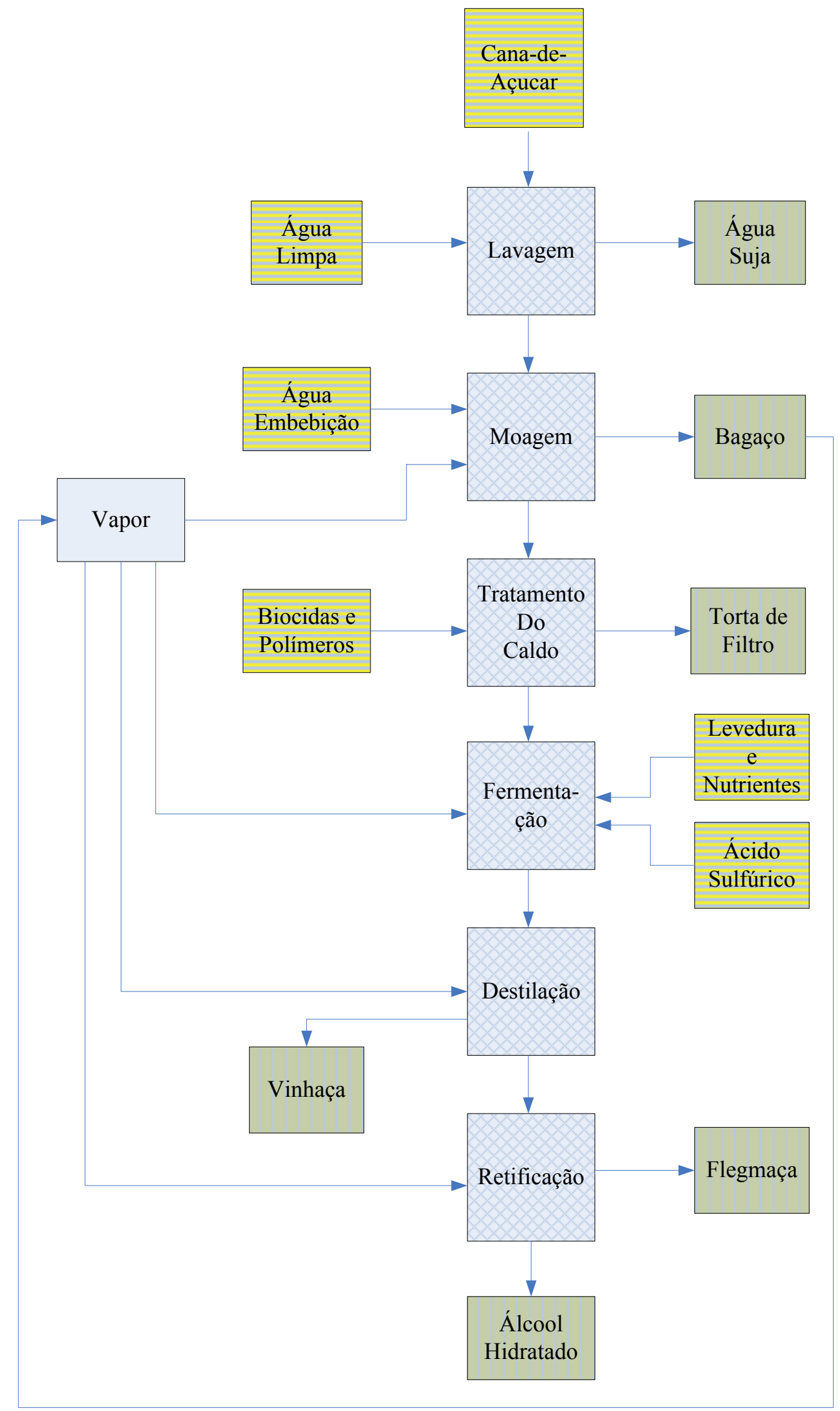

Figura 4.1. Fluxograma simplificado do processo industrial do álcool etílico hidratado. Fonte: (Ometto, 2005) Adaptado 


\subsubsection{CARACTERIZAÇÃO QUANTITATIVA}

O objetivo de uma análise quantitativa é avaliar os potenciais de impactos de cada atividade, valorar os insumos e as emissões do ciclo e indicar oportunidades de melhorias ambientais. A unidade de referência para o trabalho é de 1,0 t ou 12501 de álcool hidratado. Os dados foram levantados de uma usina convencional na região de Ribeirão Preto, Estado de São Paulo.

A atividade produtiva foi subdividida em unidades de processo ou subsistemas que compõem todo o sistema produtivo em análise, sendo destacados os subsistemas de interesse:

Atividade 1: Preparo do solo;

Atividade 2: Plantio da cana-de-açúcar;

Atividade 3: Tratos culturais;

Atividade 4: Colheita da cana-de-açúcar;

Atividade 5: Processo industrial do álcool etílico hidratado combustível: o qual é composto pelas atividades de moagem da cana, de tratamento do caldo, de fermentação e de destilação. Os produtos da moagem da cana são o caldo, a torta de filtro e o bagaço. O caldo é usado para produzir álcool; a torta de filtro é usada como fertilizante, junto com a vinhaça, na área agrícola e o bagaço é utilizado para a geração de vapor e de energia elétrica a usar no processo industrial do álcool. Os produtos finais da destilação são o álcool e a vinhaça, a qual é usada como fertilizante na fertirrigação da área de cultivo da cana-de-açúcar;

Atividade 6: Geração de vapor e de energia elétrica;

\section{Atividade 7: Fertirrigação;}

Neste trabalho, as atividades "8: Distribuição do álcool etílico hidratado combustível" e "9: Utilização do álcool etílico hidratado combustível" não foram consideradas por não fazerem parte do escopo desta análise. A seguir serão apresentadas as considerações essenciais ao entendimento dos resultados.

Para o autor, as rotações de culturas não foram consideradas, pois os respectivos dados não influenciariam a avaliação do ciclo de vida, pelo fato da rotação de cultura apenas auxiliar na manutenção da produtividade média da cultura, segundo Neto et al (2002). 
Além destas atividades, Ometto (2005) considerou além das nove unidades de processo indicadas, as etapas de extração de calcário $\left(\mathrm{CaCO}_{3}\right)$, pois a quantidade está acima do critério de corte estabelecido pelo autor e a cadeia de produção do fertilizante fosfatado $\left(\mathrm{P}_{2} \mathrm{O}_{5}\right)$ por apresentar alto potencial de impacto ambiental e por ser largamente utilizado no Brasil. O diesel também foi avaliado por apresentar também impactos ambientais bem como todo insumo e emissão das unidades de processo consideradas. A armazenagem do álcool inicialmente foi considerada pelo autor, mas foi verificado que não apresentava nenhum aspecto ambiental considerável, não sendo incluído nos resultados.

Considera-se a produtividade média ponderada dos cortes de cana-de-açúcar em toneladas por hectare de área plantada, incluindo a área de renovação do canavial; 79,5 1 de álcool por tonelada de cana e massa específica do álcool, a $25{ }^{\circ} \mathrm{C}$, como $0,8 \mathrm{~kg} / \mathrm{l}$, segundo o Ministério de Ciência e Tecnologia (2003). Para o tratamento dos dados, considera-se, portanto, que são necessárias $15.723,27 \mathrm{~kg}$ de cana para a produção da quantidade supracitada de álcool $(1 \mathrm{t})$, o que corresponde a, aproximadamente, 0,24 ha. Como os dados foram calculados pela massa, a transformação dos dados dos produtos utilizados em litros é realizada por meio da concentração média encontrada na pesquisa bibliográfica da composição e da massa específica dos mesmos.

Os dados do inventário e a avaliação dos impactos do consumo de diesel dos tratores, caminhões, equipamentos agrícolas e ônibus são considerados, porque são utilizados em muitas atividades e, com isso, seus impactos são importantes para todo o ciclo. Foi considerada a massa específica média do óleo diesel igual a $0,85 \mathrm{~kg} / 1$, segundo o Ministério de Ciência e Tecnologia (2003). 


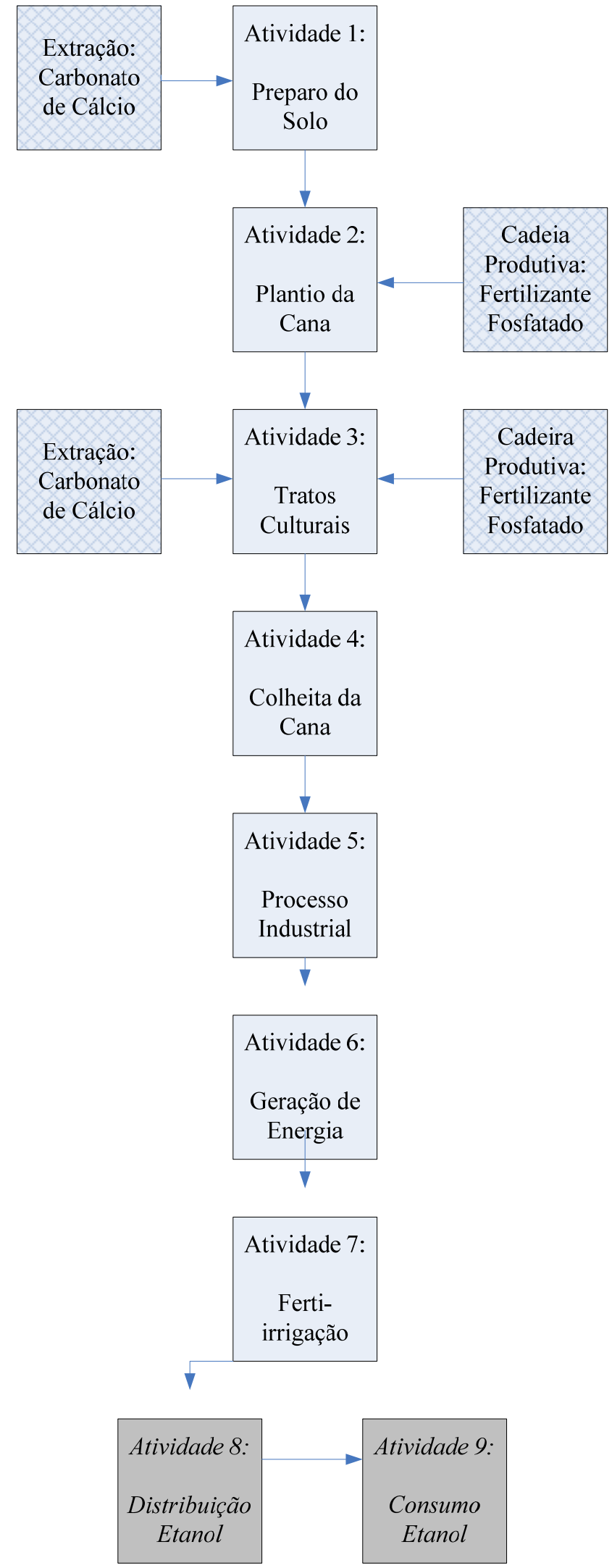

Figura 4.2. Sistemas do ciclo produtivo. Fonte: (Ometto, 2005) Adaptado 
Os dados utilizados pelo estudo de Ometto (2005) foram coletados de fontes: primárias amostra direta do processo analisado na usina de referência no Estado de São Paulo, a qual foi considerada pelo autor por possuir um nível tecnológico tradicional entre os anos de 2001 a 2004; secundárias - revisão bibliográfica e entrevistas e por algumas considerações realizadas por especialistas do setor.

À exceção dos dados da extração do carbonato de cálcio $\left(\mathrm{CaCO}_{3}\right)$ e do consumo de diesel nos tratores, caminhões e ônibus os demais dados foram obtidos por Ometto (2005) a partir do banco de dados do EDIP, com o uso do software SIMAPRO ${ }^{\circledR}$. Os dados do consumo de diesel são avaliados com base na distância percorrida pelo veículo a diesel e pela carga transportada. Os dados de peso da carga e de distância percorrida são de fonte primária. A origem dos dados primários é datada de até cinco anos.

Para a avaliação da ecotoxicidade pelo EDIP, a aplicação de pesticida no solo é considerada como impacto para o compartimento do solo, visto como um recurso biológico e não do sistema de produção. O resultado disso é que esses valores são uma estimativa do máximo impacto causado na primeira aplicação do pesticida no solo in natura e que todo pesticida aplicado em uma determinada área nela permaneça.

Com relação à formação fotoquímica de ozônio troposférico, como grande parte das atividades ocorrem em zona rural consideram-se os fatores de equivalência para áreas com baixa concentração de $\mathrm{NO}_{\mathrm{x}}$.

Para a avaliação pelo método EDIP, o $\mathrm{CO}_{2}$ é um gás de efeito estufa. Este efeito é um impacto considerado global. Considera-se que a quantidade de $\mathrm{CO}_{2}$ emitido pelos processos que envolvem subprodutos da cana seja absorvida pela fotossíntese da planta durante seu crescimento. Portanto, para a avaliação do potencial de efeito estufa, o $\mathrm{CO}_{2}$ emitido pela queimada da cana-de-açúcar (na atividade 4), pela fermentação do álcool (na atividade 5), pela queima do bagaço nas caldeiras (na atividade 6) e na utilização do álcool (atividade 9) não são considerados. 


\subsubsection{RESULTADOS - MÉTODO EDIP}

\section{EMISSÕES ATMOSFÉRICAS}

Tabela 4.4. - Quantidade de substâncias atmosféricas emitidas por tonelada de álcool. Incluído o $\mathrm{CO}_{2}$ emitido pela queimada e pela geração de vapor e eletricidade. Fonte:

(Ometto, 2005)

\begin{tabular}{|c|c|c|c|c|c|c|c|c|c|}
\hline \multirow{2}{*}{$\begin{array}{c}\text { Substância } \\
\text { Emitida Para } \\
\text { Atmosfera }\end{array}$} & \multicolumn{8}{|c|}{ Atividade $\mathrm{kg} / \mathbf{t}_{\text {álcool }}$} & \multirow{2}{*}{$\begin{array}{c}\text { Total } \\
\text { kg / } \\
\text { tálcool }\end{array}$} \\
\hline & 1 & 2 & 3 & 4 & 6 & 7 & 8 & 9 & \\
\hline $\mathrm{CO}_{2}$ & 1,975 & 1,283 & 3,191 & $5.895,51$ & $2.307,03$ & 0,937 & 0,519 & 0 & $8.210,45$ \\
\hline$N O_{x}$ & 0,019 & 0,016 & 0,046 & 10,815 & 1,485 & 0,013 & 0,008 & 10,9 & 23,303 \\
\hline$C O$ & 0,006 & 0,005 & 0,009 & 303,031 & 0,495 & 0,002 & 0,002 & 188 & 491,549 \\
\hline $\mathrm{SO}_{2}$ & 0,004 & 0,002 & 0,025 & 0,186 & 0 & 0,001 & 0,001 & 0 & 0,219 \\
\hline$H C$ & 0,001 & 0,002 & 0,005 & 60,497 & 0 & 0,002 & 0,002 & 15,6 & 76,109 \\
\hline $\mathrm{NO}_{2}$ & 0 & 0,004 & 0 & 0,293 & 0 & 0 & 0 & 0 & 0,297 \\
\hline$S O_{x}$ & 0,001 & 0,0004 & 0,0005 & 0,011 & 0 & 0,0003 & 0 & 0 & 0,013 \\
\hline Tolueno & 0 & 0,00003 & 0 & 0,002 & 0 & 0 & 0 & 0 & 0,002 \\
\hline $\mathrm{N}_{2} \mathrm{O}$ & 0,0003 & 0,081 & 0,151 & 0 & 0 & 0,02 & $7 \mathrm{E}-06$ & 0 & 0,252 \\
\hline$K^{43}$ & 0 & 0 & 0 & 1,26 & 0 & 0 & 0 & 0 & 1,26 \\
\hline$C a^{43}$ & 0 & 0 & 0 & 2,16 & 0 & 0 & 0 & 0 & 2,16 \\
\hline$M g^{43}$ & 0 & 0 & 0 & 0,522 & 0 & 0 & 0 & 0 & 0,522 \\
\hline$S^{43}$ & 0 & 0 & 0 & 0,576 & 0 & 0 & 0 & 0 & 0,576 \\
\hline $\mathrm{CH}_{4}$ & 0,001 & 0,0003 & 0,001 & 5,106 & 0 & 0,00002 & 0 & 0 & 5,108 \\
\hline Total $\mathrm{kg} / \mathbf{t}_{\text {álcool }}$ & 2,007 & 1,393 & 3,429 & $6.279,97$ & $2.309,01$ & 0,974 & 0,533 & 214,5 & $8.811,82$ \\
\hline
\end{tabular}

As maiores quantidades de emissões atmosféricas referentes ao ciclo produtivo em questão estão distribuídas entre a fase de colheita da cana (atividade 4) e pela geração de vapor (calor) e de energia elétrica (atividade 6), com base no fluxo de referência. E de todas as atividades, a 4 (colheita de cana-de-açúcar) é a que apresenta a maior emissão atmosférica de todo o ciclo de vida do álcool, isto ocorre por causa da prática da queimada da cana. Ressalta-se que os dióxidos de carbono proveniente das etapas queimada da palha, do uso energético do bagaço, da fermentação e utilização do álcool, são reabsorvidos durante o crescimento do cultivo. Contudo, é importante destacar que tal absorção, segundo Ometto (2000), é realizada durante

\footnotetext{
${ }^{43}$ Substâncias associadas com às emissões de particulados.
} 
um ano ou um ano e meio, enquanto a emissão da queimada da palha da cana ocorre em alguns minutos e de forma difusa.

A quantidade de $\mathrm{CO}_{2}, \mathrm{CO}$, hidrocarbonetos e $\mathrm{NO}_{\mathrm{x}}$ ocorrem pela utilização de diesel nas máquinas agrícolas, nos caminhões e nos ônibus, além das emissões na queima de cana e do bagaço na caldeira.

Tabela 4.5. - Porcentagem das emissões atmosféricas mais relevantes do ciclo de vida do álcool considerando o $\mathrm{CO}_{2}$ da queimada e do uso do energético do bagaço. Fonte:

(Ometto, 2005)

\begin{tabular}{cc}
\hline Substância & \% \\
\hline $\mathrm{CO}_{2}$ & $93,17540 \%$ \\
$\mathrm{CO}$ & $5,57829 \%$ \\
$\mathrm{HC}$ & $0,86372 \%$ \\
$\mathrm{NO}_{x}$ & $0,26445 \%$ \\
$\mathrm{CH}_{4}$ & $0,05797 \%$ \\
$\mathrm{Ca}$ & $0,02451 \%$ \\
$\mathrm{~K}$ & $0,01430 \%$ \\
$\mathrm{~S}$ & $0,00654 \%$ \\
$\mathrm{Mg}$ & $0,00592 \%$ \\
$\mathrm{NO}_{2}$ & $0,00337 \%$ \\
$\mathrm{~N}_{2} \mathrm{O}$ & $0,00286 \%$ \\
$\mathrm{SO}_{2}$ & $0,00249 \%$ \\
$\mathrm{SO}_{x}$ & $0,00015 \%$ \\
$\mathrm{Tolueno}$ & $0,00002 \%$ \\
\hline
\end{tabular}

Tabela 4.6. - Porcentagem das maiores emissões atmosféricas do ciclo de vida do álcool desconsiderando o $\mathrm{CO} 2$ da queimada da palha, do uso energético do bagaço, da fermentação e utilização do álcool

\begin{tabular}{cc}
\hline Substância & \% \\
\hline $\mathrm{CO}$ & $80,67769 \%$ \\
$\mathrm{HC}$ & $12,49173 \%$ \\
$\mathrm{NOx}$ & $3,82471 \%$ \\
$\mathrm{CO}_{2}$ & $1,29744 \%$ \\
$\mathrm{CH}_{4}$ & $0,83837 \%$ \\
$\mathrm{~K}$ & $0,20680 \%$ \\
$\mathrm{Ca}$ & $0,35452 \%$ \\
& continua...
\end{tabular}


Tabela 4.6. - Porcentagem das maiores emissões atmosféricas do ciclo de vida do álcool desconsiderando o $\mathrm{CO} 2$ da queimada da palha, do uso energético do bagaço, da fermentação e utilização do álcool

\begin{tabular}{|c|c|}
\hline Substância & $\%$ \\
\hline$S$ & $0,09454 \%$ \\
\hline$M g$ & $0,08568 \%$ \\
\hline $\mathrm{NO}_{2}$ & $0,04875 \%$ \\
\hline $\mathrm{N}_{2} \mathrm{O}$ & $0,04136 \%$ \\
\hline $\mathrm{SO}_{2}$ & $0,03594 \%$ \\
\hline$S O_{x}$ & $0,00213 \%$ \\
\hline Tolueno & $0,00033 \%$ \\
\hline
\end{tabular}

\section{CONSUMO DE RECURSOS RENOVÁVEIS}

Como se observa na tabela abaixo, as atividades de produção industrial do álcool (atividade 5) e de geração de vapor e de energia elétrica (atividade 6) são as maiores consumidoras de recursos naturais renováveis, por causa, principalmente, do alto consumo de água desses processos. A atividade 5 apresenta a atividade de lavagem da cana como a de maior consumo de água ${ }^{44}$.

Tabela 4.7. - Consumo de recursos renováveis. Fonte: (Ometto, 2005)

\begin{tabular}{cr}
\hline Atividade & $\begin{array}{c}\text { Consumo de } \\
\text { Recursos } \\
\text { Renováveis } \\
\text { kg / tálcool }\end{array}$ \\
\hline 1 & 8482,92 \\
2 & 697,74 \\
3 & 5706,4 \\
4 & 1,29 \\
5 & $131.949,40$ \\
6 & $14.625,27$ \\
7 & 180,82 \\
8 & 0 \\
9 & 0 \\
Total & $161.643,84$ \\
\hline
\end{tabular}

\footnotetext{
${ }^{44}$ Ressalta-se que grande parte do volume de água consumida é reciclada na própria usina.
} 


\section{CONSUMO DE RECURSOS NÃO-RENOVÁVEIS}

Tabela 4.8. - Consumo de recursos não-renováveis. Fonte: (Ometto, 2005)

\begin{tabular}{cr} 
Atividade & $\begin{array}{c}\text { Consumo de Recursos } \\
\text { Não-Renováveis } \\
\mathbf{k g} / \mathbf{t}_{\text {álcool }}\end{array}$ \\
& \\
\hline 1 & 100,77 \\
2 & 18,88 \\
3 & 151,97 \\
4 & 63,91 \\
5 & 11,81 \\
6 & 0,01 \\
7 & 47,02 \\
8 & 1,475 \\
9 & 0 \\
Total & 395,83 \\
\hline
\end{tabular}

De acordo com a tabela acima, observa-se que as maiores consumidoras de recursos nãorenováveis são as atividades de tratos culturais (atividade 3), de preparo do solo (atividade 1) e de colheita de cana (atividade 4), devido ao alto uso de agroquímicos e do consumo de diesel nas máquinas agrícolas, nos caminhões e nos ônibus. $\mathrm{O}$ fator que pesa na atividade 7 , que também se destacou, é o uso de agroquímicos.

\section{CONSUMO DE ENERGIA}

De acordo com a tabela abaixo, a atividade de produção industrial do álcool (atividade 5) é a maior consumidora de energia, principalmente a elétrica seguida da térmica. No entanto, a geração de energia através da atividade 6 supre essa demanda com a presença de excedente 
em todo o ciclo (indicado pelo sinal negativo). Este resultado não considera a perda de energia pela queimada e pelas demais emissões atmosféricas.

Tabela 4.9. - Consumo de energia. Fonte: (Ometto, 2005)

\begin{tabular}{cr}
\hline Atividade & \multicolumn{1}{c}{$\begin{array}{c}\text { Consumo de } \\
\text { Energia } \\
\text { MJ / tálcool }\end{array}$} \\
\hline 1 & 0,001 \\
2 & 1,11 \\
3 & 16,85 \\
4 & 100,75 \\
5 & $1.238,40$ \\
6 & $-2.439,90$ \\
7 & 1,75 \\
8 & 0,57 \\
9 & 0 \\
Total & $-1.080,47$ \\
\hline
\end{tabular}

POTENCIAL DE AQUECIMENTO GLOBAL

Tabela 4.10. - Potencial de aquecimento global. Fonte: (Ometto, 2005)

\begin{tabular}{cr}
\hline Atividade & \multicolumn{2}{c}{$\begin{array}{c}\text { Potencial de } \\
\text { aquecimento global } \\
\text { kg CO } \mathbf{O}_{\text {2eq }} / \mathbf{t}_{\text {álcool }}\end{array}$} \\
& \\
\hline 1 & 2,1 \\
2 & 27,09 \\
3 & 51,22 \\
4 & 1029,4 \\
5 & 0,00 \\
6 & 0,99 \\
7 & 7,21 \\
8 & 0,53 \\
9 & 422,8 \\
Total & $1.541,34$ \\
\hline
\end{tabular}


Como apresentado na tabela acima, a atividade 4 que trata da colheita de cana-de-açúcar, é a que maior potencial para o efeito estufa, devido, principalmente, aos gases hidrocarbonetos, metano e monóxido de carbono, emitidos durante a queimada, e ao dióxido de carbono $\left(\mathrm{CO}_{2}\right)$, emitido pelo uso de diesel nos equipamentos agrícolas, nos ônibus e nos caminhões, visto que o $\mathrm{CO}_{2}$ emitido pela queimada não é contabilizado.

\section{POTENCIAL DE FORMAÇÃO DE OZÔNIO TROPOSFÉRICO}

De acordo com a tabela abaixo, a atividade de maior potencial para a formação de ozônio é a atividade 4 (colheita de cana). Isso se deve, principalmente, aos hidrocarbonetos, $\mathrm{NO}_{2}$ e $\mathrm{NO}_{\mathrm{x}}$ emitidos durante a queimada da cana.

Tabela 4.11. - Potencial de formação de ozônio troposférico. Fonte: (Ometto, 2005)

\begin{tabular}{|c|c|}
\hline Atividade & $\begin{array}{l}\text { Potencial de formação de } \\
\text { ozônio troposférico } \\
\operatorname{kg~C} \mathrm{C}_{2} \mathrm{O}_{4 \mathrm{eq}} / \mathbf{t}_{\text {álcool }}\end{array}$ \\
\hline 1 & 0,001 \\
\hline 2 & 0,002 \\
\hline 3 & 0,004 \\
\hline 4 & 42,547 \\
\hline 5 & 0,00 \\
\hline 6 & 0,02 \\
\hline 7 & 0,001 \\
\hline 8 & 0,001 \\
\hline 9 & 15,32 \\
\hline Total & 57,90 \\
\hline
\end{tabular}

\section{POTENCIAL DE ACIDIFICAÇÃO}

De acordo com a tabela abaixo, a atividade 4 (colheita de cana) é a de maior potencial de impacto para a acidificação. Isso se deve, principalmente, aos óxidos de nitrogênio $\left(\mathrm{NO}_{\mathrm{x}}\right)$ emitidos durante a queimada da cana. Em seguida surge a atividade 6 que corresponde a geração de energia (térmica / elétrica) com a queima do bagaço em caldeira. 
Tabela 4.12. - Potencial de acidificação. Fonte: (Ometto, 2005)

\begin{tabular}{cr}
\hline & \multicolumn{2}{c}{\begin{tabular}{c} 
Potencial de \\
Atividade \\
acidificação kg SO $_{2 \text { eq }}$ \\
/ tálcool \\
\hline 1
\end{tabular}} \\
\hline 2 & 0,02 \\
3 & 0,01 \\
4 & 0,06 \\
5 & 7,97 \\
6 & 0,00 \\
7 & 1,04 \\
8 & 0,01 \\
9 & 0,01 \\
Total & 7,63 \\
\hline
\end{tabular}

\section{POTENCIAL DE EUTROFIZAÇÃO}

Tabela 4.13. - Potencial de eutrofização. Fonte: (Ometto, 2005)

\begin{tabular}{|c|c|c|c|}
\hline \multirow[b]{2}{*}{ Atividade } & \multicolumn{3}{|c|}{ Potencial de Eutrofização } \\
\hline & $\begin{array}{c}\mathrm{N} \\
\mathrm{kg} \mathrm{N} / \mathbf{t}_{\text {álcool }}\end{array}$ & $\begin{array}{c}P \\
\operatorname{kg~} \mathbf{P} / \mathbf{t}_{\text {álcool }}\end{array}$ & $\begin{array}{l}\text { Sinergia N e P } \\
\mathrm{kg} \mathrm{NO}_{3}^{-} \text {eq } / t_{\text {álcool }}\end{array}$ \\
\hline 1 & 0,006 & 0 & 0,027 \\
\hline 2 & 5,376 & 1,68 & 77,73316 \\
\hline 3 & 10,088 & 40,4 & $1.338,71$ \\
\hline 4 & 0,004 & 0 & 0,00003 \\
\hline 5 & 0,128 & 0 & 0,56704 \\
\hline 6 & 0,446 & 0 & 2,00477 \\
\hline 7 & 5,496 & 4,95 & 182,89578 \\
\hline 8 & 0 & 0 & 0 \\
\hline 9 & 0 & 0 & 0 \\
\hline Total & 21,544 & 47,03 & 1601,93658 \\
\hline
\end{tabular}

Pela tabela acima, observa-se que as atividades que mais podem contribuir para a eutrofização são as atividades que incorporam nutrientes ao solo, se destacando as atividades 3 (tratos culturais), 7 (fertirrigação) e 2 (plantio). 


\section{POTENCIAL DE ECOTOXICIDADE}

De acordo com a tabela abaixo, a ecotoxicidade hídrica pode ser causada, principalmente, pelas atividades 1 (preparo do solo) e 3 (tratos culturais), devido ao uso intensivo de agrotóxicos no solo, que apresentam a possibilidade de percolação ou lixiviação para os recursos hídricos. A ecotoxicidade crônica do solo pode ser causada, principalmente, pelas atividades 3 (tratos culturais), 2 (plantio da cana-de-açúcar) e 1 (preparo do solo), devido ao uso intensivo de agrotóxicos aplicados diretamente no solo.

Tabela 4.14. - Potencial de ecotoxicidade. Fonte: (Ometto, 2005)

\begin{tabular}{|c|c|c|}
\hline \multirow[b]{2}{*}{ Atividade } & \multicolumn{2}{|c|}{ Potencial de Ecotoxicidade } \\
\hline & $\begin{array}{c}\text { Crônica }{ }^{45} \text { água } \\
\mathbf{m}^{3} / \mathbf{t}_{\text {álcool }}\end{array}$ & $\begin{array}{c}\text { Crônica no solo } \\
\mathrm{m}^{3} / \mathbf{t}_{\text {álcool }}\end{array}$ \\
\hline 1 & $1.286,73$ & $13.749,15$ \\
\hline 2 & 0,73 & $1.664 .131,50$ \\
\hline 3 & 772,34 & $5.589 .678,38$ \\
\hline 4 & 72,01 & 165,02 \\
\hline 5 & 0 & 0 \\
\hline 6 & 0 & 0 \\
\hline 7 & 0 & 0 \\
\hline 8 & 0 & 0 \\
\hline 9 & 0 & 0 \\
\hline Total & $2.131,81$ & 7.267.724,06 \\
\hline
\end{tabular}

\section{POTENCIAL DE TOXICIDADE HUMANA}

A tabela abaixo apresenta os resultados dos potenciais de toxicidade humana das atividades do ciclo de vida considerado, sendo a via aérea a de maior contribuição, devido, principalmente, à atividade 4 (colheita de cana), pelos gases tóxicos emitidos na queimada da cana, incluindo o material particulado emitido, e pelo uso de diesel nos caminhões, nas máquinas agrícolas e nos ônibus. Do mesmo modo, a atividade 6 relacionada com geração de vapor e eletricidade apresenta o segundo maior potencial de toxicidade devido à queima do bagaço nas caldeiras.

\footnotetext{
${ }^{45}$ Toxicidade aguda ou crônica estão relacionadas com o tempo que os efeitos diretos dos químicos levam para causar toxicidade, podendo ter duração curta (agudo) ou longa (crônica).
} 
Tabela 4.15. - Potencial de toxicidade humana. Fonte: (Ometto, 2005)

\begin{tabular}{|c|c|c|c|}
\hline \multirow[b]{2}{*}{ Atividade } & \multicolumn{3}{|c|}{ Potencial de Toxicidade Humana } \\
\hline & $\begin{array}{c}\text { Via aérea } \\
\mathbf{m}^{3} \text { ar } / \mathbf{t}_{\text {álcool }}\end{array}$ & $\begin{array}{c}\text { Via hídrica } \\
\text { m }^{3} \text { água / } / \mathbf{t}_{\text {álcool }}\end{array}$ & $\begin{array}{l}\text { Via terrestre } \\
\mathbf{m}^{3} \text { solo / } / \mathbf{t}_{\text {alcool }}\end{array}$ \\
\hline 1 & $165.616,65$ & 0,7 & 0,01 \\
\hline 2 & $459.260,26$ & 0,22 & 0,00 \\
\hline 3 & $459.769,30$ & 0,58 & 0,02 \\
\hline 4 & $1.258 .456 .278,73$ & 27,35 & 12,7625 \\
\hline 5 & 0 & 0 & 0 \\
\hline 6 & $71.869 .039,00$ & 0 & 0 \\
\hline 7 & $124.772,57$ & 0 & 0 \\
\hline 8 & $88.614,25$ & 0 & 0 \\
\hline 9 & $249.780 .000,00$ & 0 & 0 \\
\hline Total & $1.581 .403 .350,77$ & 28,85 & 12,79 \\
\hline
\end{tabular}

\subsubsection{RESULTADOS - MÉTODO EXERGIA}

A avaliação e a quantificação da queimada são realizadas com base na Exergia do combustível, palha da cana-de-açúcar, que incorpora, além da Exergia química, a física.

Comparando-se os resultados encontrados em emissões pelo método EDIP com o encontrado no cálculo das perdas por exergia das emissões atmosféricas, se observa que no primeiro caso, as substâncias $\mathrm{CO}_{2}, \mathrm{CO}$ e hidrocarbonetos eram as mais representativas, no entanto sob a ótica da exergia o $\mathrm{CO}, \mathrm{CO}_{2}$ e $\mathrm{HC}$ nesta ordem estão relacionadas com as maiores perdas no ciclo produtivo. Isso mostra que o $\mathrm{CO}$ se apresenta no ambiente de referência-padrão em concentrações bem inferiores às do $\mathrm{CO}_{2} \mathrm{e}$, embora emitidas em quantidades menores, o trabalho para equilibrar o CO na concentração de referência do ambiente é superior. Por fim, a atividade de colheita de cana-de-açúcar é a atividade de maior perda exergética, com relação às emissões atmosféricas, por causa da queimada, do uso de combustíveis fósseis dos ônibus que transportam os trabalhadores do corte da cana, dos caminhões para o transporte da canade-açúcar e dos tratores.

A exergia total do ciclo de vida do álcool é de $30,51.10^{6} \mathrm{~kJ}$. Contudo, as perdas exergéticas das emissões atmosféricas do ciclo e da queimada são igual a 40,55 $10^{6} \mathrm{~kJ}$, resultando em uma perda de Exergia de 10,04 $10^{6} \mathrm{~kJ}$ ou em, aproximadamente, $33 \%$ a mais do total, o que significa uma perda na ordem de $1 / 3$ do trabalho útil mecânico previsto. 
Assim, para cada hectare de cana queimada, há uma perda de Exergia, ou seja, de trabalho útil, correspondente a 8.701 litros de álcool por hectare. Assim, a valoração do impacto físicoquímico direto da queimada é de 8.701 litros de álcool por hectare queimado.

$\mathrm{Na}$ escala espacial do Brasil, a quantidade de palha queimada anualmente, segundo a FIESP (2001), é de 48,3 milhões de toneladas, o que resulta na perda exergética anual de 989,4 10 12 kJ no País, ou sema, em termos exergéticos, o equivalente a aproximadamente 42 bilhões de litros de álcool (Ometto, 2005).

\subsubsection{RESULTADOS - MÉTODO EMERGIA}

O método emergético, o qual, segundo Odum (1996), se baseia na quantidade de energia solar equivalente utilizada pelos insumos, equipamentos, edificações e pelos serviços para a formação do produto, pode ser aplicado à avaliação e à valoração ambiental no que se refere ao uso ou ao consumo de recursos.

Observou-se que o maior consumo emergético do ciclo de vida do álcool é devido aos materiais, principalmente para a produção do automóvel e pelo uso intensivo de produtos químicos, durante a produção industrial. A grande quantidade de insumos agrícolas também influenciou a alta Emergia dos materiais. Verificou-se que, aproximadamente, $70 \%$ do consumo de energia solar equivalente do ciclo de vida do álcool ocorre durante a fase de utilização do produto, devido à grande Emergia embutida na produção do veículo. $\mathrm{O}$ alto consumo de água contribui para que a quantidade emergética dos recursos renováveis seja a segunda maior, embora bem inferior à Emergia dos materiais utilizados.

O valor da taxa de carga ambiental encontrada para o ciclo de vida estudado é de 45,23 (adimensional) considerado por Ometto (2005) extremamente alto. Tal resultado representa que a energia solar equivalente dos recursos não-renováveis e dos recursos advindos do sistema econômico são 45,23 vezes maior que e energia solar equivalente dos recursos renováveis utilizados. Isso se deve, principalmente, à grande Emergia incorporada no automóvel e nos produtos químicos utilizados, principalmente, na fase industrial.

A taxa de renovabilidade do ciclo é de $2 \%$, indicando que o álcool é intensamente dependente dos insumos não-renováveis e da economia, principalmente devido à grande Emergia incorporada no automóvel e nos produtos químicos utilizados. 
Os resultados obtidos por este método, para este estudo, não puderam absorvidos de uma forma mais completa visto que a atividade 9 possui uma grande participação nos resultados encontrados, como era de se esperar (atividades de maior hierarquia assumindo uma importância na análise emergética).

\subsection{CONCLUSAO}

Os resultados do EDIP mostram que a atividade da colheita de cana apresenta o maior potencial de impacto para o consumo de recursos renováveis, o aquecimento global, a formação fotoquímica de ozônio troposférico, a acidificação e a toxicidade humana. $\mathrm{O}$ preparo do solo apresenta maior potencial para o consumo de recursos não renováveis e para a ecotoxicidade da água. O trato cultural apresenta maior influência na eutrofização e na ecotoxicidade do solo. Pela Exergia, verifica-se que, para cada litro de álcool consumido, há uma perda de exergia pelas emissões atmosféricas de seu ciclo de vida, considerando que 25 $\%$ da cana colhida seja crua, equivalente à exergia de, aproximadamente, 1,38 litros de álcool. Portanto, a fim de adequar ambientalmente o ciclo de vida do etanol hidratado combustível, indica-se a eliminação da queimada, a redução do uso de agrotóxicos, de combustível fóssil.

A exergia aplicada às emissões mostra-se como uma medida do trabalho mecânico desperdiçado que causa impacto físico-químico direto no meio. A emergia, por sua vez, mede a quantidade de energia solar incorporada aos insumos e aos serviços pelo trabalho ecossistêmico, durante as suas formações, e apresenta uma abordagem mais ampla que a exergia, incluindo os sistemas naturais e da economia.

Assim, as avaliações pela emergia e pela exergia podem retratar, respectivamente, a eficiência ecossistêmica e a eficiência termodinâmica do ciclo de vida de um produto. Portanto, as aplicações da emergia e da exergia neste trabalho são complementares

Dentre os métodos utilizados, o EDIP mostra-se como o mais direto para a avaliação de impacto ambiental, um dos motivos que o torna um dos métodos mais utilizados em ACV. Os resultados baseados no EDIP apresentam as atividades de maiores potenciais de impacto ambiental para cada categoria. A atividade da colheita de cana é a de maior potencial de impacto para: potencial de aquecimento global, potencial de formação fotoquímica de ozônio troposférico, potencial de acidificação e potencial de toxicidade humana. A principal causa de a atividade de colheita ser a de maior potencial para estas categorias é a queimada da palha da cana-de-açúcar. 
A atividade de preparo do solo é a de maior potencial de impacto para as categorias de consumo de recursos não-renováveis e de ecotoxicidade da água. A principal causa desses altos potenciais é o uso intensivo de diesel e de agrotóxicos, respectivamente. A atividade de tratos culturais apresenta-se como a de maior potencial para as categorias de eutrofização e de ecotoxicidade do solo. Isso se deve ao uso intensivo de agroquímicos.

A atividade de processo industrial é a de maior consumo de recursos renováveis, devido, principalmente, ao alto consumo de água. Com relação aos resultados da Exergia, para cada litro de álcool, há uma perda de exergia pelas emissões atmosféricas de seu ciclo de vida que equivale à exergia de, aproximadamente, 1,38 litros de álcool. A contribuição da queimada da palha da cana-de-açúcar, frente ao total de perda exergética das emissões atmosféricas, é de, aproximadamente, 91\%, ou seja, equivalente à exergia de 1,26 litros de álcool para cada litro de álcool produzido, considerando que $25 \%$ da cana colhida seja crua. (Ometto, 2005)

Como se verifica, a eliminação da queimada traz ganhos, em termos energéticos e ambientais, além de produtivos, pela retenção da sacarose perdida pela exsudação do colmo durante a queima. 


\section{EXTERNALIDADES - CONCEITOS E MÉTODOS DE AVALIAÇÃO E QUANTIFICAÇÃO}

\subsection{ASPECTOS CONCEITUAIS}

A economia de mercado procura direcionar diversos aspectos de forma coerente, no entanto tem dificuldade para atingir uma abrangência total. A seguir, é apresentado o conceito de custos externos $^{46}$ e porque o mercado não consegue sempre alocar os recursos de forma eficiente e ampla. Também serão indicados quais são os meios de potencialmente melhorar esta alocação sem a pretensão de esgotar o assunto, mas destacar os principais conceitos, soluções e limitações que o envolvem. Um tratamento formal ao problema, incluindo o desenvolvimento matemático envolvido, é encontrado em: Sandler e Cornes, 1995; e, MasColell, Whinston e Green, 1995.

As falhas de mercado ${ }^{47}$ examinadas neste capítulo estão reunidas numa categoria conhecida como externalidades. Uma externalidade ocorre quando um agente engajado numa atividade influencia o bem-estar de agente externo que não participa da ação e que não é remunerado tão pouco onerado por esse efeito. Os efeitos sobre o agente externo podem ser classificados como:

- externalidade positiva, onde o efeito é benéfico; ou,

- externalidade negativa, onde o efeito é adverso, isto é, onera.

$\mathrm{Na}$ presença dos custos externos, o interesse da sociedade no mercado se estende além do bem-estar dos compradores e vendedores; incluindo o bem-estar dos agentes que são afetados pelas atividades. A justificativa ocorre, pois os compradores e vendedores negligenciam os efeitos externos de suas ações quando decidem a quantidade a ser demandada e oferecida sendo que o equilíbrio do mercado não é o ótimo na presença das externalidades. Isto é, no

\footnotetext{
${ }^{46}$ ou externalidades.

${ }^{47}$ outras formas de imperfeições no mercado: dificuldade na concorrência perfeita, formação grupos oligopolistas, oligopsônicas, monopolistas, monopsônias, assimetria da informação, falha de Governo etc. Tornando o preço de equilíbrio fora do ótimo social pois algum agente vai prevalecer com uma condição dominante. Em suma, maximizando o seu bem-estar ao invés de todos os agentes.
} 
equilíbrio o mercado falha ao procurar maximizar o benefício para a sociedade como um todo $^{48}$.

Dentro deste contexto, a tomada de decisão entre os agentes é falha, pois desconsidera os efeitos devidos às suas atividades. Sendo assim, o governo responde procurando influenciar esse comportamento e proteger o interesse coletivo dos agentes atingidos pelas externalidades.

\subsection{EXTERNALIDADES E A INEFICIÊNCIA DO MERCADO}

Algumas ferramentas podem ser utilizadas para examinar como as externalidades afetam a economia. A análise permite apontar como os custos externos influenciam o mercado a alocar seus recursos de forma ineficiente. Os meios de remediar esse comportamento também são apresentados mais adiante.

Para um dado mercado ${ }^{49}$ a curva de oferta contém importantes informações sobre os custos e benefícios. A curva de demanda reflete o valor do bem para o consumidor, o qual é representado pela disposição do quanto se deseja pagar pelo bem.

$\mathrm{Na}$ ausência da intervenção do governo, o preço é ajustado com o balanço entre a oferta e a demanda do bem. A quantidade produzida e consumida no equilíbrio de mercado, na ausência das externalidades, é eficiente no sentido de maximizar o excedente, como pode ser visto na figura abaixo. Em suma, o mercado alcança a eficiência econômica ${ }^{50}$.

\footnotetext{
${ }^{48}$ Ótimo social ou Ótimo de Pareto (Vilfrido Pareto, economista - 1923/1948), ponto onde o bem-estar é maximizado sendo que ninguém poderá melhorar a sua situação sem que alguém seja prejudicado. O conceito de maximização de utilidade é empregado comumente na literatura de economia.

49 ex. açúcar e álcool.

${ }^{50}$ desconsiderando, também, a presença da falha de mercado: assimetria / ausência da informação.
} 


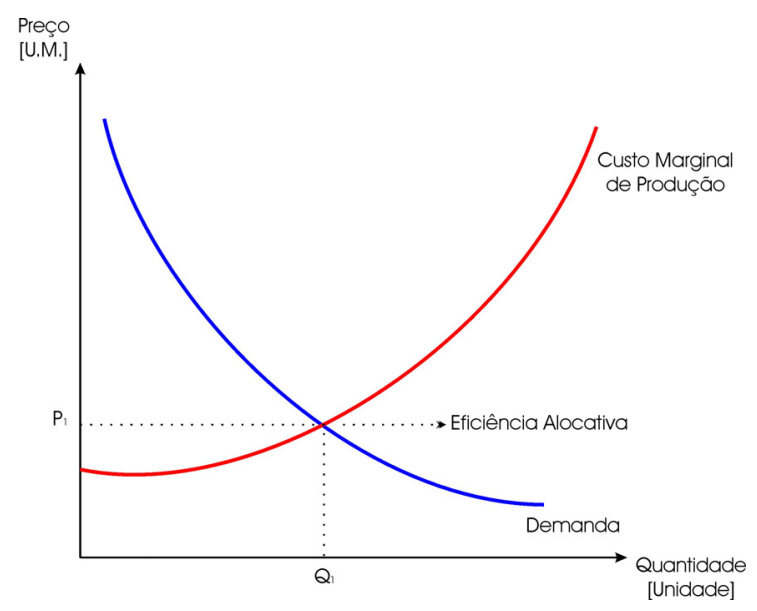

Figura 5.1. Exemplo de equilíbrio de mercado. Elaboração própria

A seguir, a presente seção procurou avaliar os custos externos tanto na produção quanto no consumo, mas é importante salientar que é possível encontrar um efeito combinado de ambos, isto é, a co-ocorrência de externalidades tanto na produção quanto no consumo. Envolvendo desde uma externalidade na sua modalidade mais simples, que abrange dois agentes sendo conhecida como bilateral ou quando vários agentes encontram-se envolvidos, conhecido como externalidades multilaterais ou em rede.

As soluções tradicionais para este tipo de problema também são apresentadas, sob a forma de taxas, definição de quotas ou padrões e soluções de mercado, como por exemplo, negociação entre os agentes.

\subsubsection{EXTERNALIDADES NA PRODUÇÃO}

Para um entendimento consistente dos custos externos na produção os conceitos de externalidades positiva e negativa são explorados.

Considere que na produção de um determinado bem, há poluição atmosférica e que tal poluição cause risco de saúde para as comunidades que estão próximas da instalação fabril, neste caso tem-se uma externalidade negativa. Por isso, o custo para a sociedade da produção desse bem é maior do que o custo do produtor. Em cada unidade há um custo marginal social incluso, isto é, além do custo marginal de produção há um custo marginal social (ou custo marginal externo) devido aos agentes afetados pela poluição. Na figura 5.2, a nova curva de 
custo marginal de produção está acima da original por considerar o aspecto social sendo que a diferença entre as duas curvas reflete o custo pela externalidade envolvida.

Considerando esse cenário, há um novo ponto de equilíbrio ${ }^{51}$ entre a nova curva de custo marginal de produção e a demanda. Devido à curva ser deslocada para um patamar superior ${ }^{52}$ a nova quantidade é inferior $\left(\mathrm{Q}_{2}\right)$ a quantidade inicial $\left(\mathrm{Q}_{1}\right)$ no equilíbrio. O fabricante não irá produzir acima do nível de equilíbrio, pois o custo marginal social embutido na produção excede a disposição dos consumidores em adquirir o bem. Tal situação encontra-se ilustrada na figura 5.2.
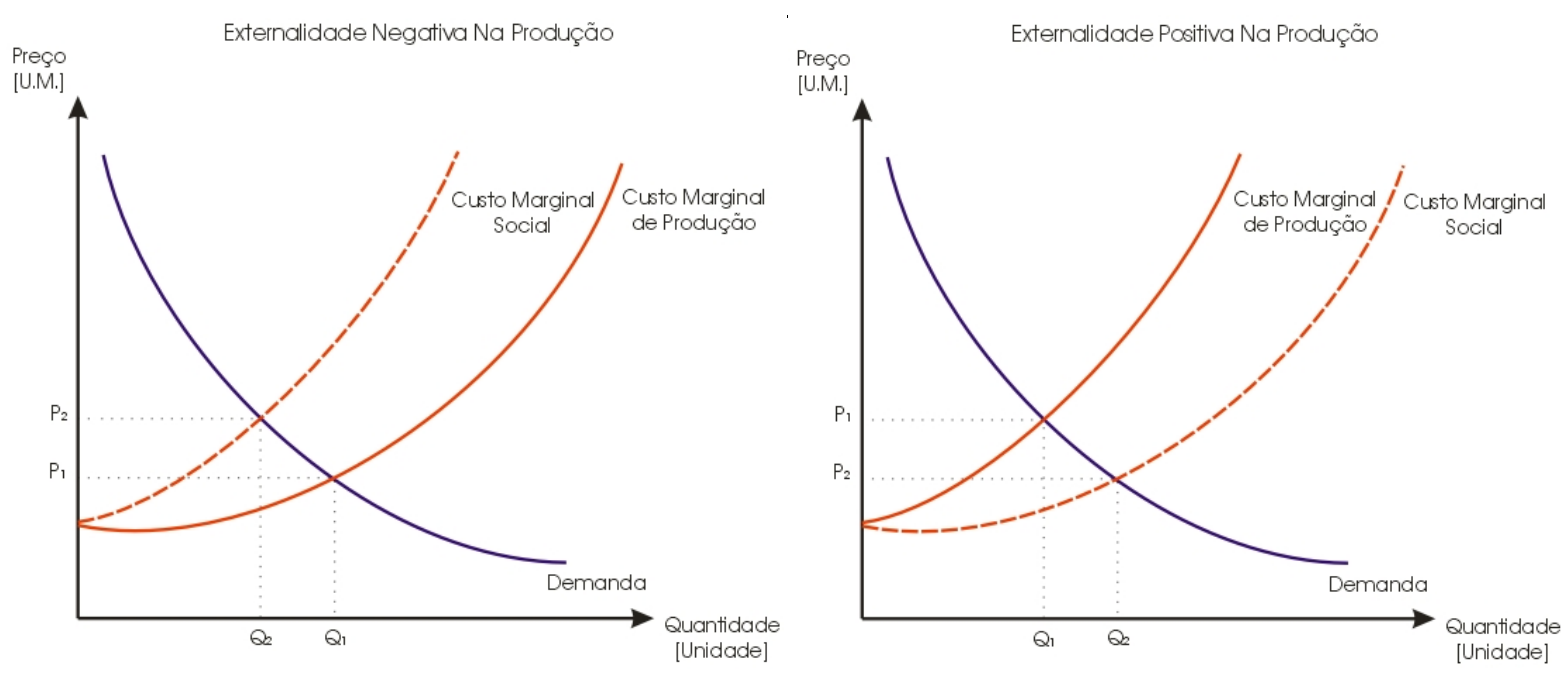

Figuras 5.2. e 5.3. Exemplo de externalidade negativa e positiva na produção, respectivamente. Elaboração própria

Uma razão para essa ineficiência é que o equilíbrio inicial do mercado apenas refletir os custos privados de produção. Se o novo ponto de equilíbrio fosse atingido, a alocação dos recursos seria eficiente.

Uma das possibilidades para reduzir a ineficiência apresentada, por exemplo, é aplicar uma taxa por quantidade ou peso do bem produzido. Se a taxa representar o custo social da poluição atmosférica, a nova curva de oferta irá coincidir com a curva onde o custo social foi considerado e então, o bem será produzido na quantidade ótima para a sociedade.

\footnotetext{
${ }^{51}$ ponto ótimo analisando sob a perspectiva da sociedade como um todo.

52 mantido os demais fatores constantes.
} 
Ferramentas como as utilizadas acima são consideradas como formas de internalização das externalidades, pois dão aos produtores e compradores o sinal econômico que considera a relação dos efeitos externos de suas atividades.

A segunda possibilidade é a avaliação da externalidade positiva na produção, onde o custo social é inferior ao privado $^{53}$. O que implica numa produção em quantidade superior à necessária no mercado privado, estando no equilíbrio, conforme a figura 5.3 exemplifica.

Neste caso, um possível meio de internalizar o benefício da externalidade é subsidiar a produção de um bem de modo a se atingir o nível de produção ótimo social. Em suma, é aplicar um subsidio proporcional a externalidade positiva.

\subsubsection{EXTERNALIDADES NO CONSUMO}

A análise das externalidades no consumo é similar à análise das externalidades na produção.
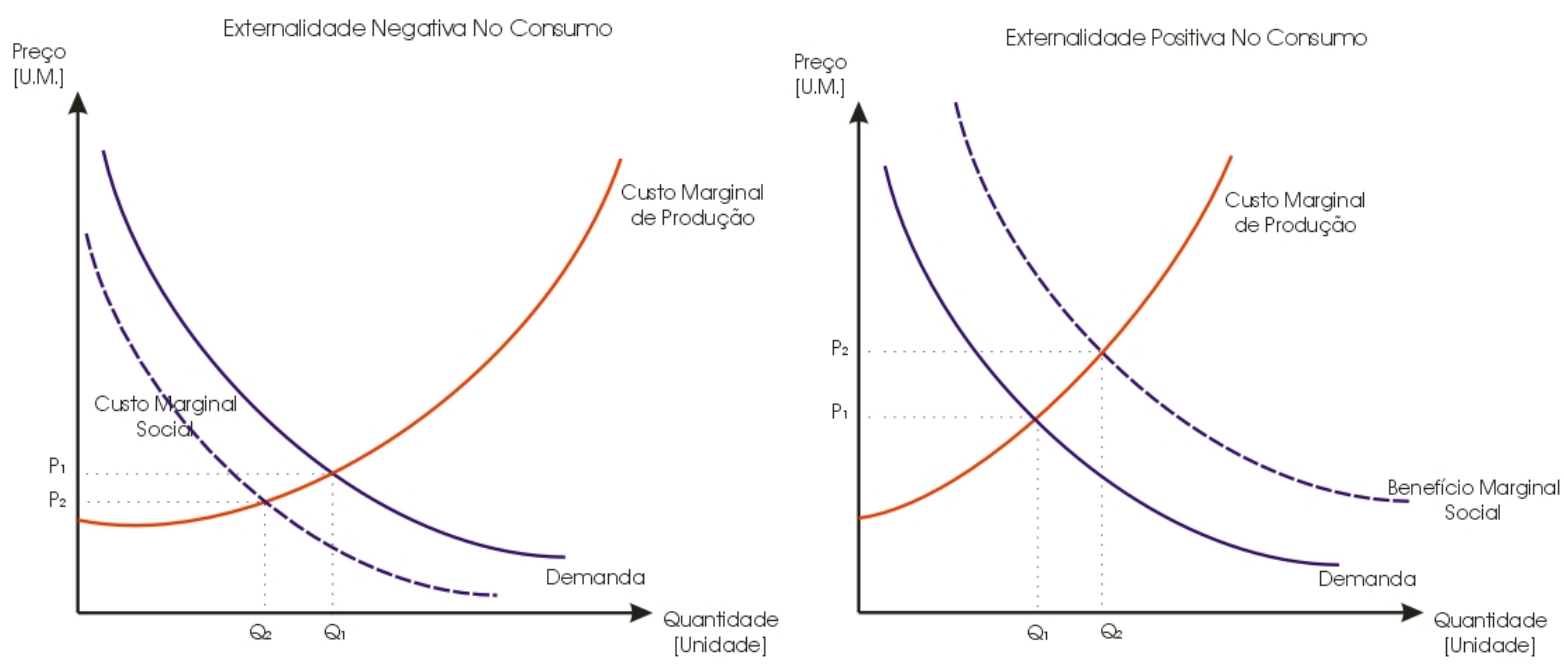

Figuras 5.4. e 5.5. Exemplo de externalidade negativa e positiva no consumo, respectivamente. Elaboração própria

Uma externalidade negativa no consumo implica num valor social inferior do que o privado e o ótimo social também em quantidade inferior como pode ser visto na figura 5.4 com os valores de $\mathrm{Q}_{1}$ e $\mathrm{Q}_{2}$. E a externalidade positiva no consumo possui um valor social superior ao de mercado e, o ótimo social também em quantidade superior ao determinado pelo mercado

\footnotetext{
${ }^{53}$ pois é o custo de produção privado descontado o benefício da externalidade
} 
privado, representado pela figura 5.5. Um tratamento mais detalhado será apresentado mais adiante.

Do mesmo modo, o governo pode interferir procurando corrigir essa falha de mercado induzindo os agentes participantes a internalizar os custos externos. Inclusive, por exemplo, utilizando a mesma ferramenta usada na externalidade de produção: aplicando taxas aos custos externos negativos e subsídios nos positivos, procura-se atingir o ótimo social.

Da discussão sobre a externalidade positiva ou negativa, ocorrendo seja no consumo ou na produção, alguns itens devem ser ressaltados:

- externalidades negativas induzem o mercado a produzir quantidades superiores ao socialmente desejável. Uma possibilidade de remediação dessa ineficiência alocativa é a internalização da externalidade aplicando taxas ao bem; e,

- externalidades positivas induzem o mercado a produzir quantidades inferiores ao ótimo social. Uma opção de remediação dessa ineficiência alocativa é a internalização da externalidade aplicando subsídios ou outras formas de incentivo ao bem.

As externalidades geram no curto e longo prazo a ineficiência alocativa. Por exemplo, sabe-se que uma firma entra numa determinada atividade com competitividade sempre que o preço do produto estiver superior ao custo médio de produção, e sai do mercado quando o preço atinge níveis menores que custo médio de produção. No longo prazo ${ }^{54}$ o preço é igual ao custo médio. Quando há uma externalidade negativa, o custo médio privado de produção é menor que o custo médio social o que resulta em firmas permanecendo em determinada atividade mesmo sendo mais eficiente ausentar-se do mercado.

\subsection{SOLUÇÕES PRIVADAS PARA EXTERNALIDADES}

As externalidades levam o mercado a alocar os recursos de forma ineficiente; alguns exemplos de opções de remediação foram mencionados. Na prática, tanto os atores privados quanto os públicos responsáveis pela elaboração de políticas respondem as externalidades de

\footnotetext{
${ }^{54}$ isto é, no equilíbrio.
} 
diferentes modos. Contudo, as remediações dividem um objetivo comum: mover a alocação dos recursos ao ótimo social. Nesta seção tratar-se-á das soluções privadas.

\subsubsection{TIPOS DE SOLUÇÕES PRIVADAS}

Mesmo com a tendência das externalidades induzirem o mercado à ineficiência, a ação do governo não é sempre necessária para a solução do problema. Em algumas circunstâncias, as soluções privadas podem corrigir as falhas existentes.

É comum no mercado privado a solução de um problema de externalidades baseado no interesse mútuo dos agentes. A solução pode ter o formato de integração de diferentes tipos de negócios. A internalização das externalidades é um possível motivo para que algumas firmas estejam envolvidas com diferentes tipos de empreendimentos.

Outra maneira com o que o mercado privado lida com os efeitos externos é através de contratos entre as partes interessadas com possibilidade de transferência de capital procurando encontrar um ótimo alocativo.

\subsubsection{O TEOREMA DE COASE}

O Teorema de Coase $^{55}$ propõe que, se as partes privadas puderem barganhar sem custo de alocação dos recursos, então o mercado privado irá sempre resolver o problema das externalidades e alocar os recursos de forma eficiente. Seja qual for a distribuição inicial dos direitos, as partes interessadas podem sempre alcançar uma barganha na qual os envolvidos estejam numa situação melhor e a alocação atinja maior eficiência.

\subsubsection{PORQUE SOLUÇÕES PRIVADAS NÃO FUNCIONAM SEMPRE}

Apesar do Teorema de Coase, os atores privados normalmente falham em resolver problemas causados pelas externalidades. Ele se aplica apenas quando as partes interessadas não possuem nenhum empecilho em alcançar e executar o acordo. No mundo real, entretanto,

\footnotetext{
${ }^{55}$ Robert Coase, The Problem of Social Cost, Journal of Law and Economics, Vol. 3, pg 1-44, 1960.
} 
acordos não funcionam sempre, mesmo quando há possibilidade de um benefício mútuo conhecido.

$\mathrm{Na}$ grande parte dos casos, as partes interessadas falham em resolver um problema de externalidade por causa dos custos de transação envolvidos, isto é, custos que as partes deverão incorrer no processo de acordo ou barganha. Em especial, acordos são de difíceis implementações, principalmente quando o número de partes interessadas é grande pelos custos envolvidos em coordenar cada um deles. $\mathrm{O}$ fato de nem todos os agentes envolvidos conhecerem as necessidades um dos outros dificulta a escolha do agente adequado para um processo de acordo.

\subsection{POLÍTICAS PÚBLICAS E AS EXTERNALIDADES}

Quando uma externalidade aponta uma alocação ineficiente dos recursos do mercado, o Governo pode responder com uma das seguintes formas de políticas:

- de comando e controle ${ }^{56}$, onde a atuação é feita de forma direta visando regular a atividade; ou,

- baseadas no mercado, onde se aplica um sinal econômico permitindo que o mercado privado resolva o problema por sua conta, sendo vista como uma forma menos intrusiva.

Em todos os casos, o governo deve conhecer os detalhes específicos dos setores industriais e das tecnologias alternativas para subsidiar sua opção.

\subsubsection{POLÍTICAS DE COMANDO E CONTROLE}

\section{REGULAÇÃO}

Esta atividade vista ditar o comportamento dos agentes ou sinalizar economicamente induzindo assim, o que se espera como ação. A regulação de uma atividade ou até mesmo de

\footnotetext{
${ }^{56}$ Políticas de comando e controle existem na maioria das economias no mundo. A dificuldade na sua utilização reside na definição dos custos de controle, devido a incerteza na estimativa correta dos custos externos.
} 
um mercado pode ocorrer como definição de uma tecnologia específica ou até mesmo firmando patamares máximos, médios e mínimos a serem controlados e supervisionados pelo Estado. Por exemplo, a fixação de padrões de máximos primários e secundários referentes à qualidade do ar estabelecida via RESOLUÇÃO CONAMA No 3/1990 e 382/2006.

\section{TAXAS PIGOUVIANAS E SUBSÍDIOS}

O Governo pode utilizar políticas baseadas no mercado para alinhar os incentivos privados com a eficiência social. Como foi apresentado anteriormente, o governo pode internalizar uma externalidade taxando atividades que tenham efeitos negativos ou subsidiando as que possuem efeitos positivos. Taxas aplicadas para corrigir efeitos negativos das externalidades são conhecidas como taxas pigouvianas ${ }^{57}$.

Em suma, a regulação procura ditar um nível de impactos enquanto que o emprego de taxas procura inserir um incentivo econômico nos setores envolvidos para redução dos efeitos externos. Por exemplo, enquanto uma ação de regulação pode reduzir a emissão de determinado poluente numa quantidade determinada por ano, há a possibilidade da aplicação de uma taxa para cada tonelada emitida de um composto específico.

Na opinião de Mankiw (2003) a aplicação de taxas é mais eficaz que a regulação. A principal razão reside no fato da regulação requerer que cada atividade reduza a mesma quantidade de um determinado item, mas uma redução idêntica não é necessariamente a de menor custo, pois diferentes setores podem remediar com custos diferentes uma mesma externalidade.

A taxa estimula o agente a agir de modo a reduzir ainda mais o impacto, desde que definida adequadamente. Esta premissa é de suma importância tendo com principal obstáculo a ausência / assimetria da informação no momento de se firmar a taxa. Se esta é estabelecida com padrões baixos permite que o agente atue com excesso, por outro lado, uma taxa rígida demais, pode restringir em demasia a atividade produtiva além do controle desejado, gerando um ônus extra. Destacam-se, ainda, outras opções para o emprego de taxas, tais como: fixas ou progressivas de acordo com o dano causado pela atividade.

\footnotetext{
${ }^{57}$ Pigout, A. C., The Economic of Welfare (1932)
} 
Em essência, a taxa pigouviana dá lugar a um preço pelo direito de causar o efeito externo. Assim como o mercado aloca os bens para os consumidores que os valorizam da melhor forma, as taxas pigouvianas alocam os impactos pelas atividades que encontram os maiores custos para reduzi-los. Independente do nível determinado, o custo total deve ser minimizado quando há o emprego da taxação, pois sobre a política de comando e controle as atividades poluidoras não têm razão para reduzir os impactos caso tenham cumprido a meta de redução dos mesmos. Em contraste, o emprego das taxas pode representar um incentivo para o desenvolvimento e emprego de tecnologias mais eficientes reduzindo assim o montante pago em taxa por determinada atividade.

Taxas pigouvianas são diferentes de outros tipos de taxas, pois estas últimas, em geral, distorcem os incentivos e movem a alocação dos recursos no sentido oposto do ótimo social. A redução do bem-estar econômico, isto é, o excedente do consumo e oferta supera a quantidade de arrecadação do Governo, resultando numa perda. Em contraste, quando as externalidades estão presentes, a sociedade se importa com bem-estar dos que foram afetados pela atividade. Deste modo, a taxa pigouviana corrige os incentivos na presença das externalidades e move a alocação de recursos no sentido do ótimo social. Deste modo, a taxa pigouviana aumenta a receita para o Governo e melhora a eficiência econômica.

\subsubsection{POLÍTICAS BASEADAS NO MERCADO}

\section{COMERCIALIZAÇÃO DAS PERMISSÕES}

Considere duas indústrias de segmentos distintos quaisquer A e B. A indústria B deseja aumentar a sua produção sendo que está no limite de emissões permitido. Porém a indústria A tem capacidade de reduzir suas emissões na mesma proporção que a indústria $\mathrm{B}$ necessita. Se houver acordo entre as partes, a indústria $\mathrm{B}$ pode pagar para $\mathrm{A}$ reduzir as suas emissões ${ }^{58}$.

Do ponto de vista da eficiência econômica, esta forma de transação é interessante, pois ambos estão de acordo voluntariamente ${ }^{59}$ não havendo efeitos externos já que a quantidade de poluição é a mesma e do ponto de vista do bem-estar econômico, a alocação é feita de uma maneira mais eficiente.

\footnotetext{
${ }^{58}$ exemplo ilustrativo, desconsiderando demais fatores legais e fontes de tomada de decisão.

${ }^{59}$ Teorema de Coase
} 
Existe também a possibilidade de transacionamento do direito de poluir de uma firma para a outra. Percebe-se que há a formação de um mercado de intercâmbio dessas permissões de poluição e que pode se tornar um mercado governado pelas forças da oferta e demanda.

A vantagem de um mercado de permissões é que a alocação inicial delas entre as firmas independe do ponto de vista da eficiência econômica. A lógica por trás dessa conclusão é a mesma do Teorema de Coase. As firmas que puderem reduzir seus efeitos facilmente irão manifestar o interesse de conseguir o máximo de permissões possíveis, enquanto que as atividades que têm um alto custo para reduzir os impactos estarão dispostas a adquiri-las e, portanto, a alocação será eficiente independente da condição inicial.

Mesmo assim, para o exemplo apresentado, a redução da poluição utilizando permissões pode parecer diferente do uso de taxas pigouvianas, porém as duas políticas têm muito em comum. Por exemplo, para as duas possibilidades de remediação a firma paga pela sua poluição. Sendo que pelas taxas pigouvianas, a firma paga para o Governo a taxa e com as permissões de poluição as firmas poluidoras precisam pagar pelas permissões de outras firmas. O custo de oportunidade de poluir é o que eles estão recebendo por vender suas permissões num mercado aberto. Além de ambas serem meios de internalização da externalidade relacionada com a poluição tornando custoso para as firmas o ato de poluir.
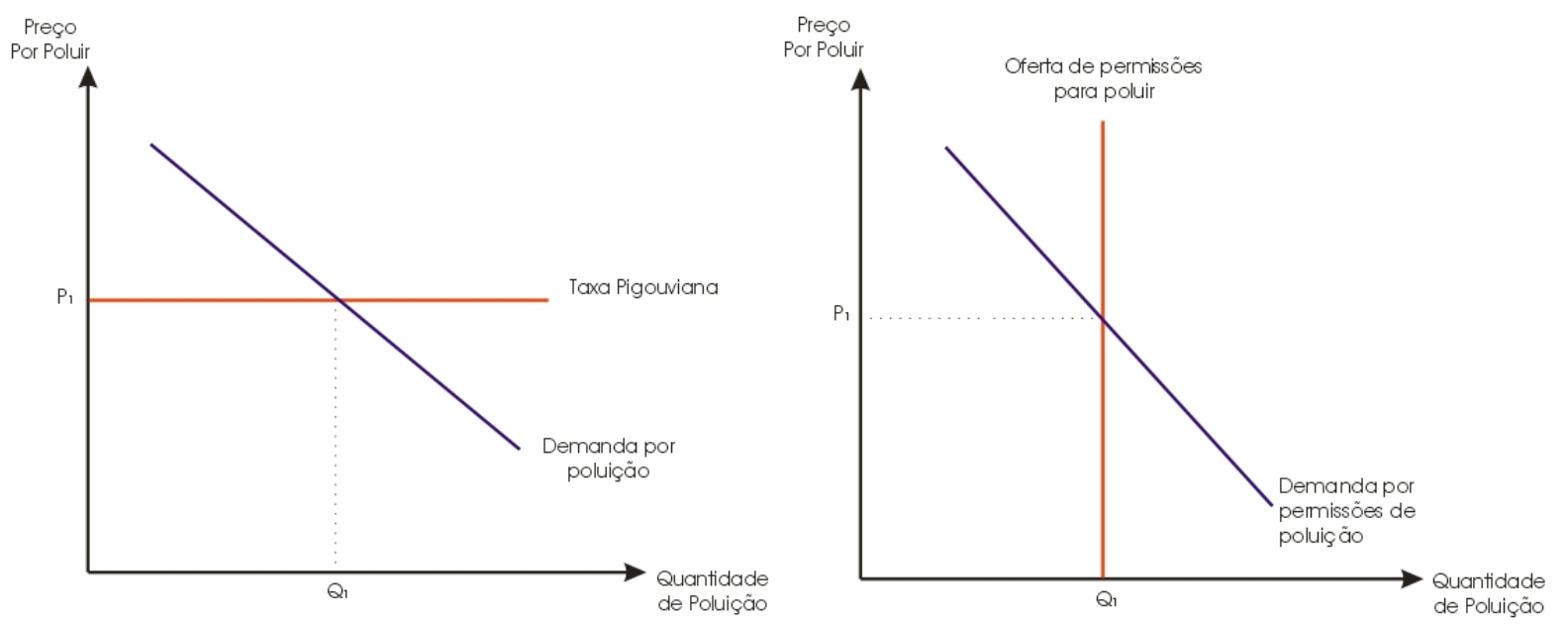

Figuras 5.6. e 5.7. Exemplo de taxa pigouviana e comercialização de permissões, respectivamente.

A similaridade entre as duas políticas pode ser vista nas curvas acima. Na Figura 5.6., a curva de demanda para o direito de poluir mostra que quanto menor for o preço, mais firmas vão optar por poluir. Ainda, há a utilização da taxa pigouviana para fixar o preço para poluição. 
Neste caso a curva de oferta para o direito de poluir é perfeitamente elástica ${ }^{60}$ e a posição da curva de demanda determina a quantidade.

Na Figura 5.7., há a utilização das permissões de poluição sendo que neste caso a curva de oferta é perfeitamente inelástica ${ }^{61}$ e a posição da curva de demanda determina o preço da poluição.

Em algumas circunstâncias, contudo, a venda de permissões pode atingir resultados melhores ao das taxas pigouvianas. Caso haja o interesse de limitar uma quantidade de poluente numa dada área havendo o desconhecimento da curva de demanda para poluição, há uma incerteza do valor da taxa para atingir tal meta. Neste caso, um leilão das permissões de poluição irá apontar a disposição das firmas para adquirir as permissões tornando-se um instrumento mais apropriado que a taxa pigouviana.

Entretanto, podem existir externalidades que estejam intrinsecamente desassociadas de competitividade num mercado deste tipo, como por exemplo, a diminuição da expectativa de vida devida à exposição de algum efeito externo de uma atividade econômica.

\subsubsection{VANTAGENS E DESVANTAGENS DAS POLÍticAS PÚBLICAS NAS EXTERNALIDADES}

Sobre o assunto, alguns argumentos destacados em Bolognini (1996) e expostos na literatura específica, serão apresentados:

- os impostos representam a via de menor custo para mudanças no comportamento econômico dos agentes;

- taxas pigouvianas e a política de comando e controle apresentam aspectos distributivos com alvo em grupos de agentes distintos, pois as taxas internalizam custos externos para os agentes que antes não consideravam os seus impactos externos enquanto que a regulação atinge a todos de forma igual necessitando de regras e padrões a serem seguidos;

\footnotetext{
${ }^{60}$ as firmas podem poluir o quanto elas estão dispostas a pagar de taxa.

${ }^{61}$ a quantidade de poluição é fixa pelo número de permissões.
} 
- políticas de comando e controle tendem, pelo aparato institucional envolvido, a ser um processo mais lento e oneroso além das dificuldades frente à diversidade de processos, atividades e etc.;

- a regulação exige um levantamento de informações dos impactos que os custos externos ocasionam para que as medidas adotadas possam efetivamente dar o sinal econômico preciso para o mercado. De outra forma, haverá perdas no processo e a remediação estará comprometida; e,

- como foi dito anteriormente, taxas pigouvianas permitem que o mercado procure a solução com o menor custo além de incentivar tecnologias de menor impacto.

Permissões legais podem criar um mercado relacionado com as externalidades. Tal mercado é tentador, pois combina algumas vantagens do sistema de regulação com as vantagens em relação aos custos do sistema de taxas pigouvianas. Uma agência pode administrar o número total de permissões como o sistema de regulação deveria fazer. Mas a comercialização possibilita um nível de abatimento da poluição a ser atingida ao mínimo custo como no sistema de $\operatorname{taxas}^{62}$.

\subsubsection{CONCLUSÕES}

Por fim, quando as informações são incompletas a regulação oferece maior certeza quanto aos níveis/padrões a serem adotados, mas deixa os custos para abatimento incertos. Taxas pigouvianas por sua vez, oferecem a certeza dos custos de abatimento, mas deixam os níveis/padrões incertos. E quanto às políticas com base no mercado, elas demandam que os agentes conheçam as suas preferências entre si, o que não é usual.

Conclui-se que a determinação da melhor política depende, conseqüentemente, da natureza da incerteza, do comportamento das curvas de custo para o setor em questão (Pindyck, 2002) e da disponibilidade/qualidade das informações para caracterizar o custo externo.

\footnotetext{
${ }^{62}$ se houver limitações nas informações e elevados custos para o monitoramento, o sistema de comercialização de permissões não é o ideal. Por exemplo, se os custos de abatimento forem muito elevados, algumas firmas sairão prejudicadas tornando-se um problema para o emprego das taxas pigouvianas.
} 


\subsection{COMPLEMENTADO OS ASPECTOS CONCEITUAIS}

As externalidades, anteriormente foram categorizadas sob os aspectos dos seus efeitos / impactos como positivas ou negativas. Contudo, elas podem ser categorizadas, também, sobre os seguintes aspectos ${ }^{63}$ :

- privadas, quando a externalidade se incrementada em uma unidade para um único indivíduo, será refletida como uma unidade a menos a ser vivenciada pelos demais agentes que sofrem o efeito externo; ou,

- públicas, quando a externalidade que afeta um agente, atinge da mesma forma os demais agentes que a vivenciam. Esta característica está correlacionada com a presença de bens públicos.

Para as externalidades ditas privadas, a referência (Mas-Colell, Whinston et Green, 1995) demonstra que se espera das soluções de mercado, níveis ótimos de alocação para as externalidades tanto na produção quanto no consumo.

Para as externalidades ditas públicas, a referência (Mas-Colell, Whinston et Green, 1995) demonstra que se espera do governo ações que visem atingir níveis ótimos de alocação com a utilização da regulação e o emprego de taxas se, e somente se, ele tenha as informações adequadas e completas para guiar suas decisões. Outra solução apresentada é estabelecer uma quota máxima para a externalidades e distribuí-las para comercialização das permissões. Também neste caso a qualidade das informações é de fundamental importância para definição da quota inicial. Entretanto, para a utilização da comercialização das permissões o volume de informações pode ser limitado em relação às informações necessárias ao emprego da regulação e taxas.

Ainda se tratando de outras distinções existentes na literatura sobre externalidades, principalmente as que abrangem um conjunto de agentes envolvidos, as externalidades podem ser:

- alocáveis, isto é, dependendo das condições num determinado instante $t$ devido a outros fatores, os agentes que vivenciam a externalidade são diferentes. Um exemplo é

\footnotetext{
${ }^{63}$ quando se consideram vários agentes estão envolvidos.
} 
a chuva ácida que, dependendo das condições meteorológicas da região poderá atingir diferentes áreas; ou,

- não-alocáveis, não dependem de outros fatores externos para atingir um determinado agente exposto à externalidade.

Por fim, duas outras possíveis abordagens para a questão das externalidades são apresentadas a seguir, não sendo detalhadas, por apresentarem limitações quanto à aplicação na prática, são elas:

- o equilíbrio de Lindahl ${ }^{64}$, diretamente ligado ao uso dos bens públicos e relacionado às externalidades quando classificadas como sendo públicas; e,

- o mecanismo de Groves-Clarke ${ }^{65}$, este mecanismo consegue atingir níveis ótimos na alocação das externalidades, mas depende da veracidade e qualidade das informações apresentadas e possui um entrave pois gera um ônus para o Estando originando outra forma de ineficiência para suplantar este ônus.

\subsection{METODOS DE AVALIAÇÃO E QUANTIFICAÇÃO DAS EXTERNALIDADES NO SETOR ELÉTRICO}

O principal objetivo desta seção é apresentar as técnicas de avaliação e quantificação de externalidades apresentando os métodos desenvolvidos abrangendo desde questões conceituais até exemplos práticos realizados na área. O foco desta seção são as externalidades que envolvem a geração de energia elétrica.

A princípio, a primeira figura que se deve ter em mente é o custo total social sendo este composto pelo custo externo e privado bem como a sua forma de internalização e a categorização de como os efeitos estão distribuídos. Estes blocos estão relacionados conforme

\footnotetext{
${ }^{64}$ Maiores informações em: Lindahl, E., Just taxation - a positive solution. Em Classics in the Theory of Public Finance. / Milleron, J. C., Theory of value with public goods: A survey article. Journal of Economic Theory 5: 419-77.

${ }^{65}$ Maiores informações em: Clarke E.H., Multipart pricing of public goods. Journal of Law and Economics 1: 144. / Groves, T. Incentives in teams. Econometrica 41: 617-31.
} 
o diagrama apresentado na figura 5.8. sendo o bloco do custo externo, o de principal interesse nesta seção.

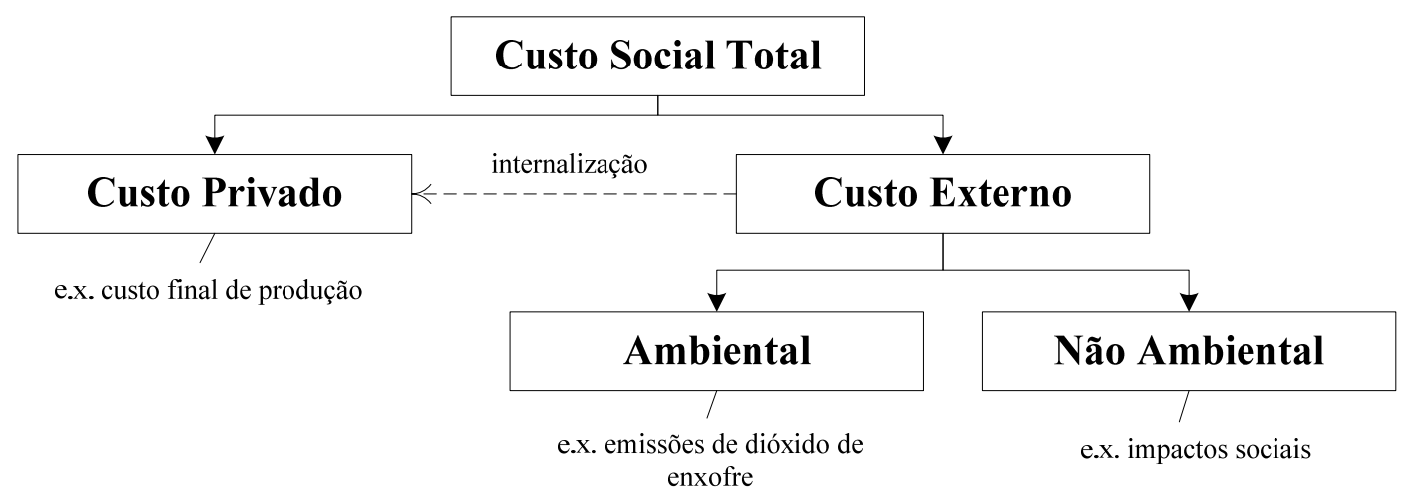

Figura 5.8. Custo social total para uma atividade produtiva.

OTA (2004) apresenta pelo menos cinco métodos são utilizados na avaliação de externalidades voltadas para a geração de energia elétrica. São as valorações de:

- Mercado, que utiliza os dados de um mercado existente de preços para estimar os danos. Este tipo de valoração tem como vantagem a utilização de informações que estão disponíveis e que possuem grau de confiabilidade. Um cuidado especial se faz necessário visto que os preços estão associados com a atividade produtiva. Sendo assim, este tipo de avaliação pode ser falha, pois os preços praticados no mercado podem encontrar-se distorcidos. Além desta limitação, alguns efeitos externos não possuem mercados para se buscar uma precificação, tais como: à saúde e espécies ameaçadas de extinção.

- Contingente, calcada em métodos de pesquisa a partir dos consumidores. Implica num cuidado especial na formulação e execução das pesquisas. Este método é útil para medir os custos onde não existem mercados para se pesquisar os valores, o que já a distingue dos demais métodos de valoração. No entanto, deixa para os consumidores um poder expressivo nos resultados até mesmo influenciando as ações governamentais, o que pode prejudicar a qualidade dos mesmos.

- Hedônica, que examina os preços existentes no mercado para detectar uma valoração implícita dos fatores externos provocado pelos consumidores. Como na valoração de mercado este método tem a vantagem de absorver as escolhas dos consumidores. 
Contudo, ao contrário do método de mercado, todos os fatores que podem influenciar e distorcer o preço precisam ser avaliados além da valoração implícita desejada, ocorrendo o emprego da estatística e de premissas visando segmentar os fatores que compõem o preço o que aumenta a incerteza da informação extraída. Esta análise ainda conta com o mesmo agravante da valoração de mercado quanto às possíveis distorções dos preços;

- Controle, examina as ações de regulação do governo para detectar uma valoração implícita. É uma avaliação considerada simples e com um maior grau de certeza quanto às informações levantadas. No emprego deste método, deve-se tomar o cuidado com as premissas visando manter a confiabilidade da informação. Segundo o Office of Techonology Assessment (OTA), ligado ao congresso do Estados Unidos, esta avaliação pode apresentar uma variação grande em relação aos valores apresentados. No caso brasileiro isto pode ser rebatido para um atendimento às exigências do governo estadual ou federal para um determinado tipo de efeito externo, o que para os autores (OTA, 2004) significa que esta técnica não representa rigorosamente todos os custos envolvidos de fato. Uma justificativa apresentada é que os custos que envolvem a regulação são os custos mínimos apresentados pelo governo;

- Mitigação, que examina o custo de reparar o dano ou a prevenção antes que o dano ocorra. Deve-se ressaltar que este tipo de custo não é o custo devido por ações governamentais como, por exemplo, a regulação. A mitigação é vista com a presunção de um impacto adicional que deve ser evitado podendo até incorrer na reversão do dano inicial.

Estes métodos foram agrupados da seguinte forma:

- Custo do Dano, que abrange as valorações de mercado, hedônica e contingente; e,

- Custo de Controle ou Abatimento, que abrange as valorações de controle e mitigação.

No Brasil, é empregado um método de valoração, no âmbito do licenciamento ambiental, não citado anteriormente, que é a compensação ambiental. Este é um mecanismo financeiro que visa contrabalancear os efeitos de impactos não mitigáveis ocorridos quando da implantação de empreendimentos e identificados na avaliação do processo de licenciamento. Como a 
experiência encontra-se sob o âmbito ambiental, no Brasil, estes recursos são destinados as Unidades de Conservação para a consolidação do Sistema Nacional de Unidades de Conservação - SNUC. O instrumento legal da Compensação está contido no Art. 36 da Lei No 9985 de 18 Julho de 2000 que institui o Sistema Nacional de Unidades de Conservação e regulamentado pelo Decreto $\mathrm{n}^{\mathrm{o}} 4340$, de 22 de agosto 2002, alterado pelo Decreto $\mathrm{n}^{\mathrm{o}}$ 5.566/05.

Poderia se questionar o motivo pelo qual não se citou o custo da compensação ambiental nos métodos de valoração das externalidades. De fato, a compensação ambiental pode ser vista como uma forma de custo de controle visto que é o próprio governo que institui e formula as regras, tais como os valores mínimos, formato de arrecadação e destinação bem como o método de valoração (implícito).

A seguir, são apresentados por Fang e Galen (1994) sete métodos para avaliação de externalidades no planejamento de recursos energéticos. Um comparativo destas abordagens é mostrado na tabela a seguir.

Tabela 5.1. Análise comparativa de metodologias de avaliação de externalidades. Fonte: (Fang \& Galen, 1994)

\begin{tabular}{|c|c|c|}
\hline Método & Pontos fortes & Deficiências \\
\hline & $\begin{array}{l}\text { - Simples } \\
\text { aplicação }\end{array}$ & - $\quad$ Subjetivo \\
\hline $\begin{array}{l}\text { Tratamento } \\
\text { Qualitativo }\end{array}$ & $\begin{array}{l}\text { - Aplicável a aspectos não } \\
\text { quantificáveis }\end{array}$ & $\begin{array}{l}\text { Implícita transferência } \\
\text { de impacto entre opções } \\
\text { - Não pode ser replicado }\end{array}$ \\
\hline $\begin{array}{l}\text { Ponderação e } \\
\text { Ranqueamento }\end{array}$ & $\begin{array}{l}\text { - Alguns elementos } \\
\text { quantitativos } \\
\text { - Mais transparente que o } \\
\text { método qualitativo } \\
\text { - Fácil de implementar } \\
\text { - Elimina a grande } \\
\text { necessidade de dados }\end{array}$ & $\begin{array}{l}\text { - Julgamento adicional s } \\
\text { envolvido na conversão } \\
\text { para aditivos de custos }\end{array}$ \\
\hline
\end{tabular}


continua

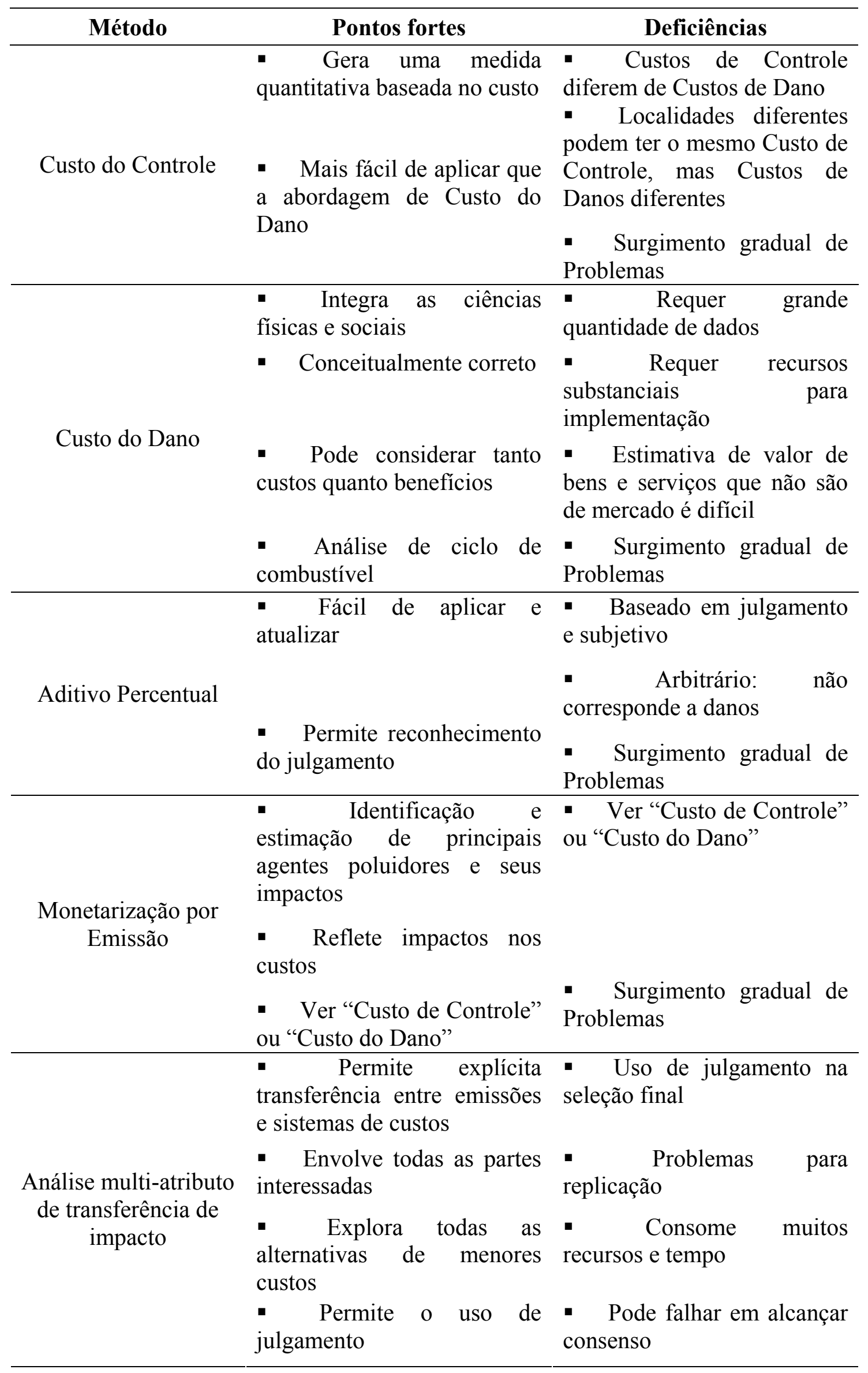


É importante salientar que em ambos os levantamentos metodológicos apresentados (OTA e Fang \& Galen), as metodologias para quantificar e internalizar os custos externos da geração de energia elétrica que se destacam são: os custos do dano e de controle.

A técnica de valoração do custo do dano ainda pode ser subdividida nas análises:

- top-down, onde se utiliza dados agregados para se avaliar um determinado efeito externo. O nível pode ser nacional ou regional, por exemplo. Uma importante crítica para este tipo de análise é que depende da qualidade das informações agregadas e da forma como isso é feito, além da análise se tornar mais genérica impedindo assim um detalhamento maior do objeto de estudo; e,

- bottom-up, utiliza dados específicos da tecnologia de conversão combinada com modelos de dispersão, funções dose-resposta, de danos e impactos e outras informações relevantes sobre a área afetada. A maior crítica quanto este modelo é necessidade massiva de dados para determinar os efeitos externos e na ausência de informações os impactos não são avaliados o que impossibilita uma visão completa do problema.

O custo do controle pode ser interpretado, também, como o valor monetário estimado evitado. Isto é, quanto a sociedade deve pagar para evitar o efeito externo (Furtado, 1996). Assim, os custos internalizados, neste caso, se referem a medidas de mitigação dos efeitos ou medidas para prevenir os impactos.

O custo do dano considera a valoração da avaria ao bem econômico (Pearce, 1992). Este método valora efeitos ambientais como, por exemplo, a perda de produção econômica devido aos impactos de determinado projeto. Seu resultado representa o beneficio que a sociedade terá, evitando a externalidade. Entretanto, a maior dificuldade para utilizar o método de custo do dano é a sua valoração.

Segundo Bernow and Marron (1990) além desta limitação, as preferências da sociedade mudam com o passar do tempo, bem como a informação, os métodos de análise, valores e políticas. Portanto, preferências antigas podem sofrer uma atribuição de valores diferentes quando confrontadas com as opções existentes o que demanda uma constante revisão dos custos. 
$\mathrm{Na}$ impossibilidade da aplicação do custo do dano, o de controle pode ser uma boa opção para incorporação de externalidades. Neste caso, segundo Furtado (1996), existem três grandes desafios relativos à valoração monetária dos efeitos externos:

- descobrir o nível de custo de controle que seja economicamente eficiente;

- determinar o dano evitado como resultado da aplicação das ações de controle; e,

- encontrar o melhor método para estimar o custo real externo envolvido.

Desta mensuração e monetarização dependem as decisões a serem tomadas em relação à internalização do custo externo.

\subsubsection{EXTERNALIDADES NA GERAÇÃO DE ENERGIA - LEVANTAMENTO BIBLIOGRÁFICO}

Partindo dos conceitos apresentados anteriormente, o próximo passo consiste na apresentação dos métodos e técnicas utilizadas para o tratamento dos custos externos aplicados à geração de energia, na prática.

Esta seção é fruto de um levantamento quantitativo dos estudos realizados nos anos 80, 90 e 2000 até o presente momento com o principal foco em avaliar os custos externos, associados com a geração de energia elétrica. Os resultados podem ser sumarizados a seguir: 


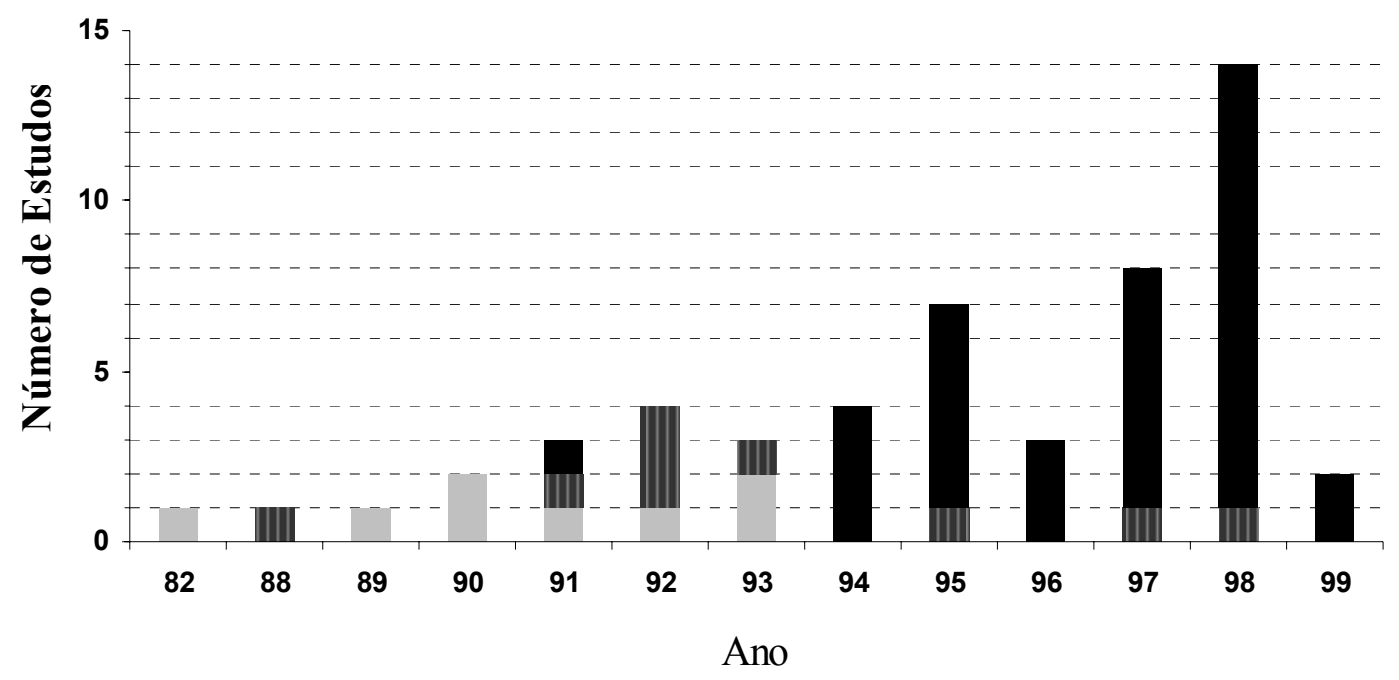

Custo de Controle all Custo do Dano (top-down) a Custo do Dano (bottom-up)

Figura 5.9. Variação das opções metodológicas de avaliação das externalidades ao longo do tempo.

Da figura 5.9. percebe-se que ao longo do tempo a opção metodológica predominante foi a do custo do dano aplicando a avaliação bottom-up.

Do levantamento citado, observa-se:

- as fontes de geração de eletricidade mais estudadas para valoração dos custos externos são: carvão, óleo, gás natural, nuclear, potencial hidráulico, eólica, solar e biomassa; e em alguns casos, o lignito, resíduos e energia geotérmica. Contudo o foco principal dos estudos são as fontes tradicionais tais como carvão e óleo. Há uma tendência dos estudos focarem nas fontes e tecnologias existentes ao invés das possíveis rotas tecnológicas ou novas fontes que podem vir a ocupar uma posição estratégica na matriz energética. $\mathrm{O}$ que restringe o campo de avaliação apenas ao estado atual do parque gerador com o que se tem disponível no mercado sem uma prospecção de médio/longo prazo.

- outro aspecto interessante é que grande parte dos estudos foram realizados por países desenvolvidos (majoritariamente Europa e Estados Unidos). E em poucos casos o foco das análises de externalidades foi voltado aos países em desenvolvimento onde a necessidade por expansão do parque de geração é latente, segundo IEA (1998). 
Sundqvist (2002) acredita que as estimativas das externalidades são substancialmente diferentes quando comparadas entre países desenvolvidos e em desenvolvimento.

- examinando as metodologias utilizadas no transcorrer do tempo com base na figura 5.9. e tabela 5.2., a análise bottom-up com base no método do custo do dano passou a ser a técnica dominante enquanto o método do custo de abatimento ${ }^{66}$ ou a técnica topdown foram utilizados predominantemente nos anos 80 e 90. Uma importante razão para este fato é a implementação do projeto ExternE $(E C, 1999)$ que se baseia no método do custo do dano e na técnica bottom-up. Em Krewitt (2002) afirma-se que a técnica mais apropriada para avaliar as externalidades na geração de eletricidade é a bottom-up. Os resultados encontrados pelo projeto ExternE foram discutidos e difundidos no cenário internacional.

A maioria dos estudos de externalidades na geração de eletricidade focam, normalmente, questões tecnológicas e metodológicas que precisam ser esclarecidas e justificadas para que, em seguida, haja a valoração visando estimar as externalidades. Em Freeman (1996) e Krewitt (2002) há discussões sobre a valoração da externalidade que envolve as emissões de $\mathrm{CO}_{2}$ advinda de combustíveis fósseis e os impactos na mortalidade.

Percebe-se que as escolhas das externalidades consideradas como relevantes nos trabalhos pesquisados diferem dos estudos de avaliação dos mesmos. Isto é, alguns estudos tendem a diferenciar consideravelmente a definição do que constitui uma externalidade. A seguir, dois exemplos serão apresentados para ilustrar este ponto.

Tabela 5.2. Levantamento dos estudos de externalidades na geração de eletricidade. Fonte: Adaptado de Sundqvist (2002)

\begin{tabular}{|c|c|c|c|c|}
\hline Estudo & País & $\begin{array}{c}\text { Fonte } \\
\text { Primária de } \\
\text { Energia } \\
\end{array}$ & $\begin{array}{c}\text { Externalidade } \\
\text { Estimada }\end{array}$ & Método \\
\hline & & & $\begin{array}{c}\text { (Centavos US } \\
\$ / \mathrm{kWh})\end{array}$ & \multirow{3}{*}{$\begin{array}{c}\text { Custo do } \\
\text { Abatimento }\end{array}$} \\
\hline \multirow{3}{*}{$\begin{array}{l}\text { Schuman \& } \\
\text { Cavanagh } \\
\text { (1982) }\end{array}$} & \multirow{3}{*}{ EUA } & Carvão & $0.06-44.07$ & \\
\hline & & Nuclear & $0.11-64.45$ & \\
\hline & & Solar & $0-0.25$ & continua.... \\
\hline
\end{tabular}

${ }^{66}$ Ou custo de controle 
continua

\begin{tabular}{|c|c|c|c|c|}
\hline Estudo & País & $\begin{array}{c}\text { Fonte } \\
\text { Primária de } \\
\text { Energia }\end{array}$ & $\begin{array}{c}\text { Externalidade } \\
\text { Estimada }\end{array}$ & Método \\
\hline & & Eólica & $0-0.25$ & \\
\hline \multirow{4}{*}{$\begin{array}{l}\text { Hohmeyer } \\
\text { (1988) }\end{array}$} & \multirow{4}{*}{ Alemanha } & $\begin{array}{c}\text { Combustíveis } \\
\text { Fósseis }\end{array}$ & $2.37-6.53$ & \multirow{4}{*}{$\begin{array}{l}\text { Custo do Dano } \\
\text { (top-down) }\end{array}$} \\
\hline & & Nuclear & $7.17-14.89$ & \\
\hline & & Eólica & $0.18-0.36$ & \\
\hline & & Solar & $0.68-1.03$ & \\
\hline \multirow{3}{*}{$\begin{array}{c}\text { Chernick \& } \\
\text { Caverhill (1989) }\end{array}$} & \multirow{3}{*}{ EUA } & Carvão & $4.37-7.74$ & \multirow{3}{*}{$\begin{array}{l}\text { Custo do } \\
\text { Abatimento }\end{array}$} \\
\hline & & Óleo & $4.87-7.86$ & \\
\hline & & Gás & $1.75-2.62$ & \\
\hline \multirow{3}{*}{$\begin{array}{c}\text { Bernow \& } \\
\text { Marron (1990); } \\
\text { Bernow et al. } \\
(1991)\end{array}$} & \multirow{3}{*}{ EUA } & Carvão & $5.57-12.45$ & \multirow{3}{*}{$\begin{array}{l}\text { Custo do } \\
\text { Abatimento }\end{array}$} \\
\hline & & Óleo & $4.40-12.89$ & \\
\hline & & Gás & $2.10-7.98$ & \\
\hline Hall (1990) & EUA & Nuclear & $2.37-3.37$ & $\begin{array}{l}\text { Custo do } \\
\text { Abatimento }\end{array}$ \\
\hline \multirow{4}{*}{$\begin{array}{l}\text { Friedrich \& } \\
\text { Kallenbach } \\
\quad(1991) ; \\
\text { Friedrich \& } \\
\text { Voss (1993) }\end{array}$} & \multirow{4}{*}{ Alemanha } & Carvão & $0.36-0.86$ & \multirow{4}{*}{$\begin{array}{l}\text { Custo do Dano } \\
\text { (bottom-up) }\end{array}$} \\
\hline & & Nuclear & $0.03-0.56$ & \\
\hline & & Eólica & $0.02-0.33$ & \\
\hline & & Solar & $0.05-1.11$ & \\
\hline \multirow[t]{4}{*}{$\begin{array}{c}\text { Ottinger et al. } \\
\text { (1991) }\end{array}$} & \multirow{4}{*}{ EUA } & Carvão & $3.62-8.86$ & \multirow[t]{4}{*}{$\begin{array}{l}\text { Custo do Dano } \\
\text { (bottom-up) }\end{array}$} \\
\hline & & Óleo & $3.87-10.36$ & \\
\hline & & Gás & $1.00-1.62$ & \\
\hline & & Nuclear & 3.81 & \\
\hline
\end{tabular}


continua

\begin{tabular}{|c|c|c|c|c|}
\hline Estudo & País & $\begin{array}{c}\text { Fonte } \\
\text { Primária de } \\
\text { Energia }\end{array}$ & $\begin{array}{c}\text { Externalidade } \\
\text { Estimada }\end{array}$ & Método \\
\hline & & Hidrelétrica & $1.43-1.62$ & \\
\hline & & Eólica & $0-0.12$ & \\
\hline & & Solar & $0-0.50$ & \\
\hline & & Biomassa & $0-0.87$ & \\
\hline & & Resíduos & 5.00 & \\
\hline Putta (1991) & EUA & Carvão & 1.75 & $\begin{array}{c}\text { Custo do } \\
\text { Abatimento }\end{array}$ \\
\hline \multirow{4}{*}{$\begin{array}{l}\text { IIHohmeyer } \\
\text { (1992) }\end{array}$} & \multirow{4}{*}{ Alemanha } & $\begin{array}{l}\text { Combustíveis } \\
\text { Fósseis }\end{array}$ & 11.12 & \multirow{4}{*}{$\begin{array}{l}\text { Custo do Dano } \\
\text { (top-down) }\end{array}$} \\
\hline & & Nuclear & $7.01-48.86$ & \\
\hline & & Eólica & $0.12-0.24$ & \\
\hline & & Solar & $0.54-0.76$ & \\
\hline \multirow{7}{*}{$\begin{array}{l}\text { Pearce et al. } \\
\quad(1992)\end{array}$} & \multirow{7}{*}{ Inglaterra } & Carvão & $2.67-14.43$ & \multirow{7}{*}{$\begin{array}{l}\text { Custo do Dano } \\
\text { (top-down) }\end{array}$} \\
\hline & & Óleo & 13.14 & \\
\hline & & Gás & 1.05 & \\
\hline & & Nuclear & 0.81 & \\
\hline & & Hidrelétrica & 0.09 & \\
\hline & & Eólica & 0.09 & \\
\hline & & Solar & 0.15 & \\
\hline $\begin{array}{l}\text { Carlsen et al. } \\
\quad(1993)\end{array}$ & Noruega & Hidrelétrica & $2.68-26.26$ & $\begin{array}{l}\text { Custo do } \\
\text { Abatimento }\end{array}$ \\
\hline \multirow{2}{*}{$\begin{array}{c}\text { Cifuentes \& } \\
\text { Lave (1993); } \\
\text { Parfomak (1997) }\end{array}$} & \multirow{2}{*}{ EUA } & Carvão & $2.17-20.67$ & \multirow{2}{*}{$\begin{array}{l}\text { Custo do } \\
\text { Abatimento }\end{array}$} \\
\hline & & Gás & $0.03-0.04$ & \\
\hline \multirow{3}{*}{$\begin{array}{c}\text { ORNL \& RfF } \\
(1994-1998)\end{array}$} & \multirow{3}{*}{ EUA } & Carvão & $0.11-0.48$ & \multirow[t]{3}{*}{$\begin{array}{l}\text { Custo do Dano } \\
\text { (bottom-up) }\end{array}$} \\
\hline & & Óleo & $0.04-0.32$ & \\
\hline & & Gás & $0.01-0.03$ & \\
\hline
\end{tabular}


continua

\begin{tabular}{|c|c|c|c|c|}
\hline Estudo & País & $\begin{array}{c}\text { Fonte } \\
\text { Primária de } \\
\text { Energia } \\
\end{array}$ & $\begin{array}{l}\text { Externalidade } \\
\text { Estimada }\end{array}$ & Método \\
\hline & & Nuclear & $0.02-0.12$ & \\
\hline & & Hidrelétrica & 0.02 & \\
\hline \multirow{2}{*}{ RER (1994) } & \multirow{2}{*}{ EUA } & Óleo & $0.03-5.81$ & \multirow{2}{*}{$\begin{array}{l}\text { Custo do Dano } \\
\text { (bottom-up) }\end{array}$} \\
\hline & & Gás & $0.003-0.48$ & \\
\hline \multirow{3}{*}{ EC (1995) } & \multirow{3}{*}{ Alemanha } & Carvão & 2.39 & \multirow{3}{*}{$\begin{array}{l}\text { Custo do Dano } \\
\text { (bottom-up) }\end{array}$} \\
\hline & & Óleo & 3.00 & \\
\hline & & Lignito & 1.37 & \\
\hline-- & França & Nuclear & $0.0003-0.01$ & $\begin{array}{l}\text { Custo do Dano } \\
\text { (bottom-up) }\end{array}$ \\
\hline-- & Noruega & Hidrelétrica & 0.32 & $\begin{array}{l}\text { Custo do Dano } \\
\text { (bottom-up) }\end{array}$ \\
\hline \multirow{3}{*}{--} & \multirow{3}{*}{ Inglaterra } & Carvão & 0.98 & \multirow{3}{*}{$\begin{array}{l}\text { Custo do Dano } \\
\text { (bottom-up) }\end{array}$} \\
\hline & & Gás & 0.10 & \\
\hline & & Eólica & $0.11-0.32$ & \\
\hline \multirow{3}{*}{ Pearce (1995) } & \multirow{3}{*}{ Inglaterra } & Carvão & 3.02 & \multirow{3}{*}{$\begin{array}{l}\text { Custo do Danc } \\
\text { (top-down) }\end{array}$} \\
\hline & & Gás & 0.49 & \\
\hline & & Nuclear & $0.07-0.55$ & \\
\hline \multirow{5}{*}{$\begin{array}{l}\text { Rowe et al. } \\
\text { (1995) }\end{array}$} & \multirow{5}{*}{ EUA } & Carvão & 0.31 & \multirow{5}{*}{$\begin{array}{l}\text { Custo do Dano } \\
\text { (bottom-up) }\end{array}$} \\
\hline & & Óleo & 0.73 & \\
\hline & & Gás & 0.22 & \\
\hline & & Nuclear & 0.01 & \\
\hline & & Eólica & 0.001 & \\
\hline \multirow{2}{*}{$\begin{array}{c}\text { van Horen } \\
(1996)\end{array}$} & \multirow{2}{*}{ África do Sul } & Carvão & $0.90-5.01$ & \multirow[t]{2}{*}{$\begin{array}{l}\text { Custo do Dano } \\
\text { (bottom-up) }\end{array}$} \\
\hline & & Nuclear & $1.34-4.54$ & \\
\hline
\end{tabular}


continua

\begin{tabular}{|c|c|c|c|c|}
\hline Estudo & País & $\begin{array}{c}\text { Fonte } \\
\text { Primária de } \\
\text { Energia }\end{array}$ & $\begin{array}{l}\text { Externalidade } \\
\text { Estimada }\end{array}$ & Método \\
\hline $\begin{array}{c}\text { Bhattacharyya } \\
\text { (1997) }\end{array}$ & Índia & Carvão & 1.36 & $\begin{array}{l}\text { Custo do Dano } \\
\text { (bottom-up) }\end{array}$ \\
\hline \multirow{4}{*}{ Ott (1997) } & \multirow{4}{*}{ Suíça } & Óleo & $12.97-20.57$ & \multirow{4}{*}{$\begin{array}{l}\text { Custo do Dano } \\
\text { (top-down) }\end{array}$} \\
\hline & & Gás & $8.85-13.22$ & \\
\hline & & Nuclear & $0.62-1.50$ & \\
\hline & & Hidrelétrica & $0.25-1.50$ & \\
\hline $\begin{array}{c}\text { Faaij et al. } \\
\text { (1998) }\end{array}$ & Países Baixos & Carvão & 3.98 & $\begin{array}{l}\text { Custo do Dano } \\
\text { (top-down) }\end{array}$ \\
\hline \multirow{2}{*}{--} & \multirow{2}{*}{ Países Baixos } & Carvão & 3.84 & \multirow{2}{*}{$\begin{array}{l}\text { Custo do Dano } \\
\text { (bottom-up) }\end{array}$} \\
\hline & & Biomassa & 8.10 & \\
\hline \multirow{3}{*}{ EC (1999) } & \multirow{3}{*}{ Aústria } & Gás & 0.88 & \multirow{3}{*}{$\begin{array}{l}\text { Custo do Dano } \\
\text { (bottom-up) }\end{array}$} \\
\hline & & Hidrelétrica & 0.02 & \\
\hline & & Biomassa & $1.54-7.56$ & \\
\hline \multirow{3}{*}{--} & \multirow{3}{*}{ Bélgica } & Carvão & $3.22-67.72$ & \multirow{3}{*}{$\begin{array}{l}\text { Custo do Dano } \\
\text { (bottom-up) }\end{array}$} \\
\hline & & Gás & $0.67-9.73$ & \\
\hline & & Nuclear & $0.02-0.79$ & \\
\hline \multirow{3}{*}{--} & \multirow{3}{*}{ Dinamarca } & Gás & $0.99-11.19$ & \multirow{3}{*}{$\begin{array}{l}\text { Custo do Dano } \\
\text { (bottom-up) }\end{array}$} \\
\hline & & Eólica & $0.08-0.51$ & \\
\hline & & Biomassa & $2.34-12.55$ & \\
\hline \multirow{2}{*}{--} & \multirow{2}{*}{ Finlândia } & Carvão & $1.07-18.15$ & \multirow[t]{2}{*}{$\begin{array}{l}\text { Custo do Dano } \\
\text { (bottom-up) }\end{array}$} \\
\hline & & Biomassa & $0.83-2.00$ & \\
\hline
\end{tabular}


continua

\begin{tabular}{|c|c|c|c|c|}
\hline Estudo & País & $\begin{array}{c}\text { Fonte } \\
\text { Primária de } \\
\text { Energia } \\
\end{array}$ & $\begin{array}{l}\text { Externalidade } \\
\text { Estimada }\end{array}$ & Método \\
\hline & & Turfa & $0.69-1.69$ & \\
\hline \multirow{5}{*}{--} & \multirow{5}{*}{ França } & Carvão & $9.61-29.45$ & \multirow{5}{*}{$\begin{array}{l}\text { Custo do Dano } \\
\text { (bottom-up) }\end{array}$} \\
\hline & & Óleo & $11.79-39.93$ & \\
\hline & & Gás & $2.70-7.68$ & \\
\hline & & Biomassa & $0.82-2.51$ & \\
\hline & & Resíduos & $22.17-68.73$ & \\
\hline \multirow{6}{*}{--} & \multirow{6}{*}{ Grécia } & Óleo & $2.07-19.89$ & \multirow{6}{*}{$\begin{array}{l}\text { Custo do Dano } \\
\text { (bottom-up) }\end{array}$} \\
\hline & & Gás & $0.57-4.97$ & \\
\hline & & Hidrelétrica & 0.71 & \\
\hline & & Eólica & $0.31-0.80$ & \\
\hline & & Biomassa & $0.14-3.43$ & \\
\hline & & Lignito & $3.67-36.54$ & \\
\hline \multirow{8}{*}{--} & \multirow{8}{*}{ Alemanha } & Carvão & $2.38-23.67$ & \multirow{8}{*}{$\begin{array}{l}\text { Custo do Dano } \\
\text { (bottom-up) }\end{array}$} \\
\hline & & Óleo & $5.30-35.16$ & \\
\hline & & Gás & $0.83-9.55$ & \\
\hline & & Nuclear & $0.08-1.45$ & \\
\hline & & Eólica & $0.05-0.31$ & \\
\hline & & Solar & $0.08-1.69$ & \\
\hline & & Biomassa & $3.78-13.19$ & \\
\hline & & Lignito & $2.83-56.57$ & \\
\hline
\end{tabular}


continua

\begin{tabular}{|c|c|c|c|c|}
\hline Estudo & País & $\begin{array}{c}\text { Fonte } \\
\text { Primária de } \\
\text { Energia }\end{array}$ & $\begin{array}{l}\text { Externalidade } \\
\text { Estimada }\end{array}$ & Método \\
\hline \multirow{2}{*}{-- } & \multirow{2}{*}{ Irlanda } & Carvão & $6.16-31.90$ & \multirow[t]{2}{*}{$\begin{array}{c}\text { Custo do Dano } \\
\text { (bottom-up) }\end{array}$} \\
\hline & & Turfa & $4.62-5.32$ & \\
\hline \multirow{4}{*}{--} & \multirow{4}{*}{ Itália } & Óleo & $3.24-24.52$ & \multirow{4}{*}{$\begin{array}{l}\text { Custo do Dano } \\
\text { (bottom-up) }\end{array}$} \\
\hline & & Gás & $1.21-11.78$ & \\
\hline & & Hidrelétrica & 0.47 & \\
\hline & & Resíduos & -- & \\
\hline \multirow{4}{*}{-- } & \multirow{4}{*}{ Países Baixos } & Carvão & $1.68-24.48$ & \multirow{4}{*}{$\begin{array}{l}\text { Custo do Dano } \\
\text { (bottom-up) }\end{array}$} \\
\hline & & Gás & $0.43-9.65$ & \\
\hline & & Nuclear & 1.03 & \\
\hline & & Biomassa & $0.49-2.86$ & \\
\hline \multirow{4}{*}{--} & \multirow{4}{*}{ Noruega } & Gás & $0.26-8.04$ & \multirow{4}{*}{$\begin{array}{l}\text { Custo do Dano } \\
\text { (bottom-up) }\end{array}$} \\
\hline & & Hidrelétrica & 0.32 & \\
\hline & & Eólica & $0.07-0.35$ & \\
\hline & & Biomassa & 0.33 & \\
\hline \multirow{4}{*}{--} & \multirow{4}{*}{ Portugal } & Carvão & $3.69-30.22$ & \multirow{4}{*}{$\begin{array}{l}\text { Custo do Dano } \\
\text { (bottom-up) }\end{array}$} \\
\hline & & Gás & $0.28-8.74$ & \\
\hline & & Hidrelétrica & $0.03-0.07$ & \\
\hline & & Biomassa & $1.53-8.52$ & \\
\hline \multirow{2}{*}{--} & & Carvão & $4.64-32.60$ & \multirow{2}{*}{$\begin{array}{l}\text { Custo do Dano } \\
\text { (bottom-up) }\end{array}$} \\
\hline & & Gás & $7.13-9.53$ & \\
\hline continua & & & & \\
\hline
\end{tabular}




\begin{tabular}{|c|c|c|c|c|}
\hline Estudo & País & $\begin{array}{c}\text { Fonte } \\
\text { Primária de } \\
\text { Energia } \\
\end{array}$ & $\begin{array}{c}\text { Externalidade } \\
\text { Estimada }\end{array}$ & Método \\
\hline & & Eólica & $0.24-0.34$ & \\
\hline & & Biomassa & $2.41-22.09$ & \\
\hline & & Resíduos & $3.58-26.19$ & \\
\hline \multirow{3}{*}{--} & \multirow{3}{*}{ Suécia } & Carvão & 0.84-16.93 & \multirow{3}{*}{$\begin{array}{l}\text { Custo do Dano } \\
\text { (bottom-up) }\end{array}$} \\
\hline & & Hidrelétrica & $7.83-18.54$ & \\
\hline & & Biomassa & $0.35-0.60$ & \\
\hline \multirow{5}{*}{--} & \multirow{5}{*}{ Inglaterra } & Carvão & $4.06-33.01$ & \multirow{5}{*}{$\begin{array}{l}\text { Custo do Dano } \\
\text { (bottom-up) }\end{array}$} \\
\hline & & Óleo & $3.22-22.10$ & \\
\hline & & Gás & $0.73-10.21$ & \\
\hline & & Eólica & $0.17-0.34$ & \\
\hline & & Biomassa & $0.72-3.22$ & \\
\hline \multirow{8}{*}{$\begin{array}{l}\text { Hirschberg \& } \\
\text { Jakob (1999) }\end{array}$} & \multirow{8}{*}{ Suíça } & Carvão & $4.54-23.16$ & \multirow{8}{*}{$\begin{array}{l}\text { Custo do Dano } \\
\text { (bottom-up) }\end{array}$} \\
\hline & & Óleo & $5.13-26.09$ & \\
\hline & & Gás & $1.17-8.06$ & \\
\hline & & Nuclear & $0.29-1.90$ & \\
\hline & & Hidrelétrica & $0-1.76$ & \\
\hline & & Eólica & $0.15-0.88$ & \\
\hline & & Solar & $0.15-2.20$ & \\
\hline & & Biomassa & $3.67-8.50$ & \\
\hline \multirow{4}{*}{$\begin{array}{l}\text { Maddison } \\
\text { (1999) }\end{array}$} & \multirow{4}{*}{ Inglaterra/Alemanha } & Carvão & $0.31 / 0.71$ & \multirow{4}{*}{$\begin{array}{l}\text { Custo do Dano } \\
\text { (bottom-up) }\end{array}$} \\
\hline & & Óleo & 0.78 & \\
\hline & & Gás & 0.13 & \\
\hline & & Lignito & 0.73 & \\
\hline
\end{tabular}


Das estimativas apresentadas na tabela acima se verifica a disparidade existente entre os custos externos estimados quando comparados os diversos estudos. Mesmo com janelas grandes de variação, o carvão e o óleo são os que apresentam os maiores custos externos enquanto que as fontes renováveis de energia tendem a apresentar menores valores. Em Sundqvist (2002) há um comparativo calcado com base em mais de sessenta estudos de externalidades com o foco nos custos externos ambientais sendo que mesmo considerando todo o ciclo de vida dos combustíveis ao invés de apenas o estágio de geração a conclusão apresentada entre os custos externos e as fontes de energia, é a mesma.

Contudo, deve ficar claro que as variações destes resultados não desqualificam os estudos, visto que realmente isto deve ocorrer, pois se consideram diferentes tecnologias de geração (implicando em diferentes fatores de emissão, por exemplo), características locais (distribuição populacional, por exemplo), diferenças de escopo (ciclo de vida completo da fonte ou apenas o estágio de geração). A dificuldade reside no fato que não há uma referência estabelecida para confrontar estes resultados.

\subsubsection{PRINCIPAIS EXTERNALIDADES APONTADAS PARA A FONTE BIOMASSA}

As externalidades aqui listadas foram levantadas pelo projeto ExternE (EC, 1999). Dentre os estudos analisados é o que apresenta uma listagem mais completa acerca dos custos externos envolvendo tanto a geração de energia elétrica quanto o ciclo do combustível (biomassa).

- Saúde Pública (Câncer e problemas respiratórios; Mortalidade; Redução da expectativa de vida e outras doenças);

- Acidentes em geral;

- Lavoura (relacionado com a erosão, contaminação do solo e água além do uso de químicos);

- Nível de Ruído;

- Impacto Visual;

- Efeito Estufa (uso de equipamentos que consumam combustíveis fósseis);

- Danos a rodovias; 
- Efeitos adversos aos ecossistemas próximos;

Com relação às emissões atmosféricas, os poluentes que dominam os custos externos são os nitratos, particulados e o ozônio.

\subsection{LIMITAÇÕES DA ANÁLISE DE EXTERNALIDADES}

A estimativa dos custos externos apresenta restrições quando objetiva combinar ou comparar os resultados encontrados pelos estudos. Isto ocorre pelos métodos e considerações empregadas na quantificação, o que as tornam úteis apenas para comparações mais genéricas e qualitativas.

Ao mesmo tempo, a avaliação e quantificação das externalidades estimadas apresentam, em si, graus de incerteza. Não somente pela forma de quantificação, mas a incerteza já nasce na concepção do método de avaliação. Como foi apresentado na tabela 5.2. existem custos que variam de praticamente da décima parte 0,1 do centavo de dólar por $\mathrm{kWh}$ gerado a até quase sessenta vezes este valor. Os estudos pecam em não explicitar as incertezas das estimativas.

Porém, OTA (2002) examinou mais de 50 estimativas de externalidades associadas com fontes de energia sendo que em mais de $80 \%$ dos casos, uma categoria de dano dominou a estimativa do custo. Esta observação pode facilitar o uso dos estudos de avaliação de externalidades no processo de tomada de decisão tanto para a proposição de políticas públicas quanto para a atividade de regulação do setor energético. 


\section{ANÁLISES DE EXTERNALIDADES DA INDÚSTRIA SUCROALCOOLEIRA E PROPOSTAS PARA INTERNALIZAÇÃO}

A estrutura desta seção será a mesma do Capítulo 04, isto é, inicialmente se irá valer das atividades em que o ciclo de vida foi desmembrado. Outras questões relativas às externalidades que não estejam diretamente associadas com os indicadores apresentado pelos métodos de avaliação e quantificação de impactos do ciclo produtivo serão tratadas mais adiante.

Isto se justifica, pois os efeitos externos à atividade produtiva da cana-de-açúcar nos meios físico, biótico e socioambiental podem extrapolar os limites do sistema produtivo estabelecido por Ometto (2005), que é a Usina e todas as atividades atreladas a ela.

Com base nos resultados já apresentados, utilizou-se como referência a análise das externalidades com base nos impactos avaliados pelo método EDIP, complementados pelos métodos de exergia e emergia.

A tabela a seguir apresenta uma compilação dos resultados com uma classificação prévia das externalidades quando consideras as categorias de impacto apresentadas no Capítulo 04 bem como uma estimativa da sua classe alocação. 
Tabela 6.1. Compilação dos resultados com baseadas nos métodos de avaliação de impactos.

\begin{tabular}{cccc}
\hline \multirow{2}{*}{ Tipo de Impacto } & \multicolumn{3}{c}{ Externalidade } \\
& Positiva & Negativa & Alocação \\
\hline $\begin{array}{c}\text { Emissóes } \\
\text { atmosféricas }\end{array}$ & $\mathrm{X}$ & Local / Regional \\
$\begin{array}{c}\text { Consumo de } \\
\text { Recursos não- } \\
\text { renováveis }\end{array}$ & & $\mathrm{X}$ & Local / Regional \\
$\begin{array}{c}\text { Consumo de } \\
\text { Recursos renováveis }\end{array}$ & $\mathrm{X}$ & & \\
$\begin{array}{c}\text { Consumo/Excedente } \\
\text { de Energia Elétrica }\end{array}$ & $\mathrm{X}$ & & Local \\
Potencial de & & & Regional \\
Aquecimento Global & & $\mathrm{X}$ & Global \\
$\begin{array}{c}\text { Potencial de Ozônio } \\
\text { Troposférico }\end{array}$ & & $\mathrm{X}$ & Regional \\
$\begin{array}{c}\text { Potencial de } \\
\text { Acidificação }\end{array}$ & & $\mathrm{X}$ & Local \\
Potencial de & & \\
$\begin{array}{c}\text { Eutrofização } \\
\text { Potencial de }\end{array}$ & & $\mathrm{X}$ & Local / Regional \\
Ecotoxicidade & & \\
$\begin{array}{c}\text { Potencial de } \\
\text { Toxicidade Humana }\end{array}$ & $\mathrm{X}$ & Local \\
\hline
\end{tabular}

\subsection{EXTERNALIDADES ASSOCIADAS DIRETAMENTE AO ASPECTO DO CICLO PRODUTIVO DA CANA-DE-AÇÚCAR}

\section{ATIVIDADE 1 - PREPARO DO SOLO}

Considerando a cultura já instalada e a realização de cinco cortes da cana-de-açúcar para realizar a renovação do canavial, as atividades de preparo do solo foram divididas em processo mecânico e químico.

Para a categoria de impactos de emissões atmosféricas as emissões preponderantes desta atividade se devem ao consumo de combustíveis fósseis (Tabela 4.4.) pelas máquinas agrícolas e outros meios de transporte de pessoas e equipamentos. 
Como pode ser visto na Tabela 4.8., o consumo de recursos não renováveis ganha destaque, devido ao alto uso de agroquímicos e, novamente, do consumo de diesel nas máquinas agrícolas, nos caminhões e nos ônibus.

Esta atividade também se destaca com relação ao consumo de recursos renováveis e de um baixo consumo de eletricidade, o que é de se esperar considerando as características desta etapa. O preparo do solo, pelo método de avaliação e valoração EDIP possui um baixo potencial de aquecimento global (Tabela 4.10.), de acidificação (Tabela 4.12.), formação de ozônio troposférico (Tabela 4.11.) e eutrofização (Tabela 4.13.).

No entanto, é a atividade que possui maior grau de ecotoxicidade crônica segundo os resultados alcançados por Ometto (2005) principalmente para a água (Tabela 4.14.); o solo também sofre, mas em quantidades inferiores às demais atividades (2 e 3). Em ambos os casos, tal fato se deve ao uso intensivo de agrotóxicos no solo, o que representa a possibilidade de percolação ou lixiviação para os recursos hídricos.

Considerando os desdobramentos da utilização dos agrotóxicos, do consumo e queima do diesel combustível, dentre os possíveis efeitos de toxicidade humana - via aérea, hídrica e terrestre - o que mais se destaca tanto em relevância quanto nos resultados obtidos da Tabela 4.15., são os da via aérea seguidos em proporções quantitativamente bem inferiores as vias hídricas e terrestres respectivamente.

\section{ATIVIDADE 2 - PLANTIO DA CANA-DE-AÇÚCAR}

Nesta atividade, os equipamentos mais utilizados para o plantio manual são os caminhões para transportar a cana a ser plantada, os tratores com sulcadores e aplicadores de agrotóxicos, além dos ônibus para transportar os trabalhadores.

Na atividade de plantio há, também, a aplicação de agrotóxicos, os quais estão contabilizados a partir de dados primários, considerando-se o total das possíveis combinações médias utilizadas e de fertilizantes com base em dados secundários de Macedo et al. (2004). Ometto (2005) considerou para esta atividade os dados da cadeia produtiva do fertilizante fosfatado $\left(\mathrm{P}_{2} \mathrm{O}_{5}\right)$, esta consideração incrementa alguns dos potenciais avaliados, como por exemplo, o de consumo de recursos (não) / renováveis. 
Pela Tabela 4.4., os níveis de emissões atmosféricas da atividade 2 representam 30,6 \% a menos da atividade 1 em relação ao volume total das emissões. Com relação ao consumo de recursos renováveis (Tabela 4.7.), esta atividade apresenta um baixo consumo em relação à atividade 1 e 3 , cerca de $8 \%$ e $12 \%$ respectivamente. O mesmo fato ocorre também com o consumo de recursos não renováveis (Tabela 4.8.), energia elétrica (Tabela 4.9.), potencial de formação de ozônio troposférico (Tabela 4.11.) e potencial de acidificação (Tabela 4.12.).

No entanto, esta atividade apresenta um potencial de aquecimento global 13 vezes superior em relação à atividade 1 e o maior potencial de eutrofização entre as atividades de 1 a 4 que tratam do cultivo da cana-de-açúcar, visto que ocorre emissão de óxido nitroso pela quantidade de fertilizantes utilizados

Diferentemente da fase anterior, por esta fase também se encontrar associada ao uso mais intensivo de agrotóxicos aplicados diretamente ao solo, esta etapa apresenta a segunda maior ecotoxicidade crônica ao solo, evidenciado pelas informações constantes na Tabela 4.14. Já ao que se refere ao potencial de toxicidade humana (Tabela 4.15.), esta atividade possui um potencial praticamente 3 vezes superior nas vias aéreas e hídricas em relação à atividade 1 , pelos mesmos motivos.

Por fim, os resultados desta atividade num comparativo à anterior, com exceção na redução nas emissões atmosféricas pelo uso do diesel (combustível fóssil) nos veículos de transporte e maquinário agrícola, apresentam uma evolução como conseqüência da intensificação tanto no uso do agrotóxico quanto de fertilizante.

\section{ATIVIDADE 3 - TRATOS CULTURAIS}

A principal atividade dos tratos culturais é a aplicação de agrotóxicos. Os insumos e os adubos consumidos nesta atividade foram obtidos de dados primários e secundários. Assim como na atividade 2 , os dados da cadeia produtiva do fertilizante fosfatado $\left(\mathrm{P}_{2} \mathrm{O}_{5}\right)$ foram utilizados (Ometto, 2005). Novamente, há liberação de óxido nitroso devido à utilização de fertilizantes nitrogenados.

No que se refere às emissões atmosféricas, nota-se um aumento no volume total emitido com destaque para os gases de efeito estufa e o óxido nitroso. Comparativamente, dentre as etapas 1 e 2 esta é a que apresenta mais emissões atmosféricas (Tabela 4.4.). Como é uma etapa 
relativa ao desenvolvimento do cultivo da cana-de-açúcar, o consumo de recursos renováveis é intenso e próximo aos patamares da atividade 1 (Tabela 4.7.). Já no tocante ao consumo dos recursos não renováveis está é a atividade que apresenta o maior consumo com $38,4 \%$ do total, justificáveis pelo alto uso de agroquímicos e consumo de diesel (Tabela 4.8.). O potencial de aquecimento global aumenta em $52 \%$ em relação à atividade 2 , pelo incremento no uso de fertilizantes e no consumo de combustíveis fósseis (Tabela 4.10.). O potencial de formação de ozônio troposférico (Tabela 4.11.), acidificação (Tabela 4.12.) e o consumo de energia (Tabela 4.9.) apresentam quantitativos ainda baixos nesta fase.

O potencial de eutrofização (Tabela 4.13.) é inferior ao da atividade 2, não representando um resultado que seja significativo para ser considerado nesta etapa como um impacto relevante.

Esta fase também se encontra associada a um uso mais intensivo de agrotóxicos aplicados diretamente ao solo o que implicou no maior resultado de ecotoxicidade crônica ao mesmo com um incremento relativamente considerável em relação à atividade 2 no que se refere aos efeitos crônicos na água, conforme a Tabela 4.14. No que se refere ao potencial de toxicidade humana (Tabela 4.15.), esta atividade possui um potencial praticamente idêntico para a via aérea e $50 \%$ superior para a via hídrica, pelos mesmos motivos do incremento ocorrido na atividade 2 em relação a 1 .

Por fim, observando as três etapas conjuntamente, para Ometto (2005), a atividade de preparo do solo é a de maior potencial de impacto para as categorias de consumo de recursos nãorenováveis e o potencial de ecotoxicidade. A principal causa desses altos potenciais é o uso intensivo de diesel e de agrotóxicos, respectivamente. Na atividade de plantio as causas são as mesmas da atividade anterior, no entanto, devido ao incremento na quantidade de fertilizantes e agroquímicos os impactos se acentuam, tais como: aquecimento global, eutrofização e ecotoxicidade crônica ao solo. A atividade de tratos culturais apresenta-se como a de maior potencial para as categorias de eutrofização e de ecotoxicidade do solo; isso se deve ao uso intensivo de agroquímicos.

Para Centurion et al (2001) o cultivo da cana gera a degradação das propriedades físicas do solo em relação ao natural (mata). Esta degradação foi quantificada através de maiores valores de resistência do solo à penetração e menores valores de velocidade de infiltração de água e, independente das formas de manejo, ele conclui que as propriedades físicas do solo são mais afetadas que as propriedades químicas no processo da cultura canavieira. 
Diante das informações apresentadas para as três primeiras atividades produtivas, as externalidades associadas aos impactos destacados pelo método EDIP e discutidos acima, são predominantemente negativos.

Tabela 6.2. Externalidades levantadas nas atividades 1, 2 e 3.

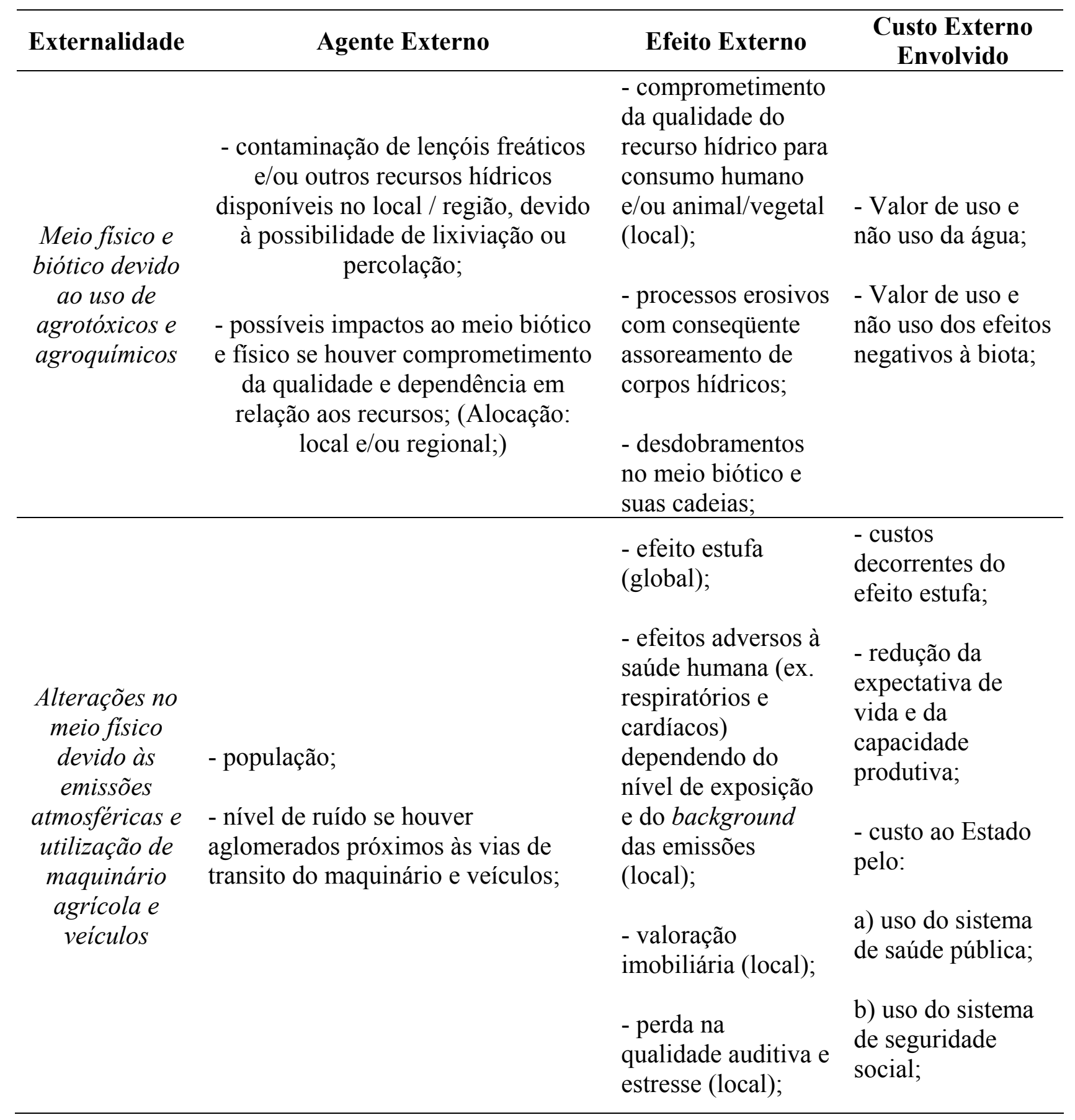


Das duas externalidades apontadas, ambas podem ser controladas, por exemplo, pelo órgão ambiental. O controle não visa eliminar a externalidade, mas minimizá-la dentro do possível sob as seguintes formas:

- solicitação de um plano de monitoramento e controle das emissões. Basicamente, visando forçar com que o responsável mantenha os maquinários devidamente regulados e atendendo os padrões de emissões previstos na legislação além de prover equipamentos de proteção individuais;

- ao mesmo tempo, o órgão ambiental dependendo da existência ou não de aglomerados humanos próximos às vias de acessos ou das áreas de cultivo, pode solicitar no mesmo plano de controle, as medições e ações corretivas (se houver) visando reduzir os níveis de ruído aos aceitáveis pela legislação vigente;

- implantação de um plano de controle do uso de agrotóxicos com o monitoramento da qualidade da água (lençóis freáticos e/ou demais corpos hídricos passíveis de serem afetados) e do solo;

Tais planos podem ser entregues antes do início da atividade para aprovação do órgão e os resultados sumarizados após cada safra e encaminhados para controle do órgão ambiental com a possibilidade de ações de fiscalização durante a implementação dos planos. Outra forma seria priorizar uma frota de máquinas e veículos que utilizem combustíveis cujos efeitos relativos às emissões e níveis de ruído sejam inferiores aos existentes seja por novas rotas tecnológicas ou por renovação de frota. Também coexiste a possibilidade de investimentos em pesquisa \& desenvolvimento para técnicas nesta fase de cultivo que reduzam ou que até mesmo eliminem o uso dos agrotóxicos e agroquímicos mais ofensivos e que possuam um tempo de residência considerado alto no meio.

\section{ATIVIDADE 4 - COLHEITA DA CANA-DE-AÇÚCAR}

A colheita de cana-de-açúcar pode ser feita a partir de cana queimada ou da cana crua. Ometto (2005) levou em consideração no seu levantamento, os dados de Macedo et al. (2004) sobre o modo de colheita no Estado de São Paulo, os quais se assemelham aos dados primários 
levantados por ele, distribuídos da seguinte forma: 63,8 \% manual; 36,2 \% mecânica; 75 \% queimada e $25 \%$ crua.

$\mathrm{Na}$ etapa de colheita manual, há uso de ônibus e vans que consomem diesel para transportar os trabalhadores. Em todos os casos, é necessário transportar a cana-de-açúcar da área de colheita para a indústria por meio de caminhões. Pelos dados primários, esse transporte é feito $30 \%$ por treminhões (cana inteira) e $70 \%$ por rodoanéis (cana cortada) (Ometto, 2005). Para as operações com as máquinas agrícolas, há o consumo, também, de combustível, como já foi apresentado anteriormente.

Anteriormente, foi apresentada a quantidade de $\mathrm{CO}_{2}$ emitido pela queimada na etapa da avaliação do ciclo sendo indicada como emissão atmosférica, mesmo ela sendo absorvida no crescimento da cana, a fim de se verificar a grande quantidade de gás carbônico que se emite em um curto período de tempo, durante o qual a queimada ocorre. No entanto, como foram mostrados nos demais resultados apresentados no Capítulo 4, estas emissões não são consideradas na avaliação dos impactos.

A atividade 4, pela Tabela 4.4., é a de maior volume de emissões atmosféricas dentre todas as atividades destacadas para análise do ciclo produtivo em questão. Com a exceção de óxido nitroso $\left(\mathrm{N}_{2} 0\right)$, onde as atividades 1,2 e 3 possuem a maior participação nas emissões, todas as demais substâncias são emitidas em quantidades superiores às demais atividades.

Como pode ser visto na Tabela 4.7., o consumo de recursos renováveis para execução da atividade é a mais baixa em relação às demais. Já no tocante ao consumo dos recursos não renováveis (Tabela 4.8.), a atividade 4 apresenta um consumo dentro da média quando considerado os consumos das atividades 1,2 e 3 . De fato isto ocorre, pois nessa etapa também há consumo de combustíveis fósseis. No que se refere ao consumo de energia (Tabela 4.9.), esta etapa é a que apresenta o maior consumo, novamente comparando-se com as demais etapas do ciclo agrícola da cana, motivado pelo intenso consumo de combustíveis fósseis para o maquinário envolvido na atividade e dos veículos de transporte de pessoas e materiais.

Com relação ao potencial de aquecimento global (Tabela 4.10.), a etapa de colheita da cana é a que apresenta maior potencial para o efeito estufa, principalmente, pelas emissões de metano, monóxido de carbono e gases de hidrocarbonetos além do dióxido de carbono emitido pelo uso do diesel nos equipamentos agrícolas e veículos de transporte de pessoas e materiais (ressalta-se, conforme já exposto anteriormente, que o $\mathrm{CO}_{2}$ oriundo do processo de 
queimada não é contabilizado para avaliação deste potencial). No que se refere ao potencial de formação de ozônio troposférico, esta também é a atividade que apresenta maior participação dentre todas as apresentadas para avaliação do ciclo produtivo. Isto ocorre devido aos hidrocarbonetos, $\mathrm{NO}_{2}$ e $\mathrm{NO}_{\mathrm{x}}$ emitidos durante a queimada da cana.

De acordo com a Tabela 4.12., que trata do potencial de impacto para acidificação, a atividade 4 (colheita de cana) é a de maior impacto em relação a todas as outras, sendo devido, principalmente, às emissões dos óxidos de nitrogênio durante o processo de queimada da cana. Com relação ao potencial de eutrofização (Tabela 4.13.), esta atividade apresenta um dos mais baixos potenciais em relação às vistas anteriormente (atividades 1, 2 e 3) o que é de se esperar, normalmente, de um processo de colheita.

Analisando o potencial de ecotoxicidade (Tabela 4.14.), esta é a etapa que apresenta menor potencial em comparação as atividades relacionadas com ciclo agrícola da cana quando analisado o efeito crônico na água e no solo concomitantemente. Destacando-se que o efeito crônico ao solo apresenta resultados superiores ao da água estando relacionado ao depósito de particulados provenientes dos processos de queima e emissões.

Por fim, o potencial de toxicidade humana (Tabela 4.15.) para esta atividade é o que apresenta os maiores resultados levando em conta todas as atividades analisadas para o ciclo produtivo da cana em todas as vias: aérea, hídrica e terrestre sendo que o resultado mais expressivo é a da via aérea. Isto ocorre não só pelas emissões apresentadas pela Tabela 4.4., mas também pelas emissões de particulados, aspecto pouco discutido pelo trabalho de Ometto (2005). Como o assunto é de relevância tanto para esta atividade quanto para a de geração de energia elétrica (aos particulados emitidos durante o uso energético do bagaço para geração de energia, mesmo ocorrendo em menores proporções) e carecem de que seus os efeitos externos com relação à saúde humana sejam abordados e correlacionados.

Arbex (2002) apresentou um estudo epidemiológico de séries temporais que avalia a associação entre o material particulado, coletado durante a queima de plantações de cana-deaçúcar e a incidência de doenças respiratórias em Araraquara-SP. Entre os meses de maio e agosto, o numero diário de pacientes que necessitaram de inalações em um dos principais hospitais da cidade foi quantificado e utilizado para estimar a morbidade respiratória. Para estimar o nível da poluição do ar foi quantificado diariamente o peso do sedimento do material particulado proveniente da fuligem da cana-de-açúcar, obtido por sedimentação 
simples, coletado em dois pontos da cidade, um localizado no centro e o segundo na zona rural. A associação entre o peso do sedimento e o numero de pacientes que necessitaram de terapia inalatória foi avaliada. Encontrou-se uma associação positiva significante e dosedependente entre o numero de terapias inalatórias e o peso do sedimento. A relação entre poluição atmosférica e efeitos sobre a saúde da população mostrou ter um efeito agudo após curto período de exposição, com um tempo de defasagem de dois dias. Os resultados indicam que a queima das plantações da cana-de-açúcar podem causar efeitos deletérios à saúde da população exposta. Por fim, o autor recomenda um levantamento em campo mais detalhado e de médio prazo visando melhor caracterizar o fenômeno observado.

Segundo ExternE (2005), em termos de custos, os impactos à saúde são os que contribuem mais nas estimativas dos danos, pois há um consenso entre os especialistas em poluição do ar e de saúde que, mesmo sem um fundo de emissão considerável, existe um incremento nos indicadores de doenças respiratórias e cardiovasculares bem como da mortalidade. Ainda não há uma certeza sobre quais são as causas específicas, mas identificou-se que as partículas finas e a presença do ozônio troposférico possuem implicações diretas. Em termos de custos, podem-se identificar duas componentes a serem estudas acerca deste assunto: uma de curto prazo, onde se analisa os impactos da exposição à poluição por poucos dias; uma segunda componente seria a de efeitos crônicos, indicando os efeitos de longo prazo.

Diante das informações apresentadas para as três primeiras atividades produtivas, as externalidades associadas aos impactos destacados pelo método EDIP e discutidos acima, são predominantemente negativos. 
Tabela 6.3. Externalidades levantadas na atividade 4.

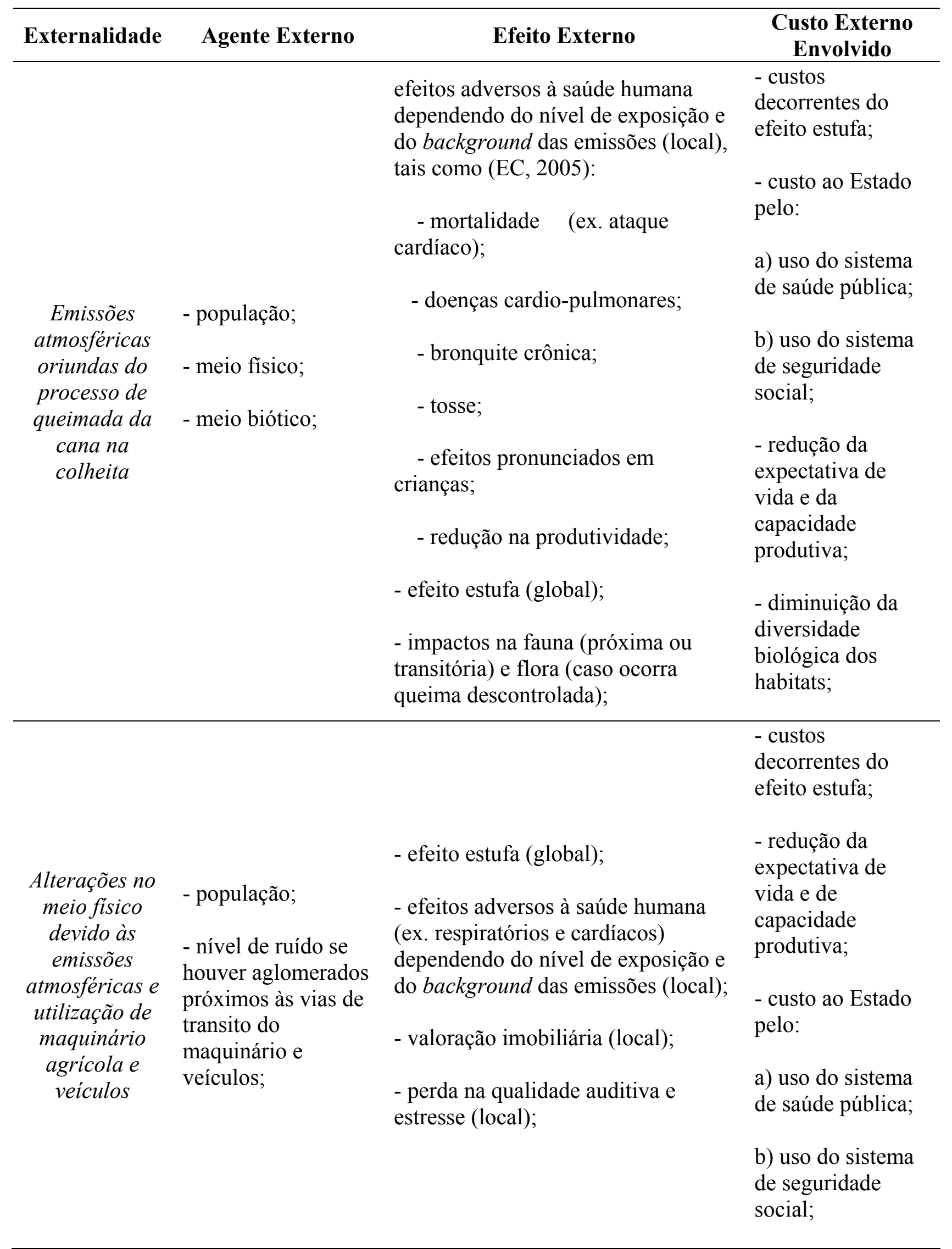


Por fim, conclui-se que a atividade da colheita de cana é a de maior potencial impacto para: o aquecimento global, formação fotoquímica de ozônio troposférico, a acidificação e a toxicidade humana. A principal causa de esta atividade ser a de maior potencial para estas categorias é a queima da palha da cana-de-açúcar. Segundo resultados apresentados por Ometto (2005), a contribuição da queimada da palha, frente ao total de perda exergética das emissões atmosféricas é, de aproximadamente, 91,0\% e recomenda-se a utilização da cana crua para o processamento industrial do álcool com o uso da palha para cogeração de energia, juntamente com o bagaço.

A Companhia de Tecnologia de Saneamento Ambiental (CETESB) também apresenta as seguintes recomendações, visando reduzir os efeitos externos à fauna:

- realizar as queimadas de forma unidirecional visando permitir a fuga dos animais para áreas do entorno;

- realizar, preferencialmente, a queimada no sentido das áreas florestadas com intuito de direcionar a fauna às mesmas; $\mathrm{e}$,

- exige a formação de aceiros para a proteção das áreas florestadas, conforme legislação estadual, visando a preservação dos locais de fuga da fauna a ser impactada.

Além disso, o Decreto $N^{o} 47.700 / 2003$ em seus artigos $4^{\circ}, 5^{\circ}, 6^{\circ}$ e $7^{\circ}$ regulamentam as formas como se darão as queimadas enquanto estas não forem totalmente eliminadas (ano 2021 para áreas $100 \%$ mecanizáveis e 2031 para áreas não mecanizáveis com declividade superior a 12 $\%$ e/ou menores que 150 ha - conforme o decreto supracitado).

No entanto, o processo de colheita de cana, como será visto a diante, traz consigo outros impasses e paradigmas. Um deles, por exemplo, corrobora com os resultados encontrados por Ometto (2005) onde a atividade de colheita possui a maior demanda por mão-de-obra em relação às fases de preparo, plantio e trato cultural da cana-de-açúcar. 


\section{ATIVIDADE 5 - PRODUÇÃO INDUSTRIAL DO ÁLCOOL ETÍLICO HIDRATADO COMBUSTÍVEL}

As considerações adotadas e o tratamento dos dados para os fluxos de entrada do processo industrial estão indicados a seguir e referenciados para uma produção de 1 tonelada de álcool (Ometto, 2005):

- água de lavagem da cana: consumo de 125,760 tágua;

- água de embebição: consumo de 3.000 kg;

- água de lavagem das dornas de fermentação: consumo de 314,40 kg;

- água de resfriamento da fermentação: consumo de 62,50 kg;

- água de resfriamento dos condensadores: consumo de $62,50 \mathrm{~kg}$;

- óleo lubrificante: consumo de $0,21 \mathrm{~kg}$;

- quaternário de amônia ${ }^{67}$ : um consumo de 0,0015 kg;

- polímero para decantação: um consumo de 0,0015 kg;

- ácido sulfúrico $\left(\mathrm{H}_{2} \mathrm{SO}_{4}\right)$ : consumo de $11,31 \mathrm{~kg}$;

- óleo antiespumante: consumo de $0,15 \mathrm{~kg}$;

- uréia: é de 0,003 kg;

- soda: o consumo é de $0,0025 \mathrm{~kg}$;

- energia: consomem-se 2.640 toneladas de vapor, distribuídos metade em forma de vapor e metade para geração de eletricidade, a qual é necessária suprir a demanda da indústria. Para produzir 1 tonelada de álcool, são consumidas 5,5 toneladas de vapor $\mathrm{t}_{\text {vapor, }}$, sendo 2,75 $\mathrm{t}$ vapor consumido diretamente na forma de vapor e, 2,75 $\mathrm{t}$ vapor consumidas para geração de energia elétrica. Considerando-se a média dos dados levantados em campo na geração que é 0,125

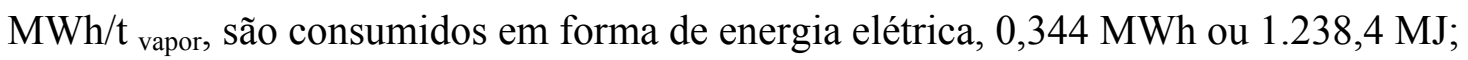

\footnotetext{
${ }^{67}$ Tem função como biocida e é utilizado, pelos dados primários levantados por Ometto (2005), na concentração de 1,5 ppm do álcool produzido.
} 
Dando continuidade à análise e observando as saídas da análise de inventário desta atividade de produção industrial, se fez as seguintes considerações (Ometto, 2005):

- as quantidades de saída de água na lavagem da cana, água de resfriamento dos condensadores da destilaria e água de lavagem das dornas de fermentação são iguais às quantidades consideradas na entrada;

- para a produção de referência, segundo os dados primários, a quantidade gerada de bagaço de cana-de-açúcar é de 4,085 t;

- a quantidade média gerada de vinhaça é de 15 litros por litro de álcool produzido, com massa específica, aproximadamente, igual a 1;

- as quantidades de saída de ácido sulfúrico, óleo antiespumante, soda e óleo lubrificante das moendas são iguais às quantidades de entrada;

- a quantidade gerada de torta de filtro, segundo Ometto (2000), é de 40,0 kg, para cada tonelada de cana-de-açúcar moída;

Segundo Ometto (2005) a emissão de $\mathrm{CO}_{2}$ gerado na fermentação do caldo não foi considerada, por não apresentar informações confiáveis no levantamento em campo. Além disso, esta substância é absorvida durante o ciclo de crescimento da cana. Ademais, não se contabilizaram outras formas de emissões nesta etapa, justificando a ausência da atividade na

\section{Tabela 4.4.}

De acordo com a Tabela 4.9., a atividade que apresenta maior consumo de energia seja de ordem térmica quanto elétrica é a da produção industrial. Esta etapa quando analisada sob o ponto de vista do consumo dos recursos não renováveis apresenta uma participação, comparativamente com as demais atividades, inferior à $1 \%$ (Tabela 4.8.).

No entanto, quando esta atividade é analisada sob a ótica do consumo de recursos renováveis (Tabela 4.7.), ela se destaca em relação a todas as demais, principalmente pelo alto consumo de água, sendo a etapa de lavagem de cana, a maior consumidora deste recurso. Na avaliação do potencial de formação de ozônio troposférico e de aquecimento global, ambas as atividades pelos resultados apresentados na Tabela 4.11. e Tabela 4.10. são nulos. 
Quanto ao potencial de acidificação (Tabela 4.12.) a atividade 5 apresentou uma participação nula pela avaliação EDIP, já para o potencial de eutrofização (Tabela 4.13.) há um baixo potencial em relação às atividades ligadas ao ciclo agrícola e ao industrial, tendo um percentual inexpressivo, comparativamente a elas. A avaliação não apontou potenciais para ecotoxicidade crônica (Tabela 4.14.) tanto para água quanto para o solo. A atividade 5 não apresenta potencial de toxicidade humana pelos dados da Tabela 4.15. em todas as vias (aérea, hídrica e terrestre).

Encontrou-se em grande parte das licenças ambientais expedidas pelo órgão ambiental estadual e apresentadas nos documentos de concepção de projeto MDL, condicionantes relativas à:

- racionalização no consumo da água industrial e utilização da mesma em circuito fechado bem como a exigência legal do não lançamento da água captada em condições inferiores às do momento de captação; e,

- as licenças também abrangem a gestão, controle e uso de resíduos (ex. lodo, lubrificante, torta de filtro, vinhaça e bagaço, etc.). Há também a indicação do uso apropriado da torta de filtro junto com as cinzas para adubação orgânica.

Diante destas informações, não foram encontradas externalidades que já não tenham mecanismos de internalização aplicados, levando em consideração os resultados encontrados via avaliação de impactos do ciclo produtivo da cana.

\section{ATIVIDADE 6 - GERAÇÃO DE VAPOR E DE ENERGIA ELÉTRICA}

A atividade de geração de vapor e de energia elétrica é realizada por meio da queima do bagaço da cana-de-açúcar em caldeiras. As considerações relacionadas ao tratamento dos dados desta atividade, com base em levantamento de dados primários, são (Ometto 2005):

- como foi dito na atividade 5, na produção de 1 tonelada de álcool, geram-se 4,085 toneladas de bagaço;

- $1 \mathrm{~kg}$ bagaço gera $2 \mathrm{~kg}$ vapor. Portanto 4,085 $\mathrm{t}$ bagaço geram 8,17 t vapor. Como são consumidas, no processo industrial, 2,75 $\mathrm{t}$ vapor $\mathrm{em}$ forma de eletricidade, e mais 2,75 $\mathrm{t}$ vapor para o processo 
industrial, havendo uma sobra de 2,67 $\mathrm{t}$ vapor ou 32,68\% passíveis de serem utilizados para geração de eletricidade excedente. Considerando a média dos dados primários de geração, são consumidos 0,334 MWh de eletricidade para a produção de 1 tonelada de álcool. Dessa forma, são alocados, para o álcool, 67,32 \% dos aspectos e impactos ambientais da atividade de cogeração, isto é, 32,68 \% dos impactos estão vinculados à geração de energia;

- para cada $1 \mathrm{~kg}$ bagaço, são consumidos $2 \mathrm{~kg}$ água de reposição;

- a quantidade de água para a refrigeração de óleos dos mancais do turbogerador e de água no trocador de calor no gerador é de $20 \mathrm{~m}^{3} / \mathrm{MWh}$. Com a quantidade de bagaço utilizado e a respectiva energia gerada, o consumo de água para tais fins é de 13,56 t.

- a quantidade total de óleo lubrificante para a produção de referência é de $0,01 \mathrm{~kg}$.

- a quantidade de cinzas geradas na queima do bagaço, considerando a produção de referência, é de $97,41 \mathrm{~kg}$ cinzas, cerca de 2,4 \% da quantidade de bagaço considerado;

- como já foi dito anteriormente, a quantidade de $\mathrm{CO}_{2}$ emitido pela queima do bagaço foi indicada na tabela 4.4. como emissão atmosférica, a fim de se verificar a quantidade que se emite nas chaminés, apesar de reabsorvido no ciclo agrícola da cana (crescimento). Sendo, portanto, não contabilizada para a avaliação do potencial de efeito estufa e demais impactos pelo EDIP. Entretanto, é considerada para a avaliação exergética, pois esta avalia o trabalho que o meio deve absorver, independente da quantia emitida no meio retornar a esse sistema;

- o vapor produzido é utilizado na atividade 5 e por isso não é considerado como emissão atmosférica;

Como pode ser visto na análise das emissões atmosféricas apresentadas pela Tabela 4.4., as emissões mais relevantes nesta etapa, são o $\mathrm{NO}_{\mathrm{x}}$ e o CO. A emissão de particulado, apesar de não ser detalhada por Ometto (2005) e ser uma forma de emissão relevante, já foi tratada no item anterior. Contudo, mais adiante, serão apresentados os custos externos envolvidos por esta componente (particulado) na atividade de geração de energia. Ressalta-se que os limites de emissões agudas no ar pela legislação estadual são mais restritivos que os exigidos pela legislação federal. 
O consumo de recursos renováveis (Tabela 4.7.) para esta atividade também se destaca, principalmente, pelo consumo de água empregada no ciclo de potência que utiliza vapor d'água.

Considerando que é nesta atividade que ocorre a geração de energia térmica e elétrica e que ambas suprem as necessidades internas da usina com a possibilidade de geração de excedentes de eletricidade, o resultado apresentado na Tabela 4.9. é apresentado com sinal negativo indicando que não há consumo, mas sim geração de energia.

Quanto ao potencial de eutrofização (Tabela 4.13.) a atividade 6 apresenta uma pequena participação devida, predominantemente, às cinzas oriundas do processo de queima do bagaço da cana. Sendo este potencial baixo quando considerado o volume de material (menos de 0,1 \%) em relação aos demais. Analogamente, os resultados do potencial de aquecimento global (Tabela 4.10.) e consumo de recursos não renováveis (Tabela 4.8.) são desprezíveis.

Como era de se esperar, a atividade 6 apresenta o segundo maior potencial de toxicidade humana (desconsiderando a atividade 9 e sendo inferior apenas à atividade 4) pela via aérea e não apresentando potenciais para as vias hídricas e terrestres (Tabela 4.15.). O resultado pronunciado ocorre pelo fato desta etapa estar calcada no aproveitamento energético do bagaço da cana-de-açúcar via queima nas caldeiras sendo os gases provenientes da combustão emitidos para a atmosfera por chaminés. A formação de ozônio troposférico (associado às emissões de $\mathrm{NO}_{\mathrm{x}}$ ) e a emissão de particulados são os principais impactos associados pelas emissões atmosféricas desta atividade, sendo que para a questão dos particulados, este é um problema que possui remediação diante da instalação de equipamentos que visam reduzir a sua emissão, tais como o precipitador eletrostático, filtros manga ou lavadores de gás, segunda Lora (1998). Contudo, a avaliação pelo método EDIP não apontou potenciais para ecotoxicidade crônica (Tabela 4.14.) tanto para água quanto para o solo.

Quanto ao potencial de acidificação (Tabela 4.12.) a atividade 6 apresentou a segunda maior participação (excluindo-se a atividade 9), mas comparativamente é inferior aproximadamente em oito vezes ao potencial apresentado pela atividade de queimada da cana (atividade 4). A existência deste potencial na atividade de geração de energia se deve predominantemente às emissões de $\mathrm{NO}_{x}$. 
Encontrou-se em grande parte das licenças ambientais expedidas pelo órgão ambiental estadual e apresentadas nos documentos de concepção de projeto MDL, condicionantes relativas à:

- lavagem dos gases provenientes da caldeira (objetivando reduzir os impactos nas emissões atmosféricas, principalmente os relativos às emissões de particulados);

- sistema de decantação em piscinas de lavagem de cinza com a incorporação dos resíduos na aplicação da vinhaça; e,

- gestão, controle e uso dos resíduos sólidos (cinzas + torta de filtro) como adubação orgânica. 
Tabela 6.4. Externalidades levantadas na atividade 6 .

\begin{tabular}{|c|c|c|c|}
\hline $\begin{array}{l}\text { Externalidade } \\
\text { positiva }\end{array}$ & Agente Externo & Efeito Externo & $\begin{array}{c}\text { Custo Externo } \\
\text { Envolvido }\end{array}$ \\
\hline $\begin{array}{l}\text { Geração de } \\
\text { eletricidade }\end{array}$ & $\begin{array}{l}\text { - população e o } \\
\text { meio ambiente; } \\
\text { - concessionárias } \\
\text { de distribuição de } \\
\text { energia; } \\
\text { - } \\
\text { comercializadoras } \\
\text { de energia } \\
\text { elétrica; }\end{array}$ & $\begin{array}{l}\text { - redução na emissão de gases de efeito } \\
\text { estufa; } \\
\text { - deslocamento de energia proveniente de } \\
\text { combustíveis fósseis; } \\
\text { - serviço de energia: economia de escopo } \\
\text { (energia gerada sob as formas térmica e } \\
\text { elétrica sendo que o excedente é } \\
\text { comercializado) ao invés de economia de } \\
\text { escala (geração centralizada); } \\
\text { - auxilia na equalização da carga pelo } \\
\text { distribuidor local; } \\
\text { Alocação: global }\end{array}$ & $\begin{array}{l}\text { - mitigação dos } \\
\text { custos } \\
\text { decorrentes do } \\
\text { efeito estufa; } \\
\\
\text { - remuneração via } \\
\text { comercialização } \\
\text { de créditos de } \\
\text { carbonos; }\end{array}$ \\
\hline $\begin{array}{c}\text { Externalidade } \\
\text { negativa }\end{array}$ & Agente Externo & Efeito Externo & $\begin{array}{c}\text { Custo Externo } \\
\text { Envolvido }\end{array}$ \\
\hline $\begin{array}{c}\text { Emissões } \\
\text { atmosféricas } \\
\text { provenientes da } \\
\text { queima do } \\
\text { bagaço para } \\
\text { fins de geração } \\
\text { de energia }\end{array}$ & $\begin{array}{l}\text { - população; } \\
\text { - meio físico; } \\
\text { - meio biótico; }\end{array}$ & $\begin{array}{l}\text { efeitos adversos à saúde humana } \\
\text { dependendo do nível de exposição e do } \\
\text { background das emissões (local), tais como } \\
\text { (EC, 2005): } \\
\text { - mortalidade (ex. ataque cardíaco); } \\
\text { - doenças cardio-pulmonares; } \\
\text { - bronquite crônica; } \\
\text { - tosse; } \\
\text { - efeitos pronunciados em crianças; } \\
\text { - redução na produtividade; } \\
\text { - formação de ozônio (NO } \mathrm{NO}_{\mathrm{x}} \text { - catalizador) } \\
\text { (regional/local); } \\
\text {-emissões de particulados (local); } \\
\text { - efeitos adversos ao meio biótico (local); }\end{array}$ & $\begin{array}{l}\text { - custo ao Estado } \\
\text { pelo: } \\
\text { a) uso do sistema } \\
\text { de saúde pública; } \\
\text { b) uso do sistema } \\
\text { de seguridade } \\
\text { social; } \\
\text { - redução da } \\
\text { expectativa de } \\
\text { vida e da } \\
\text { capacidade } \\
\text { produtiva; }\end{array}$ \\
\hline
\end{tabular}

\section{SIMULAÇÃO NO MODELO ExternE}

Para finalizar a análise das externalidades relacionadas à atividade de geração de energia, empregou-se o uso da ferramenta ECOSENSE LE - disponível na internet, no site do projeto 
ExternE. Esta versão é simplificada em relação ao software propriamente dito. A versão disponível na web não contém todas as funcionalidades já mencionadas do modelo ECOSENSE. Contudo, a parte de avaliação das emissões atmosféricas, está disponível e pronta para atualização.

Antes de apresentar os resultados, algumas premissas devem ser apresentadas:

- foi utilizado o arquivo de funções dose-resposta mais atualizado oficialmente pelo projeto ExternE; este data de 2005;

- estas funções já englobam as melhorias ocorridas na metodologia ExternE. Ver EC (2005) para maiores detalhes;

- os valores utilizados como parâmetros de entrada nos cálculos estão baseados nos valores encontrados por Ometto (2005) e apresentados e discutidos neste trabalho, sob a ótica da avaliação das externalidades do ciclo produtivo da cana;

- como o foco deste trabalho é avaliar as externalidades associadas à geração de energia elétrica, os valores encontrados foram referenciados por $\mathrm{kWh}$ tendo como base os volumes de emissões atmosféricas na Tabela 4.4 que estão atrelados ao valor de referência $1 \mathrm{t}_{\text {alcóol. }}$. Em suma, os valores a serem apresentados a seguir estão associados às emissões calculadas para o valor de referência supracitado;

- os valores encontrados, servem apenas para uma avaliação inicial quantitativa até mesmo para efeito de comparações de primeira ordem em relação aos valores encontrados para a fonte biomassa de outros países; Isso ocorre, pois nesta simulação não se utilizou dados meteorológicos para a simulação (a aplicação disponível na internet não tem esse parâmetro de entrada, sendo utilizados os valores padrões estipulados pelo Projeto ExternE) e tão pouco funções dose-resposta ajustadas à realidade brasileira; e,

- foram utilizados os valores de emissão para o ciclo completo, levando em conta o que metodologia do projeto ExternE prevê (complete fuel cycle). Neste caso, conforme já indicado por Ometto (2005), 32,68 \% dos impactos avaliados correspondem à etapa de geração de eletricidade. Os principais resultados são apresentados a seguir: 
Tabela 6.5. Valoração das externalidades relacionadas com o efeito estufa.

\begin{tabular}{lrr}
\hline \multicolumn{3}{c}{ Efeito Estufa - 1 euro $=\mathbf{R} \$ \mathbf{2 , 7 9 4 1 4}$} \\
\hline Participação por tipo de substância & $\boldsymbol{\epsilon} / \mathbf{k W h}$ & $\mathbf{R} \mathbf{~ / ~} \mathbf{k W h}$ \\
\hline $\mathrm{CO}_{2}$ & 0,25 & 0,699 \\
$\mathrm{CH}_{4}$ & 0,0179 & 0,050 \\
$\mathrm{~N}_{2} \mathrm{O}$ & 0,0169 & 0,047 \\
Total & 0,2848 & 0,796 \\
\hline
\end{tabular}

A maior contribuição nos custos externos relacionados ao efeito estufa ocorre devido às emissões de dióxido de carbono, majoritariamente atreladas ao consumo de combustíveis fósseis, em especial diesel, na utilização dos equipamentos e maquinários agrícolas bem como no transporte de passageiros (vans e ônibus) e materiais (caminhões), conforme pode ser visto na Tabela 6.5.

Tabela 6.6. Valoração das externalidades por categoria de impacto.

\begin{tabular}{|c|c|c|}
\hline \multicolumn{3}{|c|}{ Resumo da poluição atmosférica - 1 euro $=R \$ 2,79414$} \\
\hline Categoria de Impacto & $€$-cent / kWh & $\mathbf{R S} / \mathbf{k W h}$ \\
\hline Saúde Humana & 18,11 & 0,506 \\
\hline Materiais & 0,06 & 0,002 \\
\hline Total & 18,17 & 0,508 \\
\hline
\end{tabular}

De acordo com a Tabela 6.6., a categoria de impacto com participação mais significante é a relacionada com a saúde humana. A categoria de impacto que envolve plantações foi desconsiderada, pois seus resultados estavam abaixo da terceira casa decimal.

Tabela 6.7. Valoração das externalidades por substância emitida.

\begin{tabular}{lr}
\hline $\begin{array}{c}\text { Poluição atmosférica } \\
\text { humana }\end{array}$ & $-\begin{array}{r}\text { Resultados à saúde } \\
\text { Substância }\end{array}$ \\
\hline \multicolumn{2}{c}{ Soh } \\
\hline$O_{3}$ & 0,27 \\
$P M$ & 0,19 \\
Sulfato & 0,02 \\
Nitrato & 0,02 \\
Total & 0,51 \\
\hline
\end{tabular}


Avaliando os resultados à saúde humana por substância, as que apresentam os maiores custos associados são o ozônio e as emissões de particulados.

Os principais impactos e efeitos avaliados na etapa qualitativa deste trabalho e com base nos métodos de avaliação de impactos no ciclo produtivo da cana elaborados por Ometto (2005) foram ratificadas com as estimativas apresentadas via simulação computacional.

\section{ATIVIDADE 7 - FERTIRRIGAÇÃO}

Nesta atividade, a fertirrigação da vinhaça ocorre por gravidade e por aspersão, sendo o transporte da torta de filtro feito por caminhão. Considerou-se que a quantidade de vinhaça utilizada é a mesma que sai da produção do álcool bem como o volume de torta de filtro. $\mathrm{Na}$ estimativa da quantidade de nutrientes adicionais em uso, Ometto (2005) utilizou como referência os dados de Macedo et al. (2004). Com relação ao consumo de diesel e as distâncias percorridas, utilizou-se uma média ponderada do consumo dos tratores pela velocidade média (para determinada potência).

Avaliando as emissões atmosféricas apresentadas pelo método EDIP e sumarizadas na Tabela 4.4., observa-se que as emissões correspondentes a esta etapa tem uma participação semelhante aos resultados encontrados nas atividades do ciclo agrícola (atividades 1, 2 e 3) e correspondem, majoritariamente, ao consumo de combustíveis fósseis (diesel) seguido das emissões provenientes da aplicação de fertilizante, o que inclui as emissões provenientes da cadeia do fertilizante fosfatado $-\mathrm{P}_{2} \mathrm{O}_{5}$.

No que se refere ao consumo de recursos não renováveis (Tabela 4.8.), a atividade 7 se destaca nos resultados pelo uso de agroquímicos nesta fase com participação, também, da utilização do diesel. Conforme a Tabela 4.7., que trata do consumo de recursos renováveis, o consumo apresentado se deve à utilização da própria vinhaça, da torta de filtro e de água, além da incorporação destes recursos provenientes da cadeia do fertilizante fosfatado.

Comparativamente com as atividades do ciclo agrícola, o potencial de aquecimento global (Tabela 4.10.) apresenta um resultado três vezes superior ao da atividade 1, devido ao consumo de combustíveis fósseis. Do mesmo modo, como é evidenciado na Tabela 4.9. a 
energia consumida tem a mesma origem (diesel) além do consumo energético proveniente da absorção da cadeia do fertilizante fosfatado.

Com relação ao potencial de eutrofização (Tabela 4.13.) a atividade 7 é a que apresenta o resultado mais expressivo para este indicador em relação à todas as outras atividades envolvidas no ciclo produtivo da cana-de-açúcar justamente por envolver a questão da incorporação dos nutrientes ao solo. Pelos resultados apontados pelo método EDIP conforme aponta a Tabela 4.12., o potencial de acidificação desta etapa é baixíssimo. Na avaliação do potencial de formação de ozônio troposférico os resultados apresentados na Tabela 4.11. são praticamente nulos.

Não foi apresentado potencial de ecotoxicidade crônica (Tabela 4.14.) ao solo e água na avaliação desta atividade. Com relação à toxicidade humana (Tabela 4.15.), a via aérea é a que apresenta maior potencial, sendo aproximadamente da mesma magnitude deste mesmo potencial na atividade 1 associados, principalmente ao uso de combustíveis fósseis.

O despejo de vinhoto nos rios, afluentes e solos afetando de forma indireta também a qualidade da água dos lençóis freáticos foi uma prática extremamente crítica no início do Proálcool. Atualmente, a vinhaça transformou-se numa vantagem econômico-ambiental para o produtor de cana, sendo agora devolvido ao solo como fertilizante, em quantidades controladas visando não contaminar os lençóis freáticos, trazendo retorno na produtividade por hectare e no prolongamento do ciclo da cana (Melo e Silva, 2004).

Segundo Melo e Silva (2004), a vinhaça é um resíduo ácido que, lançado nos corpos hídricos é capaz de dizimar os seres da microfauna e microflora, que formam os plânctons dos rios, afugentando, inclusive, a fauna marítima, ameaçando a preservação e manutenção de algumas espécies. Outra característica apontada pelos mesmos autores é que devido ao aumento da poluição advinda da vinhaça há, como um efeito da poluição em questão, um aumento da população de pernilongos e insetos que podem servir como vetores para propagação de doenças endêmicas.

Tanto é verdade, que se encontrou em grande parte das licenças ambientais expedidas pelo órgão ambiental e apresentadas nos documentos de concepção de projeto MDL condicionantes relativas ao monitoramento (físico-químico e biológico) da qualidade da água (subterrânea e superficial) em pontos internos à área da usina e ao redor da planta. 
Esta preocupação é relevante se adicionarmos a informação apresentada pela figura abaixo, onde é possível notar que a presença das áreas de cultivo de cana-de-açúcar apresentam interferência com uma quantidade considerável de rios e, provavelmente com os demais corpos hídricos vinculados à estes nas bacias hidrográficas que compõem o estado (03 bacias).

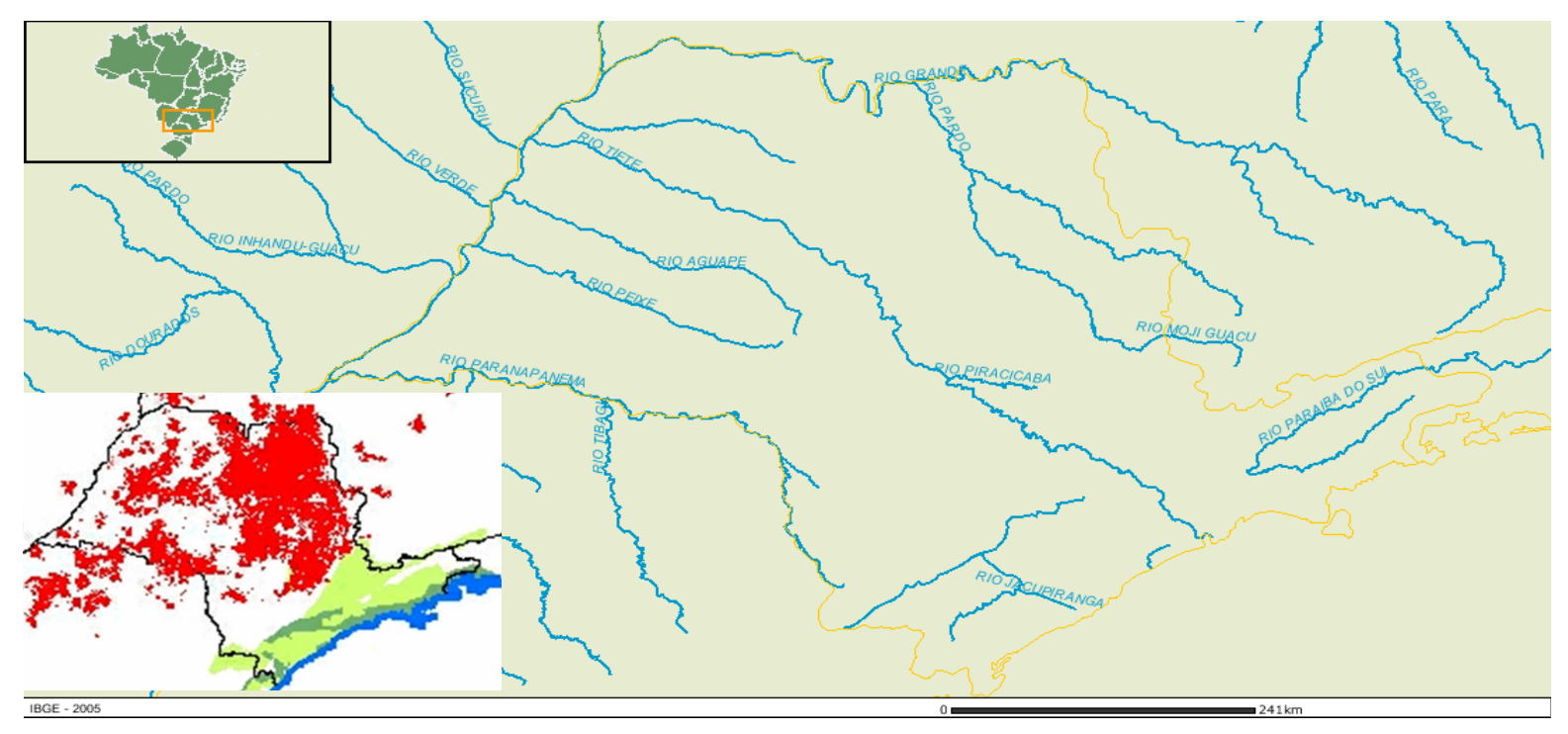

Figura 6.1. Mapa resumido da hidrografia do Estado de São Paulo ${ }^{68}$. Fonte: (IBGE, 2007) e (Lucon, 2004) Adaptado Legenda: Linhas azuis: Rios

O evento de descarte da vinhaça em cursos d'água, se ainda fosse considerada como prática no setor sucroalcooleiro seria considerada como uma externalidade negativa cuja alocação seria regional e local afetando tanto o meio biótico que interage com o recurso hídrico quanto aos seres humanos que dela dependessem direta ou indiretamente. Contudo, hoje, a prática atual é o uso da vinhaça para fertirrigação de forma controlada, motivada principalmente por ações de controle e pelos benefícios econômicos.

Com isto em mente, deve-se avaliar se o benefício advindo da utilização deste resíduo dentro do próprio ciclo produtivo pode ser ou não considerado como uma externalidade positiva. Visto que o agente beneficiado é o próprio agente gerador do resíduo. De fato, apenas observando a destinação de um resíduo de uma forma que ele gere benefícios econômicos ao usineiro, não pode ser considerada uma externalidade positiva. Contudo, o fato da utilização da vinhaça reduzir o consumo por fertilizantes e agroquímicos nas etapas produtivas do ciclo agrícola da cana diante até mesmo dos resultados apresentados nas atividades 1, 2 e 3 o que

\footnotetext{
${ }^{68}$ As áreas vermelhas localizadas no canto esquerdo da figura complementar (Lucon, 2004) representam as regiões de cultivo da cana.
} 
representa um benefício ao meio biótico e de quem os usufrui, conclui-se que ela representa um benefício caracterizando uma externalidade positiva.

Conforme já apresentado em capítulo específico, a geração de energia com o uso da vinhaça também traz consigo benefícios externos e é considerada como uma externalidade positiva.

Tabela 6.8. Externalidades levantadas na atividade 7 .

\begin{tabular}{|c|c|c|c|}
\hline $\begin{array}{c}\text { Externalidade } \\
\text { positiva }\end{array}$ & Agente Externo & Efeito Externo & $\begin{array}{c}\text { Custo Externo } \\
\text { Envolvido } \\
\end{array}$ \\
\hline $\begin{array}{l}\text { Redução no } \\
\text { uso de } \\
\text { fertilizantes e } \\
\text { agroquímicos }\end{array}$ & $\begin{array}{l}\text { - recursos hídricos; } \\
\text { - meio biótico; }\end{array}$ & $\begin{array}{l}\text { A não exposição ou } \\
\text { susceptibilidade à } \\
\text { contaminação ou } \\
\text { exposição acima do } \\
\text { permitido. } \\
\text { Alocação: local e/ou } \\
\text { regional; }\end{array}$ & $\begin{array}{l}\text { - redução nos } \\
\text { custos com } \\
\text { fertilizantes e } \\
\text { agroquímicos; } \\
\text { - aumento da } \\
\text { produtividade } \\
\text { agrícola/ }\end{array}$ \\
\hline $\begin{array}{c}\text { Geração de } \\
\text { eletricidade } \\
\text { pela utilização } \\
\text { da vinhaça }\end{array}$ & $\begin{array}{l}\text { - população e o meio ambiente; } \\
\text { - concessionárias de } \\
\text { distribuição de energia e } \\
\text { comercializadoras de energia } \\
\text { elétrica; }\end{array}$ & $\begin{array}{l}\text { - redução na emissão } \\
\text { de gases de efeito } \\
\text { estufa; } \\
\text { - deslocamento de } \\
\text { energia proveniente } \\
\text { de combustíveis } \\
\text { fósseis; } \\
\text { - serviço de energia: } \\
\text { economia de escopo } \\
\text { (energia gerada sob } \\
\text { as formas térmica e } \\
\text { elétrica sendo que o } \\
\text { excedente é } \\
\text { comercializado) ao } \\
\text { invés de economia de } \\
\text { escala (geração } \\
\text { centralizada); } \\
\text { - auxilia na } \\
\text { equalização da carga } \\
\text { pelo distribuidor } \\
\text { local; }\end{array}$ & $\begin{array}{l}\text { - mitigação dos } \\
\text { custos } \\
\text { decorrentes do } \\
\text { efeito estufa; } \\
\text { - remuneração via } \\
\text { comercialização } \\
\text { de créditos de } \\
\text { carbonos; }\end{array}$ \\
\hline & & Alocação: global & \\
\hline
\end{tabular}


Segundo Melo e Silva (2004), os custos para a renovação do canavial variam entre 10,9 e $20,87 \%$ a menos para a cana fertirrigada. Desta redução, aproximadamente 87,2 \% ocorre pela redução dos gastos com os fertilizantes. Os autores também indicam um ganho superior a $30 \%$ com o desenrolar das socas, o que constitui um ganho na produtividade.

\subsection{EXTERNALIDADES - OUTROS ASPECTOS NO SETOR SUCROALCOOLEIRO}

A fim de complementar as externalidades já apresentadas a partir dos métodos de avaliação de impactos no ciclo produtivo da cana, partiu-se da premissa que o meio ambiente, num sentido amplo, pode ser dividido em: meio físico (ar, água, solo); meio biótico (fauna, flora, etc ...); e, meio socioeconômico (aspectos sociais, de saúde,e econômicos).

\subsubsection{EXTERNALIDADES ASSOCIADAS AO MEIO BIÓTICO}

A avaliação dos efeitos externos aos ecossistemas e biodiversidade são exemplos de processos cuja avaliação é complexa, pois envolve dinâmicas que ainda precisam ser estudadas com maior profundidade e consenso científico para, num segundo momento, surgir o detalhamento quantitativo. De fato, analisar as perdas na biodiversidade devido às externalidades da geração de energia e as demais atividades do ciclo produtivo da cana como, por exemplo, as emissões de $\mathrm{NO}_{\mathrm{x}}$ e o uso da terra em diferentes tipos de habitats o que resulta em respostas diferenciadas pelos biomas envolvidos é algo que carece de estudos específicos, sendo apenas encontrado, dentre a bibliografia pesquisada, nos estudos realizados pelo projeto ExternE.

Do levantamento bibliográfico, os estudos do ExternE (EC, 2005) são os que apresentam algumas análises com relação às externalidades nos ecossistemas. As maiores dificuldades apontadas são a falta de dados e a convergência do meio acadêmico com relação aos métodos. Os efeitos avaliados por este estudo são o de eutrofização e acidificação com base na capacidade de suporte máximo do meio. A questão da fauna não é abordada apesar de existir a possibilidade de sofrer efeitos, como por exemplo, aumento de mortalidade ou alterações nos ciclos reprodutivos e demais desdobramento sobre a dinâmica dos habitats e dos próprios 
biomas. As duas figuras abaixo, que contém os mapas das faunas ameaçadas de extinção, ilustram a preocupação supracitada.

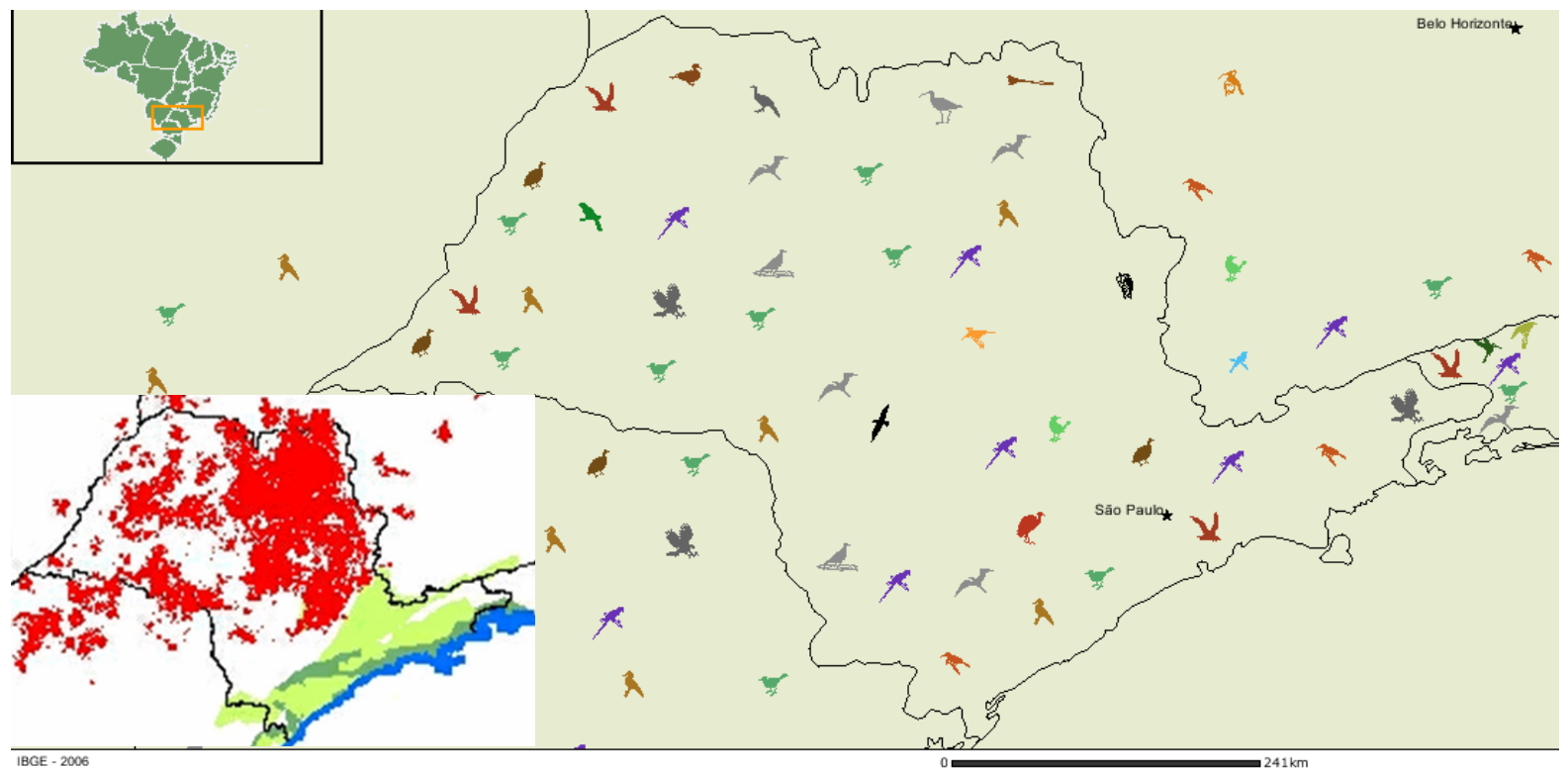

Figura 6.2. Mapa de fauna ameaçada de extinção - específico de aves - do Estado de São Paulo ${ }^{69}$. Fonte: (IBGE, 2007) e (Lucon, 2004) Adaptado

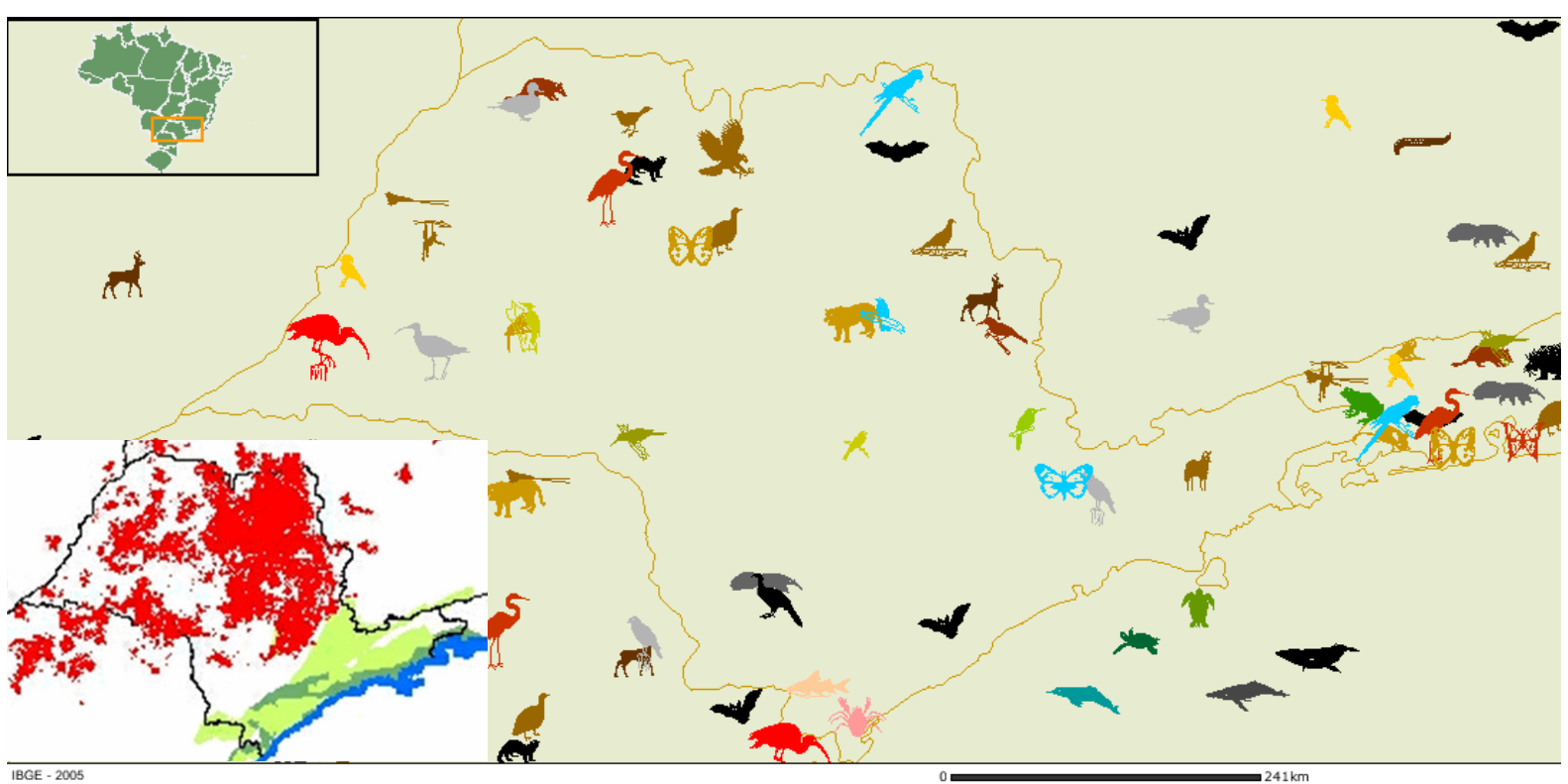

Figura 6.3. Mapa de fauna ameaçada de extinção - contendo demais animais - do Estado de São Paulo.

Fonte: (IBGE, 2007) e (Lucon, 2004) Adaptado

\footnotetext{
${ }^{69}$ Optou-se por não apresentar as legendas, pois o objetivo destas figuras é qualitativo. As áreas vermelhas localizadas no canto esquerdo da figura complementar (Lucon, 2004) representam as regiões de cultivo da cana.
} 
Não objetivando esgotar o assunto, a seguir são apresentados algumas informações com relação ao setor sucroalcooleiro e o meio biótico, visando apontar - se houver, mesmo que qualitativamente, as externalidades envolvidas.

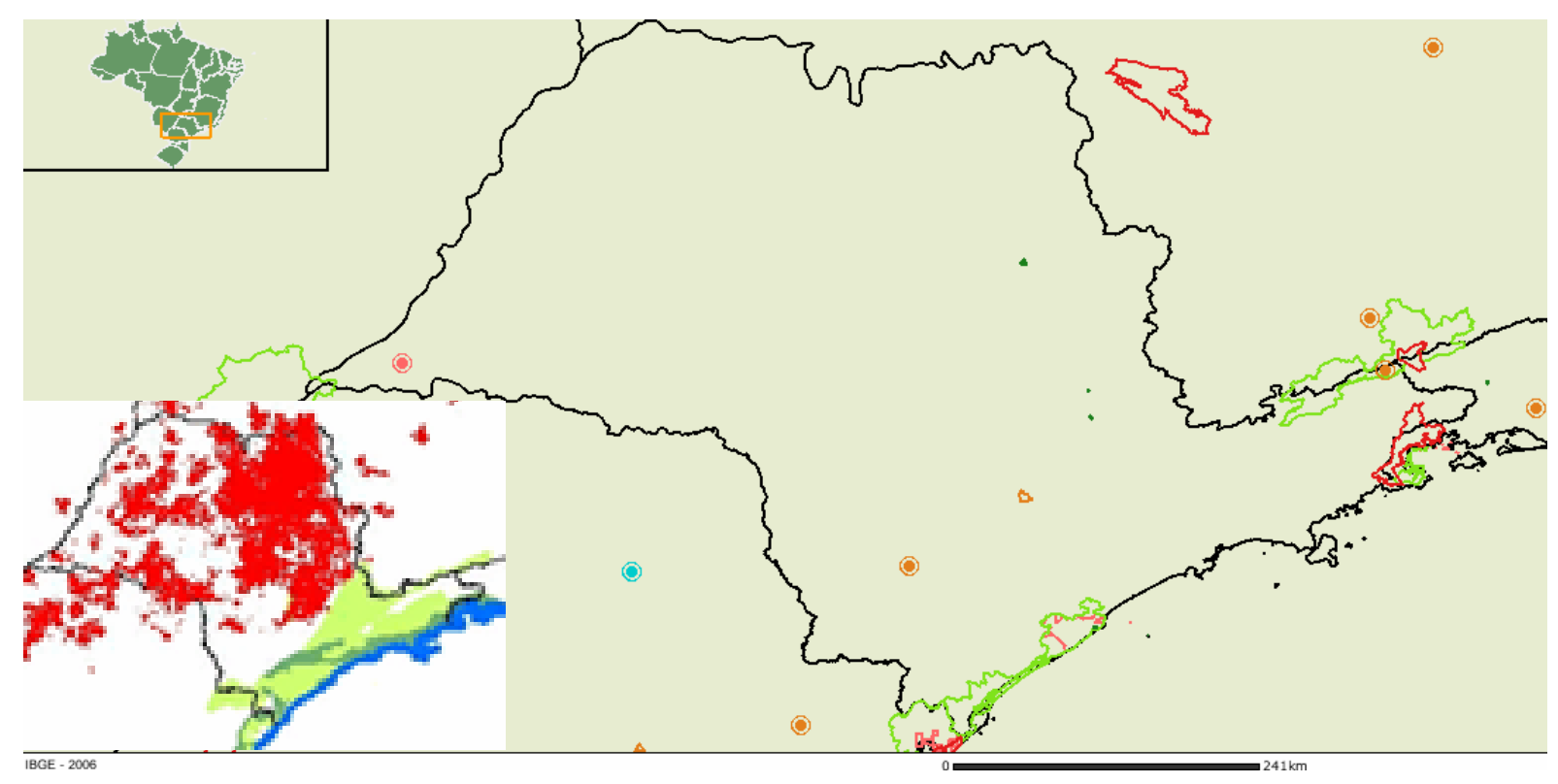

Figura 6.4. Áreas de preservação e interesse ambiental dentro do Estado de São Paulo ${ }^{70}$. Fonte: (IBGE, 2007) e (Lucon, 2004) Adaptado

Destaca-se que o principal bioma de maior preocupação no Estado de São Paulo é o referente à Mata Atlântica recentemente considerada como patrimônio nacional pela Lei $N^{o} 11.428$, de 22 de dezembro de 2006. Contudo, o bioma que apresenta a maior ocupação pela atividade da cana-de-açúcar e que possui poucas áreas de conservação, preservação e interesse ambiental é o cerrado, como é apresentado na próxima figura.

O cerrado está localizado principalmente na região centro-norte do Estado de São Paulo, interrompido por outras formações vegetais, como nas proximidades de Campinas, Ribeirão Preto, Franca e Altinópolis. Foram localizadas as principais atividades desenvolvidas nessas áreas de cerrado do Estado (SMA, 1997):

- Franca, Araraquara, Ribeirão Preto e São Carlos: pasto, cana, reflorestamento, culturas temporárias e citros;

- Jales, Fernandópolis e Votuporanga: pasto e culturas temporárias;

\footnotetext{
${ }^{70}$ Os locais onde se apresentam pontos são áreas de interesse e importância ambiental que ainda não foram delimitadas. As áreas delimitadas pela linha verde são referentes ao bioma mata atlântica.
} 
- Assis, Ourinhos e Marília: pasto, culturas temporárias e cana

- Araçatuba: pasto e cana

- Pirassununga e Leme: cana, citros e reflorestamento;

- Baurú: pasto, cana e reflorestamento; e,

- Botucatu: reflorestamento e cana.

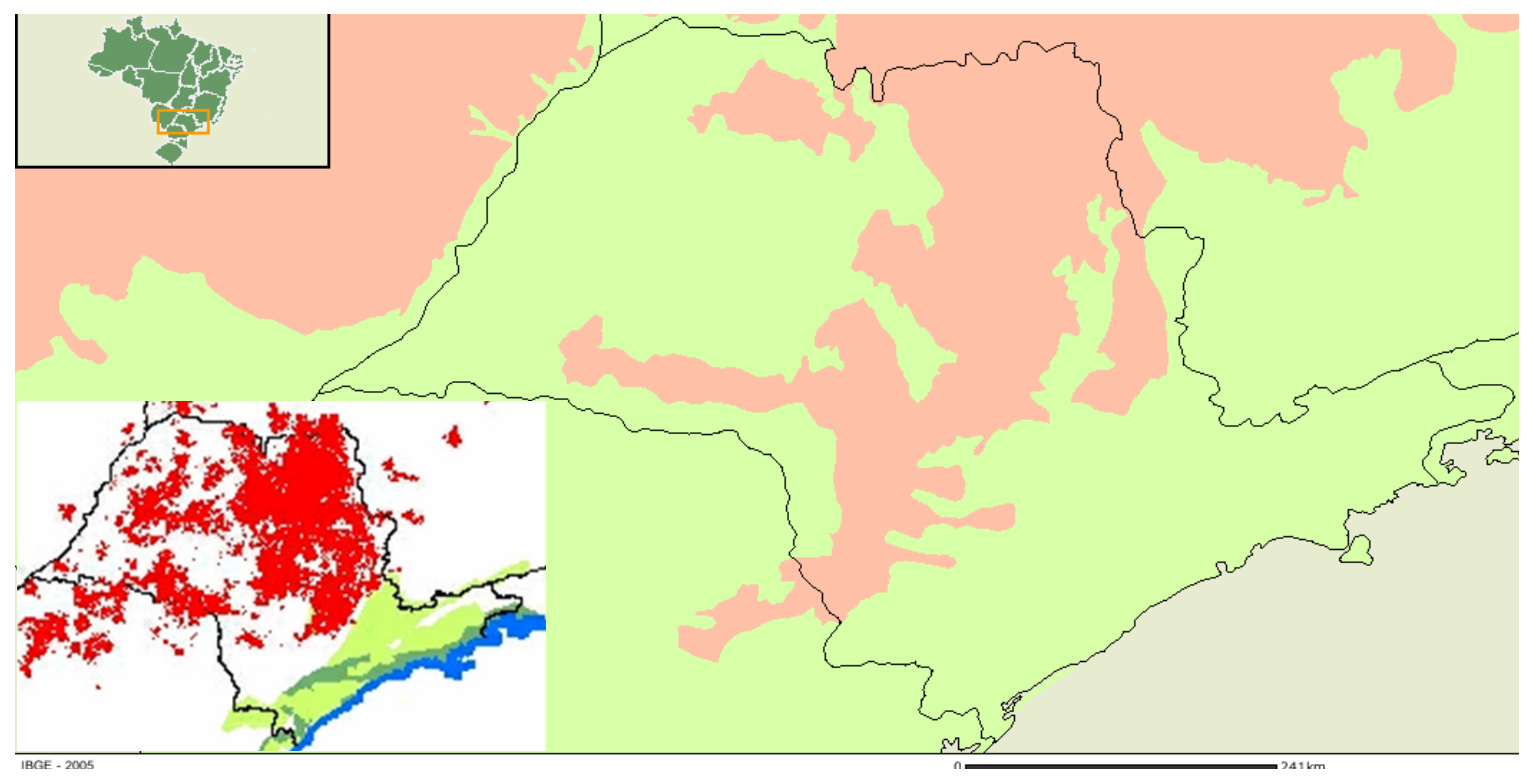

Figura 6.5. Biomas do Estado de São Paulo. Fonte: (IBGE, 2007) e (Lucon, 2004) Adaptado Legenda: Verde: Mata Atlântica - Rosa: Cerrado

Da vegetação dos cerrados que originalmente cobriam o território paulista, cerca de $14 \%$, resta apenas $1 \%$ espalhado em inúmeros fragmentos. Menos de $10 \%$ dessa vegetação estão inseridos nas unidades de conservação estaduais e o restante se localiza em propriedades rurais particulares, em processo de conservação espontânea, fato que fragiliza a situação dos remanescentes (Panzutti, 2003).

Com base nos processos de pedidos de autorização de supressão de vegetação encaminhados ao Departamento Estadual de Proteção aos Recursos Naturais (DEPRN), da Secretaria Estadual do Meio Ambiente (SMA), no período de 1996 a 2001, Panzutti (2003) constata que foram analisados 128 pedidos de supressão da vegetação do cerrado, vindos de Barretos, Rio Claro, Presidente Prudente, Sorocaba, Botucatu, Franca, Avaré, São João da Boa vista, Ribeirão Preto, Baurú, São Carlos e São José do Rio Preto. E que a maioria dos pedidos de supressão da vegetação correspondem à atividade da pecuária, que totalizou 4.148 hectares, 
aproximadamente $39 \%$ da área total. Em seguida, as solicitações para o cultivo de laranjas e de loteamentos urbanos ou rurais com 2.417 ha, foram as mais solicitaram áreas de supressão. Atividades agrícolas como a cana-de-açúcar e a soja mostraram participação mais discreta, segundo a autora. Dos processos analisados, $63 \%$ obtiveram parecer favorável para a supressão.

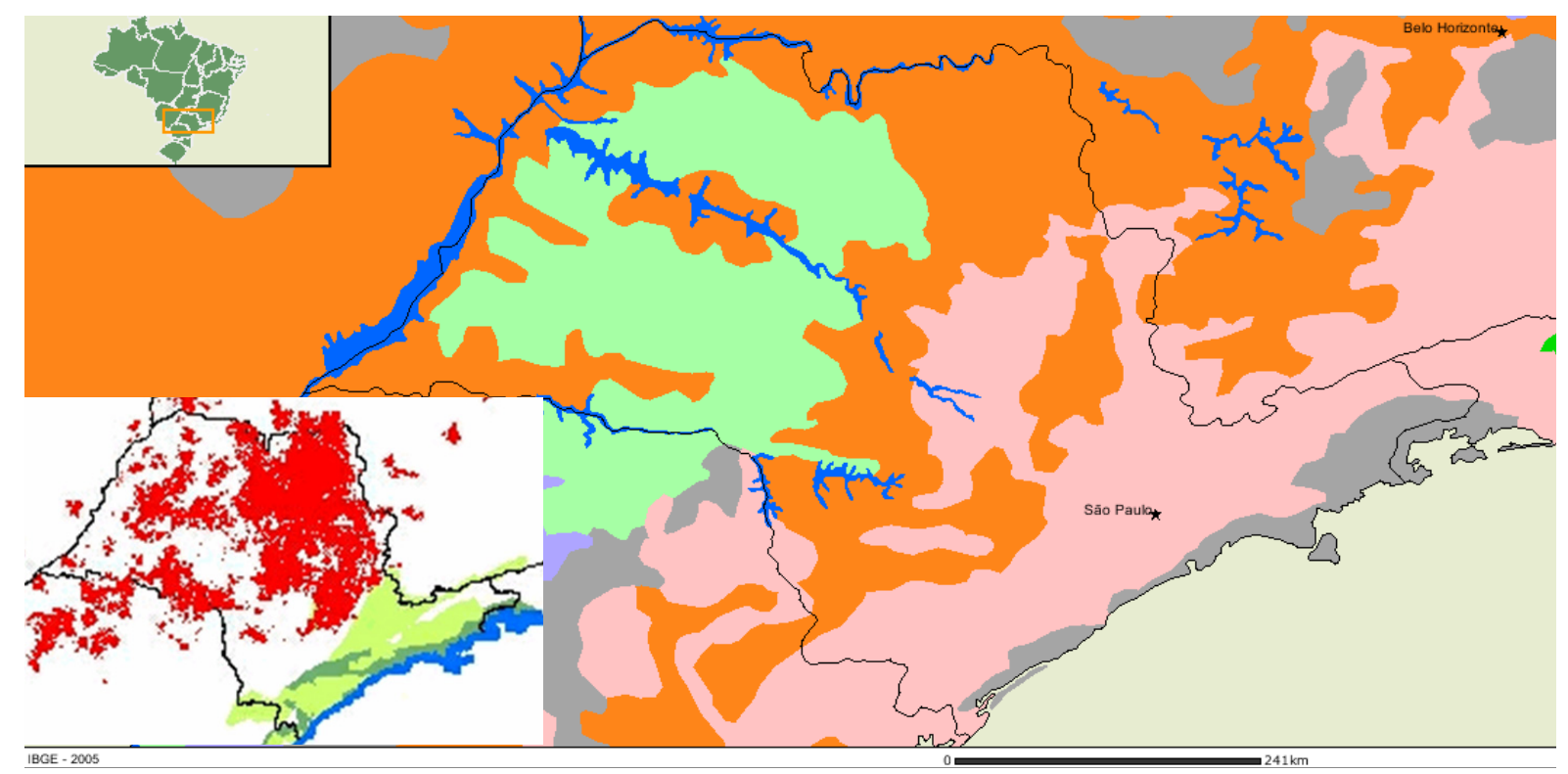

Figura 6.6. Mapa do potencial agrícola do Estado de São Paulo. Fonte: (IBGE, 2007) e (Lucon, 2004)

Adaptado Legenda: Cinza: Desfavorável - Rosa: Restrito; Laranja: Regular - Verde: Boa

Da figura acima, percebe-se que o cultivo da cana predomina em regiões consideradas como boas e regulares pelo levantamento do IBGE e que ainda existem regiões com potenciais agrícolas com capacidade para absorver este cultivo.

Com relação a esta dissertação e aos resultados encontrados, destacam-se as externalidades associadas ao meio físico que poderão intervir no comportamento dos biomas dependendo da sua localização em relação às áreas de cultivo da cana-de-açúcar e das suas unidades industriais principalmente, devido ao fato de existirem externalidades cujo critério de alocação é regional e local.

A expansão da atividade canavieira pode ser vista como uma externalidade negativa se, considerada a situação de que o setor sucroalcooleiro pode vir a pressionar outras formas de agronegócio, impulsionando indiretamente novas expansões de áreas de cultivo agrícola, agropastoris ou agroindustriais. Conforme visto acima, as áreas de pastagem vêm apresentando grande participação nas solicitações de supressão das áreas de cerrado no 
Estado. Tal fato se agrava, pois o cerrado normalmente se desenvolve em terras de fertilidade baixa a média, requerendo então o uso de adubos e agroquímicos, um dos impactos negativos do ciclo produtivo da cana.

Para Migliacci (2007), as preocupações quanto ao desflorestamento são exageradas, pois não será preciso desmatar regiões nativas por existirem áreas de pastagens disponíveis no Estado de São Paulo para absorver o cultivo da cana. Cultivo este que, atualmente, ocupa cerca de seis milhões de hectares no país, isto é, menos de $1 \%$ da terra agrícola do Brasil.. Além disso, o autor complementa:

“... não seriam precisos mais que $5 \%$ dessas terras para atingir o nível de produção imaginado para daqui a 10 anos..."

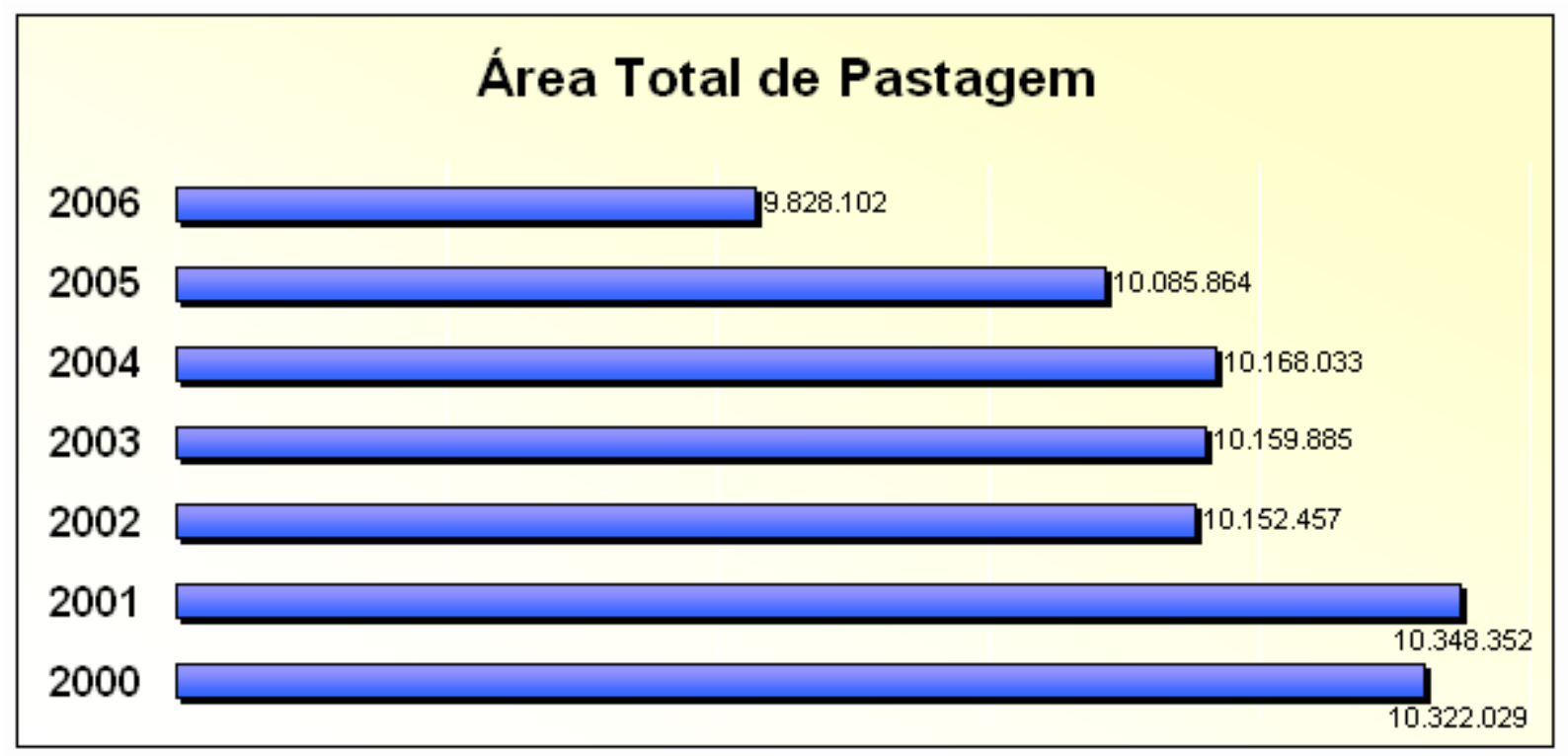

Figura 6.7. Área total de pastagem. Período: 2000 - 2006. Fonte (IEA, 2006)

De acordo com a figura acima, o Estado de São Paulo possui, para o ano de 2006, uma área de 9,928 milhões de hectares de pastagem, uma queda de 2,55 \% em relação ao ano anterior. No entanto, a queda na área de pastagem era esperada, devido aos problemas na exportação de carne e ao baixo preço do leite, que tornaram a atividade menos competitiva em relação a outras atividades em plena expansão de área, como cana-de-açúcar e eucalipto (IEA, 2006).

Segundo IEA (2007), a expansão da cana-de-açúcar nesta última safra 2005/2006, no Estado de São Paulo, ficou registrada 15,9 \% superior a área total plantada da safra anterior, atingindo a marca de 4,25 milhões de hectares. São 585 mil hectares de cana a mais 
comparada com a safra 2004/2005. A produção obteve um crescimento de $11,8 \%$ em relação à safra anterior. A situação das regiões no Estado demonstra o crescimento do cultivo da cana na sua totalidade, com destaque para as áreas que tradicionalmente não são canavieiras. Por exemplo, municípios da regional de Botucatu onde se registra 21 mil hectares em áreas novas de cultivo e outros 60 mil em produção, São José do Rio Preto com 60 mil hectares com plantação de cana a partir desta safra e outros 98 mil em produção. Municípios na região de Avaré, tradicionais produtores de feijão e milho, registram 17 mil hectares de cana e outros 28 mil hectares já em produção. Presidente Prudente vem apresentando aumento de área há várias safras e atingiu nesta última 38 mil hectares de área nova.

Em suma, a expansão da área de cultivo da cana-de-açúcar não só tem absorvido áreas de pastagem como, também, outras produções consideradas tradicionais no Estado tais como feijão e milho já citados anteriormente e, observando com mais atenção as áreas citadas pelo IEA (2007): a região de Botucatu onde a principal atividade é a avicultura (frango); São José do Rio Preto cujas principais atividades são avicultura (frango) e produção de laranja; Presidente Prudente onde a principal atividade é a bovina (corte). De modo que a afirmativa de Migliacci (2007) deve ser considerada com ressalvas, pois diante do exposto cerca de 100 mil novos hectares que antes possuíam outras atividades agrícolas, agora foram absorvidas pela atividade canavieira nesta última safra evidenciando que as áreas de pasto possuem participação na expansão da cultura de cana, conforme evidenciado pelo IEA (2006), mas não respondem completamente pela área expandida. 


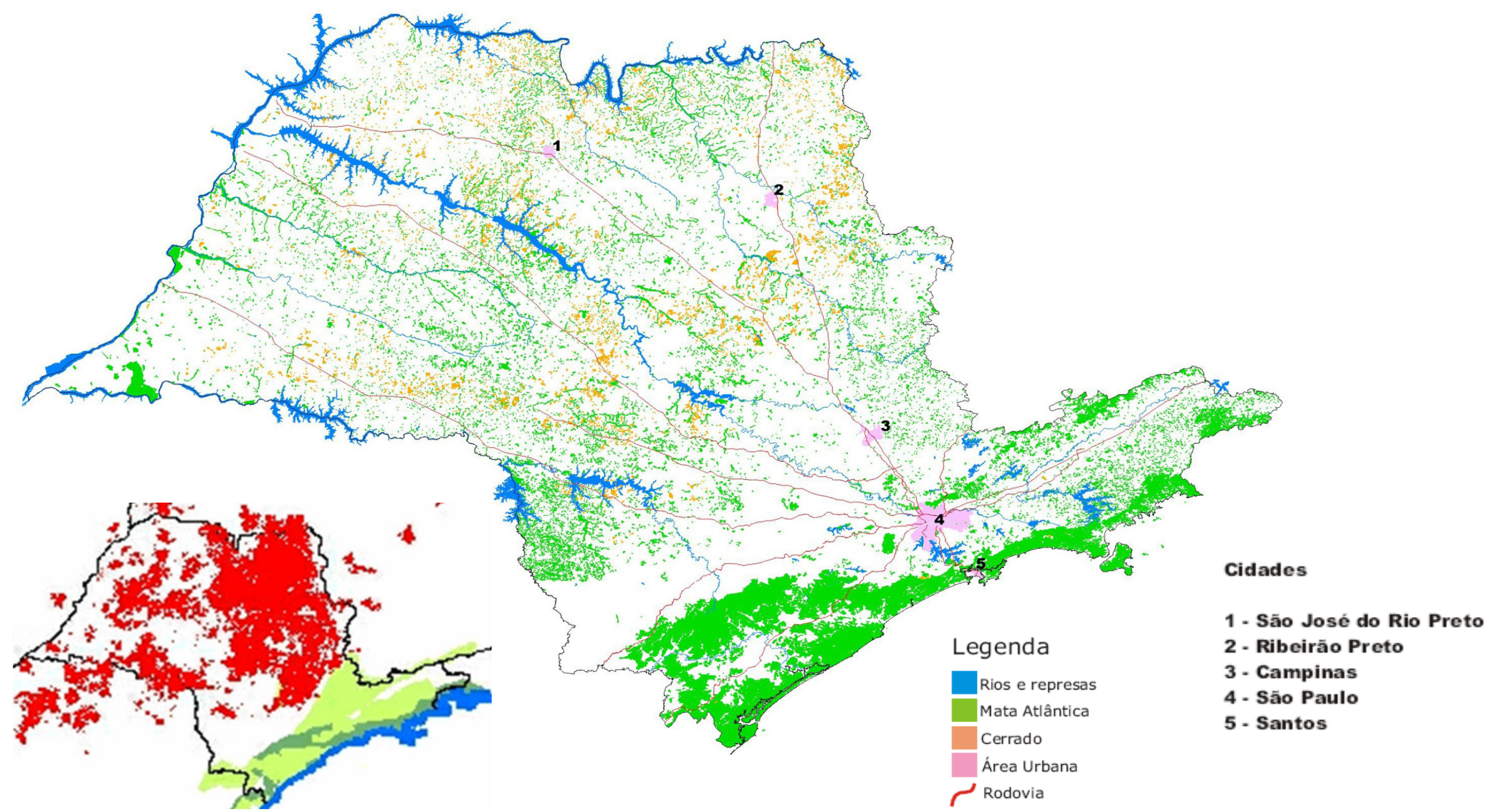

Figura 6.8. Mapa dos remanescentes florestais do Estado de São Paulo. Fonte: (IF, 2007), (Lucon, 2004) Adaptado 
No entanto, a informação da figura acima gera uma expectativa quanto à quantificação desta externalidade devido à grande quantidade de pequenos fragmentos existentes de mata atlântica e cerrado que coexistem com as áreas de cultivo de cana de açúcar indicadas por Lucon (2004). Infelizmente, nota-se que grande parte da área do Estado de São Paulo encontra-se antropizada, salvo as áreas costeiras e de preservação da mata atlântica.

Diante disto, um posicionamento claro, definitivo e quantitativo sobre o assunto, merece uma análise mais detalhada e aprofundada por estudos específicos com equipes multidisciplinares na área com bons conhecimentos dos biomas envolvidos e das características presentes ao meio biótico do Estado de São Paulo.

Para Lucon (2004), os impactos no meio biótico pela atividade do setor sucroalcooleiro, estão relacionados com:

- Alteração da cobertura vegetal;

- Alteração da dinâmica populacional das comunidades faunísticas, em virtude da alteração de hábitats;

- Perda de diversidade biológica pela implantação de monocultura.

De forma complementar aos itens apresentados acima, numa análise de primeira ordem, considera-se que a atividade produtiva da cana de açúcar pode ser vista como uma externalidade negativa e de âmbito regional/local considerando, também os itens:

- a premissa do mecanismo indireto de pressão sobre outras atividades agrícolas;

- incremento no consumo de agroquímicos nas regiões onde houver expansão de áreas que pertencem ao bioma cerrado;

- a existência de condicionantes ambientais nas licenças de operação das usinas relativas, principalmente, à recuperação ou recomposição de áreas degradas;

- os efeitos das emissões e possíveis efeitos físicos sobre os habitats expostos aos efeitos físicos da atividade produtiva da cana. 
Destas considerações, apenas a última se aplica especificamente à geração de energia elétrica, sendo que a primeira opção só pode ser considerada se a geração de energia fosse o principal produto do setor, o que não é o caso.

Inclusive, com relação ao último item, dependendo do agente ativo que atuar negativamente neste meio, pode ser avaliado a adoção de tecnologias que visem reduzir ou até mesmo eliminar estes agentes já na fonte emissora.

Contudo, segundo Macedo (2005) já se encontra em discussão a recomposição de matas ciliares (não somente em áreas de cana) pelo seu benefício ambiental e com a possível obtenção de recursos via MDL objetivando auxiliar nos custos inerentes à recomposição. Estimativas recentes, para uma área de 700 mil ha de áreas de cana no Estado de São Paulo, indicam que cerca de $8 \%$ delas correspondem a áreas de área de preservação permanente APP relativas a matas ciliares.

\subsubsection{EXTERNALIDADES ASSOCIADAS AO MEIO FÍSICO}

Para Lucon (2004), os principais impactos da atividade do setor sucroalcooleiro associados ao meio físico e que se encontram dispersos em cada uma das atividades já analisadas, são:

- Redução da disponibilidade hídrica, decorrente da captação superficial;

- Processos erosivos e conseqüente assoreamento dos corpos d'água superficiais;

- Riscos de contaminação do solo e dos recursos hídricos, pelo uso de fertilizantes e defensivos agrícolas;

- Risco de contaminação do solo, devido à disposição inadequada de efluente líquido (vinhaça);

- Poluição atmosférica: queima da cana na colheita, queima de bagaço nas caldeiras, aumento de circulação de veículos automotores;

Com relação a este meio, não foram verificadas outras externalidades além das apresentadas com base na avaliação de impactos discutidos por Ometto (2005). 


\subsubsection{EXTERNALIDADES ASSOCIADAS AO MEIO SOCIOECONÔMICO}

A análise apresentada a seguir, não visa esgotar o assunto, principalmente devido à complexidade e a multidisciplinaridade envolvida neste tipo de avaliação. No entanto, alguns efeitos externos e sugestões de redução dos mesmos são apresentados.

Para Lucon (2004), os impactos no meio biótico pela atividade do setor sucroalcooleiro, estão relacionados com:

- Sazonalidade da mão-de-obra;

- Incremento no tráfego viário;

- Alteração de uso e ocupação do solo (substituição de culturas);

- Aumento da pressão sobre a infra-estrutura urbana dos municípios sob influência do empreendimento.

Dos itens apresentados, são considerados como pertinentes para análise de externalidades o aumento da pressão sobre a infra-estrutura urbana dos municípios sob influência dos empreendimentos sucroalcooleiros.

Como já foi discutida em outro capítulo, a questão da sazonalidade e a redução de postos de trabalho devido à mecanização, não podem ser considerados como externalidades vistos que estão diretamente atreladas à atividade produtiva. No entanto, o fato de haver ociosidade e um incremento nos índices de desemprego desta mão de obra, pode ser encarado como uma externalidade negativa tanto na escassez quanto na sobre oferta de empregos quando vistos pela ótica do último item apresentado por Lucon (2004).

De fato, essa pressão existe nos momentos:

- de sobre oferta de empregos: alterando a dinâmica local e até mesmo regional do fluxo de migração de pessoas com interesse nestes postos de trabalhos sazonais (principalmente para as atividades 1, 2, 3 e 4); e,

- de escassez e redução dos postos de trabalho: alterando o sentido do fluxo na migração de pessoas objetivando a procura de locais onde existam vagas a serem preenchidas. 
No entanto, para ambos os casos, mesmo diante de um fluxo migratório, sempre existem os profissionais que optam por se fixar numa dada localidade trazendo consigo a família. Nestes casos, também há uma pressão sobre a infra-estrutura urbana dos municípios, pois estes indivíduos buscam sobrevivência no mercado informal e sobrecarregam os sistemas locais de assistência, além de, em alguns casos, possibilitar a promoção de ocupações desordenadas no espaço urbano.

Por exemplo, tendo como referência as informações prestadas nos documentos de concepção de projetos MDL para as usinas citadas a seguir, no que tange a questão de geração de empregos, as seguintes informações são prestadas: na Usina Serra, são 540 empregos diretos e 850 empregos sazonais; Usina Coruipe, 4.300 empregos diretos e 21.500 empregos indiretos; Usina Equipav, indica que 3.800 posições são influenciadas indiretamente nos municípios mais próximos pela atividade da usina; Usina Santa Cândida, 2.900 empregos diretos e 980 empregos indiretos. Casos interessantes são apresentados pela Usina Lucélia, onde existem 1.850 empregos num município de 18,000 habitantes, cerca de $10 \%$ da população do município, comparando-se quantitativamente; e, por fim, a Usina Colombo que gera 3.829 empregos diretos e estima 4.000 empregos indiretos onde a localidade de Colombo possui 7.500 pessoas.

Muitos desses projetos apresentam projetos de contrapartida assistencial, incluindo assistência média, odontológica, subsídios para taxa escolar e auxílio na medicação. Estes benefícios são estendidos, em alguns casos, para as posições ditas sazonais visando minimizar o impacto dessa pressão sobre os municípios na infra-estrutura básica (saúde, educação, transporte ...).

Contudo, para Gonçalves (2002) com o aumento da mecanização na lavoura, com a adoção da colheita da cana crua, uma grande massa de trabalhadoras está sendo dispensada em todas as regiões canavieiras do Estado de São Paulo. A sazonal idade na contratação de trabalhadores está se invertendo nas usinas; a entressafra tem-se tornado o período de maior contratação de mão-de-obra, nas regiões canavieiras, em função do plantio da cana. Contudo, esse cenário ainda não é realidade nas áreas de topografia acidentada, tamanho reduzido ou declividade superior a recomendada tecnicamente e, por enquanto, estas usinas poderão manter o volume de empregos sazonais atrelados às etapas agrícolas do ciclo da cana.' 
Tabela 6.9. Reflexos da mudança para o sistema de colheita de cana crua sobre as principais regiões canavieiras do Estado de São Paulo (Gonçalves, 2003 pg. 85 - Dados coletados pelo autor em jan/fev 2000).

\begin{tabular}{|c|c|c|}
\hline $\begin{array}{l}\text { Região } \\
\text { Agricola }\end{array}$ & $\begin{array}{c}\text { Classificação } \\
\text { do Sistema }\end{array}$ & Principais características observadas \\
\hline Limeira & promissor & $\begin{array}{l}\text { com restrições climáticas, desemprego acentuado, há programas sociais } \\
\text { específicos, não há terceirização na colheita, fornecedores com } \\
\text { dificuldades para adaptação }\end{array}$ \\
\hline Piracicaba & $\begin{array}{c}\text { pouco } \\
\text { promissor }\end{array}$ & $\begin{array}{l}\text { restrições topográficas, desemprego atinge mais trabalhadores imigrantes, } \\
\text { fornecedores passam por dificuldades para adaptação, não há } \\
\text { terceirização da colheita e algumas empresas estudam deixar a região. } \\
\text { sem restrições climáticas ou topográficas, desemprego predomina }\end{array}$ \\
\hline Araraquara & promissor & $\begin{array}{l}\text { trabalhadores migrantes, pequena terceirização da colheita, poucos } \\
\text { programas sociais; }\end{array}$ \\
\hline Sorocaba & $\begin{array}{c}\text { pouco } \\
\text { promissor }\end{array}$ & cultura de cana em declínio, predominância de trabalhadores migrantes, \\
\hline Jaú & $\begin{array}{l}\text { pouco } \\
\text { promissor }\end{array}$ & $\begin{array}{l}\text { sérias restrições climáticas, desemprego preocupantes, situação dos } \\
\text { fornecedores instável, reduzida terceirização na colheita, há poucos } \\
\text { programas sociais }\end{array}$ \\
\hline $\begin{array}{l}\text { Ribeirão } \\
\text { Preto }\end{array}$ & $\begin{array}{l}\text { muito } \\
\text { promissor }\end{array}$ & $\begin{array}{l}\text { não há restrições climáticas ou topográficas, desemprego preocupantes, } \\
\text { fornecedores apreensivos, baixa terceirização da colheita é crescente, há } \\
\text { poucos programas sociais }\end{array}$ \\
\hline Orlândia & $\begin{array}{l}\text { muito } \\
\text { promissor }\end{array}$ & $\begin{array}{l}\text { não há restrições climáticas ou topográficas, desemprego preocupantes, } \\
\text { fornecedores apreensivos, não há terceirização da colheita, há programas } \\
\text { sociais específicos }\end{array}$ \\
\hline Catanduva & $\begin{array}{l}\text { muito } \\
\text { promissor }\end{array}$ & $\begin{array}{l}\text { não há restrições climáticas ou topográficas, pouco desemprego, pouco } \\
\text { afeta os fornecedores, não há programas sociais específicos nem } \\
\text { terceirização da colheita. }\end{array}$ \\
\hline Lins & $\begin{array}{l}\text { muito } \\
\text { promissor }\end{array}$ & $\begin{array}{l}\text { não há restrições climáticas ou topográficas, desemprego preocupante, } \\
\text { fornecedores satisfeitos, há terceirização da colheita e programas sociais } \\
\text { específicos }\end{array}$ \\
\hline Andradina & $\begin{array}{l}\text { muito } \\
\text { promissor }\end{array}$ & $\begin{array}{l}\text { não há restrições climáticas ou topográficas, desemprego preocupante, } \\
\text { fornecedores satisfeitos, há terceirização da colheita e programas sociais } \\
\text { específicos }\end{array}$ \\
\hline Assis & $\begin{array}{c}\text { pouco } \\
\text { promissor }\end{array}$ & $\begin{array}{l}\text { há apenas restrições climáticas, desemprego preocupante, fornecedores } \\
\text { insatisfeitos, não há terceirização da colheita e há poucos programas } \\
\text { sociais }\end{array}$ \\
\hline
\end{tabular}

Diante do exposto acima, considera-se que a atividade produtiva da cana de açúcar na fase agrícola pode ser vista como uma externalidade negativa e de âmbito regional/local sob os aspectos socioeconômicos.

Como contrapartida, visando minimizar os problemas que esta temática impõe, dá-se a sugestão de se compartilhar as responsabilidades entre Estado, sociedade e os empreendedores. Com a adoção de projetos regionais garantindo requalificação e renda às famílias de trabalhadores e agricultores excluídos pela tecnologia no campo. O projeto deve visar integrar as aptidões culturais de cada região com o objetivo de melhorar o quadro existente de fluxo de pessoas vs. empregos. 
Estas aptidões culturais são facilmente vistas conforme as informações apresentadas a seguir.

Segundo Danadelli et al (1999) no Estado de São Paulo os produtos que são os mais representativos do setor produtivo agroindustrial são: a cana-de-açúcar, carne bovina, carne de frango, laranja para indústria, café beneficiado e ovo, representando, em conjunto, 64,87 \% do valor da produção deste setor na economia paulista. Os resultados encontrados com base na contribuição percentual no valor da produção paulista apontam a seguinte distribuição: canade-açúcar com a maior participação do setor, com 28,21\%; seguida pela carne bovina, com $10,30 \%$; carne de frango, 7,91\%; laranja para indústria, 6,40\%; café beneficiado, $6,20 \%$ e, por fim, ovo, com 5,85\%.

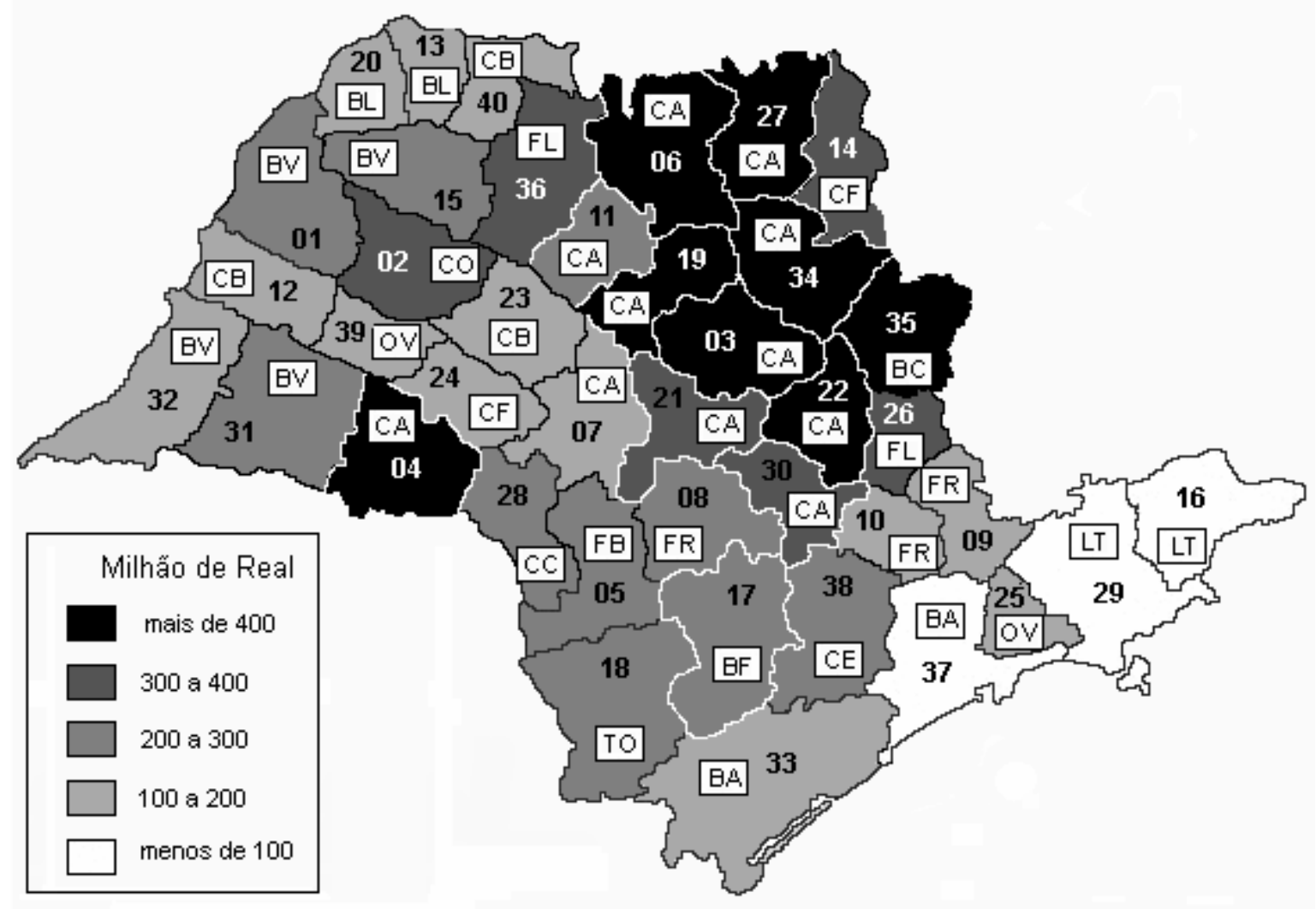

\begin{tabular}{ll|ll}
\hline \multicolumn{2}{l|}{ Escritórios de Desenvolvimento Rural (EDRs) } & \multicolumn{2}{l}{ Produtos Agropecuários } \\
\hline 01 - Andradina & 21 - Jaú & BA & Banana \\
$02-$ Araçatuba & 22 - Limeira & BC & Batata + café \\
$03-$ Araraquara & 23 - Lins & BF & Batata + feijão \\
$04-$ Assis & 24 - Marília & BL & Carne + leite \\
& & & continua ...
\end{tabular}


continua

\begin{tabular}{|c|c|c|c|}
\hline \multicolumn{2}{|c|}{ Escritórios de Desenvolvimento Rural (EDRs) } & \multicolumn{2}{|c|}{ Produtos Agropecuários } \\
\hline 05 - Avaré & 25 - Moji das Cruzes & BV & Carne bovina \\
\hline 06 - Barretos & 26 - Mogi Mirim & $\mathrm{CA}$ & Cana-de-açúcar \\
\hline 07 - Bauru & 27 - Orlândia & $\mathrm{CB}$ & $\begin{array}{l}\text { Cana-de-açúcar }+ \\
\text { carne bovina }\end{array}$ \\
\hline 08 - Botucatu & 28 - Ourinhos & $\mathrm{CC}$ & $\begin{array}{l}\text { Cana-de-açúcar + } \\
\text { café }\end{array}$ \\
\hline $\begin{array}{l}09 \text { - Bragança } \\
\text { Paulista }\end{array}$ & 29 - Pindamonhangaba & $\mathrm{CE}$ & Cebola \\
\hline 10 - Campinas & 30 - Piracicaba & $\mathrm{CF}$ & Café \\
\hline 11 - Catanduva & 31 - Presidente Prudente & $\mathrm{CO}$ & $\begin{array}{l}\text { Cana-de-açúcar + } \\
\text { ovos }\end{array}$ \\
\hline 12 - Dracena & 32 - Presidente Venceslau & CS & $\begin{array}{l}\text { Cana-de-açúcar + } \\
\text { soja }\end{array}$ \\
\hline 13 - Fernadópolis & 33 - Registro & FB & $\begin{array}{l}\text { Feijão + carne } \\
\text { bovina }\end{array}$ \\
\hline 14 - Franca & 34 - Ribeirão Preto & FL & Frango + laranja \\
\hline $\begin{array}{l}15 \text { - General } \\
\text { Salgado }\end{array}$ & $\begin{array}{l}35 \text { - São João da Boa } \\
\text { Vista }\end{array}$ & FR & Frango \\
\hline 16 - Guaratinguetá & 36 - São José do Rio Preto & $\mathrm{LJ}$ & Laranja \\
\hline 17 - Itapetininga & 37 - São Paulo & $\mathrm{LT}$ & Leite \\
\hline 18 - Itapeva & 38 - Sorocaba & $\mathrm{OV}$ & Ovos \\
\hline 19- Jaboticabal & 39- Tupã & TO & Tomate \\
\hline 20 - Jales & 40 - Votuporanga & & \\
\hline
\end{tabular}

Figura 6.9. Classificação dos 40 Escritórios de Desenvolvimento Rural (EDRs), por Faixa de Valor de Produção e Classificação das Principais Atividades Agropecuárias nos EDRs, Estado de São Paulo. Fonte: Danadelli et al (1999) Modificado 


\section{CONCLUSÕES}

Este trabalho apresenta a avaliação das externalidades relativas ao ciclo produtivo da cana de açúcar, dando um enfoque para a questão da geração de energia elétrica. A avaliação foi elaborada com base em fontes secundárias, privilegiando-se, sempre que possível, os trabalhos que apresentam levantamentos de campo.

Esta dissertação contribui para a bibliografia já existente, pois agrega a análise das externalidades do ciclo produtivo da cana até a etapa de geração de eletricidade, métodos e práticas existentes e atuais sobre avaliação e quantificação dos custos externos bem como informações relativas às metodologias de quantificação dos fatores de emissão. Fatores estes essenciais para determinar o deslocamento de fontes energéticas que contribuam para o efeito estufa e que estejam conectados ao SIN. Neste contexto, utilizaram-se os métodos de análise e quantificação de impactos de ciclos produtivos (EDIP, exergia e emergia) empregados na avaliação das atividades produtivas.

Os objetivos principais deste estudo são realizar um levantamento e uma análise das externalidades sociais, ambientais e econômicas do ciclo produtivo da cana-de-açúcar desde sua fase inicial (período agrícola) até a conversão energética da biomassa em energia elétrica (objeto de ênfase nesse projeto). Repartindo os impactos, quando possível nos subsistemas elaborados a partir da análise do ciclo produtivo do setor, cujos resultados de uma forma geral eram até então conhecidos, mas nunca segregados e tratados de forma integrada sob a ótica de avaliação das externalidades relacionadas à atividade de produção. Os objetivos foram atingidos e os resultados permitiram o levantamento de algumas questões importantes, que podem levar ao desenvolvimento de novos estudos.

Cabe frizar que tanto a avaliação e quantificação das externalidades estimadas quanto à análise do ciclo de vida, apresentam limitações que, em suma, trazem consigo graus de incerteza em relação aos resultados.

No caso das externalidades, não somente pela forma de quantificação, mas pela incerteza que já nasce na concepção do método de avaliação. É uma tarefa difícil comparar resultados quantitativos de estudos que possuam o mesmo objeto pelo fato dos mesmos não 
apresentarem de forma explícita as incertezas de suas estimativas bem como as diferenças metodológicas nas abordagens.

Do mesmo modo, se reflete à análise do ciclo de vida, com questionamentos às seguintes definições: sistemas funcionais e unidade de referência estarem adequados; quais são as limitações na qualidade dos dados e na análise de sensibilidade; e, até que ponto se definem as margens dos sistemas.

A avaliação das externalidades na geração de energia está associada diretamente com os aspectos técnicos e tecnológicos dos processos de conversão de energia. Seja pela questão social, por exemplo, a adoção de tecnologias modulares, compactas e de fácil operação e manutenção gerando menos empregos que as técnicas convencionais; a questão ambiental, exemplificados pelos seguintes as aspectos: consumo de água diferenciada para ciclos térmicos de potência distintos; tecnologias de conversão da biomassa em eletricidade têm fatores de emissão atmosféricos variados alterando desta forma os impactos e efeitos externos relacionados a ela, tais como: a saúde humana e o meio biótico; e, por fim, a geração distribuída pode, numa escala representativa, alterar os investimentos no segmento de transmissão ou até mesmo de geração modificando a matriz de impactos externos na geração de eletricidade no médio prazo.

Considerando, ainda, a relação entre custos externos e as tecnologias de processo, a presente dissertação não ousou avaliar as externalidades envolvidas com outras rotas tecnológicas em pesquisa e desenvolvimento no setor sucroalcooleiro. De fato, isto ocorreu, pois o maior interesse é levantar e avaliar as externalidades existentes com as técnicas e métodos usuais, já difundidos e aplicados ao setor. Este tipo de avaliação cabe como sugestão para desenvolvimentos futuros.

Ao longo do trabalho destacou-se que o Estado de São Paulo é o maior produtor de cana-deaçúcar e seus produtos (açúcar / álcool) do país e, apresenta o maior potencial para aproveitamento das políticas de incentivo às fontes renováveis de energia, quando considerada a biomassa e, o deslocamento de energia térmica e elétrica implicando na possibilidade de inserção dentro de projetos MDL. A eletricidade excedente torna-se atraente quando considerada a complementaridade possível ao suprimento de eletricidade pelo parque gerador com base predominantemente hidráulica no SIN, dando relevância ao setor 
sucroalcooleiro na geração de eletricidade no país e no Estado. Outro aspecto relevante é a possível melhora nos índices de eficiência energética das unidades produtivas.

Com relação à participação na geração de energia elétrica do Brasil por unidade de federação, o Estado de São Paulo é o segundo maior gerador. Destacou-se que o setor sucroalcooleiro possui a maior participação na autogeração de eletricidade no Brasil, por setores da economia. Foi evidenciado, também, pelas séries históricas de produção e consumo de energia final, a relação de dependência energética do Estado com os aproveitamentos energéticos oriundos da cana-de-açúcar.

Com relação ao potencial do setor na mitigação da externalidade representada pelo efeito estufa, cuja alocação é global, o campo de atuação se apresenta vasto. Há a possibilidade do aproveitamento energético extra da biomassa da cana (além do tradicional uso do bagaço, o emprego de palhas e pontas) e até mesmo a possibilidade do uso da vinhaça para geração de energia. Representando, assim, um potencial extra em eletricidade excedente passível de ser comercializados e injetados no SIN e nos sistemas de subtransmissão ou de distribuição.

Ainda sobre a questão da vinhaça, seu uso como energético não implica na eliminação dos problemas que a cercam. Isto se torna claro quando se considera o projeto MDL apresentado anteriormente, onde nem toda a vinhaça é destinada ao processo de biodigestão e, além disso, o efluente final do processo ainda é destinado para fertirrigação, com a vantagem de possuir um impacto inferior ao da vinhaça in natura. Por outro lado, o uso da vinhaça como fertilizante é limitado ao tipo e a necessidade do solo, o que implica numa avaliação dos volumes recomendáveis para aplicação. Novos usos e destinações para este produto/subproduto tornam-se necessários, considerando os grandes volumes gerados em relação à produção de álcool. Alguns exemplos são: a Usina São João (Dedini) onde o metano extraído do processo de biodigestão é utilizado em veículos de transporte da Usina; Usina São Martinho cujo metano extraído é utilizado para secar leveduras.

Retornando à análise dos projetos MDL, destaca-se que, apenas quatro participavam do PROINFA dentre o conjunto de empreendimentos avaliados. As demais usinas apresentam contratos de PPA com as distribuidoras de energia elétrica. No capítulo 03 os fatos levantados apontam que pode ser mais interessante outras formas de empreender os excedentes de eletricidade além da opção do PROINFA, quando considerada a questão da remuneração dos créditos de carbono. 
Outra importante conclusão com relação ao MDL e o setor sucroalcooleiro estão atrelados às metodologias para quantificação dos fatores de emissão na rede elétrica. Isto ocorre, devido ao SIN e sistemas de subtransmissão e distribuição comportarem as usinas cogeradoras que utilizam o bagaço de cana-de-açúcar, da seguinte forma:

- Usinas integrantes ao PROINFA - a operação, intercâmbio entre subsistemas e otimização da operação do SIN são compatibilizados com a disponibilidade de eletricidade excedente conforme contrato de energia assinado entre o empreendedor (usineiro do setor sucroalcooleiro) e a ELETROBRAS. Em suma, a operação é realizada pelo ONS que possui como principal característica a operação centralizada do Sistema Elétrico Brasileiro (abrangendo geração e transmissão).

- Por outro lado, existem as usinas que estão conectadas diretamente ao sistema de distribuição ou subtransmissão e que possuem PPAs assinados com as distribuidoras de eletricidade. Nestes casos e, caracterizado o gerador como atividade de geração distribuída, a operacionalização entre a geração e à carga local do concessionário é de gestão dita descentralizada, isto é, é o próprio distribuidor que possui uma margem para compatibilizar a carga do seu sistema com a geração disponível.

Diante disso, nota-se que a metodologia apresentada, cabe para a situação onde há a operação centralizada, no caso brasileiro, pelo Operador Nacional do Sistema com a premissa do deslocamento de eletricidade advinda de combustíveis fósseis na margem.

No entanto, ainda é passível de discussões considerando a forma como a geração distribuída é tratada no planejamento de longos e médios prazos, sendo a geração abatida estaticamente da carga e o restante posto num ambiente de simulação dito dinâmico onde os ajustes da composição termo-hidráulica do parque gerador de eletricidade bem como dos limites de intercâmbio entre os subsistemas de transmissão são compatibilizados visando atender os requisitos técnicos e as demandas de carga do mercado mês a mês variando apenas os períodos de análise.

Considerando o excedente da cogeração gerido de forma descentralizada pelos distribuidores, a premissa apresentada pelas metodologias aprovadas pode não representar corretamente a operação do sistema, pois o distribuidor não poderá garantir sempre que estará deslocando na margem um parque gerador que contribua para as emissões do efeito estufa. Por fim, deixa-se a sugestão para o desenvolvimento de trabalhos futuros sobre a temática levantada. 
A amplitude das questões relacionadas às externalidades demanda a definição de um sistema que seja representativo nas etapas produtivas do setor, de forma a se obter uma área de estudo bem definida para avaliar os custos externos de interesse. A maior dificuldade encontrada para se desenvolver esta dissertação, inicialmente, residia na delimitação da área de abrangência do estudo. Inicialmente, pensou-se em analisar somente a etapa de geração de energia. Contudo, frente à disponibilidade de dados encontrados e da análise ampla de Ometto (2005), dos demais artigos científicos e dos PDDs do MDL que traziam consigo informações interessantes quanto à sustentabilidade, ações das usinas sob os aspectos ambientais e socioeconômicos bem como as licenças ambientais destes empreendimentos, optou-se pela análise do ciclo produtivo.

As licenças ambientais serviram como mecanismos indicativos das políticas de comando e controle, compensação e mitigação, pois proporcionam uma visão do que o Estado entende como variáveis importantes de serem monitoradas, fiscalizadas e preservadas.

O saldo da opção pela análise com base na avaliação do ciclo produtivo é considerado positivo, pois trouxe elementos extras à análise que antes não poderiam ser incluídos se a área de interesse do estudo fosse restrita somente à etapa de geração (energia térmica/elétrica). Como por exemplo, a questão das emissões na etapa de colheita da cana e seus desdobramentos sociais, a exergia perdida nesta fase e a recomendação de sua utilização no processo de geração de energia e o possível aproveitamento energético da vinhaça, são alguns deles.

A utilização da análise exergética por si só, não traz consigo grandes contribuições quando o objetivo é a avaliação das externalidades. Esta análise, em conjuntos com outras técnicas, como por exemplo, a avaliação de impactos no ciclo de vida (AICV) pode e deve complementar a avaliação e quantificação dos impactos. Mesmo assim, isto não significa que todos os custos externos inerentes a uma atividade produtiva estejam passíveis de serem analisados com a utilização restrita destas informações. Como um exemplo, convém mencionar que a análise com base na exergia e na AICV não carrega consigo a informação das dinâmicas socioeconômicas, por exemplo.

Pelo fato da Emergia assumir maior importância nos sistemas de hierarquia superiores enquanto as análises EDIP e exergética dão um maior peso aos componentes iniciais, nem todos os resultados da avaliação por emergia do ciclo de vida indicados por Ometto (2005) 
podem ser transpostos a realidade do presente estudo, onde o foco é o ciclo produtivo da cana sob a ótica da geração de eletricidade com o objetivo de subsidiar a avaliação das externalidades associadas a esta atividade. Isto se torna claro, em grande parte dos resultados obtidos via análise emergética, onde os maiores impactos estão atrelados às atividades de distribuição e uso final do etanol.

Portanto, para um melhor aproveitamento energético do ciclo de vida da cana-de-açúcar, indica-se a utilização da cana crua para o processamento industrial e o uso da palha para cogeração de energia, juntamente com o bagaço quando vistos da perspectiva dos métodos utilizados para avaliar o ciclo de vida: EDIP e Exergia.

Por fim, conclui-se que para a avaliação das externalidades, o método EDIP apresentou-se como o mais adequado seguido da análise exergética e emergética. A avaliação via exergia por apresentar um foco mais de otimização e minimização de perdas, pouco acrescenta à análise das externalidades neste estudo de caso. No entanto, a análise emergética, pode ser um importante método a ser utilizado em consonância com o EDIP na elaboração de um ACV objetivando alimentar uma análise de primeira ordem dos custos externos envolvidos na atividade produtiva. Como sugestão de continuidade deste trabalho, os seguintes desenvolvimentos futuros são apresentados:

- Avaliar os pontos onde há convergências e discrepâncias entre o método de avaliação e quantificação EDIP e outros tais como o Eco-indicator 99 e o CML 2001 quando aplicados ao setor sucroalcooleiro; e,

- Aplicar o método de avaliação emergética com ênfase na geração de eletricidade e associálo aos resultados existentes do EDIP, visando obter uma análise integrada.

Destaca-se que dos resultados encontrados nos Capítulos 4 e 6, dos impactos avaliados no ciclo produtivo da cana-de-açúcar, 32,68 \% correspondem à etapa de geração de eletricidade. Os principais impactos e efeitos avaliados na etapa qualitativa deste trabalho e com base nas externalidades da produção foram ratificadas como efeitos predominantes nas externalidades avaliadas presentes nas estimativas apresentadas via simulação computacional (ECOSENSE LE).

Os efeitos principalmente do Ozônio e da emissão de particulados necessitam de um maior detalhamento, no curto e médio prazo visando captar resultados sobre a saúde humana em 
pequenas janelas de exposição (dias) até longas janelas de exposição. Neste último caso, o interesse é na avaliação da cumulatividade deste evento, dos seus desdobramentos e dos desdobramentos sobre o aparelho assistencial à saúde do Estado.

As externalidades sobre o meio socioeconômico aparecem como uma importante componente que carece ser investigada com maior detalhamento, por envolver dinâmicas de migração de pessoas e famílias entre as regiões do Estado de São Paulo bem como envolve a avaliação das infra-estruturas existentes que darão suporte, ou não ao fluxo associado.

O mecanismo de desenvolvimento limpo pode ser visto como uma forma de internalização dos custos e efeitos externos relativos ao efeito estufa. Isto é comprovado pelo ExternE (2005) quando comparou os custos dos danos evitados com os preços dos certificados de redução de emissão e das permissões transacionadas entre países Anexo I na mesma época.

Com relação à avaliação de externalidades associadas ao meio biótico, as seguintes sugestões para trabalhos futuros são apresentadas:

- fomentar pesquisas visando avaliar os desdobramentos dos impactos relativos ao meio físico no biótico com o uso de indicadores de conservação e degradação, tamanho e estado de conservação da flora e fauna do habitat avaliado;

- levantamento da área de expansão da cana, visando detectar se houve algum tipo de supressão de vegetação nativa na área, se não, quais eram as atividades anteriores e estudar a dinâmica entre as atividades do setor agrícola procurando avaliar se realmente há uma forma de pressão da cultura canavieira dentro do Estado, forçando a expansão de outras áreas agrícolas, contribuindo para o cenário agudo de antropização apresentado pelo mapa de vegetação do Estado de São Paulo extraído do IBGE (2007) e evidenciado também pelo mapa de remanescentes apresentado pelo IF (2007);

- proposição de políticas efetivas e cabíveis em prol da conservação e melhoria das atuais condições do bioma do cerrado, já que a mata atlântica possui um instrumento legal que a considera como patrimônio nacional;

A geração de eletricidade excedente traz consigo externalidades positivas e negativas. Elas envolvem aspectos prejudiciais sob a ótica das emissões atmosféricas sobre a saúde humana e meio biótico; e, principalmente positiva - mediante a utilização de fontes renováveis para geração de eletricidade; deslocamento de combustíveis fósseis tanto no uso de energia térmica 
quanto de elétrica, reduzindo assim o consumo de derivados de petróleo que são um dos principais componentes fomentadores do efeito estufa; além dos benefícios associados à geração distribuída, também já discutidos neste trabalho.

Devido à multidisciplinaridade do assunto, temas de diferentes áreas tais como saúde, meio ambiente e socioeconomia tiveram sugestões para desenvolvimento de trabalhos visando, sobretudo, que os resultados deste conjunto subsidiem novas análises mais refinadas sobre as externalidades associadas a este ciclo produtivo.

As externalidades associadas à geração de energia elétrica, na maioria dos casos, apresentam uma categoria de dano dominante na estimativa do custo. E isto foi visto na prática, com os resultados apresentados pelo método de avaliação do ExternE, onde os efeitos à saúde humana decorrentes da categoria de impacto emissões atmosféricas, predominaram em relação aos demais efeitos. Esta observação pode facilitar o uso dos estudos de avaliação de externalidades no processo de tomada de decisão tanto para a proposição de políticas públicas quanto para a atividade de regulação do setor energético. 


\section{REFERÊNCIAS BIBLIOGRÁFICAS}

ABNT - Associação Brasileira de Normas Técnicas. NBR ISO 14040 Gestão Ambiental Avaliação do ciclo de vida - Princípios e estrutura. Brasil: ABNT. Novembro. 10p, 2001.

ABNT - Associação Brasileira de Normas Técnicas. NBR ISO 14041 Gestão Ambiental Avaliação do ciclo de vida - Definição do objetivo e escopo e análise de inventário. Brasil: ABNT. Maio. 25p., 2004.

Andrade, M. Espaço e tempo na agroindústria canavieira de Pernambuco. São Paulo, Estudos Avançados, Vol. 15, No. 43, Setembro/Dezembro 2001.

ANEEL - Agencia Nacional de Energia Elétrica - Banco de Informações de Geração. http://www.aneel.gov.br/aplicacoes/capacidadebrasil/OperacaoGeracaoTipo.asp?tipo=5\&ger= Combustivel\&principal=Biomassa , Novembro de 2006.

Arevalo, A. R. Poluição e defensivos em cana-de-açúcar. PLANALSUCAR, 1980.

Arnold F. Economic Analysis of Environmental Policy and Regulation. John Wiley \& Sons, Inc., 1995.

Barnthouse et al. Life-Cycle Impact Assessment: The State-of-the- Art. Report of the SETAC Life-Cycle Assessment (LCA) Impact Assessment Workgroup, SETAC LCA Advisory Group. Society of Environmental Toxicology and Chemistry (SETAC) and SETAC Foundation for Environmental Education Pendacola, FL, USA, 1997.

Bejan, A. Advanced Engineering Thermodynamics. John Wiley \& Sons, New York, N.Y, 1988.

Bejan, A.; Tsatsaronis, G.; Michael, M. Thermal Design and Optimization. WileyInterscience Publication, John Wiley \& Sons, USA \& Canada, 1996.

Bernow, S.; Marron, D. Valuation of Environmental Externalities for Energy Planning and Operations. Tellus Institute Report 90-SB01, 1990. 
Bernow, S.; Biewald, B.; Marron, D. Full-Cost Dispatch: Incorporating Environmental Externalities in Electric System Operation. The Electricity Journal, March: 20-33, 1991.

Bhattacharyya, S.C. An Estimation of Environmental Costs of Coal-Based Thermal Power Generation in India. International Journal of Energy Resources, 21: 289-298, 1997.

Bolognini, M. Externalidades na produção de açúcar e álcool combustível no Estado de São Paulo. Dissertação (Mestrado), PIPGE/USP, São Paulo, 1996.

Bosi, M. Fast-tracking small CDM projects: implications for the electricity Sector. OECD and IEA Information Paper, Paris, Outubro de 2001.

Braile, P. M.; Cavalcanti, J. Manual de Tratamento de Águas Residuárias Industriais. São Paulo, Companhia de Tecnologia de Saneamento Ambiental - CETESB, 1979.

Brighenti, C. Integração do cogerador de energia do setor sucroalcooleiro com o sistema elétrico. Dissertação (Mestrado) PIPGE/USP. São Paulo, 2003.

Brown, M.T; Harendeen, R.A. Embodied energy analysis and Emergy analysis: a comparative view. Ecological Economics, 19. p. 219-235, 1996.

Carlsen, A.J.; Strand, J.; Wenstøp, F. Implicit Environmental Costs in Hydroelectric Development: An Analysis of the Norwegian Master Plan for Water Resources. Journal of Environmental Economics and Management, 23: 201-211, 1993.

Camargo, C.A.; Ribeiro, A.M.; Souza, M.E.; Santos, N.F.; Conservação de energia na indústria do açúcar e do álcool. São Paulo, 1990.

Carpentieri, A.; Larson, E.; Woods, J. Future Biomass-Based Electricity Supply in Northeast Brazil. Biomass and Bioenergy, V.4, N.3, p.149-173.

Castro, O. M. Aspectos de manejo do solo. Fundação Cargill. $1^{\circ}$ Encontro do Uso da Terra na região do Vale do Paranapanema. São Paulo, 1985.

CCEE - Câmara de Comercialização de Energia Elétrica. Informações do website. http://www.ccee.org.br , Janeiro de 2007.

CENBIO - Centro Nacional de Referência em Biomassa. Levantamento do Potencial Real de Geração de Excedentes no Setor Sucroalcooleiro. São Paulo, 2001. 
Chernick, P.; Caverhill, E. The Valuation of Externalities from Energy Production, Delivery, and Use Fall. Boston: PLC, Inc., 1989.

Cifuentes, L.A.; Lave, L.B. Economic Valuation of Air Pollution Abatement: Benefits from Health Effects. Annual Review of Energy and the Environment, 18: 319-342, 1993.

Clarke E.H. Multipart pricing of public goods. Journal of Law and Economics 1: 1-44. College London and University of East Anglia.

Clementino, L. A conservação da energia por meio da co-geração de energia elétrica. Editora Érica, 9a Ed., Capítulo 02, p.19-32, São Paulo, 2004.

CETESB - Companhia de Tecnologia de Saneamento Ambiental. Nota sobre tecnologia de controle na fabricação de açúcar e álcool. Documento Técnico CETESB, 1985.

Coelho, S.T. A cana e a questão ambiental - aspectos sócio-ambientais da nova modalidade de energia. Workshop Bioeletricidade - a Segunda Revolução Energética da Cana-de-açúcar. INEE/BNDES/ELETROBRÁS, Rio de Janeiro, 2005.

Collins, D.; Odum, H.T. Calculating Transformities with an Eigenvector Method. Proceeding. Second Biennial Emergy Research Conference. Gainesville, FL, EUA, 2001.

Corbini, J. L. Operações agrícolas em tratos culturais. 1.ed. Campinas, Fundação Cargill, vol.1, p.333-370, 1987.

Cornelissen, R. L. Thermodynamics and Sustainable Development. Ph. D. Thesis. University of Twente, The Netherlands, 1997.

CPFL - Companhia Paulista de Força e Luz. Comercialização de Energia - Bioeletricidade e Vantagens da Associação. São Paulo, Novembro de 2005.

Cruz, R.L. Efeito da aplicação de vinhaça sobre o solo e água subterrânea. São Carlos. Tese (Doutorado) - Escola de Engenharia de São Carlos, Universidade de São Paulo, 1991.

Donadelli, A.; Coelho, P.J.; Santiago, A.N. Valor da produção agroindustrical do Estado de São Paulo. Instituto de Economia Agrícola, 1999.

EB - Executive Board, CDM. EB 08 - Annex 01 - Clarifications on issues relating to baseline and monitoring methodologies. 2003. 
EB - Executive Board, CDM. Bagasse-based cogeneration connected to an electricity grid AM0015. 2004

EB - EXECUTIVE BOARD, CDM. "Consolidated baseline methodology for grid-connected electricity generation from renewable sources" (ACM0002) - Revisão 06 de 19 de maio de 2006.

EB - Executive Board, CDM. Avoided methane emissions from organic waste-water treatment AM0013. Versão 03 de 19 de maio de 2006.

EB - Executive Board, CDM. Consolidated baseline methodology for grid-connected electricity generation from renewable sources ACM0002. Versão 03 de 19 de maio de 2006.

EB - Executive Board, CDM. Consolidated baseline methodology for grid-connected electricity generation from biomass residues ACM0006.Versão 03 de 19 de maio de 2006.

EC - European Commission. ExternE: Externalities of Energy (Vol. 1-6) Luxembourg: Office for Official Publications of the European Communities, 1995.

EC - European Commission. ExternE: Externalities of Energy (Vol. 7-10). Luxembourg: Office for Official Publications of the European Communities, 1999.

EC - European Commission. ExternE: Externalities of Energy - Methodology 2005 Update. Office for Official Publications of the European Communities, 2005.

Faaij, A., Meuleman, B.; Turkenburg, W.; Wijk, A.; Bauen, A.; Rosillo-Calle, F.; Hall, D. Externalities of Biomass Based Electricity Production. 1998.

Faccenda, O.; Souza L. A cogeração como alternativa no equacionamento da demanda de energia elétrica. Energia na Agricultura, São Paulo, Vol. 12, 33-45, 1995.

Fang, J.; Galen, P. Issues and methods in incorporating environmental externalities into the integrated resource planning process. National Renewable Energy Laboratory, 1994.

Furtado, R. The incorporation of environmental costs into electric power system planning in Brazil. Imperial College (Tese de Doutorado), Londres, 1996.

FIC. Teor do álcool hidratado combustível. São Paulo, 2004. 
FIESP - Federação das Indústrias do Estado de São Paulo. Ampliação da oferta de energia através da biomassa (bagaço de cana-deaçúcar).São Paulo,2001.

Freeman, A. M. Estimating the Environmental Costs of Electricity: An Overview and Review of the Issues. Resource and Energy Economics, 18: 347-362, 1996.

Freitas, G. R. Preparo do solo. In: Paranhos, S. B., coord. Cana-de-açúcar: cultivo e utilização. 1.ed. Campinas, Fundação Cargill. v.1, p.271-283, 1987.

Friedrich, R.; Kallenbach, U. External Costs of Electricity Generation. Berlin: SpringerVerlag, 1991.

Friedrich, R.; Voss, A. External Costs of Electricity Generation. Energy Policy, (February): 114-122, 1993.

Gonçalves, D.B. A regulamentação das queimadas e as mudanças nos canaviais paulistas. Ed. Rima, 2002.

Groves, T. Incentives in teams. Econometrica 41: 617-31.

Guterl, F. The return of Nuclear Power - Is na Oil-Hungry World Ready? Newsweek, pg 3039, Fevereiro de 2006.

Hall, D.C. Preliminary Estimates of Cumulative Private and External Costs of Energy. Contemporary Policy Issues, VII:. 282-307, 1990.

Hirschberg, S.; Jakob, M. Cost Structure of the Swiss Electricity Generation under Consideration of External Costs. Bern, 1999.

Hohmeyer, O. The Social Costs of Electricity - Renewables Versus Fossil and Nuclear Energy. International Journal of Solar Energy, 11: 231-250, 1992.

Hohmeyer, O. Social Costs of Energy Consumption. Berlin: Springer-Verlag, 1988.

Horen, C. Counting the Social Costs: Electricity and Externalities in South Africa. Cape Town: Élan Press and UCT Press, 1996.

IBGE - Instituto Brasileiro de Geografia e Estatística. Sistema de Mapas Temáticos do IBGE. 2007. 
IAC - Instituto Agronômico de Campinas. Estudo de Caso: Destilarias de álcool e usinas de açúcar. Campinas, Documentos Técnicos. IAC, n.49, 2004.

IEA - Instituto de Economia Agrícola. Produção Animal: Previsão No Estado De São Paulo Para 2006. Setembro, 2006.

IEA - Instituto de Economia Agrícola. http://www.iea.sp.gov.br Fevereiro, 2007.

IEA - International Energy Agency. World Energy Outlook. Paris: OECD Publications, 1998.

IEL/NC - Instituto Euvaldo Lodi; SEBRAE - Serviço Brasileiro de Apoio às Micro e Pequenas Empresas. O novo ciclo da cana - estudo sobre a competitividade do sistema agroindustrial da cana-de-açúcar e prospecção de novos empreendimentos. Brasília, 2005.

IF - Instituto Florestal. Projeto Biota/FAPESP. São Paulo, 2007.

IPCC. IPCC Good practice guidance and uncertainty management in National Green-house gas inventories. Volume 2 e 3, Módulo 1, 1996.

IPCC. IPCC Good Practice Guidance and Uncertainty Management in National Greenhouse Gas Inventories. Capitulos 2 e 6, 2000. Disponivel em: http://www.ipccnggip.iges.or.jp/public/gp/english/, Outubro de 2004.

IPCC. IPCC Guidelines for National Greenhouse Gas Inventories, Volume 2 e 3 Módulo 1, 1996. Disponível em: http://www.ipcc-nggip.iges.or.jp/public/gl/invs1.htm < Out de 2004>.

ISO - International Organization for Standardization. ISO 14042: Environmental Management - Life cycle assessment - Life cycle impact assessment. Geneva, CH: ISO, 2000.

Kotas, T.J.. The exergy method of thermal plant analysis. Reprint Edition. Florida, USA, Krieger Publishing Company. 328 p, 1995.

Krewitt, W. External Costs of Energy - Do the Answers Match the Questions? Looking back at 10 Years of ExternE. Energy Policy, 30: 839-848, 2002.

Kotas, T.J.. The exergy method of thermal plant analysis. Reprint Edition. Florida, USA, Krieger Publishing Company. 328 p, 1995. 
Leme, R.; Cunha, K.; Walter, A. Adicionalidade em projetos MDL e a cogeração no setor sucroalcooleiro brasileiro. AGRENER GD 2004 - 5o Encontro de Energia no Meio Rural e Geração Distribuída, 2004.

Lindahl, E. Just taxation - a positive solution. Classics in the Theory of Public Finance.

Lora, E.S. Controle da poluição do ar na indústria açúcareira. EFEI, 1998.

Lucon, O. Sustentabilidade e custos. Secretaria de Meio Ambiente do Estado de São Paulo, 2004.

Macedo, I. C. et al. Balanço das emissões de gases do efeito estufa na produção e no uso do etanol no Brasil. São Paulo: Governo do Estado de São Paulo, Secretaria do Maio Ambiente, 2004 .

Macedo, I.C. A produção de etano carburante e o Mecanismo de Desenvolvimento Limpo. XV Simpósio Nacional de Bioprocessos - SINAFERM, Recife, 2005.

Maddison, D. The Plausibility of the ExternE Estimates of the External Effects of Electricity Production. 1999.

Mankiw, R. Principles of Microeconomics. Prentice Hall International Inc., 2003.

Mas-Colell A.; Whinston M.; Green J. Microeconomic Theory. Oxford University Press, 1995.

MCT - Ministério da Ciência e Tecnologia. Relatório da produção do setor sucroalcooleiro. Brasília, 2003

MCT - Ministério de Ciência e Tecnologia. Status atual das atividades de projeto no âmbito do Mecanismo de Desenvolvimento Limpo (MDL) no Brasil e no mundo. Brasília, dezembro de 2006.

Melo, A.S.; Silva, M. Estimando o valor da externalidade positiva do uso da vinhaça na produção de cana-de-açúcar: um estudo de caso. ECOECO - Sociedade Brasileira de Economia Ecológica, São Paulo, 2004.

Mello, R. Custos ambientais de agroecossistemas da cana-de-açúcar. São Carlos. Tese (Doutorado) - Escola de Engenharia de São Carlos, Universidade de São Paulo, 1997. 
Migliacci, P.E. Produção de etanol pode ser desastre ecológico. National Geograpgic, Fevereiro de 2007.

Milleron, J. C. Theory of value with public goods: A survey article. Journal of Economic Theory 5: 419-77.

MME - Ministério de Minas e Energia. Disponível em: http://www.mme.gov.br/Proinfa/Texto_Programa.htm, Junho de 2004.

MME - Ministério de Minas e Energia. Balanço Energético Nacional - BEN. 2005.

MME - Ministério de Minas e Energia. Plano Decenal de Expansão de Energia Elétrica 2006 -2015. Maio de 2006.

Molnary, L. et. al., Projeto ExternE no Brasil, Divulgação e Cooperação Técnica, IPEN Instituo de Pesquisas Energéticas e Nucelares, 1999.

NAE - Núcleo de Assuntos Estratégicos da Presidência da República. Caderno NAE Mudança do Clima - Volume II - Mercado de Carbono. Pg. 161-226. Brasília, 2005.

Neto, F.; Dechen, S.; Conagin, A; Bertoni, J. Rotação de culturas: análise estatística de um experimento de longa duração em Campinas (SP). Bragantia v.61 n.2 Campinas maio/ago. 2002.

Neto, V. Análise da viabilidade da cogeração de energia elétrica em ciclo combinado com gaseificação da biomassa da cana-de-açúcar e gás natural. Dissertação (Mestrado), PPE/UFRJ, 2001.

Neto V. C. Geração de Energia elétrica com biomassa de cana-de-açúcar. Dissertação Programa de Planejamento Energético da COPPE/UFRJ, 2001.

Odum, H.T. Environmental Accounting, Emergy and Decision Making. New York: John Wiley. 370 p., 1996.

Oliveira, A.S. Posicionamento da cogeração no novo marco regulatório. Fórum de Cogeração, Rio de Janeiro, 2003.

Oliveira, A.S. Modalidades e procedimentos simplificados no mecanismo de desenvolvimento limpo. Alternativas Energéticas Sustentáveis no Brasil, Capítulo 5, página 377, 2004. 
Ometto, A. R. Discussão sobre os fatores ambientais impactados pelo setor sucroalcooleiro e a certificação socioambiental. São Carlos. Dissertação (Mestrado) - Escola de Engenharia de São Carlos, Universidade de São Paulo, 2000.

Ometto, A. R. Avaliação do ciclo de vida do álcool etílico hidratado combustível pelos métodos EDIP, Exergia e Emergia. São Carlos. Tese (Doutorado) - Escola de Engenharia de São Carlos, Universidade de São Paulo, 2005

ONS - Operador Nacional do Sistema Elétrico. Dados extraídos do website. http://www.ons.org.br, Setembro de 2006.

ORNL - Oak Ridge National Laboratory and Resources for the Future. External Costs and Benefits of Fuel Cycles (Reports 2-8). Washington: McGraw-Hill Utility Data Institute, 19941998.

OTA - Office of Technology Assessment - Congress of United States. Studies of Environmental Costs of Electricity. Setembro de 2004.

Ott, W. External Costs and External Price Addings in the Swiss Energy Sector. Berlin: Springer-Verlag, 1997.

Ottinger, R.L.; Hohmeyer O. Costs of Electric Power: Analysis and Internalization, Berlin: Springer-Verlag, 1991.

Ottinger, R.L.; Wooley, D.R.; Robinsson, N.A.; Hodas D.R.; Babb S.E. Environmental Costs of Electricity. New York: Oceana Publications, Inc., 1991.

Panzutti, N. Utilização e conservação dos fragmentos do cerrado no Estado de São Paulo. IEA, 2003.

Parfomak, P.W. Falling Generation Costs, Environmental Externalities and the Economics of Electricity Conservation. Energy Policy, 25, pp. 845-860, 1997.

PDD - Project Design Document. Bioenergia Cogeradora S.A. 2005.

PDD - Project Design Document. Termoelétrica Santa Adélia (TSACP). 2005.

PDD - Project Design Document. Projeto de Cogeração com Bagaço Cruz Alta (PCBCA). 2005. 
PDD - Project Design Document. Projeto de Cogeração com Bagaço Lucélia (PCBL). 2005.

PDD - Project Design Document. Projeto de Cogeração Santa Terezinha - Tapejara. 2005.

PDD - Project Design Document. Projeto de Cogeração com Bagaço Nova América. 2005.

PDD - Project Design Document. Projeto de Cogeração com Bagaço Jalles Machado (PCBJM). 2005.

PDD - Project Design Document. Projeto de Cogeração com Bagaço Colombo (PCBC). 2005.

PDD - Project Design Document. Projeto de Cogeração com Bagaço Usinas Caeté Sudeste. 2005 .

PDD - Project Design Document. Projeto de Cogeração com Bagaço Coinbra. 2005.

PDD - Project Design Document. Projeto de Cogeração com Bagaço Campo Florido. 2005.

PDD - Project Design Document. Projeto de Cogeração com Bagaço Serra (PCBS). 2005.

PDD - Project Design Document. Projeto de Cogeração com Bagaço Coruripe (PCBC). 2005.

PDD - Project Design Document. Projeto de Cogeração com Bagaço Zillo Lorenzetti (ZLBCP). 2005.

PDD - Project Design Document. Projeto de Cogeração Central Energética Rio Pardo (CERPA). 2005.

PDD - Project Design Document. Projeto de Cogeração com Bagaço Alta Mogiana (PCBAM). 2005.

PDD - Project Design Document. Projeto de Cogeração com Bagaço Cerradinho (PCBC). 2005 .

PDD - Project Design Document. Projeto de Cogeração com Bagaço Equipav. 2005.

PDD - Project Design Document. Projeto de Cogeração com Bagaço Moema (PCBM). 2005.

PDD - Project Design Document. Projeto de Cogeração com Bagaço Alto Alegre (PCBAA). 2005 . 
PDD - Project Design Document. Projeto de Cogeração com Bagaço Vale do Rosário (PCBVR). 2005.

PDD - Project Design Document. Projeto de Cogeração com Bagaço Santa Elisa (PCBSE). 2005.

PDD - Project Design Document. Projeto de Cogeração com Bagaço Santa Cândida (PCBSC). 2005.

PDD - Project Design Document. Vinasse Anaerobic Treatment Project - Compañía Licorera de Nicaragua, S. A. (CLNSA). 2005.

Pearce, D.; Bann, C.; Georgiou, S. The Social Cost of Fuel Cycles. London: HMSO, 1992.

Pearce, D. The social costs of fuel cycles. A report for the UK Department of Trade and Industry. HMSO, London, 1992.

Pearce, D. Costing the Environmental Damage from Energy. London: E and FN Spon, 1995.

Pindyck R.; Rubinfeld D. Microeconomia. Person Prentice Hall, São Paulo, 5a Edição, 2002.

Pricewaterhouse Coopers - Estudo do novo modelo do setor elétrico. Energy and Utilities Group, São Paulo, 2004.

PROINFA - Programa de Incentivo às Fontes Alternativas de Energia Elétrica. http://www.proinfa.com.br, Outubro de 2006.

Putta, S.N. Methods for Valuing and Incorporating Environmental Costs in Electric Resource Planning and Acquisition. EUA, 1991.

Reis, T.; Pereira, O. Emissões de gases de efeito estufa no sistema interligado nacional: metodologia para definição de linha de base. XVII SNPTEE, 2003.

RER - Regional Economic Research, Inc. The Air Quality Valuation Model. San Diego: RER, 1994.

Rosen, M. A.; Dincer, I. Exergy analysis of waste emissions. International Journal of Energy Research. n. 23. p. $1153-1163,1999$. 
Rowe, R.D.; Lang, C.M.; Chestnut, L.G.; Latimer, D.A.; Rae, D.A.; Bernow, S.M.; White, D.M. New York State Environmental Externalities Cost Study. New York: Oceana Publications, Inc., 1995.

Sandler T.; Cornes R. The Theory of Externalities, Public Goods, and Club Goods. Cambridge University Press, 1986.

Scienceman, D.M. The emergence of emonomies. Proceeding. The International Society for Social System Science. 33 rd . Meeting. Edimburg. Vol III, 1989.

Schuman, M.; Cavanagh,R. A Model Conservation and Electric Power Plan for the Pacific Northwest, Appendix 2: Environmental Costs. Seattle: NCAC, 1982.

Secretaria de Energia, Recursos Hídricos e Saneamento do Estado de São Paulo. Balanço Energético do Estado de São Paulo - BESP. São Paulo, 2005.

Service Energy. Cogeração e o Plano Prioritário Termoelétrico. São Paulo, 2002.

Silva, C.L.; Granato, E.F.Geração de energia elétrica a partir do resíduo vinhaça. Artigo 023, AGRENER 2002.

Silva, M.R.S. (1998). Simpósio: Saúde e Meio Ambiente. Ribeirão Preto. Departamento de Clínica Médica da Faculdade de Medicina, da Universidade de São Paulo, USP. 28 de maio, 1998.

SMA - Secretaria de Estado do Meio Ambiente. Cerrado: bases para conservação e uso sustentável das áreas de cerrado do estado de São Paulo. São Paulo, serie PROBIO/SP 113p, 1997.

Souza, Z; Azevedo, P. Estratégias adotadas pelo setor sucroalcooleiro na geração de excedentes de energia elétrica. AGRENER GD 2004 - 5o Encontro de Energia no Meio Rural e Geração Distribuída, 2004.

Sundqvist, T. Power Generation Choice in the presence of environmental externalities. Tese de Doutorado, Lulea University of Technology, 2002.

Szargut, J.; Morris, D.R.; Steward, F.R. Exergy analysis of thermal, chemical, and metallurgical process. New York, Hemisphere Publishing Co, 1988. 
Szargut, J. Exergy analysis of thermal processes; ecological cost. In: Proceedings of the International Workshop “Advances in Energy Studies: energy flows in ecology and economy. Porto Venere, Itália, 1999.

Szmrecsányi, T. Tecnologia e degradação ambiental: O caso da Agroindústria canavieira no Estado de São Paulo. Informações Econômicas, v.24, n.10, p.73-81, 1994.

Unido - UNITED NATIONS INDUSTRIAL DEVELOPMENT ORGANIZATION. Towards a cleaner and mores profitable sugar industry. Austria: Marcia Hill v.1 e 2, 1997.

Velázquez, S.G. A cogeração de energia no segmento de papel e celulose: contribuição à matiz energética do Brasil. Dissertação (Mestrado), PIPGE/USP, São Paulo, 2000.

Victoria, R. F. Controle de plantas daninhas na cultura da cana-de-açúcar. Curso de produção de cana-de-açúcar. Piracicaba, SP. Escola Superior de Agricultura "Luiz de Queiroz", Universidade de São Paulo, 1993.

Walter, A.; Nogueira, L. Produção de Eletricidade a partir da Biomassa. Universidade do Amazonas, AM, Tecnologias de Conversão Energética da Biomassa, $1^{\circ}$ Ed., Capítulo XI, Amazonas, Brasil, 1997.

Wark, K. Jr. Advanced Thermodynamics for Engineers. Mc Graw-Hill, Inc. Series in Mechanical Engineering. New York, USA, 1995.

Wenzel, H.; Haushild, M.; Alting, L. Environmental Assessment of Products. Bonton/Dordrecht/London: Kluwer Academic Publisehrs. v.1 e 2, 1997.

Wylen, G.; Borgnakke, C.; Sonntag, R. Fundamentos da Termodinâmica, Ed. Edgard Blücher, tradução da 5o ed. americana, 1998. 


\section{ANEXO A - COGERAÇÃO - TECNOLOGIAS E ASPECTOS TÉCNICOS NA GERAÇÃO DE ELETRICIDADE A PARTIR DA BIOMASSA}

\section{A.1. ASPECTOS CONCEITUAIS}

O objetivo deste anexo é apresentar os conceitos básicos da cogeração e os aspectos técnicos e tecnológicos relacionados com projetos de geração de energia elétrica. A intenção não é apresentar todas as tipologias e variações dos principais sistemas de potência, mas apresentar os ciclos de potências mais relevantes e os principais componentes que os integra.

Esta temática está diretamente relacionada com a avaliação das externalidades, pois dependendo do sistema de potência, alteram-se os efeitos externos associados, como por exemplo, as emissões atmosféricas.

\section{A.1.1. DEFINIÇÃO}

Segundo a Agência Nacional de Energia Elétrica ${ }^{71}$ na Resolução ANEEL No 021, de 20 de janeiro de 2000 e, posteriormente na Resolução Normativa $N^{\circ} 235$, de 14 de novembro de 2006 são definidos os requisitos necessários à qualificação de Centrais Cogeradoras de Energia. Sendo a cogeração definida da seguinte forma:

Art. $3^{\circ}$. Inciso I - A cogeração: processo operado numa instalação específica para fins da produção combinada das utilidades calor e energia mecânica, esta geralmente convertida total ou parcialmente em energia elétrica, a partir da energia disponibilizada por uma fonte primária.

Esta mesmo Resolução estabelece os requisitos mínimos de racionalidade energética para a Central Cogeradora, relacionando fatores de ponderação à potência instalada e ao principal combustível $^{72}$.

\footnotetext{
${ }^{71}$ na Legislação Básica do Setor Elétrico Brasileiro, Livro II - Resoluções.

72 o combustível foi subdividido em: a) Derivados do Petróleo, Gás Natural e Carvão; e, b) Demais fontes.
} 


\section{A.1.2. A QUESTÃo ENERGÉTICA}

A atividade de cogeração com aproveitamento na geração de eletricidade contribui para o uso racional dos recursos energéticos e um melhor aproveitamento dos combustíveis melhorando a eficiência global da planta cogeradora.

A incorporação de sistemas de cogeração ao Sistema Interligado Nacional traz benefícios devido ao fato de aumentar a oferta de energia elétrica com o uso mais eficiente do combustível. Colaborando, desta forma, na implementação de um modelo sustentável de desenvolvimento. O sistema elétrico de distribuição local também é beneficiado seja com a melhora dos indicadores de prestação de serviço ou com o aumento na qualidade da energia elétrica disponibilizada.

No entanto, alguns problemas em relação à integração do sistema cogerador ao sistema interligado estão presentes sob os aspectos da interconexão, bem como manobras e religamentos nas linhas da concessionária (Clementino, 2004). Também notas-se a presença modesta na matriz energética brasileira em função da alta disponibilidade e do baixo custo da energia elétrica de base hidroelétrica fornecida pelas concessionárias somada à ausência de políticas que efetivamente alavanquem essa atividade.

\section{A.1.2. CATEGORIAS DE COGERAÇÃo}

Basicamente, podem-se dividir os sistemas de cogeração em duas categorias que estão diretamente relacionadas com a seqüência de utilização da energia (figura A.1.), seja ela proveniente de um combustível utilizado em uma máquina térmica ou de um processo industrial em que a energia térmica é um rejeito, permitindo a seguinte classificação:

- Topping cycle, onde a produção de potência ${ }^{73}$ ocorre antes da etapa do processo produtivo que utiliza energia térmica. E dependendo da necessidade do processo, o vapor de processo, normalmente a baixa pressão e temperatura, pode ser extraído da turbina num estágio intermediário ou retirado da exaustão da turbina ${ }^{74}$. Isto é, o calor

\footnotetext{
${ }^{73}$ mecânica e/ou elétrica.

${ }^{74}$ neste caso a turbina é chamada de turbina de contrapressão.
} 
rejeitado é utilizado como calor útil para o processo. Esta categoria de sistemas de cogeração é comum no setor sucroalcooleiro e na indústria química; ou,

- Bottoming cycle, nesta categoria de ciclo o calor primário é usado a alta temperatura diretamente no processo e o calor residual é recuperado e utilizado para gerar eletricidade, dando forma a um ciclo com rendimento inferior ao acima descrito. Esta categoria é comum em indústrias siderúrgicas e cimenteiras.

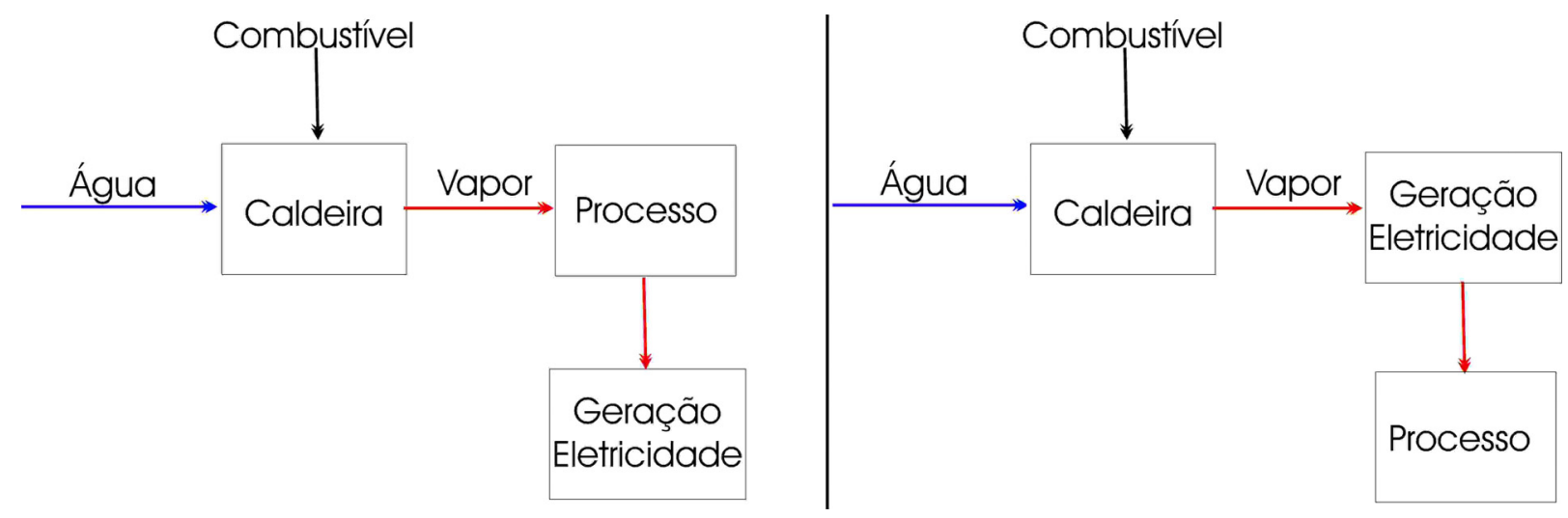

Figura A.1. Ilustração do Bottoming Cycle e Topping Cycle respectivamente.

\section{A.1.3. PRINCIPAIS CICLOS TÉRMICOS}

A princípio, sistemas de cogeração podem empregar qualquer ciclo térmico. Em todos eles a rejeição de calor não convertido em potência mecânica pode ser usada para atender uma determinada demanda térmica, desde que, as temperaturas disponíveis sejam compatíveis com a requerida. Assim, os ciclos com turbinas a vapor e a gás são os que tendem a melhor se ajustar aos requerimentos típicos de energia elétrica e térmica, e, portanto, são os mais usados nos processo de cogeração (Brighenti, 2003).

O rendimento térmico do ciclo com cogeração é calculado somando o total de energia utilizada, ou seja, a energia elétrica gerada mais a energia térmica utilizada no processo, dividindo-se pelo total da energia fornecida pelo combustível. A depender do processo, o rendimento térmico da cogeração pode chegar a 80,0 \% (Service, 2002). 
Dentre os ciclos térmicos ${ }^{75}$ para geração de energia elétrica os mais utilizados são o Ciclo Rankine, Brayton e o Ciclo Combinado.

\section{A.1.3.1. CICLO RANKINE}

No ciclo Rankine é utilizado o calor proveniente da queima de combustíveis para a geração de vapor numa caldeira ${ }^{76}$. A energia térmica gerada pode ser utilizada para calor de processo e para geração de eletricidade em um gerador elétrico acionado por uma turbina a vapor. $\mathrm{O}$ rendimento térmico máximo deste processo é de aproximadamente 30,0 \% (Service, 2002).

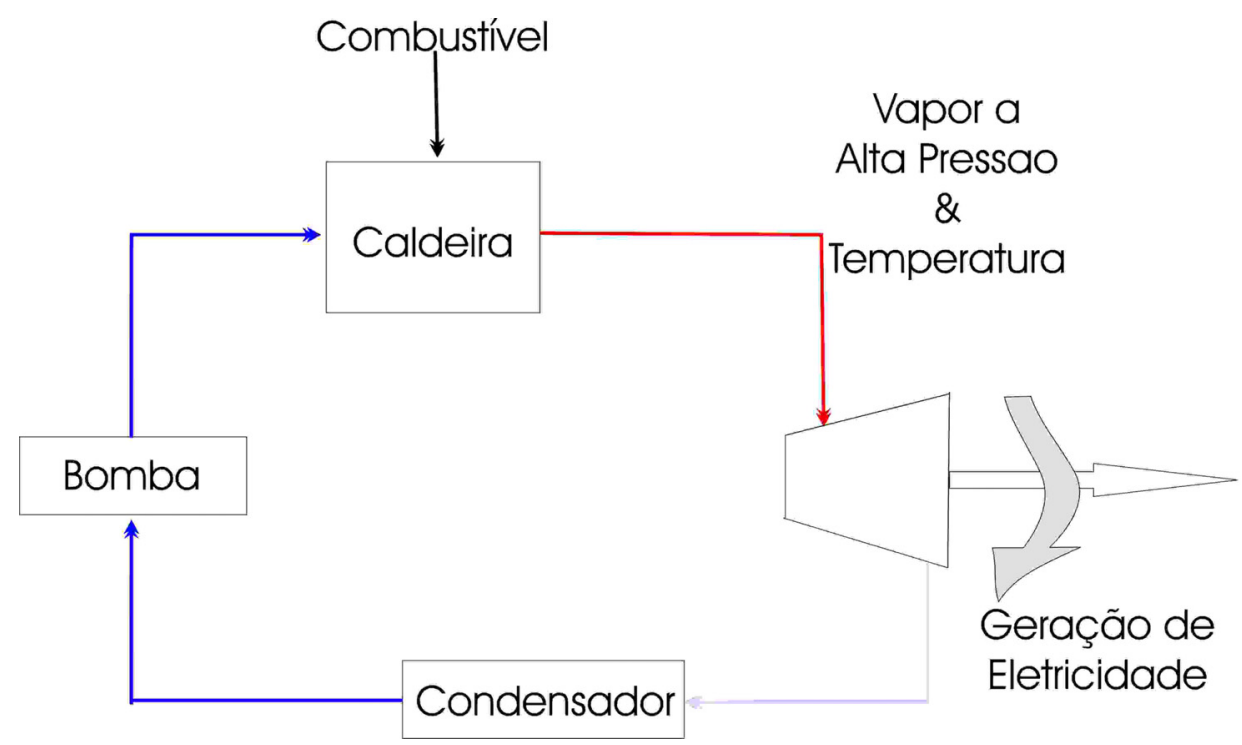

Figura A.2. Ilustração do ciclo Rankine.

A cogeração, entretanto, utiliza o calor residual do vapor, geralmente de baixa pressão, da exaustão da turbina (turbina de contrapressão), ou de uma extração numa turbina de condensação. Este é o processo mais comum utilizado em cogeração.

Na literatura (Wylen, 1998), algumas variações do ciclo Rankine são encontradas, tais como: o ciclo com reaquecimento visando um aumento no rendimento do ciclo Rankine via incremento da pressão no processo de fornecimento de calor, evitando assim o excesso de umidade nos estágios de baixa pressão da turbina; o ciclo regenerativo que basicamente envolve a utilização de aquecedores da água de alimentação.

\footnotetext{
${ }^{75}$ os ciclos Otto e Diesel utilizados nos grupos geradores de pequeno porte serão desconsiderados nesta discussão por não serem aplicáveis à indústria sucroalcooleira.

${ }^{76}$ ou gerador de vapor.
} 


\section{A.1.3.2. CICLO BRAYTON}

No ciclo Brayton, com turbina a gás, o ar atmosférico é continuamente succionado pelo compressor, onde é comprimido para alta pressão. O ar comprimido entra na câmara de combustão $^{77}$ e é misturado ao combustível quando ocorre a combustão resultando em gases com alta temperatura. Os gases provenientes da combustão se expandem através da turbina e são descarregados na atmosfera. Parte do trabalho desenvolvido pela turbina é usado para acionar o compressor e o restante é utilizado para acionar um gerador elétrico ou um dispositivo mecânico.

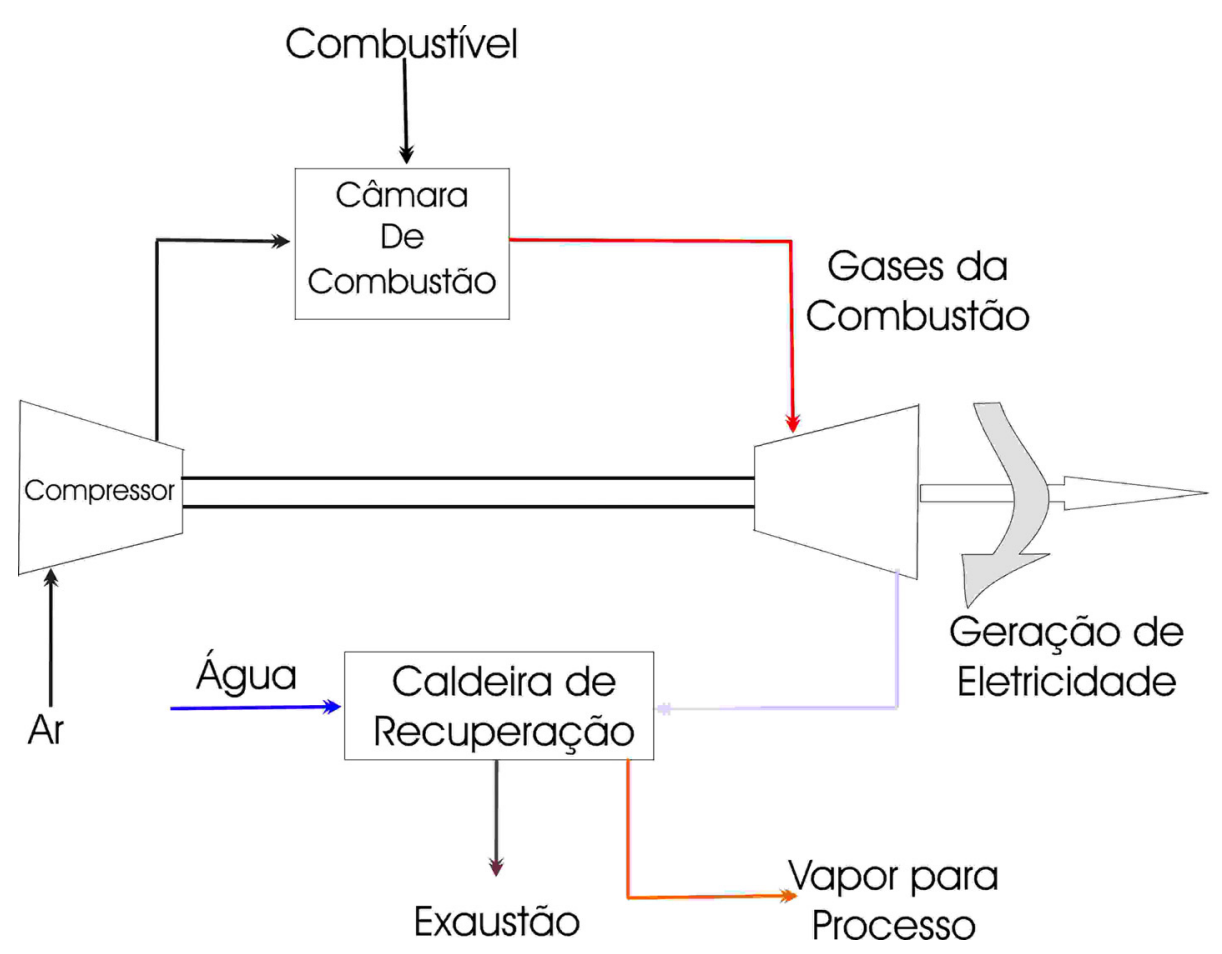

Figura A.3. Ilustração do ciclo Brayton com cogeração.

O rendimento térmico do ciclo Brayton é de aproximadamente 35,0\%, mas, atualmente existem turbinas que atingem um rendimento de 41,9 \% (Service, 2002). A cogeração neste ciclo é obtida através da adição de uma caldeira de recuperação de calor. Neste caso, os gases de exaustão da turbina são direcionas para a caldeira de modo a gerar vapor que é utilizado no processo industrial.

\footnotetext{
77 também conhecido como combustor
} 


\section{A.1.3.3. CICLO COMBINADO}

Um ciclo combinado é, numa única planta, constituído por dois ou mais ciclos termodinâmicos cascateados. Em especial dois ciclos de potência têm apresentado aceitação para esta topologia: o ciclo Brayton e o Rankine. Neste tipo de arranjo, o rejeito térmico de um sistema é usado parcial ou totalmente como insumo energético para o outro sistema. No caso de geração de eletricidade, através do ciclo combinado gas-vapor ${ }^{78}$, os gases de exaustão da turbina a gás estão numa temperatura relativamente alta, normalmente entre $450{ }^{\circ} \mathrm{C}$ a 550 ${ }^{\circ} \mathrm{C}$.

Deste modo, o fluxo de gás quente pode ser utilizado numa caldeira de recuperação de calor para geração de vapor, que serve como fluido de trabalho para o acionamento de uma turbina a vapor, gerando um adicional de energia. Portanto, o ciclo combinado tem uma eficiência térmica maior que a dos ciclos Rankine e Brayton separadamente. Este tipo de processo de cogeração é a melhor opção para as aplicações nas quais a demanda de eletricidade é superior à demanda de vapor como, por exemplo, nas indústrias eletrointensivas (Service, 2002).

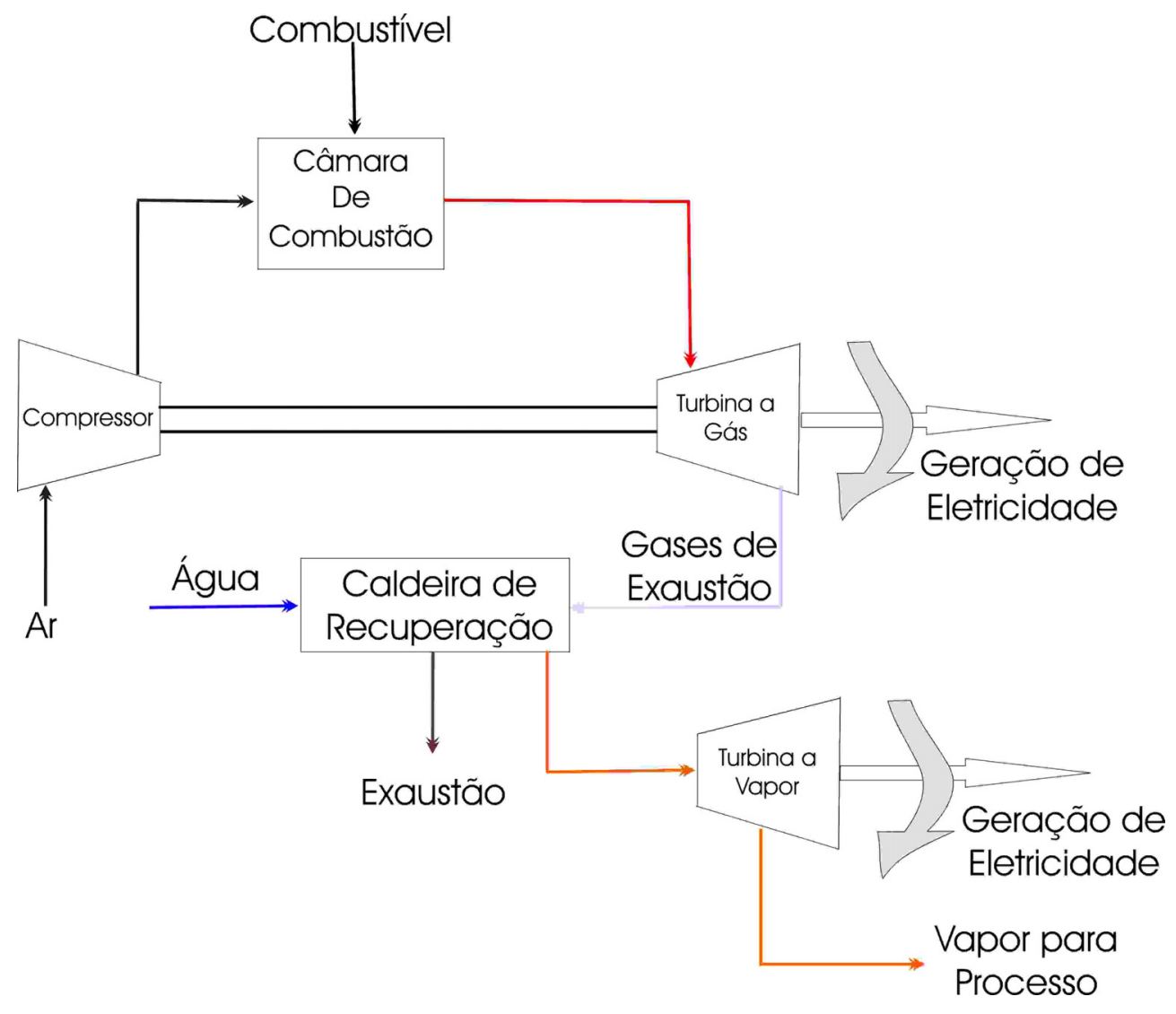

Figura A.4. Ilustração do ciclo combinado com cogeração.

\footnotetext{
${ }^{78}$ Brayton- Rankine.
} 
O acréscimo de potência alcançado em um ciclo combinado é, em geral, da ordem de $50 \%$ da potência da turbina a gás e a eficiência global passa da média de $30 \%$ do ciclo simples e atinge valores máximos em torno dos 55 a $60 \%$ em ciclos combinados comerciais.

Com a evolução do conceito de sistema combinado de potência, diversas configurações foram desenvolvidas e, a título de ilustração algumas combinações são citadas ${ }^{79}$ :

- Sistema combinado de potência com turbina a gás e a vapor;

- Sistema combinado de potência com turbina a gás e ciclo Rankine multi-pressão;

- Sistema combinado com gaseificador integrado e sistema com turbina a gás e a vapor; e,

- Sistemas avançados com turbinas a gás:

- Sistema combinado com turbina a gás com resfriamento intermediário e final do ar de combustão;

○ Sistema combinado com recuperação termoquímica; e,

- Sistema combinado com ciclo de Kalina.

$\mathrm{O}$ autor $^{80}$ também apresenta a evolução contínua nos valores de temperatura de entrada e trabalho específico nas turbinas bem como no rendimento global em sistemas combinados.

\section{A.2. A COGERAÇÃO COM O EMPREGO DA BIOMASSA}

Convém salientar que o principal ciclo de potência utilizado pela indústria sucroalcooleira é o ciclo Rankine com a observação que há extração de parte do vapor da(s) turbina(s) para alimentar os processos industriais, caracterizando-se como um sistema topping cycle. Segundo Velázquez (2000), esta é a configuração mais comum dos processos industriais que envolvem cogeração devido ao requisito de vapor de baixa pressão.

\footnotetext{
${ }^{79}$ maiores detalhes podem ser encontrados nas notas de aula do Prof. Dr. Silvio de Oliveira Júnior, Sistemas Combinados de Potência - Geração Termoelétrica, 2001.

${ }^{80}$ Prof. Dr. Silvio de Oliveira Júnior
} 
As recentes expansões das usinas deste setor para geração de excedentes de eletricidade passíveis de exportação ao SIN estão associadas à evolução dos ciclos à vapor, como: o aumento da pressão nas caldeiras e condensadores o que implica num aumento na temperatura do vapor; melhora na eficiência dos equipamentos envolvidos (turbinas, caldeiras, geradores, etc...); o que resultam num aumento do trabalho líquido e da eficiência do ciclo.

No entanto, outras formas de emprego da biomassa são possíveis além da queima direta da biomassa da cana nas caldeiras de vapor. Este assunto será tratado a seguir.

\section{A.2.1. CICLO INTEGRAdo DE TURBINAS A GÁS COM GASEIFICAÇÃo DE BIOMASSA}

A tecnologia de gaseificação é a conversão de qualquer combustível líquido ou sólido, como a biomassa, em um gás energético através da oxidação parcial à temperatura elevada. Esta conversão produz um gás combustível que pode ser utilizado em turbinas a gás.

Esta tecnologia tem como benefícios a inexistência de grandes volumes de equipamentos, motor a gás compacto e leve, não necessita de meios refrigerantes e é capaz de atingir plena carga em pouco tempo.

No entanto, apesar da viabilidade técnica, a tecnologia de gaseificação da biomassa precisa superar alguns obstáculos para se tornar uma forma de geração de energia competitiva comercialmente. As dificuldades não residem no processo de gaseificação, mas sim no projeto de um equipamento que deve produzir um gás limpo de alta qualidade e com confiabilidade.

Para Leme et al (2004) o uso de tecnologias de gaseificação de biomassa encontra-se distante ainda da realidade pelos motivos acima apresentados e pela incipiente escala comercial.

O ciclo integrado de turbinas a gás com gaseificação de biomassa está relacionado com mercados específicos, ou nichos de mercado, tais como projetos com subprodutos economicamente atrativos, regiões com restrições a combustíveis fósseis ou com custos elevados e áreas com: prioridade de desenvolvimento rural, disponibilidade de rejeitos ou resíduos diversos e onde os custos da biomassa são significativamente baixos.

A seguir, algumas tecnologias são brevemente apresentadas: 
- Biomass Integrated Gaseification Gas Turbine (BIG-GT);

- Biomass Integrated Gaseification Steam Injected Gas Turbine (BIG-STIG);

- Biomass Integrated Gaseification Intercooled Steam Injected Gas Turbine (BIGISTIG); e,

- Biomass Integrated Gaseification Gas Turbine Combines Cycle (BIG-GTCC).

Cada um desses itens é apresentado nos próximos tópicos, não sendo objeto desse estudo uma análise econômica ou avaliação técnica aprofundada.

\section{A.2.1.1. BIOMASS INTEGRATED GASEIFICATION GAS TURBINE (BIG-GT)}

A geração de eletricidade com a biomassa nessa tecnologia que integra a gaseificação do combustível e turbinas a gás em ciclo simples é conhecida como BIG-GT. Neste ciclo a biomassa é gaseificada e o gás combustível é utilizado para o acionamento de uma turbina a gás acoplada a um gerador elétrico, produzindo a energia elétrica. Como indicado por (Carpentieri, 1993), este é o ciclo com gaseificação mais simples, de menor eficiência e menor custo de investimento.

Devido à sua relativamente baixa eficiência em geração de energia elétrica, o ciclo simples de turbina a gás não se aplica satisfatoriamente em indústrias com uma larga variação de demanda térmica.

\section{A.2.1.2. BIOMASS INTEGRATED GASEIFICATION STEAM INJECTED GAS TURBINE (BIG-STIG)}

A combinação de gaseificadores de biomassa com turbinas a gás do tipo aeroderivativas, nas quais se utiliza a injeção de vapor no fluxo do fluído de trabalho e também o resfriamento intermediário do ar na compressão. O equipamento BIG-STIG opera com a gaseificação da biomassa fornecendo combustível na turbina a gás que aciona um gerador de energia elétrica.

A injeção do vapor na turbina a gás tem como objetivo aumentar a potência gerada na máquina e para reduzir as emissões de $\mathrm{NO}_{\mathrm{x}}$. O conceito associado a esta modificação para o 
incremento da potência é o aumento do fluxo mássico e do calor específico do fluido de trabalho que entra na turbina e, conseqüentemente, da energia dos gases. Isto é, o aumento na potência e no rendimento térmico da turbina mesmo com o aumento do consumo de combustível necessários para aquecer o vapor até a temperatura adequada é compensado no momento da expansão do vapor através da turbina. $\mathrm{O}$ vapor é injetado na própria câmara de combustão. Sendo possível, ainda, recuperar calor dos gases de exaustão da turbina.

A elevação da eficiência global atinge a casa dos $52 \%$ e a potência total chega a ser $30 \%$ maior, com o benefício de redução de equipamento como o conjunto turbogerador a vapor, o condensador e subsistemas de resfriamento de um ciclo combinado. Por outro lado, há a necessidade de sistemas complexos de tratamento de água, sem os quais a degradação da turbina inviabiliza a aplicação.

\section{A.2.1.3. BIOMASS INTEGRATED GASEIFICATION INTERCOOLED STEAM INJECTED GAS TURBINE (BIG-ISTIG)}

A diferença fundamental entre a tecnologia BIG-ISTIG é a introdução de um resfriador para reduzir a temperatura do ar que está sendo comprimido para alimentar a combustão, reduzindo a potência requerida para a sua compressão, elevando a potência disponível da turbina graças a maior taxa de elevação da temperatura de entrada dos gases no combustor, o que contribui significativamente para elevar a eficiência termodinâmica do ciclo.

A redução da potência necessária para a compressão do ar tem como conseqüência a melhora do rendimento térmico do ciclo e a elevação da potência útil disponibilizada na máquina. Com menor temperatura, o volume específico do ar é menor e o trabalho necessário para acionar o compressor é reduzido significantemente, consumindo uma menor potência.

A aplicação de intercoolers, resfriadores intermediários de compressão, reduz a temperatura do ar ao fim da compressão permitindo a injeção de mais combustível e a conseqüente geração de mais potência.

Tanto o BIG-STIG e o BIG-ISTIG esbarram em dois pontos fundamentais que podem inviabilizar a sua aplicação: 
- a qualidade do vapor d'água para adequada operação e vida útil destas turbinas é rígida. Esta necessidade imperiosa está associada a sistemas de tratamento sofisticados para a produção de água desmineralizada, de elevado custo, que será inteiramente devolvida à atmosfera junto aos gases de exaustão, elevando o custo operacional; e,

- como a água não é reaproveitada, torna-se condição imperativa a disponibilidade de recursos hídricos abundantes na área de instalação (Neto, 2001).

\section{A.2.1.4. BIOMASS INTEGRATED GASEIFICATION GAS TURBINE COMBINED CYCLE (BIG-GTCC)}

O ciclo de geração termoelétrica que utiliza uma combinação de turbinas a gás e a vapor, conhecido como ciclo combinado, integrado a um gaseificador de biomassa para produção do gás combustível resulta no sistema BIG-GTCC.

Os gases de exaustão das turbinas a gás são ricos em oxigênio devido à necessidade de ar para refrigeração, fazendo com que a quantidade de ar admitida atinja valores da ordem de $300 \%$ de excesso de ar de combustão, carregando consigo o calor rejeitado. Por esse motivo pode ser utilizado como comburente em uma caldeira de recuperação para efetuar uma queima suplementar, gerando uma quantidade de vapor até 2,5 vezes maior que a gerada em uma caldeira puramente de recuperação de calor dos gases (Clementino, 2004).

\section{A.3. ALTERNATIVAS TECNOLÓGICAS PARA COGERAÇÃo}

Como foi visto na subseção anterior, nas plantas de cogeração vários arranjos de equipamentos podem ser empregados. Desde turbinas de simples estágio acopladas a caldeiras convencionais até sistemas mais complexos como, por exemplo, a utilização de gaseificadores em conjunto com turbinas a gás.

As plantas de cogeração recebem denominações de acordo com os dispositivos, arranjos, equipamentos e combustível utilizados. 


\section{A.3.1. TURBINA A VAPOR EM CONTRAPRESSÃO}

Este tipo de equipamento é encontrado em arranjos convencionais de cogeração ${ }^{81}$ (utilizando o ciclo Rankine). A turbina é alimentada por uma caldeira equipada com superaquecedor, em que a turbina descarrega seu escape para processos à jusante.

Devido às características técnicas desse sistema, a geração de trabalho é relativamente pequena, rejeitando quantidades maiores de calor quando comparadas com outras tecnologias de cogeração.

Portanto, nas turbinas de contrapressão o vapor é expandido até um nível onde ainda está substancialmente acima da pressão ambiente. Este vapor que deixa a turbina é direcionado para satisfazer as necessidades dos processos onde, geralmente, há a condensação para água novamente.

\section{A.3.2. TURBINA DE CONDENSAÇÃO E EXTRAÇÃO}

No sistema de Turbina de condensação e extração ${ }^{82}$ existem pontos de derivação de pressões intermediárias na turbina, os quais extraem vapor em um ou mais pontos do canal de extração para atender ao processo, enquanto o restante do vapor é levado a pressões sub-atmosféricas, aumentando a geração de eletricidade por unidade de vapor comparado com a turbina de contrapressão.

Com o desenvolvimento de novas tecnologias, existe uma tendência de se efetuar investimentos em caldeiras de alta pressão e em turbinas de condensação (Clementino, 2004).

\footnotetext{
${ }^{81}$ incluindo o setor sucroalcooleiro.

${ }^{82}$ Condensing Extraction Steam Turbine (CEST)
} 


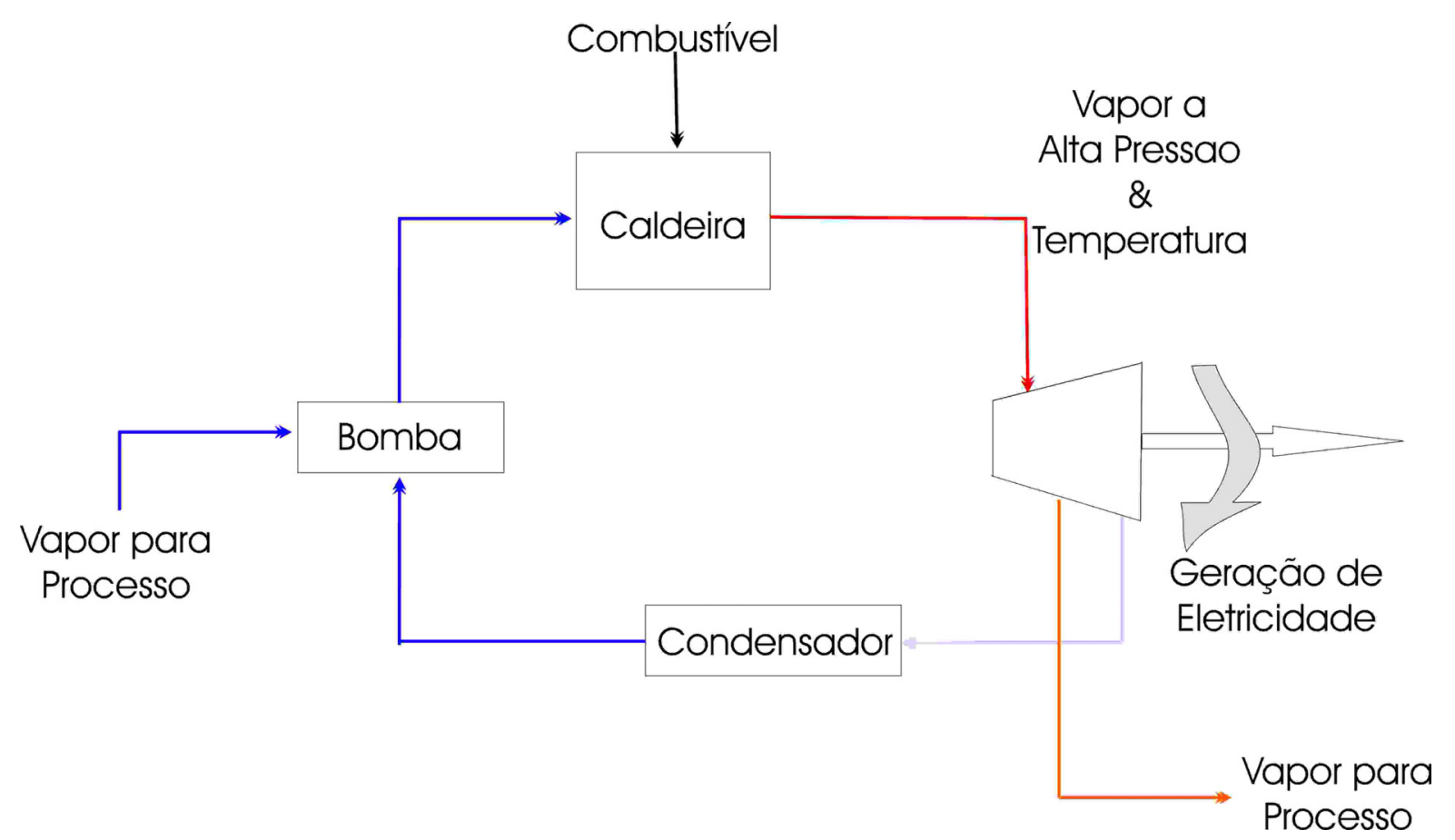

Figura A.5. Turbina de condensação e extração num sistema de cogeração.

\section{A.3.3. TURBINA A GÁS SIMPLES}

A tecnologia de geração de energia elétrica que tem despertado grande interesse é a de turbina a gás. As características mais importantes nesse equipamento são:

- Capacidade de expansão modular;

- Simplicidade na implantação dos módulos;

- Menor tempo de comissionamento;

- Investimento reduzido quando comparado com o conjunto caldeira - turbina a vapor (Clementino, 2004); e,

- Fator de disponibilidade alto.

Outra característica da turbina a gás é a grande quantidade de trabalho necessário no compressor, aproximadamente $40 \%$ da potência desenvolvida na turbina, em contraste com o ciclo Rankine em que apenas $1 \%$ ou $2 \%$ do trabalho da turbina são necessários para acionar a bomba que retorna o condensado para a caldeira (Clementino, 2004). 
Um dos fatores que tornam as turbinas a gás adequadas à cogeração é que os gases de escape, além de apresentarem grandes volumes e temperaturas elevadas, possuem apreciáveis teores de oxigênio. Ao contrário de aparente perda de rendimento térmico, este fato pode propiciar:

- a geração de vapor, por meio de acoplamento de uma caldeira de recuperação ao escape da turbina;

- a utilização direta dos gases em processos de secagem, pré-aquecimento etc; e,

- fonte de calor de sistemas de refrigeração e condicionamento ambiental.

\section{A.3.4. TURBINA A GÁS EM CICLO COMBINADO}

Neste sistema, o vapor da caldeira de recuperação expande-se em turbinas a vapor de contrapressão, de condensação ou mistas, gerando energia elétrica adicional, que é o caso do ciclo combinado.

\section{A.3.5. TURBINA A GÁS COM INJEÇÃO DE VAPOR}

No inicio da década de 1980, surgiu a opção do ciclo de turbina a gás com injeção de vapor Steam Injected Gas Turbine (STIG).

Com a entrada no mercado das turbinas aeroderivativas ${ }^{83}$ foi introduzido o sistema de reinjeção do vapor na própria turbina a gás, ou seja, vapor advindo da caldeira de recuperação transfere calor para as fases a alta pressão que deixam o compressor. Este fato proporciona uma geração complementar de eletricidade no próprio gerador principal, além de reduzir a emissão de óxidos de nitrogênio.

As unidades aeroderivativas permitem, inclusive, aumentar a disponibilidade operativa da instalação devido às características do projeto do equipamento, como alta confiabilidade, tempo reduzido de manutenção e elevado rendimento.

\footnotetext{
${ }^{83}$ turbina baseada na tecnologia adotada para propulsão de aeronaves sendo compactas e de peso reduzido.
} 


\section{A.4. CARACTERÍSTICAS DE GERADORES E EQUIPAMENTOS DE INTERFACE}

Até o momento viu-se que na cogeração, no que se refere à geração de eletricidade, há a transformação da energia mecânica em potência de eixo para energia elétrica através do gerador. No entanto, o processo que origina essa conversão de energia pode apresentar um comportamento constante ou variável.

Para ambos os casos, os geradores de energia elétrica possuem a seguinte classificação:

- síncrono;

- indução; ou,

- corrente contínua $^{84}$.

\section{A.4.1. GERADOR A INDUÇÃO}

Um gerador a indução ${ }^{85}$ tem características semelhantes ao motor de indução, isto é, facilidade no ajuste a torques variáveis e mudanças nas condições de carga. Bem como representam, para o sistema elétrico interligado, uma carga reativa defasada em ambas as configurações.

Este tipo de gerador depende dos responsáveis pela operação da instalação para controlar a velocidade e a freqüência, além da corrente de excitação, a menos que existam capacitores conectados para prover a corrente de excitação.

Algumas vantagens em relação ao gerador síncrono são: a simplicidade no controle e partida e, em algumas situações, a habilidade de restabelecer a operação normalmente após transientes elétricos e mecânicos. Além disso, pode cessar a geração de eletricidade quando a fonte é desligada ${ }^{86}$, reduzindo, dessa forma, a possibilidade de tensões prejudiciais ao sistema serem produzidas por um gerador isolado.

\footnotetext{
${ }^{84}$ onde há a possibilidade de se utilizar conversores estáticos na obtenção de grandezas de freqüência variável. Por exemplo, tensão em $60 \mathrm{~Hz}$.

85 também conhecido na literatura como gerador assíncrono.

${ }^{86}$ se houver capacitores provendo a corrente de excitação.
} 


\section{A.4.2. GERADOR SÍNCRONO}

Geradores síncronos ${ }^{87}$ devem operar precisamente em sincronia com a freqüência do sistema elétrico interligado ${ }^{88}$. Tal fato exige um arranjo especial de controle e proteção para que possa ocorrer o sincronismo com a rede elétrica.

Além dos requisitos especiais de operação, este tipo de gerador pode operar com fator de potência (FP) unitário ou até mesmo ser utilizado para controlá-lo numa instalação industrial, visto que ele pode também operar com o FP adiantado. Existe a possibilidade da operação com velocidades e freqüências variáveis.

\section{A.4.3. GERADOR DE CORRENTE CONTÍNUA}

Esta categoria de gerador pode ser utilizada para carregar sistemas de bateria ou aquecimento de água e outros tipos de carga. Para aplicações em corrente alternada que é o interesse desse trabalho, este gerador pode ser utilizado em conjunto com conversores estáticos para alimentar cargas com esse requisito ou para injetar potência ativa para a rede elétrica.

\section{A.4.4. CONVERSORES ESTÁTICOS}

Um conversor estático tem como objetivo converter correntes alternadas (CA) em correntes contínuas (CC) , CC para CA ou CA para CA em outra freqüência. Normalmente, são também conhecidos como retificadores quando a conversão é de CA para CC ou inversores quando se trata de uma conversão CC para CA.

No entanto, este tipo de equipamento apresenta perdas, redução na qualidade da forma de onda, requisitos de potência reativa além de elevar os custos de implantação o que pode afetar o desempenho do sistema como um todo ao se tratar da qualidade da energia fornecida e os custos envolvidos.

Basicamente, dois tipos de conversores são empregados em sistemas energéticos:

\footnotetext{
${ }^{87}$ este tipo de gerador é largamente empregado nos empreendimentos de geração de eletricidade.

${ }^{88}$ no Brasil essa freqüência é $60 \mathrm{~Hz}$.
} 
- comutados em linha, onde há uma dependência de uma fonte CA para sua operação e consomem potência reativa; e

- autocomutados têm um custo maior que o conversor comutado em linha, mas são capazes de produzir uma melhor forma de onda na saída ${ }^{89}$, não requer uma fonte CA externa para sua operação.

\section{A.4.5. PROTEÇÃO DO SISTEMA DE GERAÇÃO DE ELETRICIDADE}

Quando a instalação onde há cogeração está interligada ao sistema elétrico, o intercâmbio de potência que ocorre na rede introduz variáveis na proteção da linha de distribuição em pelo menos dois aspectos: primeiro, a coordenação entre os equipamentos de proteção e os de seccionamento, pois existe uma parcela de contribuição dos geradores na corrente de falta; em segundo, os geradores também precisam de dispositivos de proteção para condições anormais de operação do sistema elétrico. Além da necessidade de esquemas de proteção contra descargas atmosféricas.

\footnotetext{
${ }^{89}$ distorções na forma de onda podem provocar aquecimento indevido em motores e geradores, equipamentos de medição e interferência entre os equipamentos eletrônicos
} 


\section{ANEXO B - METODOLOGIA DE CÁLCULO DO FATOR DE EMISSÃO DE USINAS GERADORAS DE ELETRICIDADE CONECTADAS AO SISTEMA INTERLIGADO}

\section{B.1. METODOLOGIA BASE}

O objetivo deste anexo é apresentar a metodologia, os aspectos técnicos e relacionados com a quantificação das emissões visando determinar um fator de emissão das usinas geradoras de eletricidade que utilizem fontes renováveis de energia e estejam conectadas ao Sistema Interligado, no caso brasileiro, ao SIN.

A metodologia tomada como referência é a "Consolidated baseline methodology for gridconnected electricity generation from renewable sources" (ACM0002) - Revisão 06 de 19 de maior de 2006.

\section{B.2. ETAPA 01 - CÁLCULO DO FATOR DE EMISSÃO NA OPERAÇÃO (OM)}

Este cálculo deve ser realizado utilizando uma das quatro formas possíveis:

i. OM Simples - deve ser somente utilizado quando até $50 \%$ do total da geração no sistema interligado é composto por fontes de baixo custo e com necessidade prioritária de operação tendo como base:

- A média dos últimos cinco anos; e,

- A produção normal de longo prazo de hidroeletricidade;

ii. OM Simples Ajustado - Essa metodologia separa as plantas de geração em dois grupos: o primeiro contendo as de baixo custo e necessidade prioritária de operação e o segundo com as demais fontes não consideradas; 
iii. OM com Análises de Dados de Despacho - Essa metodologia é a mais recomendada sendo a primeira opção metodológica a ser aplicada. Nos casos onde essa opção não se enquadre o proponente do projeto deve justificar por qual motivo não pode utilizá-la. Nessa impossibilidade as metodologias devem ser empregadas na seguinte ordem: OM simples, simples ajustado e o médio; ou,

iv. OM Médio - Aplicado somente quando mais de $50 \%$ do total da geração no sistema interligado é composta por fontes de baixo custo e com necessidade prioritária de operação, além de não ser possível aplicar (ii) e, quando dados específicos para utilizar (iii) também se encontrarem indisponíveis.

\section{B.2.1. OM SIMPLES}

Este fator de emissão é calculado como a ponderação das emissões na geração de eletricidade $\mathrm{tCO}_{2} / \mathrm{MWh}$ de todas as fontes de energia que atuam no sistema, exceto as que utilizam fontes de baixo custo com necessidade prioritária de operação. O fator de emissão OM simples é dado por:

$$
E F_{\text {OM-Simples }, y}=\frac{\sum_{i, j} F_{i, j, y} \cdot \mathrm{COEF}_{i, j}}{\sum_{j} G E N_{j, y}} \quad \mathrm{tCO}_{2} / \mathrm{MWh} 1
$$

Onde:

$F_{i, j, y} \quad$ É a quantidade de combustível $i$ (em unidade de massa ou volume) consumida por uma planta de geração $j$ no ano $y$. Esse parâmetro é medido com freqüência anual tendo todos os dados analisados e armazenado anualmente em meio eletrônico sendo mantido no decorrer do período de concessão dos créditos e encerrado após 2 anos. As informações poderão ser obtidas do próprio gerador, da instituição responsável pelo despacho ou de estatísticas atualizadas do local.

j Planta de geração de eletricidade conectada ao sistema interligado excluindo as fontes de baixo-custo com necessidade prioritária na geração. Considera também a 
importação de energia elétrica da rede. Neste caso, a quantidade de energia importada é considerada como uma fonte de geração $j$.

$\mathrm{COEF}_{i, j} \quad$ É o coeficiente de emissão de dióxido de carbono para o combustível $i$ $\mathrm{tCO}_{2}$ /unidade de massa ou volume de combustível considerando o conteúdo de carbono presente no combustível utilizado pela planta de geração $j$ e com um percentual de oxidação do combustível por ano $y$. Esse parâmetro é medido com freqüência anual sendo todos os dados analisados e armazenados anualmente em meio eletrônico, mantidos no decorrer do período de concessão dos créditos e encerrado o mesmo após 2 anos. Valores específicos da planta ou do país são preferíveis em relação ao padrão estimado pelo (IPCC, 1996).

$G E N_{j, y} \quad$ É a potência entregue pela planta de geração $j$ ao sistema interligado no ano $y$. Esse parâmetro é medido com freqüência anual sendo todos os dados analisados e armazenados anualmente em meio eletrônico, mantidos no decorrer do período de concessão dos créditos e encerrado o mesmo após 2 anos. As informações poderão ser obtidas do próprio gerador, da instituição responsável pelo despacho ou de estatísticas atualizadas do local.

O coeficiente de emissão de dióxido de carbono é dado por:

$\mathrm{COEF}_{i, j}=\mathrm{NCV} \mathrm{V}_{i} \cdot \mathrm{EF}_{\mathrm{CO}_{2}, i} \cdot \mathrm{OXID}_{i} \quad \mathrm{tCO}_{2} /$ (Unidade de Volume ou Massa 2

Onde os termos acima representam:

$N C V_{i}$ O poder calorífico líquido (conteúdo energético) por massa ou volume de combustível $i$.

$E F_{\mathrm{CO}_{2}, i} \mathrm{O}$ fator de emissão de $\mathrm{CO}_{2}$ por unidade de energia do combustível $i$.

$O X I D_{i} \mathrm{O}$ fator de oxidação do combustível $i$ baseado em (IPCC, 1996).

Quando disponível a informação, deve-se priorizar os valores locais de $N C V_{i}$ e $E F_{C O_{2}, i}$ ou os valores específicos por país e, no último caso, devem-se utilizar os valores mundiais definidos pelo (IPCC, 1996). 
Os dados para os cálculos do fator de emissão simples OM podem ser calculados utilizando um dos seguintes períodos:

- Média de três anos baseadas nas mais recentes estatísticas disponíveis na época do envio do projeto; ou,

- Dados do ano em que o projeto de geração irá ocorrer sendo atualizados pelos dados do período de monitoração;

\section{B.2.2. OM SIMPLES AJUSTADO}

Este método é uma variação do método anterior, visto que ele separa e pondera as plantas em dois grupos. Sendo que o primeiro inclui as fontes de geração de baixo custo com necessidade prioritária para operação $k$ e outro grupo contendo as demais plantas $j$.

$E F_{\text {OM-Simples-Ajustado, } y}=\left(1-\lambda_{y}\right) \cdot \frac{\sum_{i, j} F_{i, j, y} \cdot C O E F_{i, j}}{\sum_{j} G E N_{j, y}}+\left(\lambda_{y}\right) \cdot \frac{\sum_{i, k} F_{i, k, y} \cdot C O E F_{i, k}}{\sum_{k} G E N_{k, y}}$ $\mathrm{tCO}_{2} / \mathrm{MWh} 3$

Onde lambda $\left(^{\lambda_{y}}\right)$ para um dado ano $y$ é dado por:

$\lambda_{y}=\frac{[\text { Númerode horas/anoł Operaçãona Margem }}{8760 \text { horas/and }}[\%]=4$

Para o cálculo da quantidade de horas por ano do numerador de (4) são necessários quatro passos:

- Montar um gráfico de duração de carga cronologicamente (tipicamente em MW) para cada hora do ano e ordená-los da maior carga para menor no padrão de potência definido. Por fim, para encontrar o gráfico desejado basta montar um gráfico com as demandas ordenadas versus às 8760 horas do ano na ordem decrescente; 
- Agrupar os dados de geração obedecendo às distinções (dos agrupamentos) apresentadas na equação (3) e calcular a quantidade anual de energia gerada MWh das fontes de baixo custo e com prioridade na operação;

- Traçar uma linha horizontal no gráfico de duração de carga de modo que a área da curva seja igual à geração total das fontes de baixo custo e com prioridade na operação;

- Determinar o número de horas que as fontes de baixo custo e com prioridade na operação operam marginalmente do seguinte modo:

a - Determinando a intersecção entre a reta e a curva;

b - A diferença entre a quantidade de horas na intersecção e às 8760 horas do ano representa a quantidade de horas que as fontes de baixo custo com prioridade na operação trabalham na margem. Se a reta e a curva não se encontrarem em um ponto, conclui-se que tais fontes não se encontram na margem e $\left(^{\lambda_{y}}\right)$ é igual a zero;

c - Para o cálculo de $\left({ }^{\lambda_{y}}\right)$ basta utilizar o número encontrado em (ii) no numerador de (4);

Conforme ilustrado nas figuras B.1. e B.2. e apresentados na prática nas figuras B.3. e B.4. juntamente com a tabela B.1. a seguir: 


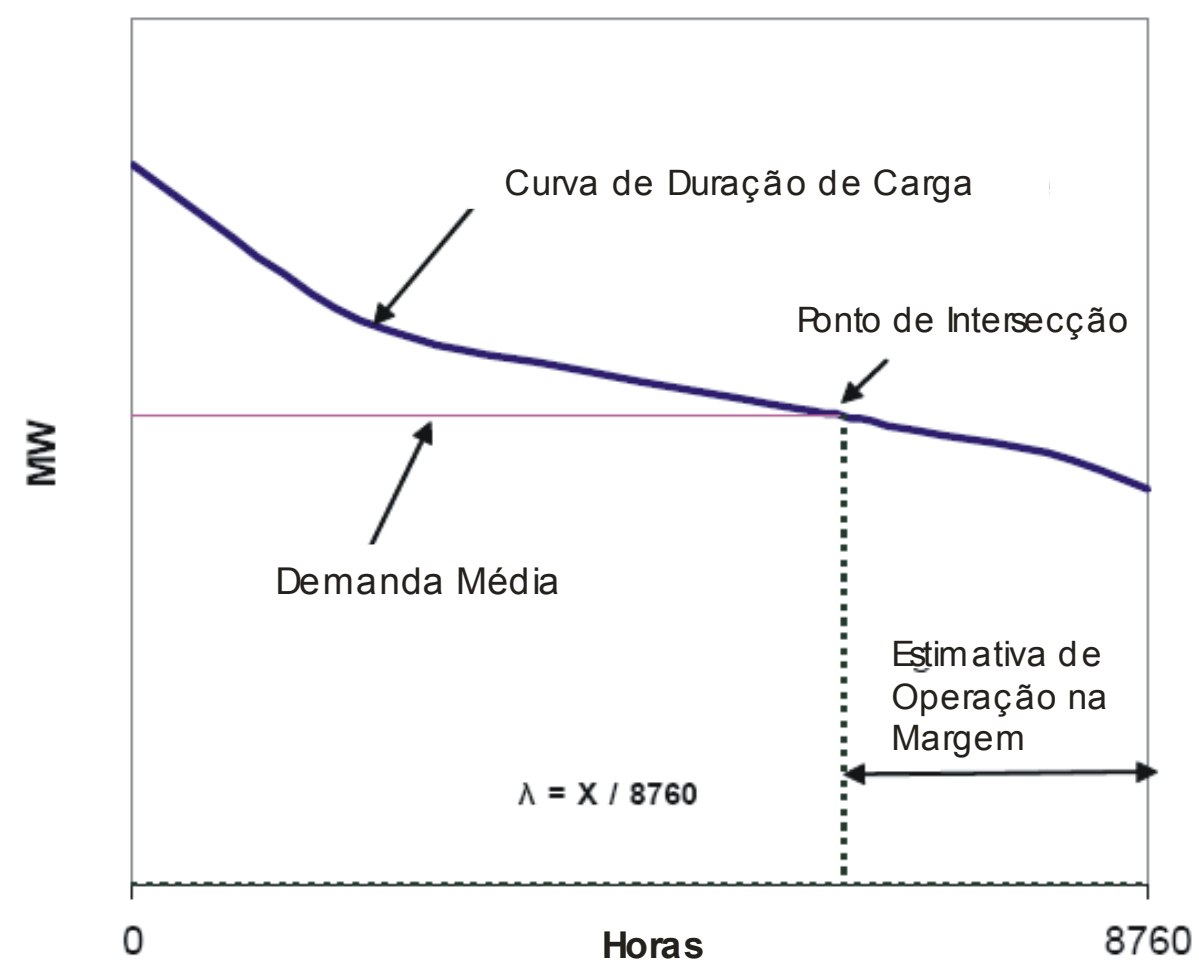

Figura B.1. Ilustração da determinação de lambda para o método OM Simples Ajustado.

Fonte: (EB, 2006) - Adaptado

O parâmetro $\left({ }^{\lambda_{y}}\right)$ é calculado e deve ser armazenado em meio eletrônico anualmente pelo período de concessão dos créditos e após o mesmo, por mais 2 anos.

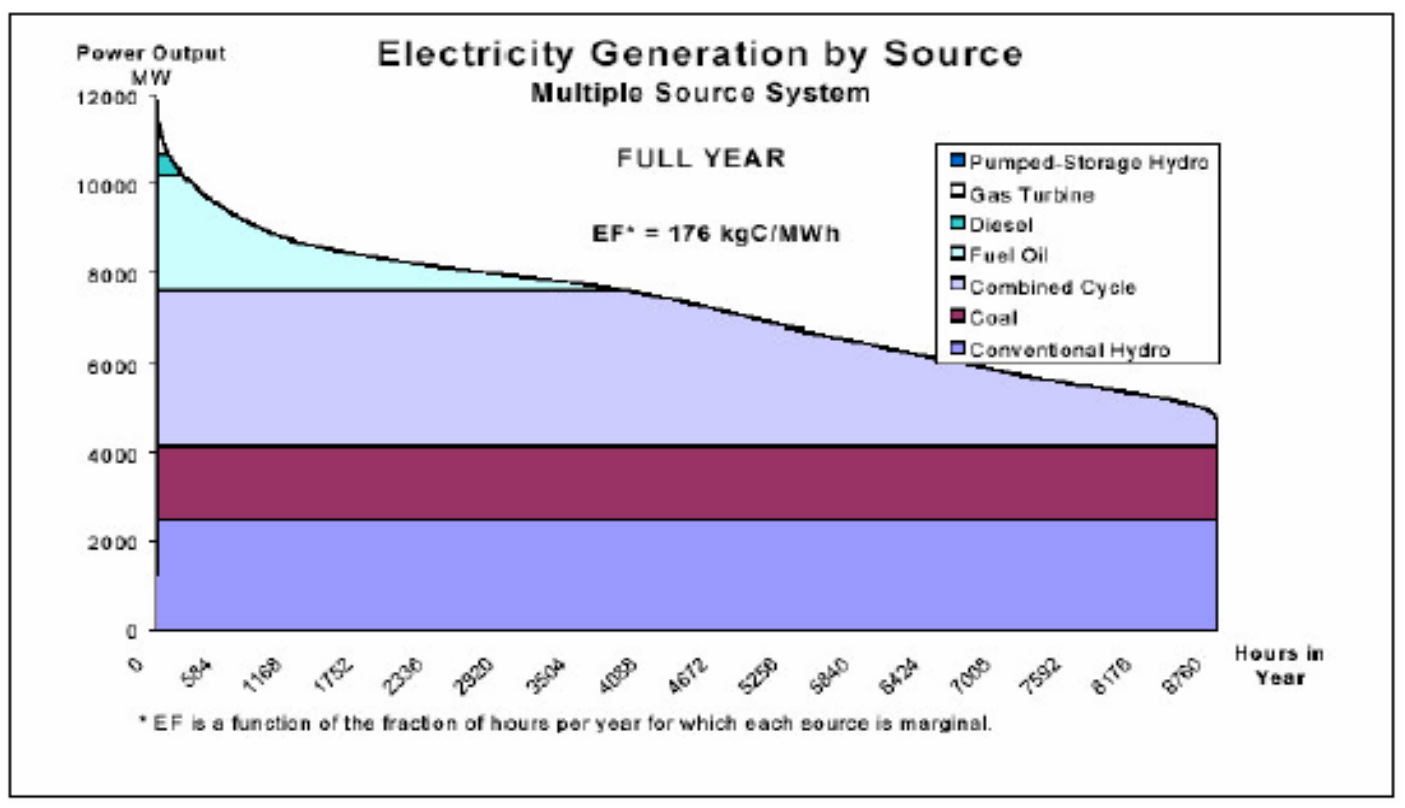

Figura B.2. Ilustração da curva de duração de carga incluindo participação por fonte geradora.

Fonte: (PDD, 2003) 


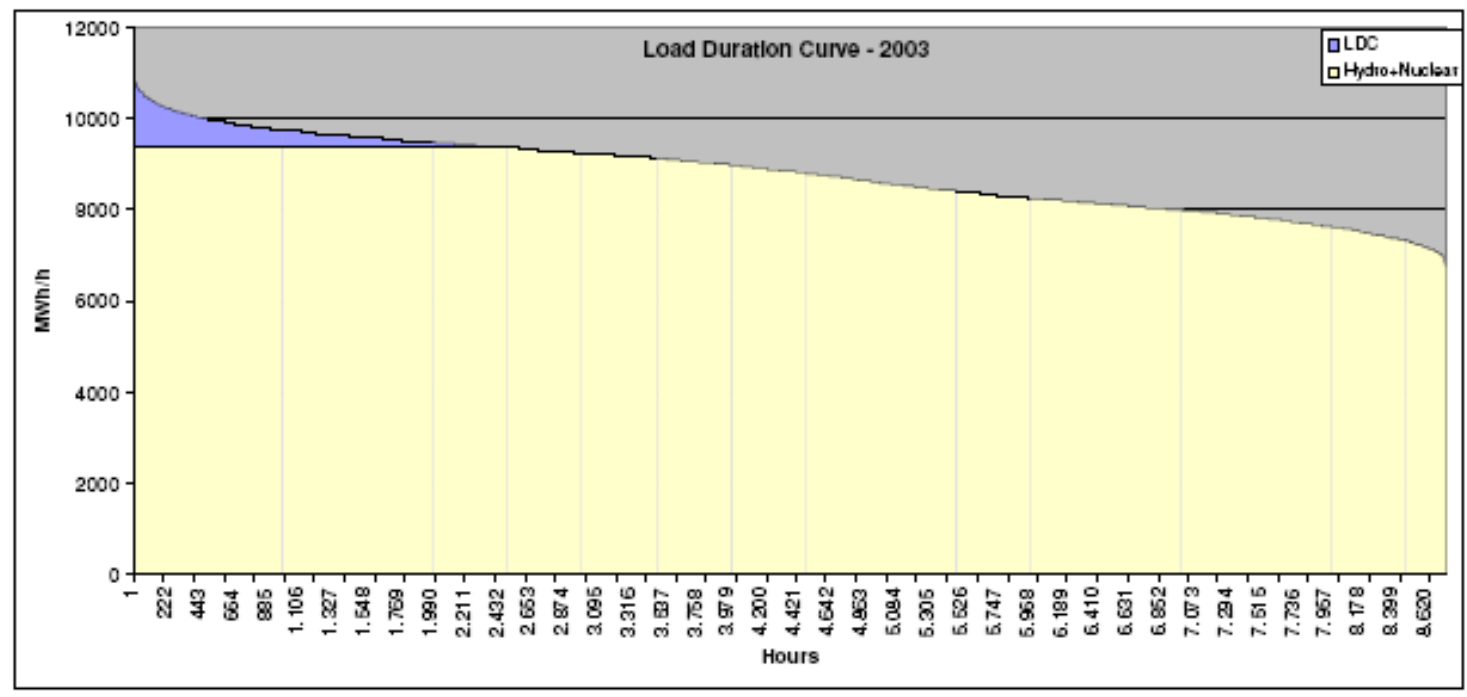

Figura B.3. Curva de duração de carga com participação por fonte geradora para o Subsistema do SIN - N/NE no ano de 2003. Fonte: (PDD, 2005)

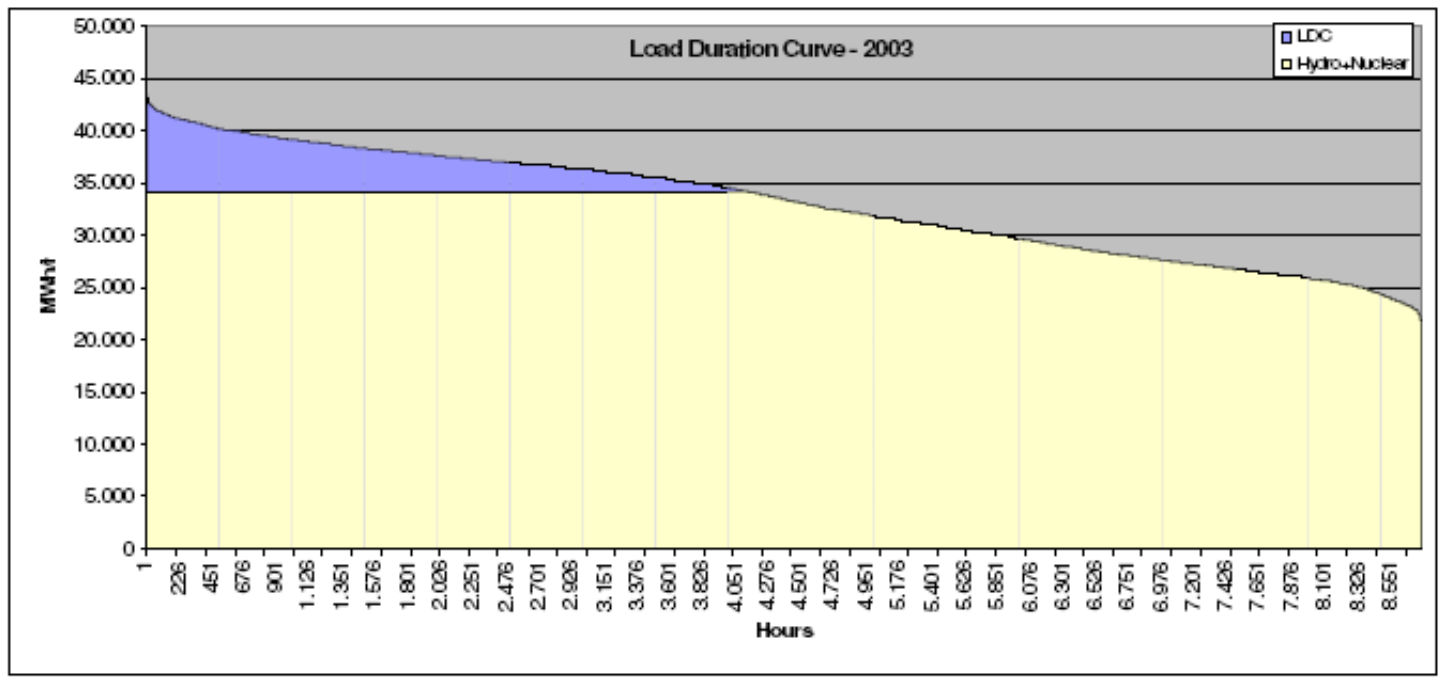

Figura B.4. Curva de duração de carga com participação por fonte geradora para o Subsistema do SIN - S/SE/CO no ano de 2003. Fonte: (PDD, 2005) 
Tabela B.1. Lambdas calculados a partir dos dados disponibilizados pelo ONS para os Blocos do SIN. Fonte: (PDD, 2005)

\begin{tabular}{cccc}
\hline \multicolumn{3}{c}{ Sistema Interligado Nacional } \\
\hline \multicolumn{2}{c}{ Bloco } & S/SE/CO & \multicolumn{3}{c}{ Bloco $N / N E$} \\
\hline Ano & Lambda & Ano & Lambda \\
\hline 2002 & 0,5053 & 2001 & 0,9046 \\
2003 & 0,5312 & 2002 & 0,939 \\
2004 & 0,5041 & 2003 & 0,7192 \\
\hline
\end{tabular}

\section{B.2.3. OM COM ANÁLISE DOS DADOS DO DESPACHO}

Este fator de emissão é definido como:

$$
E F_{\mathrm{OM}-\text { Análise dos dados de Despacho,y }}=\frac{E_{O M, y}}{E G_{y}} \quad \mathrm{tCO}_{2} / \mathrm{MWh} 5
$$

Onde o numerador e o denominador são caracterizados como:

$E_{O M, y}$ São as emissões (em $\left.\mathrm{tCO}_{2}\right)$ associadas com a $\mathrm{OM}$ e calculadas com:

$E G_{y}$ É a energia elétrica gerada no projeto (em MWh) no ano $y$. Este parâmetro deve ser medido diretamente de forma horária agrupada mensalmente sendo analisada a totalidade dos dados monitorados e, armazenado em meio eletrônico durante o período de concessão dos créditos e ao término do mesmo após dois anos. No caso de projetos de melhora na eficiência apenas os valores líquidos serão considerados (verificando os recibos de venda da energia entre os dois períodos - antes e depois da implementação).

Sendo $E_{O M, y}$ calculado da seguinte forma:

$E_{O M, y}=\sum_{h} E G_{h} \cdot E F_{D D, h} \quad \mathrm{tCO}_{2} \quad 6$

Definidos como:

$E G_{h} \quad$ É a geração no projeto a cada hora h. Este parâmetro deve ser medido diretamente de forma horária agrupada mensalmente sendo analisada a totalidade dos dados monitorados devendo ser armazenado em meio eletrônico durante o período de concessão dos créditos e, 
ao término do mesmo após dois anos. No caso de projetos de melhora na eficiência apenas os valores líquidos serão considerados (verificando os recibos de venda da energia).

$E F_{D D, h}$ É a ponderação média das emissões pela energia elétrica gerada $\mathrm{tCO}_{2} / \mathrm{MWh}$ pelo conjunto de plantas de geração $n$ que representam $10 \%$ dos despachos ordenados no sistema elétrico interligado durante a hora $h$.

$E F_{D D, h}=\frac{\sum_{i, n} F_{i, n, h} \cdot C O E F_{i, n}}{\sum_{n} G E N_{n, y}} \quad \mathrm{tCO}_{2} / \mathrm{MWh} 7$

É importante salientar que os parâmetros que compõem (7) e (8) têm o mesmo emprego que em (1) sendo alterado apenas o contexto onde elas estão inseridas

A determinação do conjunto de plantas $n$ obtém-se do centro responsável pelo despacho do país do projeto que, para o caso brasileiro é o Operador Nacional do Sistema Elétrico - ONS. As informações levantadas devem incluir a ordem e a potência despachada para cada planta de geração por hora $h$ que a planta esteja operando. Ordenando esta lista seleciona-se o grupo de empreendimentos que representam $10 \%$ do total de geração efetivamente despachada durante a hora especificada. Devendo ser incluído os montantes de eletricidade importada para a rede em estudo no mesmo período. Essas informações deverão ser armazenadas anualmente pelo período de concessão dos créditos e após o mesmo, por mais 2 anos, esteja ela no formato eletrônico ou impresso, desde que seja a informação do órgão oficialmente responsável.

\section{B.2.4. OM MÉDIO}

Este fator de emissão pode ser calculado utilizando a equação (1), considerando a taxa média de emissões de todas as plantas de geração, incluindo as fontes de baixo custo e as prioritárias para operação (excetuando as plantas que utilizam combustíveis fósseis). 


\section{B.3. ETAPA 02 - CÁLCULO DO FATOR DE EMISSÃO DE CONSTRUÇÃO (BM)}

Este fator de emissão é calculado como a ponderação das taxas de emissões na geração de eletricidade $\mathrm{tCO}_{2} / \mathrm{MWh}$ de uma amostra de $m$ fontes de geração presentes no sistema interligado.

$$
E F_{B M, y}=\frac{\sum_{i, m} F_{i, m, y} \cdot C O E F_{i, m}}{\sum_{m} G E N_{m, y}} \quad \mathrm{tCO}_{2} / \mathrm{MWh} 8
$$

Havendo duas opções para o cálculo do fator de emissão BM:

- Realizar o cálculo utilizando informações recentes disponíveis de plantas que existam e em operação para a amostra $m$ na época do envio do projeto. Essa amostra consiste:

a. Cinco plantas de geração que sejam recentemente construídas; ou,

b. Plantas de geração que sofreram alterações que compreendam cerca de $20 \%$ da geração do sistema e que tenham sido realizadas recentemente.

Dentre os itens (a) e (b) deve ser escolhido o que englobar a maior geração anual.

Para o primeiro período de créditos, o $\left({ }^{E F_{B M, y}}\right)$ deve ser atualizado anualmente após o ano de operação do projeto e as reduções nas emissões associadas. Para os períodos posteriores $\left(E F_{B M, y}\right)$ deverá ser calculado antecipadamente.

Expansão da capacidade de geração das plantas registradas como projetos dentro do escopo do Mecanismo de Desenvolvimento Limpo devem ser excluídos da amostra $m$. 


\section{B.4. ETAPA 03 - CÁLCULO DO FATOR DE EMISSÃO DA LINHA DE BASE PARA ELETRICIDADE}

Esse fator de emissão é uma média ponderada entre os fatores $\left({ }^{E F_{O M, y}}\right) \operatorname{com}$ o $\left({ }^{E F_{B M, y}}\right)$, conforme a fórmula a seguir:

$E F_{\text {Eletricidade }, y}=\omega_{O M} \cdot E F_{O M, y}+\omega_{B M} \cdot E F_{B M, y} \quad \mathrm{tCO}_{2} / \mathrm{MWh} 9$

Onde $\left(\omega_{O M}\right)$ e $\left(\omega_{B M}\right)$ por padrão são considerados como $50 \%$, isto é, 0,5 . Outras combinações no peso podem ser adotadas desde que justificadas e verificados pela Comissão Executiva do Mecanismo de Desenvolvimento Limpo, mantendo e considerando sempre que a soma dos pesos deverá resultar em $100 \%$, isto é, 1 .

Os valores adotados no projeto serão fixos durante o período de obtenção dos créditos e podem ser revisados na renovação do mesmo.

Para efeito de monitoramento, esse fator de emissão calculado deverá ser armazenado anualmente em meio eletrônico pelo período de concessão dos créditos e quando o mesmo findar deverá ser mantido por mais 2 anos. 


\section{ANEXO C - METODOLOGIA DO PROJETO ExternE - EXTERNALITIES OF ENERGY}

Este projeto procurou quantificar os custos externos da maioria das tecnologias de geração de eletricidade aplicadas na Europa visando quantificar as externalidades em cada sistema nacional de potência, além de auxiliar na elaboração de políticas para o setor energético. Os cenários foram compostos pelas tecnologias mais representativas no sistema energético de cada país considerando os possíveis desdobramentos desse sistema no longo prazo.

$\mathrm{Na}$ condução desse projeto, 20 sub-projetos de pesquisa foram conduzidos em 10 anos de atividades, envolvendo participantes de diversas universidades européias com um custo aproximado de 10 milhões de euros.

\section{C.1. METODOLOGIA DESENVOLVIDA PELO PROJETO ExternE}

A metodologia escolhida para avaliação dos custos externos é baseada no ciclo completo do combustível selecionado e foi elaborado pelos integrantes do Projeto ExternE. De forma geral, é uma metodologia bottom-up utilizando estimativas via cadeia de impactos. Após a definição da metodologia foi desenvolvida uma aplicação computacional conhecida como EcoSense, além de uma base de dados com informações específicas para cada um dos 15 países que participaram desta fase do projeto. Os resultados, estudos e metodologias foram publicados pela Comissão Européia num total de 10 volumes.

Basicamente, a definição das categorias de impacto e as externalidades são levantadas com uma estimativa dos efeitos e impactos da atividade, neste caso, geração de eletricidade. Em geral, os impactos são alocados com base na diferenciação entre cenários, isto é, os efeitos decorrentes sem a presença do empreendimento e com a presença do mesmo no local. Em seguida, ocorre o estudo visando monetizar os impactos a fim de definir um custo externo avaliando as incertezas inerentes às análises e, quando possível, apresentando análise de sensibilidade das variáveis mais atuantes do efeito estudado. 


\section{C.1.1. O MODELO COMPUTACIONAL}

Um aspecto interessante quanto ao modelo computacional EcoSense está relacionado à sua estrutura. Foi previsto no projeto que, devido às incertezas e informações incompletas em relação aos mecanismos biológicos, químicos e físicos, o software permita a integração de novas descobertas ao sistema. Como conseqüência, os módulos relativos aos cálculos foram desenhados de forma a interpretar o modelo a ser aplicado antes de realizar o cálculo, isto é, o modelo não é fixo. Para tanto, utiliza-se um banco de dados com as equações, as funções dose-resposta e valores monetários, entre outras informações.

A aplicação ${ }^{90}$ avalia os custos externos relacionados a:

- impactos ambientais, liberação de substâncias, efeitos físicos (calor, radiação e ruído) no meio ambiente (ar, solo e água);

- impactos decorrentes do Aquecimento Global, onde dois métodos são apresentados: um quantifica os danos estimados e o outro os custos evitados. Entretanto, devido à grande margem de incertezas e possíveis falhas ainda existentes no modelo, prefere-se trabalhar com a metodologia de custos evitados; e,

- acidentes, associados aos riscos sobre os bens públicos e pessoas externas aos empreendimentos.

O software considera mais de 14 tipos de poluentes, incluindo particulados, metais pesados e hidrocarbonetos, dioxinas, mas não considera os nuclídeos radioativos ${ }^{91}$. O programa obedece ao seguinte esquema conforme a figura:

\footnotetext{
${ }^{90}$ EcoSense

${ }^{91}$ estão relacionados com a operação das plantas nuclearese possuem tratamento diferenciado, baseado em levantamentos estatísticos ao invés do tratamento de modelagem dado aos demais poluentes.
} 


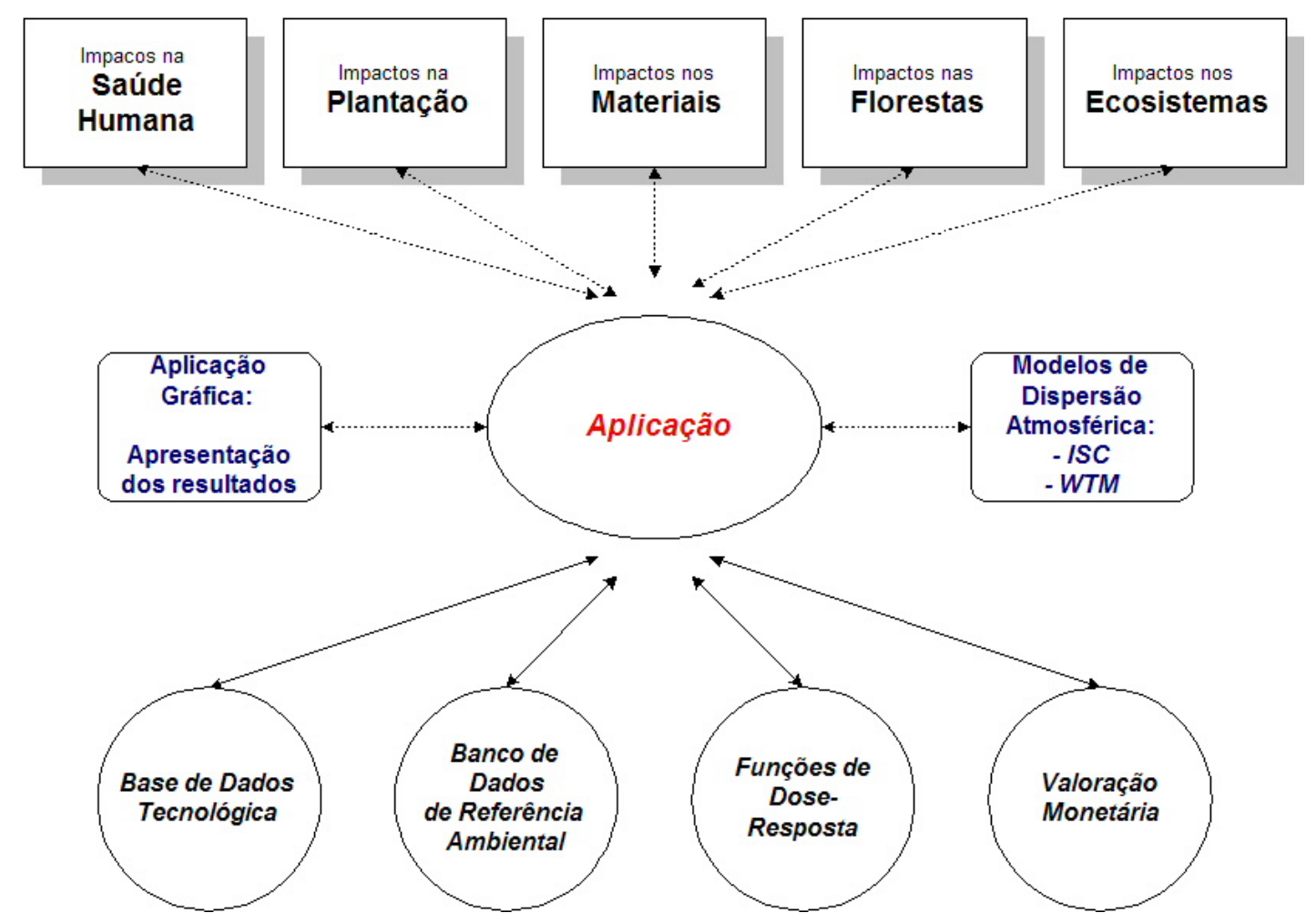

Figura C.1. Estrutura do modelo EcoSense. Fonte: (EC, 1999)

Os dados utilizados para alimentar o banco de informações são baseados nos modelos e padrões da União Européia sendo complementados com estatísticas de cada país. Alguns exemplos dos tipos de dados fornecidos são: inventário das emissões dos países participantes da UE; informações metereológicas; velocidade e direção do vento; precipitação; elevação do solo; população; construções, entre outros.

O modelo de avaliação dentro do EcoSense foi batizado como Impact Pathway Approach (IPA) que basicamente avalia a especificação e a tecnologia empregada pela planta de geração de eletricidade sob os aspectos dos efeitos físicos nos receptores (população, meio ambiente, edificações etc.), sendo avaliada em seguida a área de abrangência do efeito estudado. Num segundo momento, já tendo definida a região afetada, são aplicadas funções dose-resposta e modelos de exposição visando quantificar o impacto. Por último, ocorre a valoração do efeito externo. 


\section{C.1.2. A FUNÇÃO DOSE-RESPOSTA}

As funções de dose-resposta podem ser definidas pelo usuário por qualquer modelo matemático desejado. A função é armazenada num segundo momento como uma string ${ }^{92}$ no banco de informações que são interpretadas no momento da execução. Todas as funções doseresposta desenvolvidas pelos pesquisadores do projeto estão pré-armazenadas neste mesmo banco de dados.

\section{C.1.3. QUALIDADE DO AR E MODELOS DE DISPERSÃO}

Com relação aos modelos de dispersão e a qualidade do ar, destacam-se duas formas complementares cuja aplicação varia com a escala:

- local $l^{93}$, considerando uma dispersão gaussiana da pluma, isto é, a função de distribuição da concentração de emissões contínuas na atmosfera é considerada com a forma gaussiana. Procura-se com esse modelo avaliar o comportamento da pluma em pequenas distâncias (entre 10 a $50 \mathrm{~km}$ ), negligenciando reações químicas dentro do raio de avaliação. Deste modo, o modelo é suficiente para descrever os fenômenos de difusão turbulenta e mistura vertical entre as emissões e a atmosfera; e,

- regional ${ }^{94}$, com o aumento da distância há tanto uma distribuição vertical quanto horizontal da pluma devido à interação com a atmosfera fora da área de análise local, isto é, distâncias superiores a $50 \mathrm{~km}$ do ponto da emissão. No entanto, este modelo assume que os poluentes interagem na camada de mistura da atmosfera apenas verticalmente, mas, por outro lado, as reações químicas não são negligenciadas nesta escala.

\footnotetext{
92 tipo de dado que um campo do banco de dados pode armazenar. Esta categoria indica uma seqüência limitada de caracteres alfanuméricos

${ }^{93}$ Industrial Source Complex Short Term Model, version 2 - ISCST2

${ }^{94}$ Windrose Trajectoty Model - WTM
} 


\section{C.1.3. IMPACTOS NA SAÚDE}

Em relação à análise dos efeitos à saúde, as disfunções que foram tratadas nesse estudo ${ }^{95}$ estão relacionadas com o tipo de poluente ${ }^{96}$ e as funções de exposição-resposta. São os efeitos:

- da poluição atmosférica não cancerígena;

- cancerígenos:

○ devido às emissões de radionuclídeos;

- relacionados com dioxinas e traços de metais;

- de saúde ocupacional ${ }^{97}$; e,

- acidentes envolvendo uma grande quantidade de pessoas.

Adicionalmente, são apresentados valores de incerteza relativos à evidência epidemiológica, pois o levantamento dessas informações está calcado na avaliação da cadeia tornando possível uma análise de sensibilidade. Os resultados obtidos podem ser segmentados para as faixas etárias infantil, adulta e sênior. Os resultados têm certa imprecisão visto que cada pessoa tem um limite biológico próprio quando em contato com os poluentes e na obtenção dos resultados são utilizados valores médios para cada grupo exposto. Para este tipo de externalidade a valoração é feita tendo como referência a quantidade de anos perdidos na expectativa de vida da população.

As formas de exposição às emissões atmosféricas considerando a cadeia de impactos para saúde pública possuem três vias de contato:

- inalação e exposição externa devido à imersão dos poluentes no ar;

- exposição a deposições de poluentes no solo; e,

\footnotetext{
95 as especificidades de cada disfunção são tratadas com maior profundidade em (EC, 1999)

${ }^{96}$ o dióxido de enxofre e o monóxido de carbono foram negligenciados. O efeito do dióxido de nitrogênio é considerado apenas em análises de sensibilidade

97 por exemplo, acidentes do trabalho
} 
- ingestão de comida contaminada advinda da contaminação do solo.

Um dos resultados do ExternE é que os poluentes emitidos para o ar que forem ingeridos indiretamente possuem efeitos adversos na saúde de até duas ordens de magnitude superior ao efeito ocasionado pela inalação do mesmo.

A cadeia de impacto é discutida a seguir na figura abaixo:

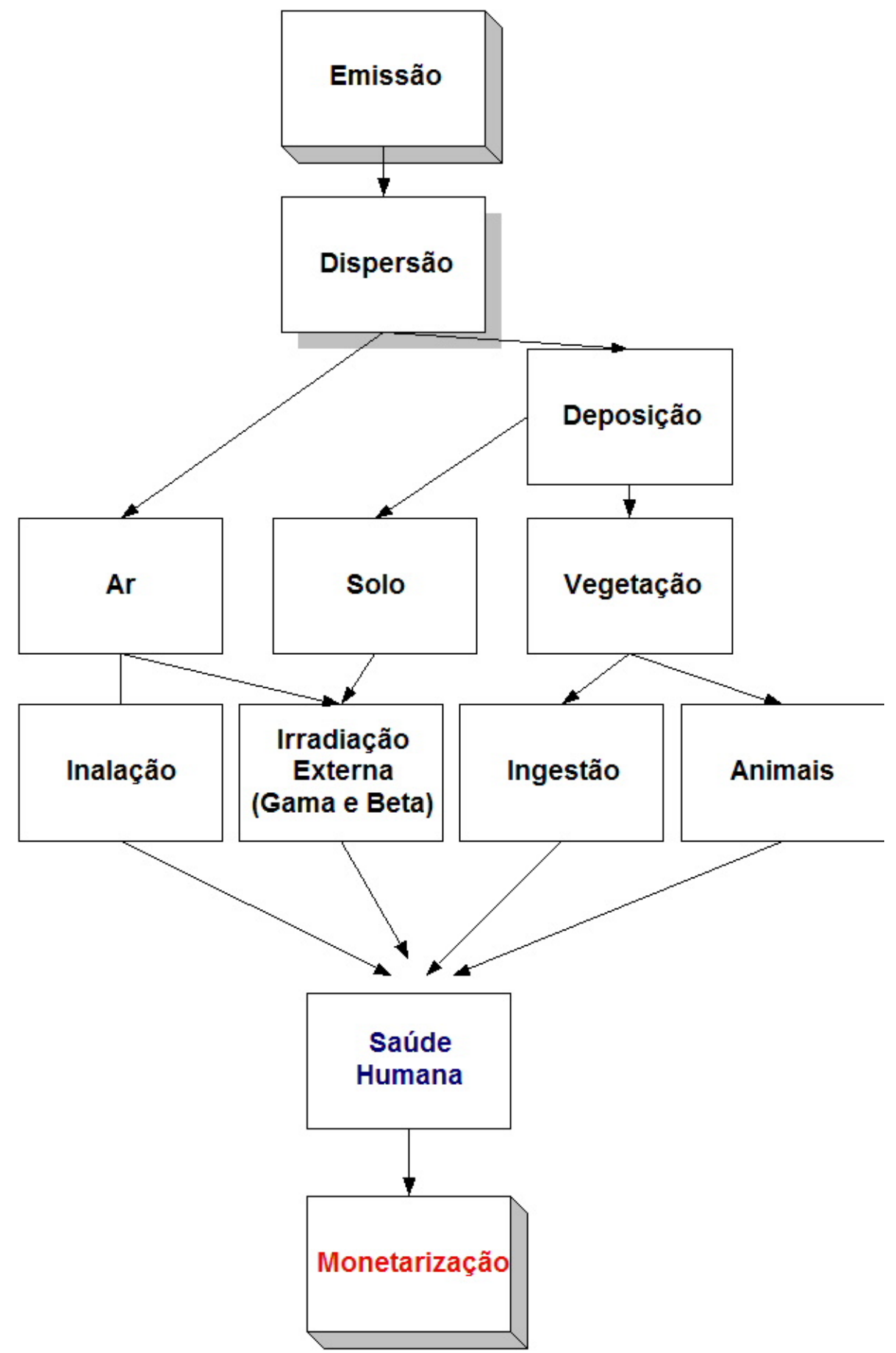

Figura C.2. Cadeia de impacto para emissões atmosféricas. Fonte: (EC, 1999) 


\section{C.1.4. IMPACTOS NOS MATERIAIS}

Os efeitos da poluição atmosférica nos materiais ${ }^{98}$ de prédios, esculturas e monumentos históricos são os exemplos mais conhecidos de externalidades relacionadas ao desgaste de materiais estando diretamente ligadas às ações de poluentes decorrentes da combustão dos derivados de petróleo. São necessários dados metereológicos, de umidade e o histórico da poluição atmosférica para sua quantificação. Devido à falta de informações e ao desconhecimento de outros mecanismos de dano apenas os efeitos relacionados com a corrosão serão avaliados.

Os seguintes materiais foram analisados para identificação das funções de dose-resposta:

- rochas;

- alvenaria;

- concreto;

- pinturas e materiais poliméricos; e,

- metais, tais como: zinco, aço galvanizado e alumínio.

A quantificação deste tipo de custo externo foi delineada pela freqüência de reparo, baseada nas perdas da espessura desses materiais e valorado como a disposição de evitar o dano incremental.

\section{C.1.5. IMPACTOS NO ECOSSISTEMA E FLORESTAS}

O ciclo de um combustível é capaz de afetar o ecossistema de várias formas. Para este projeto foram considerados os efeitos da poluição em plantações, florestas e as correspondentes variações na produtividade considerando os efeitos do $\mathrm{SO}_{2}, \mathrm{O}_{3}$, acidificação do solo, efeitos dos fertilizantes e deposição de nitrogênio. O efeito de acidificação dos lagos e rios e os

\footnotetext{
${ }^{98}$ por exemplo, corrosão, manchas etc.
} 
impactos relativos à mudança do clima nos ecossistemas não foram considerados por não haver dados suficientes para compor o modelo. Com a mesma justificativa, os efeitos externos em florestas não são quantificados.

\section{C.1.6. MUDANÇAS CLIMÁTICAS}

$\mathrm{Na}$ avaliação dos danos provenientes do aquecimento global, os seguintes gases foram considerados: $\mathrm{CO}_{2}, \mathrm{CH}_{4}, \mathrm{~N}_{2} \mathrm{O}$ e respectivos impactos na economia devido à alteração na temperatura e aumento do nível do mar utilizando cenários de demanda de energia, crescimento populacional e PIB.

\section{C.1.7. RESULTADOS OBTIDOS}

Baseado nos resultados, duas propostas de internalização foram estudadas:

- taxar pelos danos provocados pelo uso dos combustíveis; ou,

- subsidiar tecnologias limpas que evitem os custos externos sócio-ambientais.

Como a aplicação de taxas dentro da União Européia poderia provocar um aumento no preço da energia, em fevereiro de 2001, foi publicado o documento State Aid for Environmental Protection onde é oferecido um dispositivo de incentivo para novas plantas que utilizem fontes renováveis com um auxílio calculado com referência aos custos externos evitados. No entanto, este auxílio não poderá ultrapassar o valor de 5 Centavos Euro/kWh.

Além disso, os maiores fatores que integram os custos externos totais são referentes à saúde da população e a mudança do clima. Os gastos totais na geração de eletricidade na União Européia podem atingir uma faixa de 1 a $2 \%$ do produto interno bruto. Tanto na União Européia quanto na Inglaterra os altos valores foram encontrados para as plantas que utilizam combustíveis fósseis e os valores baixos para os baseados em fontes renováveis e nuclear. Da mesma forma, há uma diferenciação dos custos externos entre regiões urbanizadas e rurais. 
O estudo obteve os seguintes resultados por fonte energética:

- Carvão: é o tipo de tecnologia que apresenta os maiores impactos em relação às demais plantas. Impactos na saúde devido à elevada concentração de sulfatos seguido dos nitratos, ozônio e particulado;

- Gás Natural: para este energético, as emissões de óxido de nitrogênio contribuem para a maior parte para as externalidades encontradas. As emissões de particulados também são um fator considerável, porém são encontrados baixos índices de emissão de $\mathrm{SO}_{2}$;

- Óleos: neste energético as fontes de emissões mais significantes são: óxidos de nitrogênio, $\mathrm{SO}_{2}$ e particulado; e,

- Biomassa, basicamente os óxidos de nitrogênio e os particulados emitidos são as maiores fontes de externalidades.

\section{C.2. O PROJETO ExternE NO BRASIL}

Esta tentativa de implantar o projeto ExternE no Brasil teve como metas introduzir os estudos de externalidades das cadeias energéticas do país, alimentar com informações ambientais e tecnológicas o banco de dados da aplicação EcoSense e possibilitar a capacitação, o manejo e o desenvolvimento de módulos para o software de avaliação de custos externos no país.

Procurou-se incorporar nas características do código EcoSense as especificidades do Brasil e América Latina. O trabalho foi desenvolvido em conjunto pelo IPEN - Instituto de Pesquisas Energéticas e Nucleares, CNEN-SP - Comissão Nacional de Energia Nuclear e CDTN/CNEN-MG - Centro para o Desenvolvimento da Tecnologia Nuclear.

As pesquisas iniciaram-se em 1999, quando a CNEN e a IEA - International Energy Agency, estabeleceram um programa de cooperação técnica para utilizar a metodologia do Projeto ExternE. A ferramenta computacional para estimar o custo das externalidades em energia é o código EcoSense. Para este projeto, o código original foi adaptado para cobrir a região delimitada pela América Latina. 
Entretanto, a adaptação que o código EcoSense sofreu para ser usado no Brasil contém algumas imprecisões, pois essas bases de dados que estão conectadas ao programa são da versão européia do mesmo, que trazem dados metereológicos e de dispersão atmosférica referentes ao padrão europeu, que são diferentes do brasileiro. Assim, as análises feitas a partir deste programa podem trazer sérias imperfeições (Molnary et al, 1999). A criação de bases de dados metereológicos e de dispersão atmosférica adaptadas para a realidade brasileira são necessárias para que os resultados do programa sejam mais compatíveis com a realidade do Brasil.

O trabalho acabou sendo interrompido em 2000, quando o convênio ente a CNEN e a IEA encerrou-se, e não houve aporte de recursos financeiros que possibilitassem a continuação das pesquisas.

\section{C.3. NEW ELEMENTS FOR THE ASSESSMENT OF EXTERNAL COSTS FROM ENERGY TECHNOLOGIES - NEWEXT}

Partindo dos resultados obtidos no Projeto ExternE, a Comissão Européia iniciou um novo grupo de pesquisa conhecido como NEWEXT que visa estudar elementos adicionais para avaliar as externalidades, tais como:

- avaliação monetária do risco de mortalidade;

- os fenômenos de eutrofização e acidificação em ecossistemas e na biodiversidade;

- efeitos advindos dos danos em vários componentes do meio ambiente (ar, água, solo); e

- valoração dos custos externos envolvidos em acidentes na cadeia do combustível;

Atualmente o projeto se encontra aplicando as metodologias desenvolvidas aos novos membros da Comunidade Européia, bem como refinando e incluindo novas considerações nas análises. 
Outro aspecto que tem sido muito trabalhado por este projeto são as discussões em torno das formas de internalização, acessibilidade dos dados aos tomadores de decisão na área energética, competitividade frente ao mercado internacional, além das rotas tecnológicas que apresentem menores efeitos externos. 